\title{
CARACTERIZAÇÃO GENÉTICO-MOLECULAR DE LINHAGENS COM DUPLICAÇÃO CROMOSSÔMICA EM
}

Aspergillus nidulans

\section{ÁgATA Cristiane HUPPERT GIANCOLI}

Tese apresentada à Escola Superior de Agricultura "Luiz de Queiroz", Universidade de São Paulo, para obtenção do título de Doutor em Agronomia, Área de Concentração: Genética e Melhoramento de Plantas.

P I R A C I C A B A

Estado de São Paulo - Brasil

Junho - 2004 


\title{
CARACTERIZAÇÃO GENÉTICO-MOLECULAR DE LINHAGENS COM DUPLICAÇÃO CROMOSSÔMICA EM
}

\author{
Aspergillus nidulans
}

\section{ÁgAtA Cristiane HUPPERT Giancoli}

Bióloga

Orientador: Profa. Dra. ALINE APARECIDA PIZZIRANI-KLEINER

Tese apresentada à Escola Superior de Agricultura "Luiz de Queiroz", Universidade de São Paulo, para obtenção do título de Doutor em Agronomia, Área de Concentração: Genética e Melhoramento de Plantas.

PIR A C I C A B A

Estado de São Paulo - Brasil

Junho - 2004 
Dados Internacionais de Catalogação na Publicação (CIP) DIVISÃO DE BIBLIOTECA E DOCUMENTAÇÃO - ESALQ/USP

Giancoli, Ágata Crisitiane Huppert

Caracterização genético-molecular de linhagens com duplicação cromossômica em Aspergillus nidulans / Ágata Crisitiane Huppert Giancoli . - Piracicaba, 2004.

186 p. : il

Tese (doutorado) - - Escola Superior de Agricultura Luiz de Queiroz, 2004.

Bibliografia.

1. Aspergillus - Linhagens 2. Fungos filamentosos 3. Genética molecular 4. Instabilidade mitótica I. Título

CDD 589.24 
“... e, no entanto se move”.(Galileu Galillei)

"Um experimento conduzido em torno de meados da década de quarenta (século XX) me preparou para aceitar respostas inesperadas do genoma frente a situações de choque para as quais o genoma não está preparado para enfrentar de forma ordenada e programada".(Bárbara McClintock, abertura do discurso ao receber o Prêmio Nobel de Medicina, 8/12/1983). 
Dedico

\begin{abstract}
À memória de meu avô Anafräin Huppert,
Á minha mãe Ivone Huppert Giancoli, os meus irmãos Flaviana e Hermínio, meu querido sobrinho Gabriele ao meu amigo felino Jorge.
\end{abstract}

Ofereço

à Rodrigo Migotto Seraide 


\section{AGRADECIMENTOS}

A todos que direta ou indiretamente colaboraram para a realização desse trabalho quero agradecer e, em especial a:

Profa. Dra. Aline Aparecida Pizzirani-Kleiner, minha orientadora, por sua orientação, apoio e amizade durante meu desenvolvimento acadêmico.

Prof. Dr. João Lúcio de Azevedo, pelo apoio e amizade durante meu desenvolvimento acadêmico.

Dr. Fernando Gomes Barcellos, meu querido "irmão", pela grande amizade durante todos estes anos, pelo incentivo, apoio e convivência durante o período que estivemos cursando a pós-graduação.

Dr. Welington Luiz Araújo, pela grande cooperação, apoio e sugestões durante o desenvolvimento das pesquisas, e principalmente pela sua grande amizade e compreensão.

Prof. Dr. André Oliveira Souza Lima, pela amizade e pelos ensinamentos de bioinformática.

Profa. Dra. Margarida L. R. Aguiar-Perecin pela utilização de seu laboratório para a execução nas análises de microscopia de fluorescência.

Dr. Mateus Mondin pelo apóio na utilização do microscópio de fluorescência.

José Antônio da Silva (Zezo), grande e constante amigo, muito obrigado por sua colaboração tanto nos momentos bons como nos difíceis.

A Silvia C.M. Molina, pela ajuda na utilização do microscópio de fluorescência.

As minhas grandes amigas Mayra e Joelma, pelo apoio, incentivo e amizade constante. 
Aos meus queridos e inesquecíveis amigos do laboratório de Genética de Microrganismo os quais considero minha segunda família: Cristina Maki, Cristina Almeida, Adalgisa, Taís, Júlia, Carolina, Carol Almeida, Aline (Romã), Priscilla, Cláudia, Ana Carolina, Luciana, Beatriz, Fernanda, Manuela, Léia, Cecília, Sônia, Vivian, Heloise, Clara, Rodrigo, Fernando, Rudi, Ricardo, Paulo Lacava, Guilherme, Sérgio, Aldo, Kadu, Uirá.

A minha eterna amiga Maria Regina Priolli.

A Léia, pelos serviços prestados na secretaria da Pós-Graduação, pela amizade e agradável convivência.

Ao Corpo Docente do Departamento de Genética, os quais contribuíram de forma admirável para minha formação acadêmica.

A todos colegas do Curso de Pós-Graduação de Genética e Melhoramento, pela convivência, alegrias e esperanças compartilhadas.

A minha avó Ivone Kleiner Huppert

A Família Seraide, Sr. Carmelo, Sra. Carolina, Pablo e Patrícia, pela calorosa acolhida.

A Dimas e Gabriela, novos membros da minha família.

A CAPES pela bolsa de Doutorado concedida.

A Deus. 


\section{SUMÁRIO}

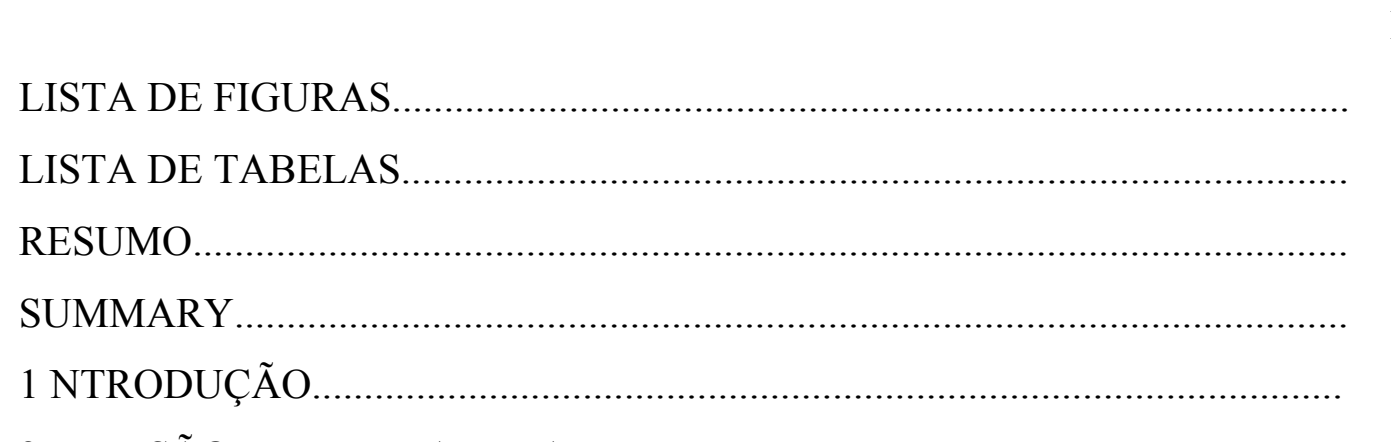

Página

xii

xvi

XVii

xviii

2 REVISÃO DE LITERATURA.................................................................. 3

$2.1 \mathrm{O}$ fungo filamentoso Aspergillus nidulans................................................. 3

2.1.1 Ciclo Vegetativo de Aspergillus nidulans................................................ 5

2.1.1.1 Germinação, Polarização e Desenvolvimento da hifa.............................. 5

2.1.1.2 Principais Mutantes para o Ciclo Celular e Migração Nuclear.................. 8

2.1.2 Aquisição da Competência...................................................................... 19

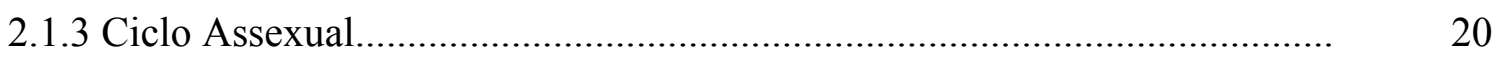

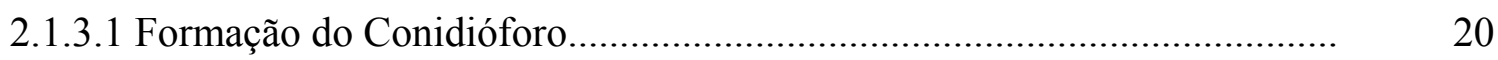

2.1.3.2 Principais Mutantes para a Conidiogênese............................................. 22

2.1.4 Interação entre Ciclo Celular, Migração Nuclear e Conidiogênese............. 30

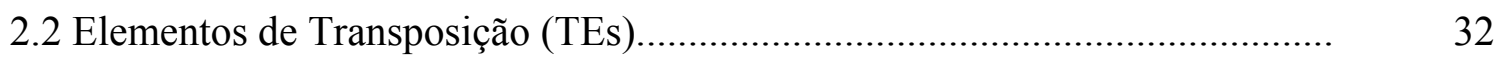

2.2.1 Estrutura dos Elementos de Transposição................................................... 33

2.2.2 Detecção de Elementos de Transposição.................................................. 39

2.2.3 Importância do estudo dos Elementos de Transposição em Fungos Filamentosos................................................................................... 40

2.2.4 Elementos de Transposição em Fungos Filamentosos...................................... 42

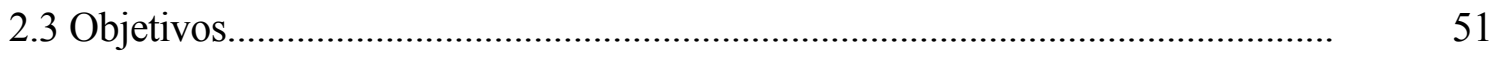


3 MATERIAL E MÉTODOS......................................................................... 53

3.1 Linhagens de Aspergillus nidulans utilizadas................................................. 53

3.2 Técnicas de Análise Genética........................................................................ 54

3.2.1 Obtenção de heterocários........................................................................... 54

3.2.2 Isolamento de diplóides.......................................................................... $\quad 55$

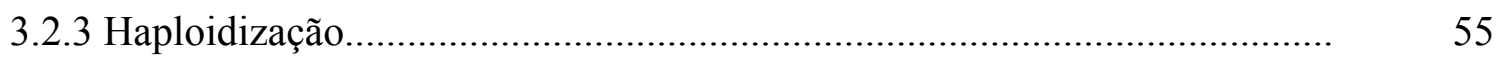

3.2.4 Análise Meiótica por meio Ciclo Sexual..................................................... 56

3.2.5 Meios de Cultura e Soluções..................................................................... 57

3.2.5.1 Meio Mínimo....................................................................................... 57

3.2.5.2 Meio Completo................................................................................ 57

3.2.5.3 Meio Completo líquido........................................................................ 58

3.2.5.4 Meio Mínimo líquido.............................................................................. 58

3.2.5.5 Meio Mínimo líquido acrescido de 4\% de Meio Completo........................ 58

3.2.5.6 Solução de vitaminas............................................................................. 58

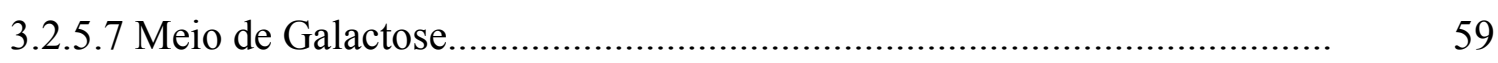

3.2.5.8 Meio de Acetato de Amônio..................................................................... 59

3.2.5.9 Solução de Tween 80............................................................................ 59

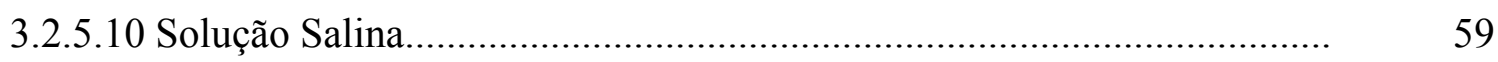

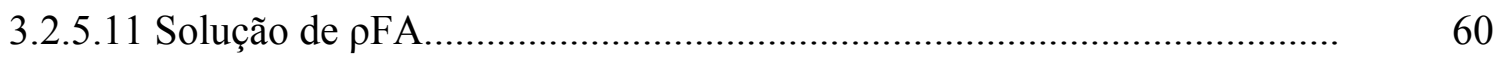

3.2.5.12 Solução de suplementos adicionais para o meio mínimo........................... $\quad 60$

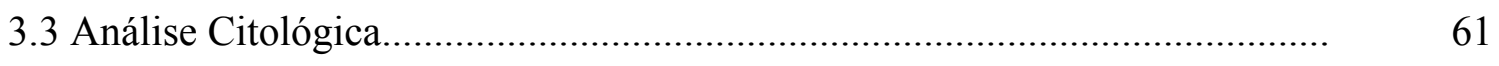

3.3.1 Coloração de Núcleo e Parede Celular com Corante Fluorescente............... 61

3.3.2 Soluções para Análise Citológica................................................................. 62

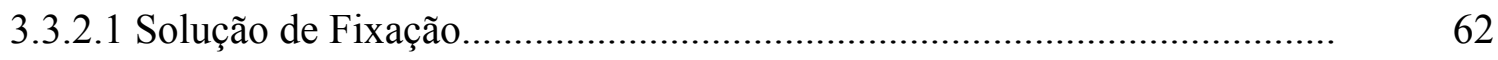

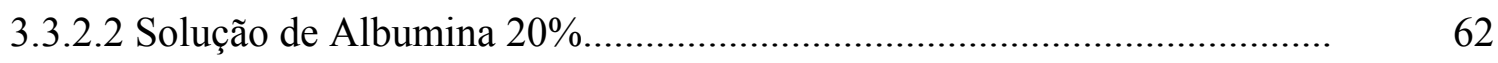

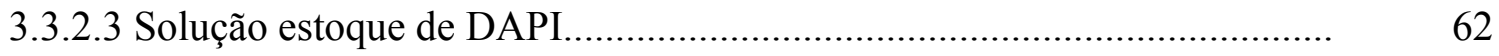

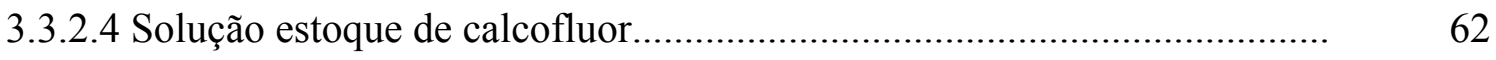

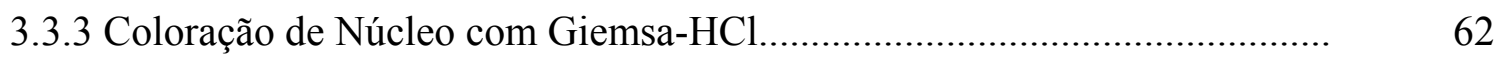

3.3.3.1 Tampão Fosfato 0,2 M pH 7,0...........................................................

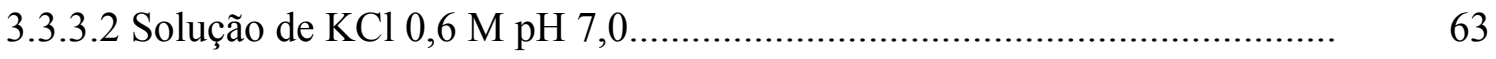




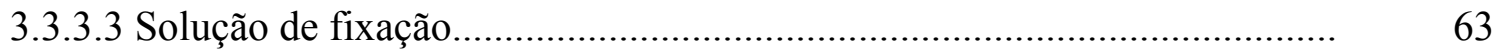

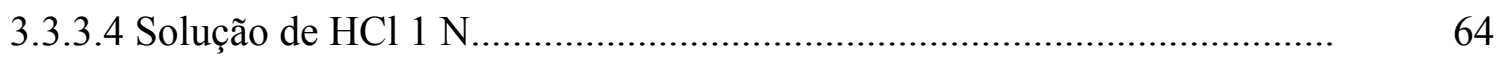

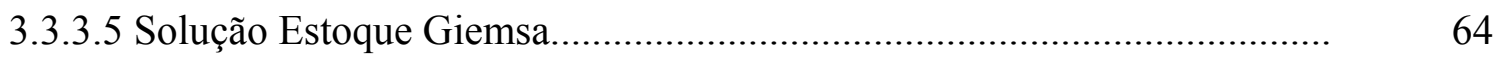

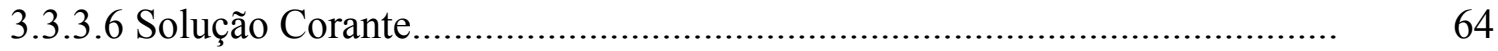

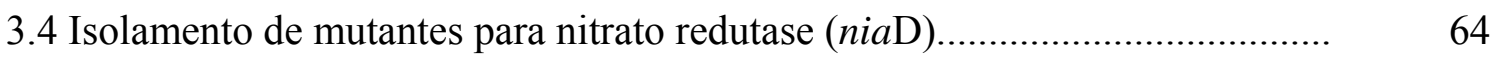

3.4.1 Metodologia para isolamento de mutantes de A. nidulans resistentes a Clorato de Potássio 0,3 M......................................................................... 64

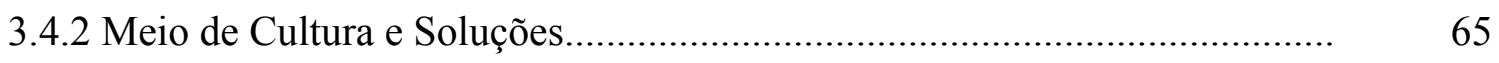

3.4.2.1 Meio Mínimo sem fonte de Nitrogênio...................................................... 65

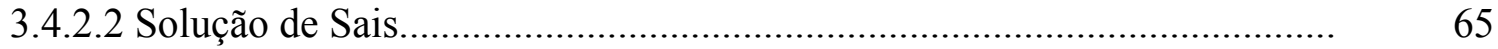

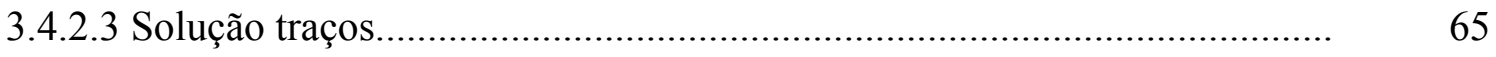

3.4.2.4 Meio de Cultura para isolamento de mutantes para nitrato redutase.......... 65

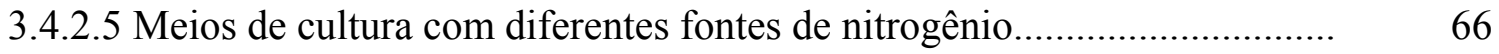

3.4.3 Isolamento de mutantes para nitrato redutase (niaD) pó meio do ciclo sexual de A. nidulans...................................................................... 66

3.4.3.1 Meio Mínimo com $10 \mathrm{mM}$ de Nitrito de sódio mais $0,45 \mathrm{M}$ de Clorato

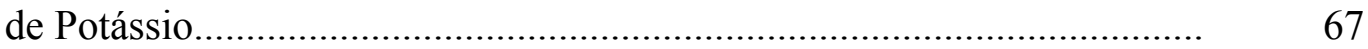

3.4.3.2 Meio Mínimo com $10 \mathrm{mM}$ de Tartarato e amônia mais 0,45 $\mathrm{M}$ de Clorato de Potássio.

3.4.3.3 Meio Mínimo com $10 \mathrm{mM}$ de Cloreto de amônia de sódio mais 0,45 $\mathrm{M}$ de Clorato de Potássio

3.4.3.4 Meio Mínimo com 0,7 mM de hipoxantina mais 0,45 $\mathrm{M}$ de Clorato de Potássio.

3.4.4 Teste de Reversão.

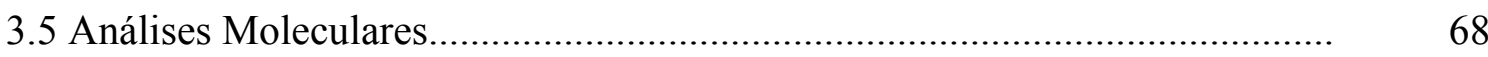

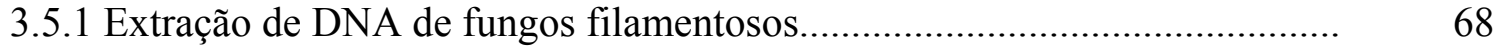

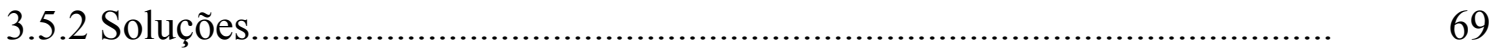

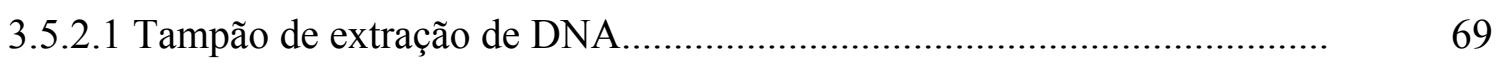

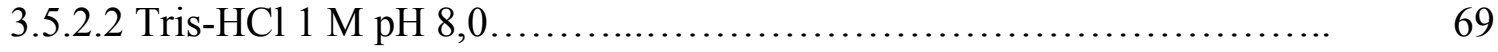

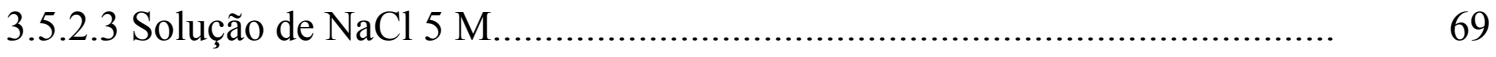


3.5.2.4 Ácido Etileno - Diamino - Tetracético (EDTA) 0,5 M pH 8,0................. 69

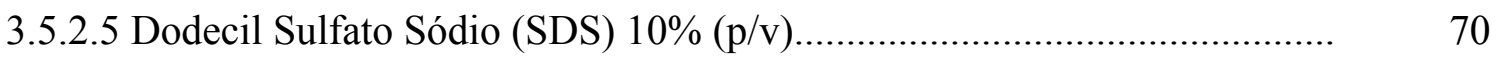

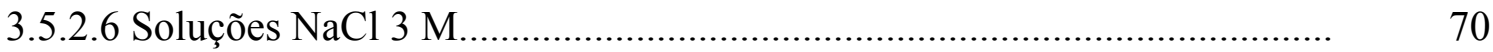

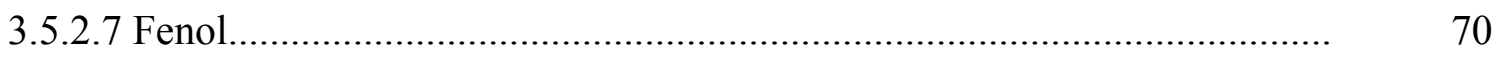

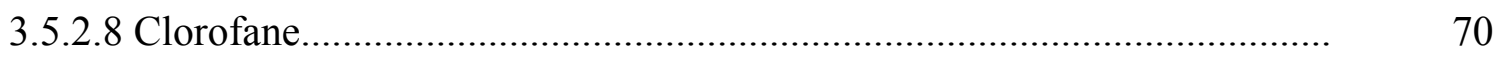

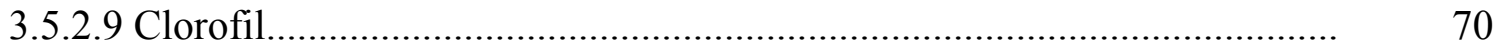

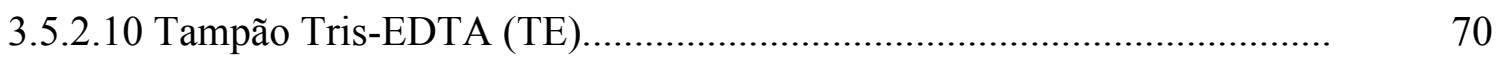

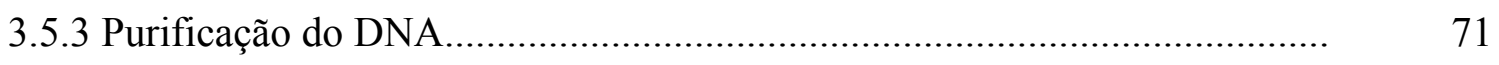

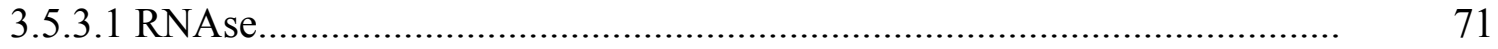

3.5.4 Construção dos Primers...................................................................... 71

3.5.4.1 Construção dos Primers para o gene niaD.............................................. 71

3.5.4.2 Construção dos Primers para amplificação do gene bristle ........................ 71

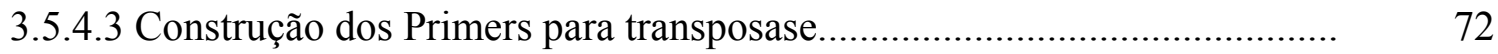

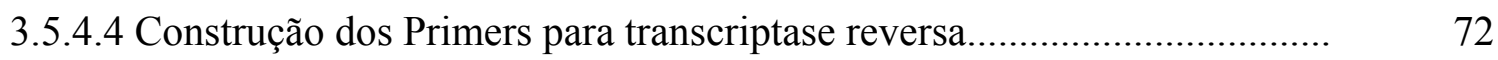

3.5.4.5 Construção dos primers para amplificação do transposons de Aspergillus nidulans MATE........................................................... $\quad 72$

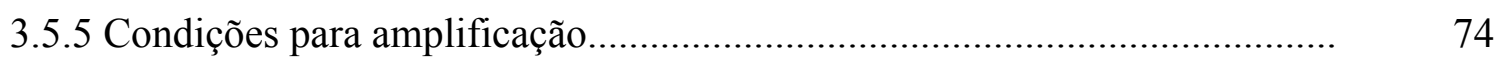

3.5.5.1 Tampão de corrida para eletroforese (6x concentrado)............................. 76

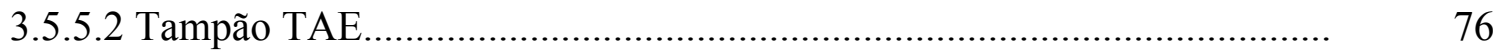

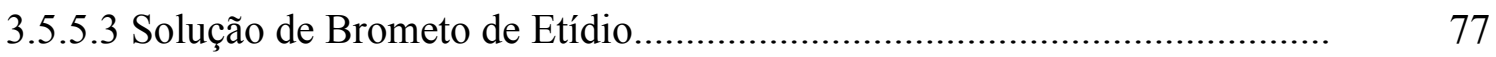

3.5.6 Purificação do produto de amplificação para 77 sequenciamento.

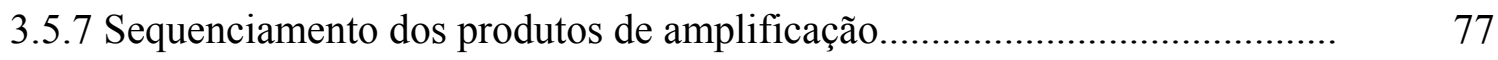

3.5.8 Purificação do produto de PCR para o sequenciamento................................. 78



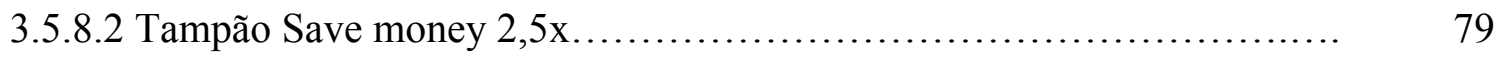

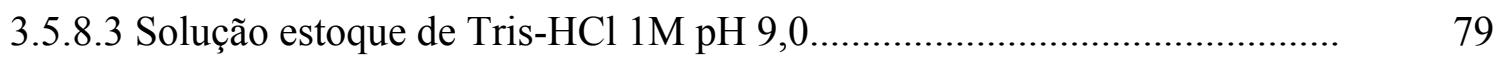

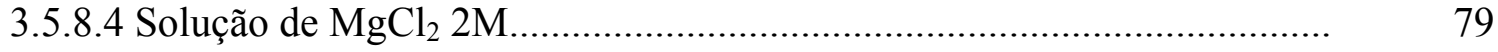

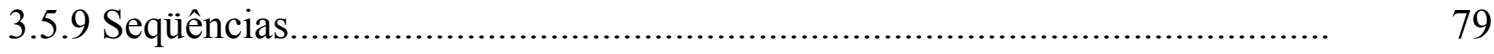


4. RESULTADOS E DISCUSSÃO ............................................................. 81

4.1 Análise Macroscópica das Colônias.............................................................. 81

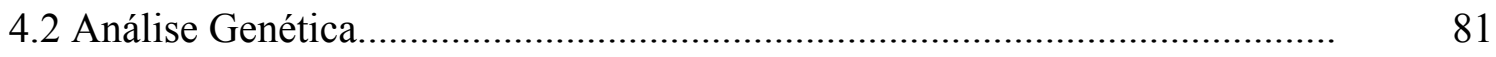



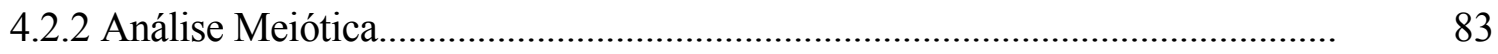

4.2.3 Análise Molecular do Variante Deteriorado V5.......................................... 88

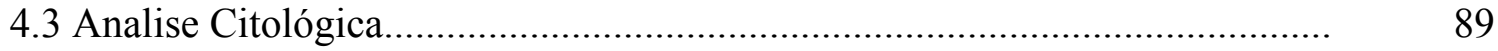

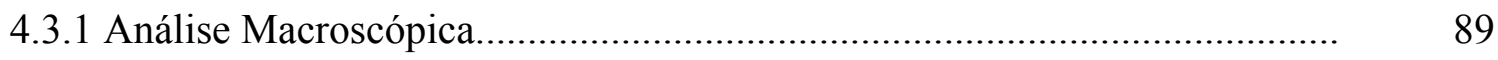

4.3.2 Germinação em Meio Completo líquido.................................................. 92

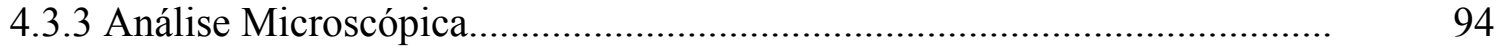

4.3.3.1 Análise das linhagens padrões........................................................ 95

4.3.3.2 Análise do Variante Deteriorado V101 ................................................ 100

4.3.3.3 Análise do Variante Deteriorado V102 ..................................................... 101

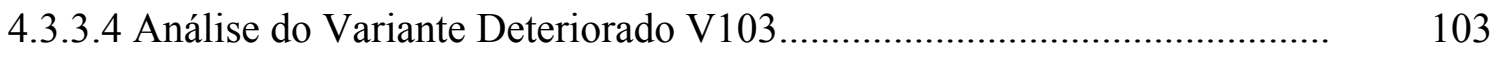

4.3.3.5 Análise do Variante Deteriorado V104................................................... 105

4.3.3.6 Análise do Variante Deteriorado V5 ................................................... 107

4.4 Isolamento de mutantes resistente ao clorato (niaD)................................... 113

4.4.1 Análise Molecular dos Mutantes niaD................................................... 117

4.4.2 Análise Molecular com primers niaD................................................... 118

4.4.3 Análise Molecular com primers para transposase e transcriptase reversa.... $\quad 122$

4.4.4 Análise Molecular com primers para Transposon MATE.......................... 123



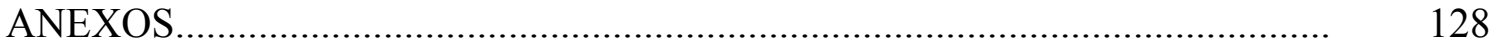

REFERÊNCIAS BIBLIOGRÁFICAS.......................................................... 143

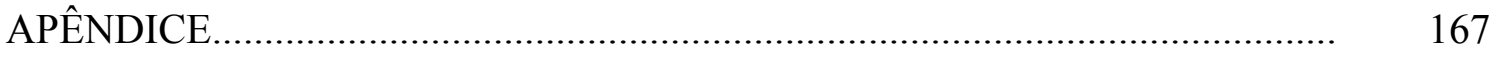




\section{LISTA DE FIGURAS}

Página

1 Conidióforo de Aspergillus nidulans. (h) hifa, (cp) célula pé, (ht) haste do conidióforo, (v) vesícula do conidióforo, (m) métula ou esterígma primário, (f) fiálide ou esterígma secundário, (c) conídios. Foto de microscopia eletrônica de varredura.

2 Esquema da divisão de Classes dos Elementos de Transposição........................ 35

3 Esquema de Elementos de Transposição em Fungos Filamentosos..................... 37

4 Estrutura do elemento Helitron e o mecanismo de "rolling-circle"

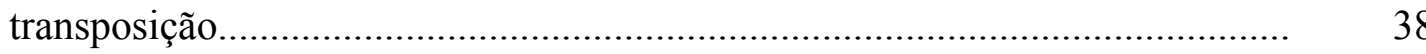

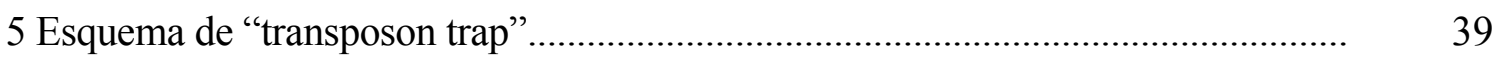

6 Fotos das linhagens padrões (a - c) e variantes deteriorados $(\mathrm{d}-\mathrm{h})$. a) MSE; b) A; c) PPY; d) V5; e) V101; f) V102; g) V103; h) V104. As linhagens foram crescidas por 7 dias a temperatura de $37^{\circ} \mathrm{C}$

7 Micrografia. (a) conidióforo da linhagem G0248 (b - c) conidióforo do variante deteriorado V5. Aumento de 1000x

8 PCR com primers BrlF - BrlR. (a) MSE, (b) V5, (c) branco. Fragmento com aproximadamente $1300 \mathrm{pb}$

9 Análise do crescimento das colônias padrões e variantes deteriorados em diferentes temperaturas $(\mathrm{cm})$. Linhagens padrões PPY, MSE e A; variantes deteriorados V5, V101, V102, V103 e V104.

10 Análise em porcentagem dos conídios germinados com 6 horas de crescimento em diferentes temperaturas. Linhagens padrões PPY, MSE e A; variantes deteriorados V5, V101, V102, V103 e V104. 
11 Germinação dos conídios das linhagens padrões temperatura de $37^{\circ} \mathrm{C}$. Linhagem MSE (a - i) 0, 2, 4, 6, 8, 12, 16, 20 e 32 horas respectivamente. Linhagem A (j - m) 4, 6, 8, 20 horas respectivamente. Linhagem PPY (n - p) 2, 16, 20 horas respectivamente. Figuras (a - f, i - k, n - o, aumento de 1000 x; Figuras g, h, 1, m, p, aumento de $400 \mathrm{x}$

12 Germinação dos conídios das linhagens padrões temperatura de $28^{\circ} \mathrm{C}(\mathrm{a}-\mathrm{h}) \mathrm{e}$ $42^{\circ} \mathrm{C}$ (i - k). Linhagem MSE (a - c) 4, 8 e 12 horas de desenvolvimento. Linhagem PPY (d - e) 8 e 12 horas. Linhagem A (f - h) 8 e 12 horas, Linhagem MSE (i) 12 horas de desenvolvimento. Linhagem PPY (j) 12 horas. Linhagem A (k) 12 horas. Aumento de 1000 $\mathrm{X}$

13 Variante Deteriorado V101. (a) conídio com o dobro do tamanho 4 horas; (b) conídio com tubo germinativo 8 horas; (c) conídio com extenso tubo germinativo não septado 12 horas; (d) conídio com tubo vegetativo e ramificações anormal não há evidências de septos 16 horas; (e, f) formação de conidióforos anormais 32 horas. A seta indica final de uma anáfase. Aumento $1000 \mathrm{x}$

14 Variante Deteriorado V101. (a - b) conídios com 6 e 8 horas, temperatura de $28^{\circ} \mathrm{C}$; (c) conídio com tubo germinativo 12 horas, temperatura de $42^{\circ} \mathrm{C}$. Aumento $1000 \mathrm{x}$

15 Variante Deteriorado V102. (a) conídio com 0 hora (b) conídio com início da formação do tubo germinativo 4 horas (c) conídio com extenso tubo germinativo 6 horas (d) conídio com tubo vegetativo anormal não há evidências de septos 12 horas; (e) presença de grande quantidade de células hülle, (f, g) formação de conidióforos anormais 32 horas, aumento $1000 x$

16 Variante Deteriorado V102. (a - b) conídios com 6 e 8 horas, temperatura de $28^{\circ} \mathrm{C}$; (c) conídio com tubo germinativo 6 horas, temperatura de $42^{\circ} \mathrm{C}$. Aumento 1000x.

17 Variante Deteriorado V103. (a) conídio com 0 hora (b) conídio com inicio da 
formação do tubo germinativo, 6 horas (c) conídio com extenso tubo germinativo septos com formação irregular, 12 horas (d) formação de hifas ramificadas, 20 horas; (e, f) formação de conidióforos anormais 32 horas, aumento $1000 \mathrm{x}$

18 Variante Deteriorado V103. (a - b) conídios com 6 e 8 horas, temperatura de $28^{\circ} \mathrm{C}$; (c - d) conídio com 6 e 8 horas, temperatura de $42^{\circ} \mathrm{C}$. Aumento $1000 x$

19 Variante Deteriorado V104. (a) conídio com 0 hora (b) conídios com o dobro do volume celular, 4 horas (c) conídio com tubo germinativo, 6 horas (d) conídios com tubo germinativo e septação irregular, 12 horas; (e) conídios com tubo germinativo e septação irregular, 16 horas; f) formação do micélio com septação anormal, 20 horas, aumento 1000x.

20 Variante Deteriorado V104. (a - b) conídios com 4 e 8 horas, temperatura de $28^{\circ} \mathrm{C}$; (c - d) conídio com 12 horas, temperatura de $42^{\circ} \mathrm{C}$. Aumento $1000 \mathrm{x}$

21 Variante Deteriorado V5. (a) conídio com 2 horas (b) conídios com o dobro do volume celular, 4 horas (c) conídio com tubo germinativo, 6 horas (d - e) conídios com tubo germinativo e ramificações, 8 - 12 horas; (f - h) hifas globosas, 20 horas; (i) haste do conidióforo segmentada e com estrutura globosa, 20 horas; (j - k) conidióforos anormais. Aumento $1000 \mathrm{x}$

22 Variante Deteriorado V5. (a - b) conídios com 8 e 12 horas, temperatura de $28^{\circ} \mathrm{C}$; (c) conídio com 12 horas, temperatura de $42^{\circ} \mathrm{C}$. Aumento 1000x

23 Número de núcleos nos segmentos hifais nas temperaturas de $28^{\circ} \mathrm{C}, 37^{\circ} \mathrm{C}$ e $42^{\circ} \mathrm{C}$ das linhagens MSE, PPY, A e V5.

24 Esquema da localização dos primers dentro do gene niaD (seqüências de ácidos nucléicos).

25 Esquema da localização dos primers dentro da seqüência de aminoácidos do gene niaD 
26 Primers niaDF2 - niaDR4. (1) marcador $1 \mathrm{~Kb}$, (2) MSE, (3) A, (4) G125, (5) Sx1, (6) Sx2, (7) Sx3, (8) Sx4, (9) Sx5, (10) Sx6, (11) Sx7, (12) Sx8, (13) Sx9, (14) Sx10, (15) Sx11, (16) Sx12, (17) Sx13, (18) Sx14, (19) Sx15, (20) Sx16, (21) Sx17, (22) Sx18, (23) Sx19, (24) Sx20, (25) Sx21, (26) Sx22, (27) $\mathrm{Sx} 23$

27 Primers niaDF2 - niaDR2. (1) marcador $1 \mathrm{~Kb}$, (2) MSE, (3) A, (4) G125, (5) Sx1, (6) Sx2, (7) Sx3, (8) Sx4, (9) Sx5, (10) Sx6, (11) Sx7, (12) Sx8, (13) Sx9, (14) Sx10, (15) Sx11, (16) Sx12, (17) Sx13, (18) Sx14, (19) Sx15, (20) Sx16, (21) Sx17, (22) Sx18, (23) Sx19, (24) Sx20, (25) Sx21, (26) Sx22, (27) Sx23, (28) branco.

28 Primers niaDCDSF - niaDCDSR. (1) marcador $1 \mathrm{~Kb}$, (2) MSE, (3) A, (4) G125, (5) Sx1, (6) Sx2, (7) Sx3, (8) Sx4, (9) Sx5, (10) Sx6, (11) Sx7, (12) Sx8, (13) Sx9, (14) Sx10, (15) Sx11, (16) Sx12, (17) Sx13, (18) Sx14, (19) Sx15, (20) Sx16, (21) Sx17, (22) Sx18, (23) Sx19, (24) Sx20, (25) Sx21, (26) Sx22, (27)Sx23, (28) branco.

29 Primers mateF - mateR. (1) marcador $1 \mathrm{~Kb}$, (2) MSE, (3) A, (4)Sx1, (5) Sx2, (6) Sx3, (7) Sx4, (8) Sx5, (9) Sx6, (10) Sx7, (11) Sx8, (12) Sx9, (13) Sx10, (14) Sx13, (15) Sx14, (16) Sx15, (17) Sx18, (18) Sx19, (19) Sx22, (20)

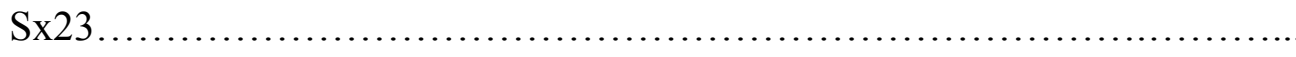
30 Primers mateF - mateR. (1) marcador $1 \mathrm{~Kb}$, (2) MSE, (3) A, (4)V5, (5) V101, (6) V102, (7) V103, (8) V104 


\section{LISTA DE TABELAS}

Página

1 Grupos de Ligação e Marcadores Genéticos das linhagens de A. nidulans utilizadas

2 Requisitos nutricionais adicionados ao meio mínimo durante as analises genéticas.

3 Quantidade de fontes de nitrogênio adicionada ao meio mínimo de cultura..

4 Primers utilizados.

5 Reação de PCR utilizada...

6 Reação de PCR para sequenciamento.

7 Seqüências depositadas no GeneBank - NCBI Home Page.

8 Descrição morfológica dos variantes deteriorados isolados da linhagem A de A. nidulans.

9 Teste de Auxotrofia dos Variantes deteriorados e das linhagens padrões.

10 Análise Mitótica. Localização dos determinantes de deterioração nos grupos de ligações

11 Resultado das Análises Meióticas.

12 Análise Mitótica V5 // G125 (biA 1 , niaD15).

13 Resultado das Análises Genéticas.

14 Assimilações de fontes de nitrogênio.

15 Mutantes para nitrato redutase isolados em diferentes fontes de nitrogênio.......

16 Teste de reversão de mutantes niaD. 


\title{
CARACTERIZAÇÃO GENÉTICO-MOLECULAR DE LINHAGENS COM DUPLICAÇÃO CROMOSSÔMICA EM
}

\section{Aspergillus nidulans}

\author{
Autora: ÁGATA CRISTIANE HUPPERT GIANCOLI \\ Orientadora: Profa. Dra. ALINE APARECIDA PIZZIRANI-KLEINER
}

\section{RESUMO}

A pesquisa de linhagens com duplicação cromossômica, como a linhagem A de Aspergillus nidulans, teve oseu início no final da década de 1970. Durante este período foram isolados da linhagem $\mathrm{A}$, diversos variantes deteriorados, que foram caracterizados genética e citologicamente. Neste trabalho de pesquisa, as analises genéticas demonstraram que os determinantes de deterioração ou segmentos de inserção de V5, V101, V102, V103 e V104 estão localizados nos grupos de ligação VIII, III, IV, VII e I respectivamente. As análises citogenéticas revelaram diversas alterações no ciclo celular e migração nucleares nas fases iniciais de desenvolvimento. A duplicação cromossômica da linhagem A e os variantes deteriorados foram investigados a nível molecular, por técnica de PCR. Os resultados mostraram que o segmento de inserção consiste de um provável Elemento de Transposição, denominado de MATE, o qual é característico do fungo Aspergillus nidulans. Os segmentos de inserção analisados apresentam características típicas de MATE, como o motivo "Spe" que é encontrado por toda seqüência dos Elementos MATE. 


\title{
CHARACTERIZATION GENETIC-MOLECULAR OF STRAINS WITH CHROMOSOMES DUPLICATION IN Aspergillus nidulans
}

\author{
Author: ÁGATA CRISTIANE HUPPERT GIANCOLI \\ Advisor: Profa. Dra. ALINE APARECIDA PIZZIRANI-KLEINER
}

SUMMARY

The research with chromosome duplication strains, as strain A of Aspergillus nidulans, began during the 70's, with isolation of several deteriorates variants of strain A and characterization by genetic and cytological analysis. In this work the genetic analysis has demonstrated that the deterioration determinant or insertion sequence in V5, V101, V102, V103 and V104 deteriorates variants are located in the linkages groups VIII, III, IV, VII and I, respectively. The cytological analyses have demonstrated changes in cellular cycle and nuclear migration in initial phases of development. The chromosome duplication of strain A and the deteriorated variants were investigated by PCR with designed primers to mobile elements, what have resulted in the identification of the transposable element MATE, mainly by great similarity with "Spe" motif sequence that is described as essential in activity of these elements. 


\section{INTRODUÇÃO}

Desde 1980, com o desenvolvimento de técnicas moleculares, houve um significativo avanço nos conhecimentos da regulação do ciclo celular, migração nuclear, desenvolvimento e diferenciação de diversos organismos multicelulares.

O fungo filamentoso Aspergillus nidulans é considerado modelo genético para diversos estudos, principalmente os estudos relacionados com ciclo celular, migração nuclear e desenvolvimento. Seu ciclo de vida é marcado por quatro eventos importantes: a germinação do conídio uninucleado, seguido de um período de crescimento vegetativo com a proliferação da hifa multinucleada, nesta fase as células adquirem competência, desencadeando os processo de reprodução assexual com a formação dos conidióforos, seguido pela reprodução sexual com a formação dos cleistotécios.

Os estudos referentes à mitose e migração nuclear em A. nidulans iniciaram com trabalhos do Dr. Ron Morris (Morris, 1976, 1995), o qual identificaram diversos mutantes com variações nos padrões de divisão, distribuição e migração nucleares. Paralelamente o Dr. John Clutterbuck iniciou os estudos gênicos da Conidiogênese (Clutterbuck, 1969). Essas duas linhas de pesquisa caminharam separadamente até os trabalhos de Mirabito \& Osmani (1994) e Ye et al. (1999) que demonstraram a correlação entre ciclo celular, migração nuclear e conidiogênese. A partir destes estudos ficou demonstrando que os eventos no desenvolvimento de $A$. nidulans são regulados em cascata, isto é, um evento é geneticamente dependente do outro para a entrada e regulação das etapas do ciclo de vida de A. nidulans. 
Os estudos genéticos realizados pelo Dr. Morris e pelo Dr. Clutterbuck basearam em mutantes obtidos por mutagênicos físicos e ou químicos. Nga \& Roper (1968a, b) e Azevedo \& Roper (1970) estudando linhagens de A. nidulans com duplicação cromossômica, verificaram que estas eram instáveis e produziam setores espontaneamente. Os setores poderiam ser melhorados (perda do segmento duplicado) ou deteriorados (segmento duplicado se transpõem para um dos oitos cromossomos de A. nidulans). Estudos realizados por diversos autores sob orientação do Dr. João Lúcio de Azevedo e da Dra. Aline A. Pizzirani-Kleiner demonstraram que o determinante de deterioração da linhagem A de A. nidulans (duplicação no cromossomo I, translocada para o II) "salta" pelos oito cromossomos de A. nidulans, produzido alterações no ciclo celular, desorganização na migração nuclear e alterações morfológicas na formação dos conidióforos. Esse sistema de instabilidade foi considerado muito semelhante aos elementos de transposição de milho, bactérias e drosófilas, sugerindo que a instabilidade genética que produz os setores deteriorados possa estar relacionada com os Elementos de Transposição.

Os elementos de transposição têm sido descritos amplamente em fungos filamentosos, como Fusarium sp, Aspergillus niger, Magnaporthe grisea, Neurospora crassa entre muitos outros. O trabalho de Nishimura et al. (2000), foi considerado o ponto de partida para o desenvolvimento deste trabalho de pesquisa. Estes autores descreveram no fungo Magnaporthe grisea, uma inserção do retrotransposon, o "MGL". A inserção do retrotransposon provocou alterações morfológicas na conidiogênese, por meio desta mutação, o gene para o desenvolvimento do conidióforo foi isolado e seqüenciado, apresentando alta homologia com o gene medusa (med) de A. nidulans, que gera alterações no conidióforo. Esta evidência aumentou as suspeitas que os setores deteriorados gerados pela a linhagem A de A. nidulans, pudessem ser um caso típico de elementos de transposição. 


\section{REVISÃO DE LITERATURA}

Dentro da linha de pesquisa proposta pelo trabalho, a revisão de literatura abordará dois assuntos distintos: o primeiro consiste de uma breve discussão sobre a Genética do Desenvolvimento do fungo filamentoso Aspergillus nidulans, cujo texto pretende copilar e analisar algumas informações disponíveis sobre os genes e proteínas envolvidos no desenvolvimento e diferenciação celular, o segundo consiste de uma breve discussão sobre os Elementos de Transposição (TEs), este texto pretende copilar e analisar algumas informações sobre os Elementos de Transposição (TEs) quanto sua classificação, sua presença e importância para o desenvolvimento científico em alguns fungos filamentosos.

\subsection{O fungo filamentoso Aspergillus nidulans}

O fungo filamentoso Aspergillus nidulans foi descrito por Eidam (1883, apud Pontecorvo et al., 1953). O estudo genético de $A$. nidulans teve êxito com pesquisas realizadas por Guido Pontecorvo, na década de 50 (Pontecorvo et al., 1953), levando esse microrganismo a consagrar-se como modelo biológico para estudos acadêmicos e aplicados.

As vantagens desse fungo para pesquisas consistem: na presença dos ciclos

sexual, assexual e parassexual (Pontecorvo, 1952; Clutterbuck, 1997), ciclo de vida curto, ser haplóide e homotálico, onde o ciclo sexual se completa sem necessidade de cruzamento entre linhagens sexualmente definidas, além de ser facilmente cultivado em meio de cultura definido a temperatura de $37^{\circ} \mathrm{C}$. 
Atualmente o mapa genético de A. nidulans é bastante estudado sendo possível mapear novos genes com precisão. Com o avanço da Genética Molecular, foi confirmado que $A$. nidulans possui oito cromossomos, por meio da técnica de separação de cromossomos por eletroforese de campo pulsado ("pulsed field gel electrophoresis") (Brody \& Carbon, 1989). Além disso, o mapa físico dos cromossomos de A. nidulans foi obtido baseado em dois bancos de cosmídios ordenados (pWee e pLorist) (Xiong et al., 1996). O genoma de A. nidulans está completamente seqüenciado e pode ser acessado pelo site http://www-genome.wi.mit.edu/annotation/fungi/aspergillus/. Com o banco de dados completo é possível, por exemplo, um melhor estudo de correlação entre mapa físico e genético, sendo útil para a clonagem dos genes que não podem ser estudados pelo método tradicional de complementação da mutação, utilizando banco genômico. A correlação entre mapas genéticos e seqüências de DNA contidas nos cosmídios conhecidos tem tornado a técnica "caminhando pelo cromossomo" ("chromosome walking") viável para a clonagem dos genes que apresentam fenótipos sutis (Hamer, 1997).

Várias classes de mutantes foram isoladas no decorrer dos anos, entre elas mutantes auxotróficos, mutantes para vias metabólicas, mutantes resistentes a diversas drogas e mutantes morfológicos. Esta última classe de mutantes pode ser subdividida em

mutantes para o crescimento e ciclo celular (Morris, 1976), mutante para aquisição da competência (Axelrod, 1972) e para a morfogênese do conidióforo (Clutterbuck, 1969). Estas três subdivisões podem ser consideradas como o estudo da Genética do Desenvolvimento.

O estudo da genética do desenvolvimento é extremamente complexo envolvendo diversos processos morfogenéticos que exigem refinado processo de regulação. Cada tecido apresenta peculiaridades no seu desenvolvimento espacial e temporal durante as sucessivas mitoses. Além disso, ocorre restrita relação entre os ciclos de multiplicação celular e os processos de diferenciação celular, nos quais uma quantidade enorme de genes interage.

Neste aspecto, o fungo filamentoso A. nidulans é um organismo modelo para o estudo da Genética do Desenvolvimento, devido a características como: ciclo de 
vida rápido, haploidia, presença de poucos tipos celulares distintos, mas com função bem diferenciada, além de uma morfogênese bem definida, possibilidade de sincronismo na conidiogênese, tornando viável o isolamento e a análise de compostos bioquímicos específicos. (Miller, 1990; Morpurgo, 1994).

O fungo A. nidulans apresenta seu ciclo de vida dividido em três fases:

a. Ciclo vegetativo;

b. Ciclo Assexual ou conidiogênese;

c. Ciclo Sexual ou Ascoporogênese.

Entre os ciclos de vida ocorre uma estreita relação. Em condições normais, primeiramente ocorre o desenvolvimento vegetativo, após ocorre o início da conidiogênese, que acarreta diminuição do desenvolvimento vegetativo para o amadurecimento do conidióforo, seguido pela diferenciação do cleistotécio (Adams et al., 1998).

\subsubsection{Ciclo Vegetativo de Aspergillus nidulans}

\subsubsection{Germinação, Polarização e Desenvolvimento da hifa}

O desenvolvimento do ciclo vegetativo pode ocorrer por meio de fragmentos de hifas, esporos sexuais e assexuais. Inicialmente ocorre o aumento do volume do esporo, seguido de sucessivas divisões mitóticas, originando o tubo germinativo (Harris, 1997a; Harris \& Hofmann, 1999; Harris, 2001) e estabelecendo o desenvolvimento vegetativo. O próximo processo é a aquisição da competência, acarretando a entrada do ciclo assexual, e quando este se completa, o fungo realiza o ciclo sexual (Axelrod et al., 1973; Timberlake, 1990; Timberlake \& Clutterbuck, 1994; Miller et al., 1985; Miller, 1990; Adams et al., 1998).

A primeira parte deste desenvolvimento tem início com o conídio, estrutura reprodutiva do ciclo assexual de $A$. nidulans. O conídio é capaz de manter a dormência por um vasto período de tempo sem perder a viabilidade, ocorrendo uma situação favorável, como temperatura, umidade e nutrientes, o conídio é capaz de germinar e reproduzir uma colônia com as mesmas propriedades daquela que the deu origem (Timberlake \& Clutterbuck, 1994). 
O primeiro passo para germinação é a incorporação de água, fazendo que ocorra expansão do conídio e aumento da adesão em seu substrato. O início da germinação do conídio ocorre pelo reconhecimento da fonte de carbono (preferencialmente glicose) (Osherov \& May, 2000), que ativa todo o mecanismo RAS desencadeando o processo MAPK e promovendo todo o desenvolvimento do conídio (germinação, desenvolvimento micelial, divisão e migração nuclear) (Osherov \& May, 2001). No período de aproximadamente 4 horas ocorre a primeira divisão mitótica, sendo o tempo necessário para a quebra completa da dormência. Após 8 horas, o conteúdo citoplasmático aumenta em 10 vezes e o conteúdo de DNA aumenta em 8 vezes, ou seja, 3 divisões nucleares se completam sincronicamente (Fiddy \& Trinci, 1976). A partir da terceira divisão mitótica ocorre perda gradual da sincronização da divisão celular (Rosenberg \& Kessel, 1967).

Além disto, ocorrem alterações morfogenéticas, com a formação do tubo germinativo ao mesmo tempo em que ocorre a segunda divisão mitótica. $\mathrm{O}$ tubo germinativo apresenta desenvolvimento apical, estabelecimento um eixo de crescimento polarizado na ponta do tubo germinativo, fazendo com que a hifa cresça nesta direção pela deposição de parede celular (Gooday, 1983; Fiddy \& Trinci, 1976). Com as divisões mitóticas dos núcleos mais próximos do ápice ocorre formação periódica de septos. Os septos delimitam células com 2 a 10 núcleos e proporcionam a passagem de organelas e núcleos entre as células (Morris, 1976). Após o desenvolvimento do primeiro tubo germinativo, um segundo tubo é emitido em orientação oposta ao primeiro. Deste modo, em meio de cultura sólida, as hifas ramificam-se e crescem de forma subapical, formando uma colônia com crescimento radial (Pontecorvo et al., 1953; Morris et al., 1995).

O processo de deposição da parede celular é muito importante, pois se a parede celular não for corretamente formada há perdas do crescimento polarizado (McGoldrick et al., 1995). Doonan (1992) removeu por processo enzimático a parede celular, levando a formação de protoplastos esféricos e perda do crescimento polarizado, mas com uma nova deposição de parede celular o eixo polarizado volta a se estabelecer. Várias tentativas foram feitas para isolar mutantes que modificassem especificamente a polaridade do crescimento da hifa. A grande parte dos mutantes isolados afetam 
indiretamente a polarização, alterando a composição da parede celular e a estabilidade osmótica, isto ocorre por interferência direta no processo de divisão nuclear, como se pode observar no gene da calmodulina que afeta a divisão nuclear e, conseqüentemente, a polarização (Rasmussen et al., 1990).

Após a germinação do conídio uninucleado, ocorrem eventos que revelam uma coordenação entre mitose e citocinese (Harris et al., 1994).

Clutterbuck (1970a, b e 1994) e Fiddy \& Trinci (1976) observaram que depois da formação do tubo vegetativo há três séries de divisões mitóticas, originando oito núcleos que serão distribuídos por toda a extensão do tubo germinativo, paralelo a este processo ocorre à formação de um septo, que deixa pelo menos um núcleo dentro do conídio em desenvolvimento.

Experimentos realizados com mutantes termossensíveis para a divisão, migração nuclear e septação (Morris, 1976; Harris et al., 1994; Wolkow et al., 1996), demonstraram que para ocorrer a septação é necessário que um volume celular determinado seja alcançado, e isto só ocorre após, pelo menos, uma divisão mitótica. Estes dados demonstram a existência de algum inibidor da septação, que está presente em altas concentrações nos conídios, e o aumento do volume celular dilui o inibidor até o ponto em que não seja mais capaz de inibir a septação, conseqüentemente, a citocinese ocorre conjuntamente com a terceira divisão mitótica.

À medida que a hifa se expande na região apical, os núcleos que ficam nos compartimentos distais entram em dormência, isto é, não ocorre divisão mitótica. Porém os núcleos presentes nas pontas das hifas (cerca de 40) são mitoticamente ativos, continuando a dividir-se de modo semi-sincrônico e fazendo parte dos compartimentos septados (Rosenberg \& Kessel, 1967). Os núcleos nos compartimentos distais, em número variável de dois a dez, eventualmente, podem voltar a se dividir para formar as ramificações laterais da hifa, mas primeiro é necessário que se estabeleça um pólo de crescimento. Nem todos os compartimentos podem ser ativados para se ramificarem, e desconhece-se o sinal que determina qual será o compartimento selecionado (Harris \& Hofmann, 1999a). Dynesen \& Nielsen (2003) demonstraram que as ramificações são coordenadas pelo crescimento das hifas em mitose, isto é, para estabelecer a ramificação 
do micélio é necessário à relação entre a progressão do ciclo celular e a migração nuclear. A partir do momento em que o tubo germinativo se ramifica, as pontas da hifa deixam de ser o único sítio de crescimento polarizado e, então, o micélio passa a ter vários pontos de crescimento ativo, e a colônia vai adquirindo o seu aspecto circular quando crescida em meio de cultura sólido. (Harris \& Kraus, 1998).

\subsubsection{Principais Mutantes para o Ciclo Celular e Migração Nuclear}

Os estudos de mutantes para a regulação do ciclo celular e migração nuclear tiveram início com os experimentos de Morris (1976), sendo isolado uma série de mutantes termossensíveis relacionados a diversos aspectos do ciclo celular de $A$. nidulans (Osmani \& Mirabito, 2004).

\section{a Mutantes para desenvolvimento e septação das hifas}

Em fungos filamentosos o tubo germinativo cresce por extensão apical, o qual é caracterizado pela adição de nova parede celular no ápice da hifa (Wessel, 1986; Xiang \& Morris, 1999). O desenvolvimento do ápice da hifa ocorre em relação ao alto gradiente de cálcio (Regalado, 1998) e pH (Robson et al., 1996).

Os primeiros mutantes termossensíveis sep ("septation deficient") foram isolados por Morris (1976). A análise do mutante sepB3 mostrou a incapacidade das células continuarem o crescimento além da terceira divisão nuclear, morrendo logo em seguida, justamente no momento da citocinese. Durante as primeiras divisões nucleares é possível observar um atraso transitório da fase $\mathrm{M}$ da mitose, sendo que os núcleos apresentam forma características de aneuplóides. O gene sep foi clonado por Harris \& Hamer (1995) e o produto gênico apresentou homologia com a proteína CTF4 de Saccharomyces cerevisiae, que está intimamente relacionada com o metabolismo do DNA cromossômico. Os mesmos autores sugerem que o funcionamento incorreto de sep $\mathrm{B}$ pode levar a um acúmulo de algum tipo específico de dano cromossomal que não permite que as células completem a citocinese.

Harris \& Kraus (1998) confirmaram esta hipótese após experimentos realizados com doses subletais de hidroxiuréia e diepoxioctano, os quais levam à 
perturbações do metabolismo do DNA cromossômico, levando a um bloqueio semelhante ao observado no mutante sepB.

Harris et al. (1997b) realizaram estudos com o mutante para septação, sepA, que apresenta incapacidade de formar septo e possui padrão anômalo de ramificação da hifa e dos conidióforos durante o crescimento em temperatura restritiva $\left(42^{\circ} \mathrm{C}\right)$. Este mutante também apresenta um aumento no diâmetro da hifa, em ambas temperaturas (restritiva e permissiva). Os autores sugerem que quando o mutante cresce por um determinado tempo sob temperatura restritiva é incapaz de depor o septo, porém, quando a colônia é transferida para a temperatura permissiva os septos são rapidamente formados nas posições corretas. Na temperatura restritiva, o mutante é incapaz de formar o anel contrátil de actina na região aonde o septo vai ser deposto. A clonagem e caracterização do gene sepA, demonstraram que a proteína codificada pertence à família FH1/2, que possuem membros conhecidos em $S$. cerevisiae (bni1), Schizosaccharomyces pombe (cdc12) e Drosophila diaphanous.

Estudos moleculares tem revelado vários mutantes como suo ("suollen cells") (suoA, suoB, suoC, suoD e suoF) que atuam na correta polarização e migração nuclear nas hifas. Os genes suoC, suoD e suoF são requeridos para estabilizar a polaridade da hifa em desenvolvimento, enquanto que suoA é requerido para manter a polarização, isto demonstra que o estabelecimento e a constância da polaridade consistem em eventos geneticamente separados, sendo necessário um outro sinal para a extensão apical da hifa (Momany et al., 1999). Um destes sinais é a enzima N-Myristoyl transferase (NMTs), codificada por swoF (Shaw et al., 2002).

RHOA consiste de uma proteína envolvida no crescimento, ramificação e síntese da parede celular em A. nidulans. RHOA é homologa a RHO1 pertencente à família das GTPase que estão envolvidas na estabilização da polaridade e deposição da parede celular de S. cerevisiae. O gene clonado rhoA (Rho GTPase homologue") (Guest et al., 2004) apresenta agrupamento anormal na síntese da parede celular durante a ramificação do micélio.

Kaminskyj \& Hamer (1998) identificaram cinco locos para a morfogênese da hifa, hypA - hypE ("Abnormal hyphal morphology"), por meio de 
estudos de mutantes temperatura-sensível. Estas linhagens "hypercellular" apresentam morfologia aberrante, defeitos durante a morfogênese em temperatura restritiva (mas não são letais). As análises do fenótipo hyp sugerem que esta mutação promove a limitação do crescimento apical das células basais, isto é ocasionado aparentemente pela proteína HYPA que regula o trafico de endomembranas dentro da hifa (Kaminskyj, 2000; Shi et al., 2004).

Os genes sepA, hypA, podB, podC e podD ("Polarity defective"), são responsáveis por estabilizarem e manterem a polaridade da hifa (Harris et al., 1999a, b). Os genes sepA, hypA e podB são requeridos para múltiplos aspectos da morfogênese da hifa, já os genes sepA e podB são necessários para a organização do citoesqueleto. Em contraste, os genes podC e podD codificam uma proteína que aparentemente é requerida para o estabelecimento da polaridade da hifa durante a germinação do esporo. Estas evidências indicam que a integridade na formação do citoesqueleto de actina é necessária para o desenvolvimento normal do tubo germinativo. A caracterização molecular destes genes poderá esclarecer muitos aspectos sobre a citocinese, crescimento e migração nuclear na hifa.

\section{b Mutantes para a progressão do Ciclo Celular}

O ciclo celular é estabelecido por eventos básicos como: replicação do DNA cromossômico, a duplicação dos centríolos e formação das fibras do fuso mitótico. Esses eventos são altamente conservados em fungos e em todos eucariotos (animais e vegetais) (Morris et al., 1989; Morris \& Enos, 1992; Doonan, 1992; Nasmyth, 1996; Lew \& Kornbluth, 1996; Osmani \& Ye, 1996). Partindo da importância que o ciclo celular apresenta para a sobrevivência dos seres vivos, alguns pesquisadores iniciaram na década de 1970 o estudo da genética e bioquímica de mutantes que afetassem a mitose em organismos simples. Entre estes organismos se destacaram $S$. cerevisiae (Hartwell, 1974), S. pombe (Nurse, 1975) e A. nidulans (Morris, 1976). Desta forma, um grande número de genes relacionados ao controle do ciclo celular foi descoberto em animais e vegetais, graças ao conhecimento adquirido sobre a mitose em fungos (Hartwell \& Kastan, 1994). 
Bergen \& Morris (1983) descreveram a cinética de divisão nuclear em $A$. nidulans, estabelecendo que o ciclo celular ocorre durante a germinação do conídio, levando em torno de 75 - 120 minutos, dependendo da condição de crescimento. Na temperatura de $37^{\circ} \mathrm{C}$ a fase $\mathrm{M}$ é muito rápida, em torno de 5 minutos. G2 leva cerca de 30 minutos, S 25 minutos e G1 em torno de 15 minutos.

Um dos primeiros eventos que ocorre durante o ciclo de divisão celular é a duplicação da região organizadora do fuso mitótico (SPB "spindle pole body"). Esta duplicação ocorre durante a intérfase, precisamente durante a fase $\mathrm{S}$ do ciclo celular. Durante a metáfase os dois SPB formados migram para lados opostos tendo entre si um arranjo de microtúbulos, é nesta fase que o nucléolo torna-se menos distinto e desaparece. As imagens geradas por microscopia eletrônica sugerem que em fungos, apesar da membrana nuclear não desaparecer, ela se torna menos densa (Doonan, 1992).

$\mathrm{O}$ estudo da regulação celular em $A$. nidulans teve início com Morris (1976), partindo do isolamento de mutantes termossensíveis. Foram isolados mutantes bim ("Blocked in mitosis") e nim ("Never in mitosis"), este isolamento foi realizado com base no aspecto adquirido pelo núcleo quando corados com corantes com afinidade por ácidos nucléicos. Os mutantes nim possuem núcleos que aparentam estar sempre em interfase, isto é, a cromatina corada nas bordas e na região central descorada, corresponde ao nucléolo. Os mutantes bim foram assim classificados uma vez que seus núcleos apresentam um aspecto mitótico, ou seja, sempre condensado, como um pequeno ponto luminoso no interior da hifa (Morris, 1976).

A partir de estudos genéticos e bioquímicos, comprovou-se que os componentes regulatórios da mitose são conservados sendo possível estudá-los em $A$. nidulans. Os estudos têm se direcionado, principalmente, para uma classe de proteínas denominadas de "quinase dependente de ciclina" (cdk). Estas proteínas são as chaves para a replicação do DNA, iniciação da mitose, formação do complexo promotor da anáfase e citocinese (Lew \& Kornbluth, 1996; Nasmyth, 1996).

A clonagem de $n i m \mathrm{X}^{\mathrm{p} 34}$ possibilitou a caracterização em A. nidulans de umas das principais proteínas quinase, a qual estabelece o momento que o ciclo celular deve ultrapassar as barreiras G1/S e G2/M (Osmani et al., 1994). O gene nim $^{\mathrm{p} 34}$ faz parte 
de um complexo denominado de "cdk" ("cicline dependent kinase"), que para ser ativado deve estar ligado a um ciclina ( $n i m \mathrm{E}^{\text {cdc13 }}$ ). Mesmo que o complexo cdk seja formado, ele só será ativado, levando a progressão do ciclo celular quando a tirosina-15 da proteína p34 for desfosforilada por ação de uma proteína fosfatase codificada pelo gene nim $\mathrm{T}^{\text {cdc25 }}$ (O'Connell et al., 1992). Em A. nidulans só uma ciclina é conhecida, $n i m E^{\text {ciclina-B }}$, mas é provável que p34 associe-se a outros parceiros para promover as transições entre G1/S e G2/M (Osmani \& Ye, 1996). Para que a anáfase se complete, é necessário que haja quebra do complexo cdk, por meio da degradação da ciclina-B. Acredita-se que o complexo promotor da anáfase, ou ciclossomo seja responsável pela ubiquitinação da ciclina-B, caracterizando esta proteína como alvo de proteólise. (Osmani \& Ye, 1996; Wu et al., 1998).

NIMT não é a única fosfatase envolvida na progressão do ciclo celular em A. nidulans, o gene bim também codifica uma fosfatase específica da mitose, a inativação da mesma impede que as células deixem os estágios mais tardios da mitose. A seqüência de aminoácidos de BIMG mostrou homologia com uma proteína fosfatase (PP1) de mamíferos e de S. cerevisiae, as quais são essenciais para o sucesso da mitose (Doonan et al., 1991).

Osmani et al. (1987) clonaram nimA, o qual é fundador de uma família gênica encontrada desde leveduras até mamíferos. Este gene codifica uma proteína quinase do tipo Serina/Treonina. A princípio foi estabelecido que nimA funciona especificamente na progressão entre as fases G2 e M, sua atividade fosforilativa, bem como o acúmulo de seu mRNA, começou a elevar-se em G1 e S e apresenta seu pico em G2, ao contrário de p34 que possui níveis constantes tanto de seu mRNA quando da proteína durante todo ciclo celular. Durante a mitose os níveis de nimA começam a decair, e para que haja citocinese ela tem que ser abolida. As análises citológicas dos mutantes nimA demonstraram que durante o crescimento na temperatura restrita não há desorganização dos microtúbulos citoplasmáticos, não há condensação da cromatina e também não há formação do fuso mitótico. Portanto, a atividade da proteína NIMA é requerida para iniciar todos os aspectos da divisão nuclear (Pu \& Osmani, 1995). 
Outro complexo que regula a progressão do ciclo celular é designado de APC/C (complexo promotor da anáfase/ciclossomo). É composto por pelo menos oito polipeptídeos, dos quais dois são bem conhecidos bimA e bimE (O’Donnell et al., 1991). Ambos apresentam bloqueio para a terminação da fase $\mathrm{M}$ do ciclo celular, permanecendo com os núcleos condensados indefinidamente quando em temperatura restritiva. A mutação bim $^{\mathrm{APC} 3}$ é capaz de superar parcialmente o bloqueio imposto pela mutação em nimA, sendo que o duplo mutante é capaz de realizar a condensação da cromatina e organizar as fibras do fuso. Estes resultados indicam que nimA e bimA agem em conjunto, direta ou indiretamente, ocasionando a passagem por G2, o que é um resultado inesperado, uma vez que se acreditava que o complexo APC/C tivesse função apenas a partir da metáfase, finalizando a mitose (Lies et al., 1998).

O mutante bimD6 foi clonado por Denison et al. (1993), este mutante é sensível a altas temperaturas e apresenta dificuldade de ligação entre o cromossomo e o fuso mitótico, resultando na perda do cromossomo. Holt \& May (1996) identificaram sete supressores extragênicos de bimD6, que foram denominados de $\operatorname{sudA}$, sudB, sudC, sudD ("Suppressor of bim"). Anaya et al. (1998) isolaram a mutação sudD, determinando que seu transcrito SUDD é membro da família SMC de proteínas topoisomerases II atuando na condensação e segregação cromossômica de leveduras, $A$. nidulans e mamíferos, aumentando a proporção de perda cromossômica através de não disjunção (Holt \& May, 1996). Um aspecto de SUDD consiste em sua alta concentração de serina e treonina (11\%) sendo que este transcrito pode ser uma proteína quinase. Como a condensação cromossômica consiste de um evento regulado pelo ciclo celular, possivelmente a função de SUDD esteja relacionada com a regulação através da fosforilação, sendo necessário, mais estudos para comprovar este processo.

Outros genes fazem parte dos componentes estruturais da mitose, os quais foram isolados a partir de mutantes, como é o caso do gene benA ("Benlate resistence") que foi isolado a partir de mutante resistente à substância anti-microtúbulos benomil (Dekker \& Davidse, 1975). Os genes para a constituição da $\alpha$-tubulina, tubA ("Alphatubulin") que é componente dos microtúbulos presentes durante o crescimento vegetativo e tubB que desempenha funções durante a meiose (Doshi et al., 1991; Kirk \& 
Morris, 1991). Outro gene identificado por Oakley \& Oakley (1989) foi da $\gamma$-tubulina. Este gene está localizado na região organizadora do centríolo, não sendo um componente do microtúbulo, mas é requerido para iniciar a polimerização dos microtúbulos (Oakley et al., 1990).

Outro gene que pode ser descrito como mutante para a progressão do ciclo celular, é o gene bnc ("ㅁinucleate"), que afeta todos os estágios do ciclo de vida do fungo A. nidulans. A mutação do gene bncA estimula a rápida saída da fase $\mathrm{G} 1$, impedindo a germinação do conídio, eleva o índice mitótico do cromossomo (CMI) promove mitoses desordenadas em hifas velhas, densidade e distribuição anormal dos núcleos e morfogênese anormal durante a germinação e desenvolvimento dos esterígmas. Este mutante produz uma alta freqüência de conídios heterocários, os quais podem ser formados pelo movimento nuclear incorreto e, finalmente, estes mutantes são hipersensíveis a drogas anti-microtubulos. Estas observações sugerem que o gene bncA seja fundamental para a regulação do ciclo celular ou que seja requerido para o funcionamento dos microtúbulos (Pascon, 1998; Pascon et al., 2001). A mutação bncA apresenta fenótipo muito semelhante aos mutantes que afetam a duplicação do ciclo celular, como os mutantes bim (Morris, 1976; Enos \& Morris, 1990; O’Donnell et al. 1991). Pascon et al., (2001) analisaram o fenótipo desta mutação durante a germinação e formação do conidióforo. Os autores sugerem que bncA codifica um componente essencial, o qual é requerido para a segregação cromossômica e para o movimento ou posicionamento nuclear. A segregação cromossômica pode sofrer uma anormal organização ou orientação do fuso, levando a distribuição incorreta do núcleo durante a divisão celular em hifa, já a alteração na formação do fuso contribui para a quebra cromossômica, levando ao aumento da instabilidade (Pizzirani-Kleiner \& Azevedo, 1986a, b; Pascon et al., 2001). O posicionamento nuclear é muito importante para a vesícula do conidióforo, a qual possui um grande número de núcleos que estão alinhados no ápice das vesículas para poderem migrar para as métulas em desenvolvimento (Fischer \& Timberlake, 1995), mutantes similares ao gene bncA foram observados em $S$. cereviseae, o gene CDP1 confere o fenótipo anucleado ou multinucleados as células de leveduras (Foreman \& Davis, 1996). O isolamento e caracterização da mutação do gene 
bncA é de extrema importância para o entendimento e conexão entre o ciclo celular e a morfogênese em fungos filamentosos.

\section{c Mutantes que afetam a distribuição nuclear nas hifas e conidióforos}

A migração nuclear é necessária para o crescimento e desenvolvimento dos fungos filamentosos, Morris (1976) iníciou seus estudos em mutantes de $A$. nidulans, para a migração nuclear, sendo identificado um mutante denominado de nud ("uclear distribution") que afeta a distribuição nuclear.

A análise microscópica dos mutantes nud, realizada por Morris (1976), demonstrou que os núcleos não migravam, sendo incapazes de se distribuir normalmente ao longo do tubo germinativo, contudo estas mutações não afetam a mitose.

O gene nudA foi isolado e caracterizado por Xiang et al. (1994), a mutação deste gene é responsável pelo bloqueio na distribuição dos núcleos ao logo do tubo germinativo, sendo que os mesmos ficam acumulados nos conídios, eventualmente o núcleo quebra o bloqueio e migra, possibilitando o crescimento da hifa, mas este é muito lento. A determinação da seqüência de aminoácidos demonstrou que a proteína NUD possui quatro sítios de ligação ao ATP, sendo uma característica de proteínas da cadeia pesada da dineína citoplasmática, a qual é uma proteína motora encontrada em todos os organismos, desde as leveduras até os mamíferos. O complexo formado por diversas cadeias da dineína tem função no transporte de organelas membranosas (Hirokawa, 1998). A descoberta deste gene em A. nidulans caracterizou a dineína como o principal motor celular encarregado da distribuição nuclear na hifa vegetativa (Fischer, 1999).

Goldman \& Morris (1995) isolaram supressores extra gênicos de nudA, a seleção foi feita para os mutantes que contribuíssem para a melhora da distribuição nuclear na hifa vegetativa e esta estratégia teve o objetivo de descobrir genes que interagem com a cadeia pesada da dineína. A análise mutacional identificou cinco genes que são capazes de restaurar o crescimento vegetativo na ausência de nudA.

O gene nudC3, apresenta incapacidade de distribuir seus núcleos, sendo que ocorrem três divisões nucleares normais, porém os oitos núcleos nunca chegam a 
serem distribuídos ao longo da hifa vegetativa (Morris, 1976). A clonagem e o mapeamento físico deste gene não veio a esclarecer qual seria o mecanismo pelo qual nudC age, uma vez que a seqüência de aminoácidos possui homologia com proteínas que não tem função conhecida. Porém, a proteína é bastante conservada, tendo homólogos em Drosophyla melanogaster, Caenorhabditis elegans e Homo sapiens (Osmani et al., 1990).

O mutante nudF foi identificado por Morris (1976), posteriormente, durante a tentativa de clonar o gene $n u d \mathrm{C}$, nudF, sendo identificado como um supressor multicópia de nudC. A relação entre nudC e nudF foram estabelecidas quando se detectou que a ausência de nudC que regula nudF. Este resultado demonstrou que nudF se encontra sob controle do promotor da álcool desidrogenase (alcAp) em condições de indução. Estes dados sugerem que nudC regula nudF de forma pós-transcricional, elevando os níveis desta proteína. É possível que estas duas proteínas façam parte de um complexo sendo que, NUDC não está presente e NUDF está sujeita a degradação (Xiang et al., 1995a).

Morris et al. (1997) iniciaram uma estratégia para identificar genes responsáveis pela indução, por prolactina, em culturas de células T de rato. Neste estudo, os autores identificaram um clone, o c15, sendo que seu sequenciamento demonstrou homologia de $68 \%$ com o gene nudC. Neste trabalho foi possível provar que existe homologia funcional entre o clone c15 e nudC, sendo que c15 é capaz de complementar a mutação nudC3, e também de restaurar os níveis de $n u d \mathrm{~F}$.

Xiang et al. (1995b), realizando estudos com nudF, demonstraram que seu transcrito é constituído por 444 aminoácidos, além de apresentar $41 \%$ de homologia com a proteína LIS1. O mutações no gene lis1 causam deficiências durante o desenvolvimento cerebral por falhas na migração dos neurônios, originando a síndrome de "Miller-Dieker" (Reiner et al., 1993; Nigro et al., 1997).

O gene lis1 ("lissencephaly") está localizado no cromossomo 17p13.3 (Leventer et al., 2000; Ledbetter, 1992; Reiner, 1993) e codifica a proteína LIS1 (a qual é composta por duas subunidades PAFAH1B1 que pode atuar como uma proteína associada aos microtúbulos e PAFAH), que é altamente conservada entre ratos e 
humanos. Estudos realizados demonstraram que a subunidade PAFAH1B1 possui $42 \%$ homologia com nudF (Leventer et al., 2000). Matsumoto \& Ledbetter (1999) realizaram estudos de hibridização "in situ" entre lis1 e nudC isolados de humanos, demonstrando que ambos são co-expressados e pertencentes as proteínas MAPs ("Microtubule Associated Proteins"). Um dos últimos mutantes nuds descrito, foi o gene nudG, que codifica a cadeia leve de dineína (Beckwith et al., 1995), este gene esta restritamente relacionado com o gene nudA, onde ambos codificam subunidades da proteína motora dineína (Xiang et al., 1994). As proteínas NUDG e NUDA provavelmente estão diretamente envolvidas na translocação nuclear (Holzbaur \& Vallee, 1994).

Clutterbuck (1994) isolou dois novos mutantes para o desenvolvimento asp A e $a s p \mathrm{~B}$, estes mutantes bloqueiam o desenvolvimento assexual na fase de métula, o bloqueio está associado à falha na migração nuclear da vesícula para a métula do conidióforo. Por causa da característica de métula anucleada este mutante foi denominado de aps ("ạnucleate primary șterigmata"), além disto à hifa vegetativa deste mutante apresenta uma distribuição anormal dos núcleos (Clutterbuck, 1994; Fischer \& Timberlake, 1995). Suelmann et al. (1997) demonstraram que a distribuição anormal na hifa vegetativa não era permanente, sendo que ocorre a reorganização nuclear após algum tempo. A provável causa para o agrupamento dos núcleos durante o desenvolvimento da hifa vegetativa é que os núcleos iniciam seu movimento para uma região específica, movimento direcionado, e após um determinado período esta direção é mudada para um outro local diferente. Para tentar compreender como corre a interação entre desenvolvimento anormal do conidióforo com a distribuição anormal de núcleo nas métulas, Fischer (1999) propôs duas hipóteses: a primeira consiste, que o núcleo não migra para a métula; e a segunda sugere que os núcleos migram para as métulas, como ocorre nas linhagens selvagens, mas devido ao aumento da motilidade dos núcleos, eles deixam a célula antes que o septo esteja formado.

Um mutante supressor foi isolado por Krüger \& Fischer (1996), este mutante recuperou o fenótipo asp dos conidióforos. Aparentemente os mutantes asp não apresentam anormalidades na migração nuclear, mas ocorre uma alteração no posicionamento do núcleo no interior da hifa e conidióforos, sugerindo que o gene asp 
possui função relacionada com a regulação do posicionamento do núcleo. Suelmann et al. (1997) sugeriram que o nível do regulamento na posição do núcleo pode ocorrer durante a migração do núcleo pela hifa vegetativa e que este núcleo ao chegar em um determinado local poderia ocorrer dois eventos, primeiramente a desconexão da força motriz e mais a fixação do núcleo. Embora estes eventos não estejam completamente compreendidos a proteína do gene asp pode estar envolvida na regulação da fixação do núcleo.

O gene asp foi clonado e seqüenciado, apresentando uma proteína de 183 $\mathrm{kDa}$, que possui um alta probabilidade para a formação de uma estrutura em espiral (“coiled-coil”) (Fischer \& Timberlake, 1995). A função da proteína não é clara, mas devido a presença de um domínio $\mathrm{PH}$ encontrado na cadeia C-terminal, ela pode ser descrita como um proteína transcricional (Gibson et al., 1994; Lemmon et al., 1996; Musacchio, 1993).

O domínio PH é responsável pelo direcionamento da proteína APSA para membrana plasmática (Suelmann et al., 1997). Trabalhos realizados com imuno localização demonstraram que esta proteína está presente junto ao córtex da hifa, e a remoção deste domínio resultou na agregação citoplasmática do polipeptídeo (Salim et al., 1996). A proteína APSA apresenta homologia com a proteína NUM1p ("nuclear migration") de leveduras. A mutagênese realizada em num1 resultou em uma alta freqüência de células binucleadas (Kormanec et al., 1991). Recentemente, um gene homólogo a aps foi clonado em Podospora anserina, os mutantes para este gene produzem microconídios anucleados (Fischer, 1999).

Um segundo gene envolvido no posicionamento nuclear, o aps $\mathrm{B}$ foi clonado em A. nidulans (Suelmann et. al., 1998), este codifica uma proteína de $121 \mathrm{kDa}$ com alta probabilidade para formação de uma estrutura em espiral (“coiled-coil"), isto é, possui domínios espiralizados. A identificação de componentes interagindo com as proteínas APSA e APSB são necessárias para melhor compreensão da função destas proteínas.

Queiroz \& Azevedo (1998) descreveram um novo mutante para a distribuição nuclear em hifas durante a conidiogênese, este gene se encontra no 
cromossomo VII, sendo denominado de anuA ("anucleate - Multinucleate conidia and hypha compartments").

\subsubsection{Aquisição da Competência}

Uma vez estabelecido o crescimento polarizado da hifa e suas ramificações, tem início a colonização do substrato para a formação do tecido vegetativo, o micélio.

O fungo $A$. nidulans pode manter-se indefinidamente no estágio vegetativo do seu ciclo de vida, sendo que a conidiogênese normalmente ocorre após este período (Kronstad \& Staben, 1997; Morris, 1976). A esporulação assexual e sexual ocorrem unicamente na exposição de superfícies aeradas e aproveitando-se desta condição, é possível sincronizar e induzir o desenvolvimento da conidiogênese (Axelrod, 1972; Law \& Timberlake, 1980).

O estabelecimento da competência é dependente de condições particulares empregadas para cada meio de cultura, mas geralmente a competência é adquirida após 20 horas de crescimento a $37^{\circ} \mathrm{C}$, antes deste período, as colônias são incapazes de entrar na conidiogênese mesmo que ocorra a indução por aeração. Axelrod et al. (1973) e Miller (1990) observaram que antes de 20 horas de crescimento, as células não respondem à indução, e após este período a resposta leva horas para se realizar, as células capazes de responder imediatamente à indução são consideradas como competentes. O processo de controle para aquisição da competência obedece a um controle endógeno, isto porque fatores como densidade de células e fornecimento contínuo de meio de cultura não surtem efeito sobre o início da conidiogênese (Pastushok \& Axelrod, 1976).

O início da conidiogênese é dependente de aeração, mas os mecanismos que controlam este evento não são compreendidos, o provável sinal para o início da conidiação possivelmente não está associado com mudanças nos níveis de $\mathrm{O}_{2}$ e $\mathrm{CO}_{2}$ nas superfícies aerada e líquida (Sánchez-Garcia \& Rabbitts, 1994), mas que sejam induzidos por sinais genéticos. A conidiação também é dependente de luz. Em linhagens selvagens de $A$. nidulans a conidiação ocorre devido a presença do alelo do gene velvet (ve $\left.{ }^{+}\right)$, que é 
dependente de luz vermelha. As linhagens que apresentam a mutação veA1 são capazes de promover a conidiação na ausência de luz (Vierula \& Mais, 1997).

Butnick et al. (1984a, b) isolaram diversos mutantes termossensíveis (temperatura de $28^{\circ} \mathrm{C}$ ), três mutantes apresentaram bloqueios específicos de fase de précompetência. As análises de alternância de temperatura mostraram que os produtos destes genes são necessários durante o mecanismo de crescimento submerso, sendo que todos os três mutantes foram incapazes de desempenharem o ciclo assexual e sexual corretamente (Yager et al., 1982).

Os mecanismos genéticos que coordenam a aquisição da competência são pouco conhecidos, mas apresentam enorme relevância, uma vez que todas as células que se diferenciam dependem de tal mecanismo para adaptação e sobrevivência do organismo.

\subsubsection{Ciclo Assexual}

\subsubsection{Formação do Conidióforo}

A germinação do esporo leva a formação de hifas tubulares que crescem de forma polar por extensão apical e ramificam-se formando redes interconectadas de células denominadas de micélio. Após 16 horas, aproximadamente, da germinação do esporo, ocorre a primeira evidência fenotípica de especialização da hifa a qual é observada dentro da colônia (Lee \& Adams, 1994a, b). A hifa aérea ramificada diferencia-se em um conidióforo, estrutura reprodutora do ciclo assexual de A. nidulans (Adams et al., 1998). O

processo de desenvolvimento e de diferenciação do conidióforo, até a formação dos conídios, constitui a Conidiogênese.

A ultraestrutura do desenvolvimento e diferenciação do conidióforo de $A$. nidulans, analisada por Mims et al. (1988) e revisada por Timberlake \& Clutterbuck (1994), pode ser dividida em cinco estágios de desenvolvimento:

1. o primeiro estágio do desenvolvimento do conidióforo envolve a transformação de uma célula de hifa em uma célula pé (Figura 1), estrutura que sustenta $\mathrm{e}$ desenvolve o conidióforo. A célula pé pode ser distinguida das outras células por possuir duas camadas de parede celular. A camada exterior ou parede primária é constituída pela 
parede da própria hifa basal e a camada mais interna ou parede secundária limita o início e o final da célula pé (Oliver, 1972). Em relação ao núcleo, a célula pé pode ser uninucleada, ou ocorrer mais de um núcleo, como foi demonstrado em heterocários (Clutterbuck \& Spathas, 1984; Pizzirani-Kleiner \& Azevedo, 1986a, b). A partir da célula pé, há o desenvolvimento da haste do conidióforo, que é multinucleada e asseptada. A região apical da haste é rica em vesículas que possuem substâncias precursoras e polimerizadoras da parede celular. As vesículas fundem-se à membrana plasmática promovendo o alongamento da haste (Gooday, 1983);

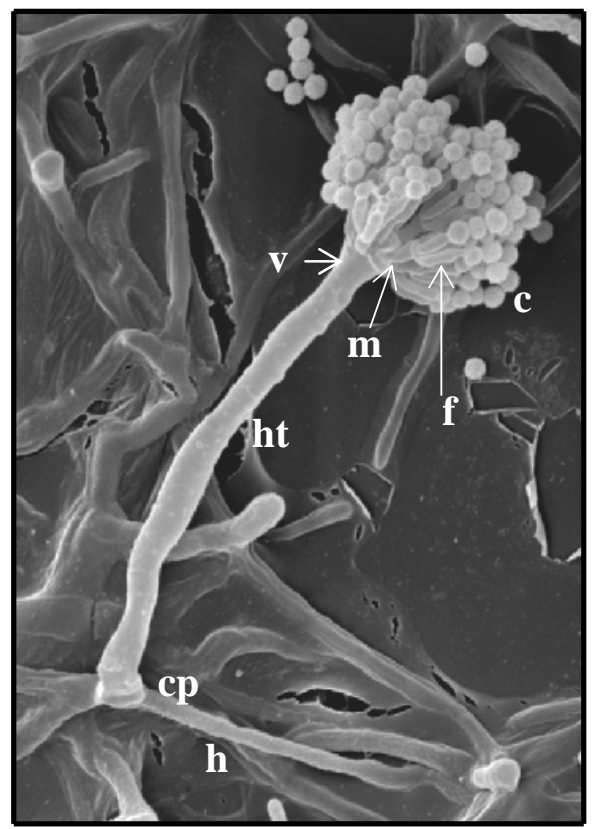

Figura 1 - Conidióforo de Aspergillus nidulans. (h) hifa, (cp) célula pé, (ht) haste do conidióforo, (v) vesícula do conidióforo, (m) métula ou esterígma primário, (f) fiálide ou esterígma secundário, (c) conídios. Foto de microscopia eletrônica de varredura, aumento 1500 x (Giancoli, 2000)

2. a partir da célula pé forma-se a haste do conidióforo, que sofre alargamento gradual do seu ápice formando uma vesícula, que também possui dupla camada de parede celular. Durante a formação da vesícula do conidióforo, ocorre acúmulo de vesículas intracelulares, que possuem em seu interior substâncias precursoras e polimerizadoras da parede celular no ápice da vesícula (Oliver, 1972). A vesícula do conidióforo possui vários núcleos que sofrem divisão mitótica; 
3. com a vesícula formada, tem início o desenvolvimento das métulas, as quais surgem como protuberâncias na superfície interna da parede da vesícula, isto provavelmente pela dissolução da parede secundária. Durante o desenvolvimento das métulas, são observados agregados nas protuberâncias das vesículas, de onde emergem as métulas. As vesículas citoplasmáticas persistem no ápice das métulas até seu completo desenvolvimento, a sua função, provavelmente, está relacionada com a formação da parede celular do fungo. Oliver (1972) também observou um grande número de vesículas citoplasmáticas, que estão aderidas na parede celular das métulas, provavelmente responsáveis pela síntese de novas paredes celulares. Em relação ao núcleo, ocorre a migração nuclear da região apical da vesícula para a métula, tornando-a uninucleada, e posteriormente sofre divisão mitótica. A delimitação entre vesícula e métula ocorre pela deposição de um septo descontínuo, com poro central que permite a comunicação citoplasmática entre os dois compartimentos;

4. no ápice das métulas ocorre o brotamento das fiálides. O núcleo presente na métula sofre divisão mitótica, originando um núcleo filho, que migra para a fiálide, sendo que outro núcleo permanece na métula. A comunicação citoplasmática entre a métula e fiálide ocorre pela formação de septos descontínuos com poro central;

5. ao completar o desenvolvimento das fiálides tem início a formação dos conídios primários, os quais são originários do ápice das fiálides, durante este processo ocorre uma divisão mitótica do núcleo presente na fiálide, o núcleo filho migra para o conídio em formação (Bergen \& Morris, 1983; Pascon, 1994). A formação da parede celular dos conídios tem início com o prolongamento das paredes primárias e secundárias das fiálides e no decorrer da maturação dos conídios ocorre deposição de novas membranas, tornando-os impermeáveis e garantindo a sua dormência.

\subsubsection{Principais Mutantes para a Conidiogênese}

Clutterbuck (1969) e Martinelli \& Clutterbuck (1971) foram os primeiros a estudarem e descreverem mutantes para o desenvolvimento em A. nidulans. A análise de mutantes para os diferentes passos da conidiogênese tem permitido esclarecer o 
desenvolvimento e diferenciação em A. nidulans. Esses mutantes se enquadram em duas classes de acordo com Timberlake (1990):

a - Classe I, mutantes relacionados com a aquisição de competência, isto é, genes que controlam a transição do crescimento indiferenciado da hifas para a diferenciação do conidióforo.

B - Classe II, mutantes que afetam a formação do conidióforo e conídio.

Essa última classe é subdividida em quatro grupos conforme, Clutterbuck (1969):

b1 - mutantes para alterações conidiais yA ("yellow conidia, laccase I"); wA ("white conidia, polyketide synthase"); fwA ("fawn conidia"); wetA ("wet-white conidia");

b2 - mutantes com alteração no conidióforo, mas que não afetam a formação dos conídios stuA ("stunted"); medA ("medusa");

b3 - mutantes que bloqueiam a formação dos conídios brlA ("bristle") abaA ("abacus");

b4 - mutantes que afetam a pigmentação dos conídios ivoA ("ivory"); ivoB.

Em outra classificação, Miller et al. (1991 e 1992) e Miller (1993) dividem os mutantes em dois grupos: "bristle" e "stunted", sendo que no primeiro estão incluídos três genes (brlA-bristle $\rightarrow$ abaA-abacus $\rightarrow$ wetA-wet-white) que atuam em cadeia epistática e sem os quais não há formação do conidióforo e dos conídios e no segundo grupo, dois genes estão envolvidos stuA $\rightarrow$ medA.

\section{a Mutantes de Classe I}

Os genes pertencentes à classe $\mathrm{I}$, isto é, mutantes relacionados com a aquisição da competência, são inúmeros. O gene velvet (veA) merece destaque, pois em linhagens selvagens são responsáveis pela dependência da luz como estímulo inicial para a conidiogênese (Mooney \& Yager, 1990). Esse gene é pleiotrópico, sendo que o mutante veA1 não produz hifas aéreas típicas, como da linhagem selvagem (Kafer, 1960; 1961), além de ser incapaz de produzir cleistotécios a $42^{\circ} \mathrm{C}$ (Champe et al., 1981). 
Outro mutante de interesse é o flu ("fluffy"), que apresenta micélio aéreo indiferenciado e invasivo, perdendo a inibição por contato e crescendo sobre outras colônias (Ball \& Azevedo, 1964; Tamame, et al., 1983). Estes mutantes se caracterizam pela formação de grandes quantidades de hifas aéreas que nunca chegam a diferenciar conidióforos e são incapazes de respeitar os limites de crescimento de uma colônia vizinha que apresenta desenvolvimento normal.

O tratamento das hifas com 5-azacitidina interfere na expressão do fenótipo flu, este agente mutagênico é incorporado no lugar da citosina e inibe a ação da enzima metiltrasferase, causando hipo-metilação e a ativação imprecisa de genes silenciados por meio da metilação de bases. Vários mutantes flu foram isolados por esta metodologia e a realização do mapeamento genético demonstrou que todos os mutantes são alelos de um mesmo gene que foi mapeado no cromossomo VIII, tendo estreita ligação com o centrômero (Tamame \& Santos, 1988).

Diversos mutantes flu, como acoD684 ("aconidial") foram descritos e estudados por genética clássica e molecular (Yager et al., 1992; Wieser et al., 1994; De Vries et al., 1995; Yu et al., 1996; Marhoul \& Adams, 1996; Adams et al., 1998; Pascon, 1998).

\section{b Mutantes da Classe II}

Por meio de estudos moleculares, foi possível demonstrar que a conidiogênese possui dois genes principais descritos e identificados o brlA e abaA, os quais são requeridos especificamente para o desenvolvimento normal dos conídios, não afetando o início do desenvolvimento do ciclo assexual (Clutterbuck, 1969). Juntamente com um terceiro gene o wetA, brlA e abaA, podem ser considerados como os genes principais, que atuam no caminho central da regulação do desenvolvimento da conidiogênese Estes três genes, juntamente com outros genes, são responsáveis pelo controle da expressão gênica da conidiação, determinando a ordem da ativação durante o desenvolvimento e maturação do esporo (Boylan et al., 1987).

Os mutantes "bristle" (brl) e "abacus" (aba) são classificados como mutantes aconidiais. Os mutantes brl foram incluídos neste grupo devido a algumas 
linhagens desenvolverem apenas a haste do conidióforo, que se alongam até 2 - $3 \mathrm{~mm}$ e não desenvolvem vesículas nem qualquer outra estrutura subseqüente na diferenciação do conidióforo. Entretanto, muitos outros mutantes brandos para o gene brl desenvolvem conidióforos aberrantes, com cadeias de métulas que se diferenciam e originam novos conidióforos. Os conídios podem ser formados em maior ou menor quantidade, de acordo com o nível de comprometimento dos conidióforos (Rocha, 1997; Castro-Prado \& Rocha, 1998). Clutterbuck (1969) observou que entre 36 mutantes brl, muitos apresentavam fenótipos intermediários entre "bristle" grave, onde ocorre apenas a formação da haste do conidióforo ao fenótipo normal sugerindo a formação de um gradiente de fenótipos "bristle" grave ao fenótipo normal. Este gradiente entre fenótipos foi comprovado por estudos de mutantes "bristle" sensíveis à temperatura e osmolaridade (Clutterbuck, 1970a, b).

O gene "bristle" de linhagens selvagens de A. nidulans foram isolados por complementação de mutantes (Boylan et al., 1987; Johnstone et al., 1985), demonstrando que o mesmo codifica um fator de transcrição do tipo "zinc-finger" (Evans \& Hollenberg, 1988). Os resultados obtidos mostram duas unidades de transcrição denominadas de brlA $\alpha$ e $\operatorname{brlA} \beta$. A unidade $b r l A \alpha$ possui $2,1 \mathrm{~kb}$ e a unidade $b r l \mathrm{~A} \beta$ apresenta 2,5 kb. Estas unidades ao serem transcritas em polipeptídio apresentam uma diferença de 23 aminoácidos a mais para a unidade $b r l A \beta$. Durante o início da transcrição, ocorre sobreposição na região estrutural, isto é, as duas subunidades estariam sobrepostas, sendo que o transcrito brlA $\beta$ inicia a transcrição a quase $1 \mathrm{~kb}$ à frente do transcrito brlA $\alpha$. Mutações expressando cada um dos transcritos sozinhos levam a um desenvolvimento anormal do conidióforo (Prade \& Timberlake, 1993). De qualquer modo, múltiplas cópias de qualquer $b r l A \alpha$ ou $b r l A \beta$ podem compensar a falta do outro. Estes resultados são consistentes com a hipótese de que a transcrição das unidades brlA $\alpha$ e $b r l A \beta$, são individualmente essenciais para o desenvolvimento normal do conidióforo, mas cada produto das unidades possui funções redundantes. Han et al., (1993) demonstraram que brlA $\alpha$ e $b r l A \beta$ são controlados por diferentes mecanismos moleculares, sugerindo que a unidade de transcrição do loco brlA $\alpha$ é expressa durante todo o desenvolvimento. 
O gene brlA, codifica a proteína BRL, que possui 432 aminoácidos, sendo rica em prolina (10\%), além de possuir duas regiões apresentando a conformação denominada de "zinc-finger", que consistem em estruturas protéicas características de ligação ao DNA (Johnston et al., 1985; Adams et al., 1998). Supõe-se que esta proteína tenha uma função de regulação, uma vez que se liga ao DNA, sendo sua presença necessária para desencadear o desenvolvimento do conidióforo (Adams et al., 1998).

O mutante para o gene "abacus" (aba) apresenta conidióforos com estruturas que lembram um ábaco, em lugar de fiálides e conídios. A análise ultraestrutural destes mutantes indica que estas estruturas são intermediárias entre métulas e fiálides (Sewall et al., 1990; Rocha, 1997).

A clonagem e o mapeamento físico do gene abaA demonstraram que este codifica um fator de transcrição. ABAA é uma proteína de ligação ao DNA que reconhece a seqüência "CATTCY". Além de possuir uma região estrutural semelhante a uma "leucina zipper", indicando um domínio de dimerização nesta região, processo que freqüentemente requerido nos fatores de transcrição (Boylan et al., 1987).

A ativação de $a b a \mathrm{~A}$ com um promotor forte, $a c_{(\mathrm{p})}(a l c \mathrm{Ap}:: a b a \mathrm{~A})$, em hifas vegetativas, resulta na interrupção do crescimento acentuado da vacuolização celular, mas não na diferenciação dos conídios (Adams et al., 1990; Mirabito et al., 1989). A indução do gene abaA também leva à ativação de alguns genes específicos para o desenvolvimento, sendo alguns conhecidos como wetA e brlA e outros ainda desconhecidos. Os genes wetA e brlA são induzidos reciprocamente, mas a expressão de brlA deve ocorrer antes da expressão de abaA para o desenvolvimento reprodutivo do conidióforo. Para a formação das fiálides apenas a expressão de brlA é necessária, mas para as fiálides tornarem-se funcionais e produzirem conídios, é necessária a expressão do gene abaA (Adams et al., 1998). A expressão induzida de brlA, nas hifas indiferenciadas, ativa a transcrição de $a b a \mathrm{~A}$ com o desenvolvimento de fiálides funcionais. A ativação induzida de gene abaA não leva à formação imediata de fiálides e conídios, mas ativa a transcrição do gene brlA, causando alterações morfológicas no conidióforo. Devido a esse comportamento, a ativação do gene $a b a$ deve ocorrer ordenadamente, para que a diferenciação de fiálides funcionais ocorra normalmente. Desse modo, as mutações brlA 
são epistáticas para as mutações $a b a \mathrm{~A}$ e wetA, e a mutação $a b a \mathrm{~A}$ é epistática para a mutação wetA, em ambos níveis moleculares e morfológicos (Sewall et al., 1990). Todos os dados reunidos sobre o desenvolvimento dos conidióforos sugerem que os três genes wetA, brlA e abaA que controlam a diferenciação temporal e espacial do conidióforos em A. nidulans (Mirabito et al., 1989).

Os genes "stunted" (stu) e "medusa" (med) são considerados como modificadores do conidióforo. Esses genes são requeridos para uma série de divisões celulares que estabelecem a organização espacial e temporal do conidióforo. Mutações em qualquer um destes dois genes proporcionam o desarranjo da organização espacial e temporal do conidióforo, mas ambos genes produzem conídios viáveis (Clutterbuck, 1969).

Mutações no gene stuA resultam na produção de conidióforos curtos com a falta de métulas e fiálides, e a produção de conídios ocorre diretamente da vesícula do conidióforo (Rocha, 1997). O gene stuA é um codificador de um fator de transcrição bHLH ("basic-helix-loop-helix") que possui similaridade com fatores de transcrição de outros eucariotos (Gimeno et al., 1992; Gimeno \& Fink, 1994), esta proteína possui um domínio de ligação ao DNA do tipo "APSES”, os quais regulam importantes processos biológicos, sendo incluídas SWI4, MPB1 e PHD1 de S. cerevisiae e RAS1 e CDC10 para S. pombe.

O gene stuA possui maior similaridade com o gene phd1 S. cerevisiae, onde sua expressão leva à indução de pseudo-hifas, que podem ser completas morfologicamente e talvez funcionalmente análogas aos conidióforos (Gimeno et al., 1992 e 1994). Durante o desenvolvimento da pseudo-hifa nos mutantes para o gene phd1, ocorre elongação polar de células mãe, originando células filhas que irão produzir os filamentos. Este caminho do desenvolvimento de pseudo-hifas é semelhante à morfogênese do conidióforo, onde a elongação de métulas e fiálides consiste do resultado da germinação polar das vesículas. Estas divisões polares são necessárias para mutantes stuA. Entretanto, a expressão do gene stuA permite o gene brlA orientar a diferenciação terminal e promover o crescimento das pseudo-hifas (Busby et al., 1996). Portanto, além da homologia de seqüências existente entre as proteínas, é possível traçar uma homologia funcional, onde stuA é indispensável para a diferenciação das métulas e fiálides, as quais são estruturas consideradas morfologicamente análogas à pseudo-hifas (Miller et al., 1991 e 1992). 
Dutton et al. (1997) caracterizaram stuAp como um repressor da transcrição, os autores observaram que os transcritos brlA e abaA tornam-se temporal e espacialmente desregulado na ausência de stuA. Foi proposto um modelo de regulação gênica do desenvolvimento assexual, em que o modificador da complexidade do conidióforo, stuA, atua por meio da modulação da transcrição de genes que dirigem a diferenciação terminal do conidióforo, como brlA e abaA. stuA provavelmente é responsável pela fina sintonia da expressão dos genes responsáveis pela diferenciação terminal. Isto explica por que a indução de $b r l A$ em altos níveis na hifa vegetativa, causa a formação de conidióforos rudimentares com baixo nível de complexidade, exatamente como aqueles formados pelas linhagens que possuem o gene stuA deletado. Isto reafirma a hipótese que stuA e brlA precisam ser paralelamente expressos para que o conidióforo possa adquirir a complexidade e a funcionalidade necessária para a produção de conídios.

O gene "medusa" (medA) leva à formação de conidióforos de tamanhos normais, mas as métulas não sofrem diferenciação, originando novos conidióforos completos (Rocha, 1997). Semelhante aos genes stuA e brlA, o gene medA também possui dois transcritos (Adams et al., 1998). Enquanto stuA é importante para a distribuição espacial do transcrito do gene $b r l A$, o gene medA aparentemente é requerido para a correta expressão temporal do mesmo (Busby et al., 1996). Ambos transcritos brlA $\alpha$ e brlA $\beta$ são detectados mais cedo em mutantes stuA do que em linhagens selvagens, além disso o transcrito $b r l A \alpha$ continua a ser produzido, mesmo com o desenvolvimento completo do conidióforo, o que não ocorre com linhagens selvagens (Adams et al., 1998).

O gene "abacus" (abaA) é essencial para o desenvolvimento das fiálides. Linhagens que apresentam a mutação medA possuem a expressão anormal do gene abaA, sendo esta reduzida ou ausente (Busby et al., 1996). O fenótipo mutante de medA é supresso por uma cópia extra do gene brlA, mas esta supressão é sensível à variação da temperatura (Busby et al., 1996). Esses resultados indicam uma interação física entre medA e blrA, demonstrando que isso ocorre através de medA que atua como estabilizador do complexo transcricional, que está presente o gene "bristle". 
Os genes wetA, $y \mathrm{~A}$, wA e drk ("dark conidial colour") são caracterizados como modificadores do conidióforo, estando também relacionados com a pigmentação dos conídios.

Os mutantes "dark" (drk) possuem a coloração mais escura que a linhagem padrão de $A$. nidulans, além de possuírem uma camada mais externa da parede celular que envolve não apenas os conídios, mas forma um saco que engloba toda a cadeia de conídios (Oliver, 1972).

O loco wA pode ser considerado o primeiro de uma cadeia epistática, responsável pela coloração dos conídios. O loco wA codifica uma enzima que converte um precursor em um produto secundário, que servirá de substrato para a enzima $\rho$ - difeno oxidase (lacase) que é codificada pelo loco $y \mathrm{~A}$

O loco yA foi identificado por Pontecorvo et al. (1953) por meio de mutações. Este gene confere a característica de conídios amarelos ao invés de conídios verdes. $\mathrm{O}$ gene $y$ A codifica a enzima $\rho$ - difeno oxidase (lacase), rica em cobre, que possui a função de converter o pigmento amarelo intermediário em pigmento verde, cuja função é proteger o conídio da radiação ultravioleta. Mutantes $w \mathrm{~A}^{-}$possuem conídios brancos. $\mathrm{O}$ loco $w \mathrm{~A}$ é epistático para $y \mathrm{~A}$, indicando que os genes $w \mathrm{~A}$ e $y \mathrm{~A}$ codificam enzimas envolvidas na síntese do mesmo pigmento, responsável pela coloração do conídio (Clutterbuck, 1972). O gene yA foi isolado e clonado por O' Hara \& Timberlake (1989), apresentando um fragmento de 2,2 kb, que complementa a mutação $y \mathrm{~A}_{1}$. Este gene está localizado no grupo de ligação I entre os marcadores auxotróficos paba $\mathrm{A}_{1}$ e bi $\mathrm{A}_{1}$.

O gene "wet - white" (wet) apresenta conídios brancos, aparentemente normais, mas que apresentam autólise poucos dias depois de maduros (Rocha, 1997). O gene wetA codifica um polipeptídio rico em serina (14\%), treonina (17\%) e prolina $(10 \%)$ (Marshall et al., 1991). Este polipeptídio não se encontra presente em células indiferenciadas do micélio, mas aparece acumulado durante a maturação dos conídios. A análise da seqüência do gene wetA não fornece uma clara indicação da função deste, mas especula-se que este gene é um controlador da expressão de gene esporo - específico (Marshall et al., 1991). Esta hipótese baseia-se em estudos de diversos mutantes wetA, os 
quais acumulam uma grande quantidade de mRNA específico durante a conidiação (Boylan et al., 1987).

Entre os mutantes para pigmentação do conidióforo, destacamos o mutante "ivory" (ivoA), que possui independência da coloração dos conídios, apresentando conidióforos sem pigmentação marrom característica. Este gene demonstrou interessante relação com o gene brlA, uma vez que mutantes severos para brlA também eram mutantes ivoA, embora esses dois genes não fossem ligados (Clutterbuck, 1969; 1990; Rocha, 1997). O gene ivoA foi mapeado no cromossomo III e o gene ivoB está presente no cromossomo VIII (Clutterbuck, 1969; 1997).

Estudos realizados por Karos \& Fischer (1996), em mutantes para o desenvolvimento de A. nidulans, foi identificado um novo mutante, o hym ("hypha-like metulae"), que apresenta crescimento irregular e reduzido das hifas e o desenvolvimento do conidióforo é bloqueado no estágio de métula.

Melin et al. (2003) identificaram um gene, phiA, responsável pelo desenvolvimento das fiálides, esta mutações causa redução no crescimento das fiálides e uma severa redução da esporulação.

\subsubsection{Interação entre Ciclo Celular, Migração Nuclear e Conidiogênese}

As análises moleculares do desenvolvimento assexual de A. nidulans promovem a identificação de um complexo sistema caracterizado por mecanismos de controle transcricional que levam a expressão diferencial nos genes requeridos para a formação dos conidióforos. O modelo conhecido de crescimento celular, divisão nuclear e citoquinese, sofrem alterações durante a formação das diferentes células que compõe o conidióforo (Mirabito \& Osmani, 1994). Isto pode ser observado após o período de crescimento vegetativo as hifas, onde uma célula se diferenciar em célula pé, acarretando todo o processo de transformação celular, finalizando com a formação completa do conidióforo (Mims et al., 1988). As mudanças morfológicas para o desenvolvimento do conidióforo ocorrem em função de genes regulatórios que codificam ativadores ou repressores transcricionais e genes funcionais que codificam, 
por exemplo, enzimas envolvidas na síntese do pigmento verde para o esporo (Prade \& Timberlake, 1993; Miller et al., 1991). Além desses genes específicos para o desenvolvimento, ocorre a ativação combinada de diversos outros genes (Morris et al., 1995; Navarro et al., 1996; Karos \& Fischer, 1999).

Durante o desenvolvimento do conidióforo, a hifa vegetativa multinucleada sofre alteração nas quais formam células específicas (métulas e fiálides) que são uninucleadas (Ye et al., 1995; Fischer \& Timberlake, 1995), sugerindo que a migração nuclear exerce função primordial no desenvolvimento. Isto pode ser observado em mutantes aps A e apsB, onde as métulas não recebem o núcleo provindo da vesícula e portanto ocorre bloqueio no desenvolvimento do conidióforo (Clutterbuck, 1994).

Ye et al. (1999), estudando mutações brlA de A. nidulans, a qual leva a anormalidades morfológicas dos conidióforos, demonstraram que durante o seu desenvolvimento ocorre o aumento da atividade quinase de NIMX ${ }^{\text {cdc2 }}$ e NIMA. Este estudo demonstrou que nim $\mathrm{X}^{\text {cdc2 }}$ é regulado pelo gene de desenvolvimento brlA, apresentando função na regulação dos genes para o ciclo celular. Evidentemente a interação entre os genes reguladores do desenvolvimento morfogenético e os genes reguladores do ciclo celular são essenciais para a morfogênese correta em A. nidulans.

Outro exemplo interessante da interação entre o ciclo celular e a morfogênese em diferentes tipos celulares é o mutante bncA1. O mesmo foi inicialmente isolado como um mutante produtor de conídios binucleados e trinucleados (PizziraniKleiner \& Azevedo, 1986a, b). A análise da morfologia do conidióforo demonstrou que a mutação não afeta apenas o número de núcleos, como também a morfogênese da métulas e fiálides (Pascon, 1994; Pascon, 1998; Giancoli, 2000; Pascon et al., 2001), estas são freqüentemente multinucleadas e assumem uma morfologia tubular que lembra mais um fragmento de hifa, possuindo septos que dividem a fiálide em compartimentos, lembrando uma pseudo-hifa (Pascon et al., 2001).

Schier et al. (2001), isolaram um novo mutante para o desenvolvimento, pclA ("cyclin, aconidial"), que altera a morfologia dos conidióforos e diminuí a esporulação, a proteína PCLA é uma "cyclin-dependent kinase" homóloga de leveduras, e estudos realizados demonstraram que esta proteína também é responsável pelos altos 
níveis transcricionais durante a fase $\mathrm{S}$ da mitose, os dados obtidos sugerem que o papel de PCLA conjuntamente com NIME é mediar eventos do ciclo celular com estágios tardios da esporulação.

\subsection{Elementos de Transposição (TEs)}

Durante a década de 1950, Bárbara McClintock, pesquisadora do "Carnegie Dept. of Genetics, Cold Spring Harbor" investigava variedades de milho (Zea mays), em uma destas variedades foi encontrado um par de locos gênicos que apresentavam mutação espontânea e reversível. O fenótipo característico desta mutação constituía-se de grãos variegados em relação à pigmentação, isto é, manchas escuras contra o fundo despigmentado. Além desta característica, citologicamente esta variedade de milho apresentava duplicação no cromossomo nove (Comfort, 2001).

McClintock relacionou as mutações instáveis de pigmento com rearranjos cromossômicos, o estoque de milho que possuía um fenômeno citogenético de quebrafusão-ponte durante a divisão nuclear. Ao analisar estas quebras sofridas por marcadores heterozigotos no braço curto do cromossomo nove, verificou-se que a quebra ocorria hora num sítio e hora em outro. McClintock concluiu que ocorreriam unidades móveis, que seriam capazes de produzir quebras em diferentes locais do gene (McClintock, 1950; 1951a, b; 1958; 1961). As evidências genéticas da presença de elementos de transposição no genoma são fornecidas pelas mutações instáveis. A incisão imprecisa dos elementos de transposição e os rearranjos cromossômicos causados pelos transposons produzem derivativos que possuem fenótipos variados, desde o selvagem (reversão) até o pseudo-selvagem ou novos mutantes. O tempo em que um derivativo de uma mutação instável surge, está relacionado ao ciclo de vida do organismo, dependendo do estágio do desenvolvimento do mesmo (McClintock, 1951). McClintock, conclui com isto, que esta variação observada era proveniente de distintas unidades genética, sendo denominadas de Elementos Controladores, que poderiam mover-se de um sítio para outro, estes padrões de variações afetavam três ou mais genes 
simultaneamente. Este primeiro transposon descrito por Bárbara McClintock foi analisado em locos instáveis de milho, sendo isolado e caracterizado dois transposons, o "Activator" e o "Dissociation" (Ac/Dc) (Gierl at al., 1989).

Apesar dos Elementos de Transposição terem sido descritos inicialmente em Zea mays (eucarioto), foi em Escherichia coli (procarioto), que na década de 1960, os transposons ganharam destaque (Galas \& Chandler, 1989).

Na década de 1970, com o advento das técnicas de DNA recombinante e sequenciamento, os TEs puderam ser identificados e caracterizados molecularmente, e desde então, têm sido encontrados e pesquisados em diversos organismos: fungos como F. oxysporium (Daboussi \& Capy, 2003); animais com o Caenorhabditis elegans, Drosophila sp (Finnergan, 1985); plantas como Zea mays, Nicotiana tabacum (Döring \& Starlinger, 1986); e diversas bactérias como Staphylococcus aureus, E. coli, Pseudomonas putida, Rhizobium leguminosarum (Mahillon \& Chandler, 1998).

\subsubsection{Estrutura dos Elementos de Transposição}

Elementos de Transposição ou transposons são conjuntos de segmentos lineares de DNA capazes de alterar sua posição dentro do genoma, independentemente de homologia entre região genômica onde se encontram inseridos e o local a qual se destinam (Feschotte et al., 2002).

Há diversos grupos de elementos de transposição dispersos entre os mais diferentes organismos (procariotos e eucariotos), mas apesar da grande heterogeneidade destes elementos genéticos móveis, eles apresentam entre si algumas características em comum: 1. apresentam seqüências de nucleotídeos muito similares em ambas extremidades, sendo chamadas de seqüências terminais; 2. carregam genes que codificam enzimas especiais, cuja habilidade de transpor este seguimento linear de DNA; 3. ao se inserirem no genoma, criam pequenas regiões duplicadas no sítio alvo de inserção, chamadas de repetições diretas do DNA alvo, que podem ser visualizadas como segmentos iguais adjacentes a cada uma das repetições terminais do transposon; 4 . existem com múltiplas cópias no genoma (Craig et al., 2002). 
Os elementos de transposição são de grande interesse para a genética, sejam como ferramentas para experimentos, como DNA lixo (“junk”) e ainda como estudo para estrutura e evolução do genoma. Os TEs são classificados em duas classes, de acordo com seu tipo de transposição, RNA classe I ou DNA classe II (Figura 2) (Holmes, 2002).

Os Elementos da Classe I apresentam transposição via RNA e são conhecidos como retrotransposons e por retroposons. Os retrotransposons (Figura 3 a, b), apresentam uma forma muito similar aos retrovírus, sendo portadores de repetições terminais diretas, tão semelhante à organização desses vírus que são também chamados de LTRs (long terminal repeats), o qual, de maneira geral, apresentam um aspecto estrutural mais complexo. Suas seqüências apresentam TSD (short duplication) que são geradas durante a transposição no organismo hospedeiro. Os LTRs, que apresentam longas seqüências terminais diretas repetidas, flanqueiam um domínio interno que codifica proteínas análogas aos genes gag (capsídios dos vírus) e pol (protease, transcriptase reversa, e integrase) de retrovírus, a grande diferença entre os retrotransposons e os retrovírus é a ausência do gene env, responsável pela entrada do vírus pela membrana plasmática do hospedeiro, como exemplo de retrotransposon em fungos filamentosos podemos citar o tipo Gypsy e o tipo Copia. Os retroposons (Figura 3 c, d) são muito semelhantes a cópias de mRNA poliadenilados, que poderiam ter sido produzidas por transcrição reversa e inseridas no genoma, pelo modo similar a qual os retrovírus são integrados ao DNA celular. Diversos estudos realizados mostraram que de maneira geral os retroposons podem ser divididos em: seqüências LINE (long interspersed sequences or long interspersed nuclear sequences) e seqüências SINES (short interspersed sequences or short interspersed nuclear sequences) (Daboussi \& Capy, 2003). 


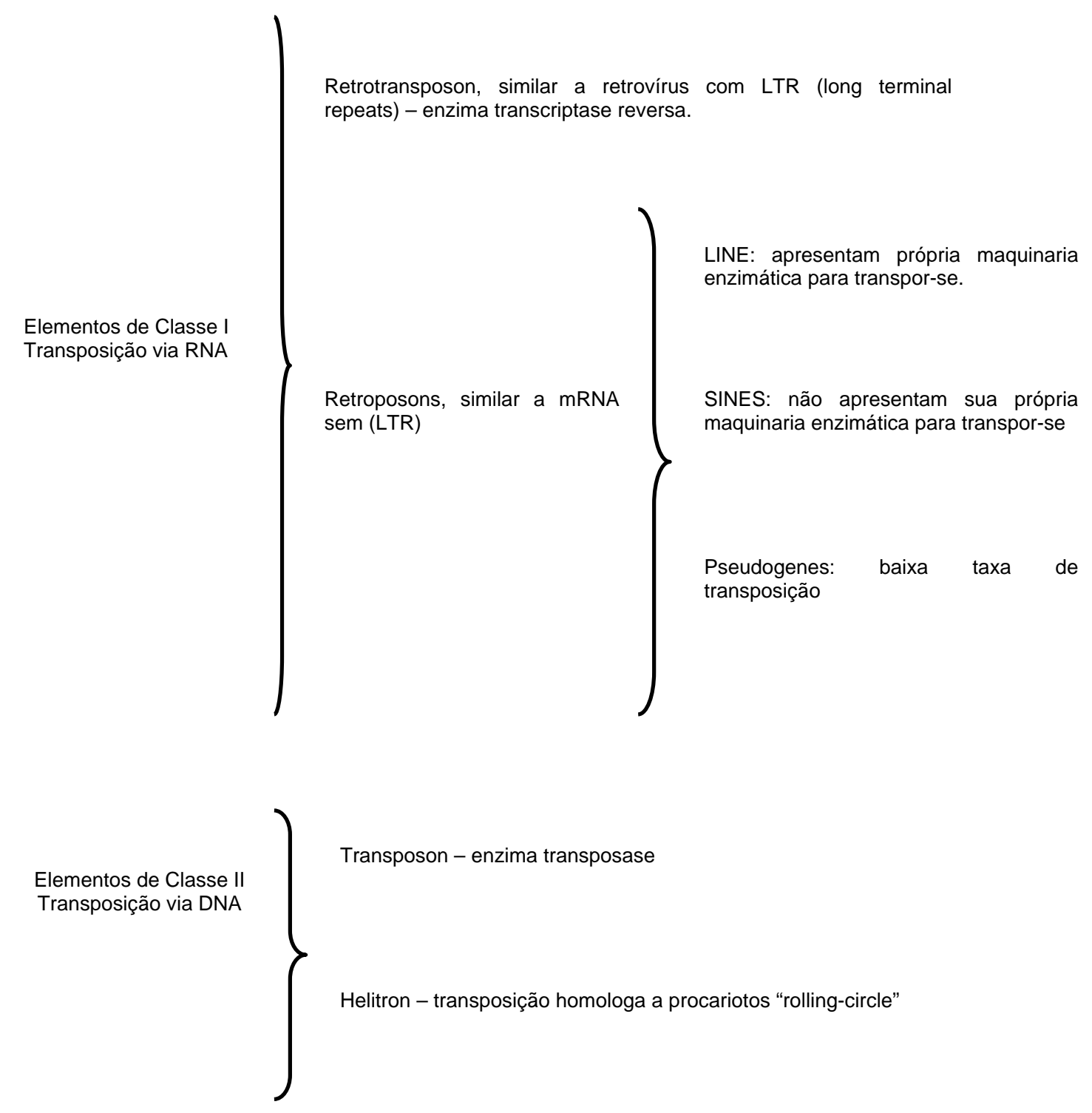

Figura 2 - Esquema da divisão de Classes dos Elementos de Transposição

Os Elementos da Classe II se transpõem via DNA (Figura 3 e, f, g) e, são conhecidos como transposons, são flanqueados por duas regiões terminais invertidas (TIRs). O mecanismo de transposição deste elemento é conhecido como "corta-cola" ("cut-and-paste") (Daboussi e Capy, 2003). Os transposons são caracterizados por curtas seqüências terminais repetidas invertida (TIRs ou IR) que margeiam uma mais ORF, que 
codificam uma transposase, enzima que é requerida para a sua transposição (Kempken \& Kuck, 1998a; Kempken e Kück, 2000; Windhofer \& Kempker, 2000).

Um novo tipo de Elemento de Transposição de Classe II foi encontrado e caracterizado em eucariotos, sendo denominados de Helitron (Plantas) e Heletron (vertebrados) (Kapitonov \& Jurka, 2001; Poulter et al., 2003). Os Helitrons apresentam o mecanismo de transposição semelhante aos encontrados em alguns procariotos. Este mecanismo é chamado de "círculo girando" ("rolling circle") transposição (RC transposição) (Mendiola et al., 1994; Pilar et al., 2001). As famílias dos Helitrons não geram sítios de duplicação e inserção, comum em todos os transposons de eucariotos, estes elementos apresentam curtas regiões duplicadas que são derivadas de regiões alvo do DNA que foram clivadas por atividades endonucleolíticas, por elementos como a transposase de outros TEs ou pela integrase. Os sítios alvo para os Helitrons são regiões ricas em dinucleotídeos $\mathrm{AT}$, e similarmente aos $\mathrm{RC}$ transposons de procariotos, os Helitrons não apresentam regiões terminais repetidas e invertidas, estes elementos, preferivelmente iniciam a cadeia 5' TC e terminam a extremidade 3' CTRR, contudo apresentam seqüências palindrômicas de 16 - 20 nucleotídeos a cima ("upstream”) da cadeia 3' CTRR (Feschotte \& Wessler, 2001).

Kapitonov \& Jurka (2001) sugerem que os Helitrons de Arabdopis thaliana, Oryza sativa e C. elegans, apresentam a capacidade de codificar um produto de mais ou menos 1500 aminoácidos, esta seqüência apresenta um domínio homologo a uma DNA helicase, com aproximadamente 500 aminoácidos, similar em procariotos, eucariotos e vírus. Este suposto produto apresenta em comum um motivo protéico “replicador-iniciador" muito semelhante aos RC de plasmídios e de alguns ssDNA de vírus. Estudos realizados por estes autores sugerem que este motivo conservado apresenta similaridade com a proteína "ssDNA-binding", extremamente conservada em plantas, animais e fungos, e a qual seria a responsável pelo mecanismo de replicação. No sistema de transposição de procariotos RC são necessários helicases, sintetizadas pelo hospedeiro e a "ssDNA-binding" para a transposição (Mizuuchi, 1992), como ocorre com os Helitrons (Figura 4 a, b). 
a. Retrotransposon - família Ty1- Copia

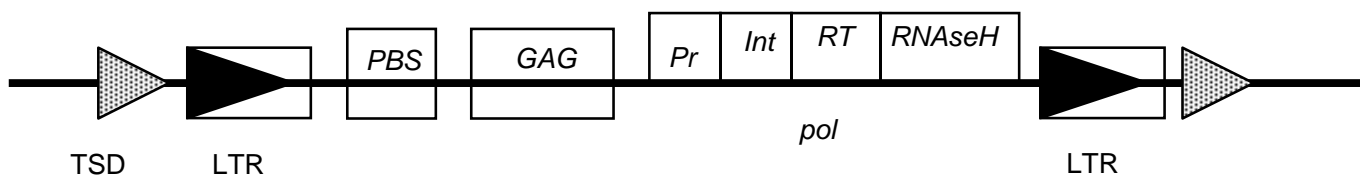

b. Retrotransposon - família Gypsy

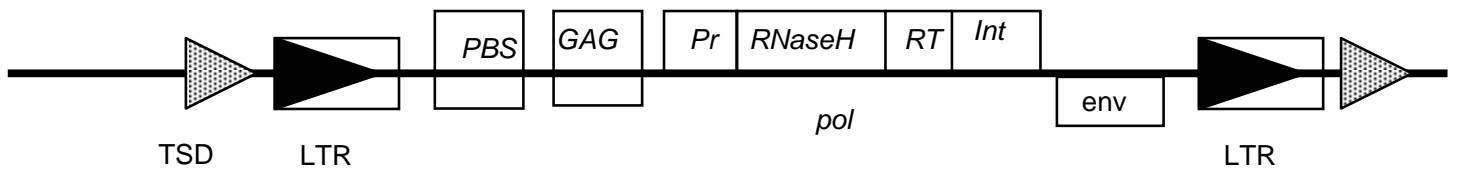

c. Retroposon - LINE-Like

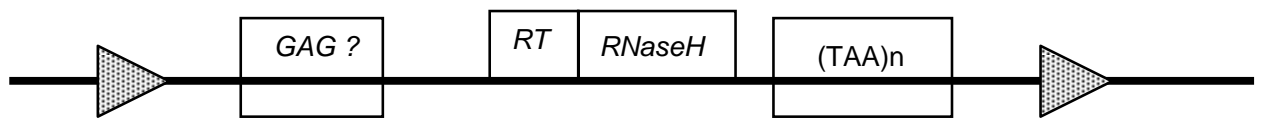

d. SINE like

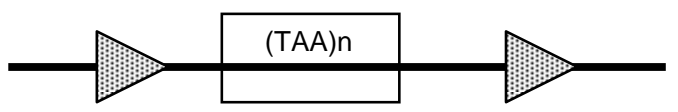

e. Transposon - família Pogo e Fot1

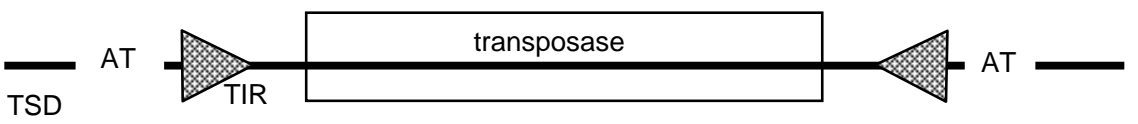

f. Transposon - família hAT

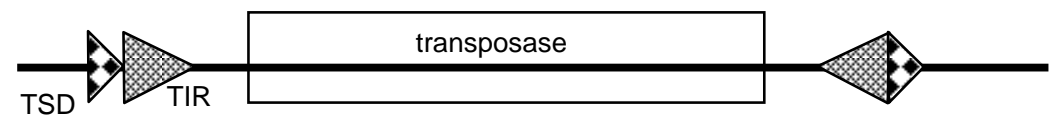

g. Mini-transposon Guest

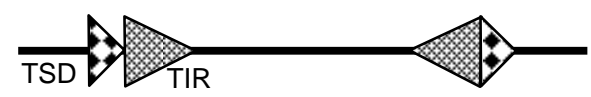

Figura 3 - Esquema de Elementos de Transposição em Fungos Filamentosos (Daboussi, 1996) 


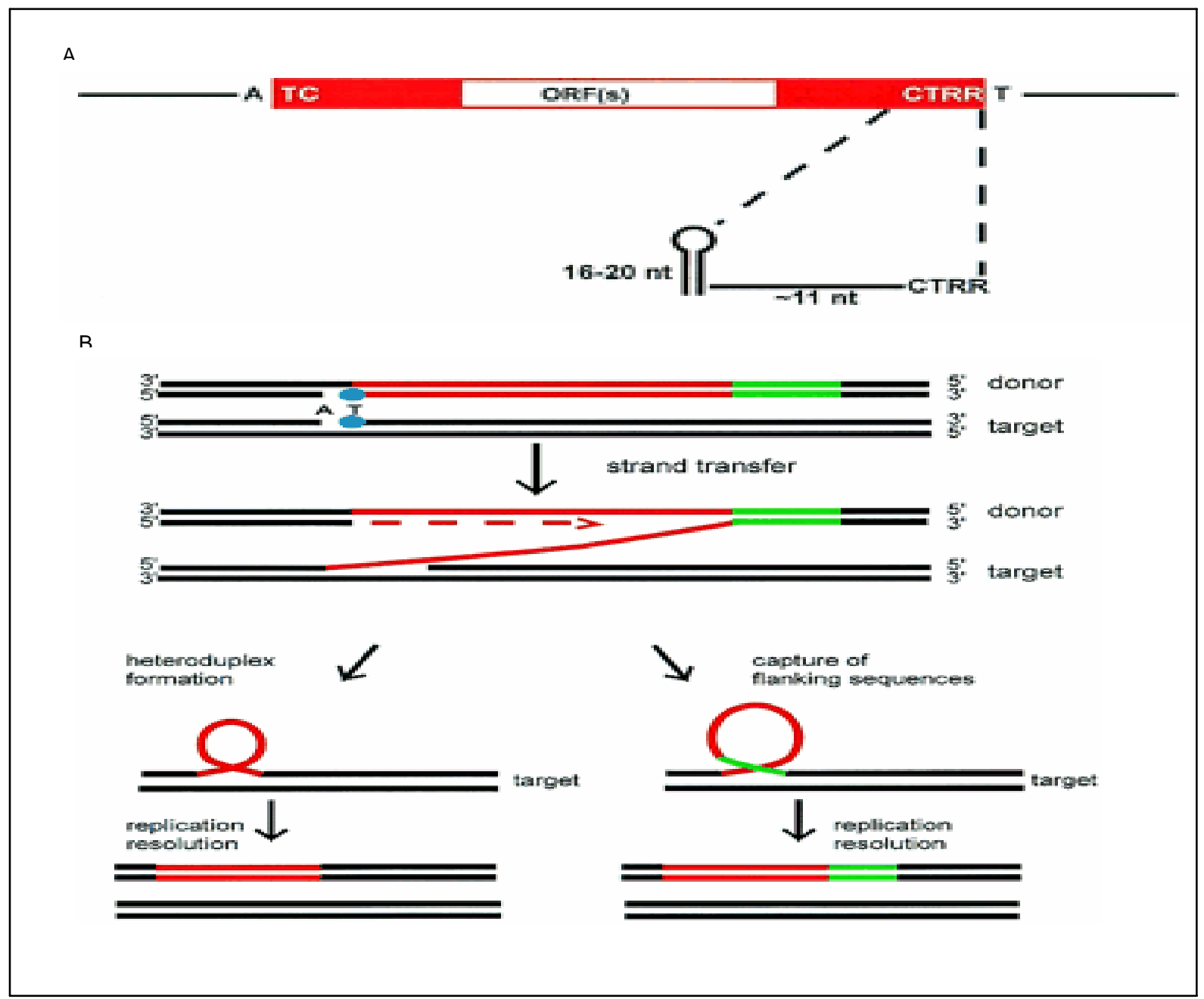

Figura 4 - Estrutura do elemento Helitron e o mecanismo de "rolling-circle" transposição. (a) Uma seqüência genérica de um Helitron mostrando aspectos da estrutura que pode ser requerida para a transposição, região 5' iniciando com AT e região terminal 3' com seqüência conservada CTRR que forma um estrutura palídrome "stem-loop", responsável pelo processo de transposição. (b) O mecanismo hipotético de transposição de um Helitron e aquisição de um gene, baseado no mecanismo "rolling circle" de procariontes. O elemento de transposição (vermelho) pode ser tanto autônomo como não autônomo. Duas moléculas de transposase (azul) clivam a região doadora e a receptora das fitas de DNA, ligando as fita no sentido 5' da receptora com 3' da doadora. A replicação e clivagem do sítio doador inicia com a região 3' $\mathrm{OH}$ livre e procede, deslocando uma da fitas do Helitron. Embora a estrutura palíndrome e a região 3' terminal do elemento são reorganizadas corretamente (figura a esquerda), a clivagem ocorre depois da seqüência CTRR e uma fita do Helitron é transferida para o sítio doador onde a replicação do DNA ocorre por um heteroduplex. A ilustração a direta descreve um caminho em que o DNA flanqueia a região 3' terminal de um elemento (verde) podendo ser transferido juntamente com o elemento do sítio doador. Esta pode ser a maneira que um Helitron possua para adquirir seqüências adicionais (Feschotte \& Wessler, 2001) 


\subsubsection{Detecção de Elementos de Transposição}

Diversos trabalhos mencionam diferentes estratégias bem sucedidas para identificar elementos de transposição em fungos filamentosos. Os TEs podem ser detectados por sondas heterólogas, mas esta estratégia requer sondas apropriadas para detectar apenas um tipo específico de TE (Kachroo et al., 1994). Uma segunda técnica utilizada é via PCR, a qual utiliza primers específicos de seqüências conservadas, como exemplo seqüências conservadas da transcriptase reversa (Favell et al., 1992; McHale et al., 1992; Voytas et al., 1992).

A terceira técnica é utilizar uma biblioteca genômica do fungo, e através de hibridizações diferenciais, localizar regiões altamente repetitivas no genoma (Kempken et al., 1995).

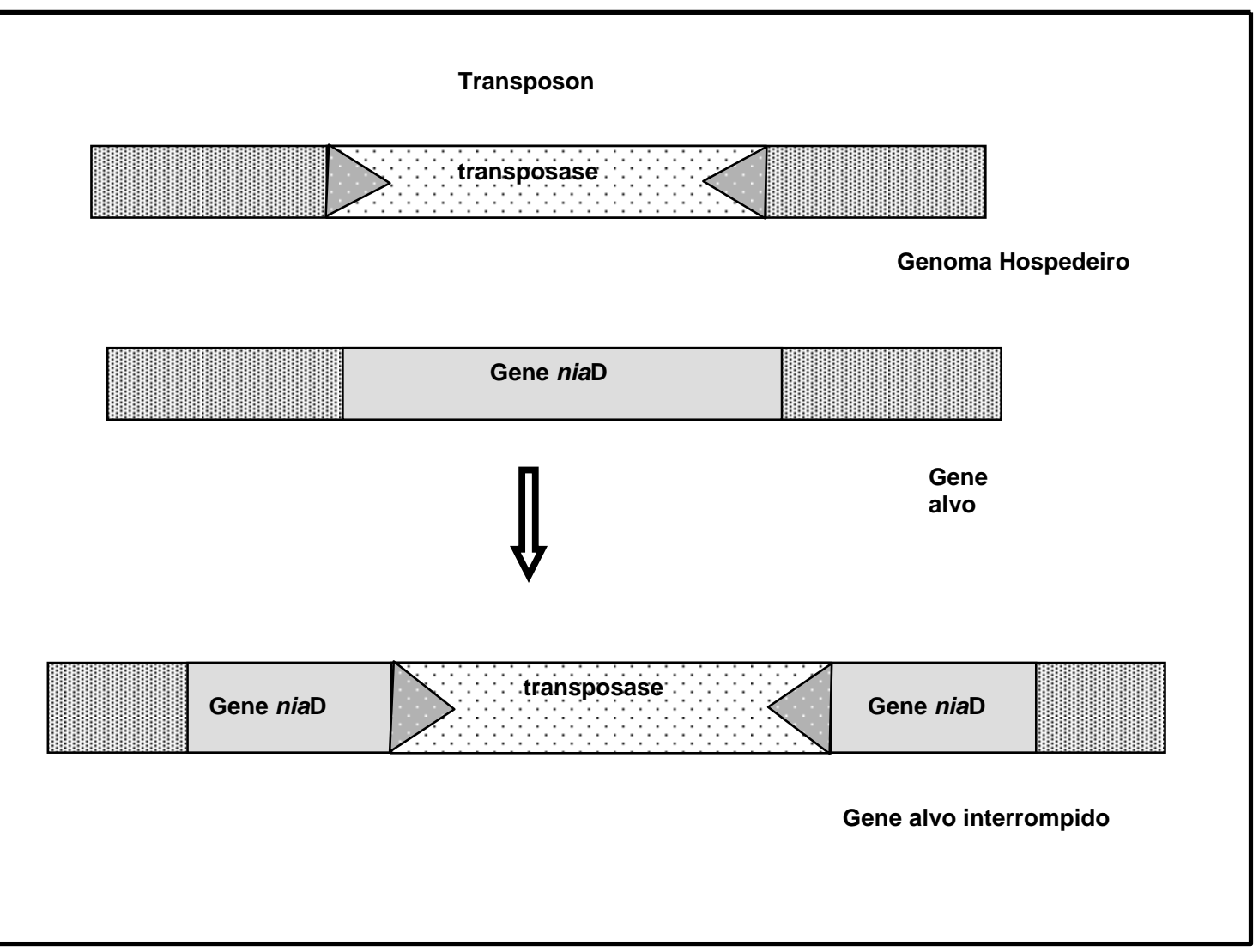

Figura 5 - Esquema de "transposon trap" 
A quarta técnica utilizada é "armadilha de transposon" ("Transposon trap") (Figura 5), na grande maioria dos casos os transposons são identificados como seqüências de inserção em um gene, como exemplo do gene da nitrato redutase (niaD) (Daboussi et al., 1992), levando a mudança fenotípica. O gene niaD é particularmente muito utilizado, devido à facilidade de obtenção de mutantes para nitrato redutase (Maurer et al., 1997), mas outros genes, de fácil fenótipo podem ser utilizados, como o gene am que ocasionou o isolamento do elemento Tad em N. crassa (Kinsey \& Helber, 1989).

\subsubsection{Importância do estudo dos Elementos de Transposição em Fungos Filamentosos}

A utilização de organismos simples, como fungos apresenta grandes vantagens para o estudo dos Elementos de Transposição, quando comparados a outros sistemas eucariotos.

As vantagens do estudo de Elementos de transposição em fungos filamentosos consistem: os fungos apresentam genomas pequenos, quando comparados dos animais e vegetais, em torno de $30-40 \mathrm{Mb}$. Os cromossomos podem ser separados em gel de eletroforese de campo pulsado ("pulsed field gel electrophoresis"), sendo utilizado ainda, analises com enzimas de restrição, favorecendo o estudo evolucionário do cariótipo de fungos (Kempken \& Kück, 1998). Muitos transposon são seqüências

repetitivas dispersas pelo genoma, e uma vez clonado, o transposon pode ser usado como um marcador polimórfico em segregações e em análises filogenéticas, podemos utiliza-los com técnicas de "RAPD”, "RFLP”, “AFLP” (como sondas específicas). Este tipo de aplicação é de interesse da indústria farmacêutica para analisar linhagens que sejam melhores produtores de algum fármaco. Na agronomia, o grande interesse é em identificar fitopatógenos específicos (Kempken, 1999). Em Tolypocladium inflatum, o elemento Restless está presente com no genoma com mais de 15 cópias, o que resulta num modelo muito específico para hibridização, sendo detectado em um pequeno número de linhagens (Kempken et al., 1998). 
Muitos fungos têm desenvolvido mecanismos de inativação de seqüências repetitivas, anterior ou durante a recombinação sexual. Por exemplo, o fenômeno "RIP" (Neurospora crassa - repeat-induced point mutation), envolvendo a metilação e hepermetilação de seqüências gênicas repetidas, isto causa a destruição de múltiplas cópias de elementos de transposição. "RIP” é a associado com substituição C - T em seqüências repetidas depois da metilação da citosina e "MIP" (Ascobolus immersus methylation induced premeiotically) envolvendo o silenciamento de múltiplas cópias de DNA repetitivo por metilação, este dois mecanismos silenciam elementos de transposição no genoma do fungo (Cambareri et al., 1989; Selker, 1990).

Em fungos filamentosos, diferentes dos outros organismos eucariotos, ocorre uma organização cenocítica, onde um grande número de núcleos está presente em um simples compartimento citoplasmático, o que altera a expectativa do impacto dos eventos de transposição no organismo. O estudo dos mecanismos de transposição é facilmente estudado em fungos, devido ao seu ciclo de vida rápido, além do que o mecanismo de transposição da classe II (transposons) não é muito bem definido em eucariotos. Em geral a transposição é replicativa, sendo que estes processos podem ser comprovados em fungos (Kempken \& Kück, 1996).

O estudo da transferência horizontal pode ser estudado utilizado sistema de transformação em fungos (Daboussi, 1996; Kempken \& Kück, 1998).

Outra importância do estudo dos TEs em fungos é a possibilidade de utilizá-los como ferramentas "gene tagging" (Daboussi \& Capy, 2003), onde transposons completos isolados de fungos filamentosos podem ser usados como agentes mutagênicos para inativação e clonagem de genes de interesse, como marcadores para a detecção de raças específicas de fungos fitopatógeno em tecidos de plantas infectadas, para estudo de fungos enteropatogênicos, no estudo da dinâmica de populações, evolução e transferência horizontal. 


\subsubsection{Elementos de Transposição em Fungos Filamentosos}

Os estudos sobre Instabilidade Genética em fungos tiveram início na década de 1950 com Roper (1952) e Pontecorvo et al. (1954). Os autores demonstraram que determinados sítios no genoma são mais sucessíveis a mutações espontâneas, existindo analogia entre instabilidade genética e mutações espontâneas em determinados alelos mutantes. Essa instabilidade pode ser considerada alelo específico, possuindo alta probabilidade de ocorrer uma mutação para um estado mais estável, sendo essa mutação independente de fatores externos.

Azevedo \& Roper (1970) estudando setores deteriorados e melhorados da linhagem A de A. nidulans, a qual apresenta duplicação cromossômica, gerando instabilidade mitótica (Bainbridge \& Roper, 1966; Nga \& Roper, 1968a, b), caracterizaram os setores produzidos como sendo morfologicamente instáveis. Os setores deteriorados apresentem uma taxa de crescimento menor em relação à linhagem duplicada sendo observada produção reduzida de conídios e variação no grau de pigmentação da colônia. Os autores sugerem que o caráter deteriorado é resultante da perda total ou parcial da duplicação cromossômica, com posterior inserção desse segmento em qualquer um dos oito grupos de ligação de A. nidulans, o que distingue e caracteriza cada um dos setores emitidos. Esse sistema de instabilidade é muito semelhante aos elementos de transposição de milho, bactérias e drosófilas, podendo ser considerado um relato de transposon em fungos. Mas apenas no final da década de1980 foram isolados os primeiros Elementos de Transposição em Fungos Filamentosos.

Kinsey \& Helber (1989) trabalhando com linhagens selvagens instáveis de Neurospora crassa chamada de Adiopodoumé, selecionaram mutantes espontâneos para o gene am (glutamato desidrogenase), este gene foi escolhido, pois já era clonado e bem conhecido a nível molecular, além de apresentarem mutantes facilmente selecionados. Em experimentos iniciais, as linhagens padrões foram ensaiadas, mas não houve indícios de mutações devido a elementos de transposição, utilizou então uma outra linhagem, na qual Newmeyer \& Galeazzi (1977) já haviam observado efeitos de instabilidade na linhagem Dp (IL:IR) H4250. Por meio de cruzamentos com linhagens 
lys1 (lisina), foram isolados alguns mutantes para am. Para detectar se as mutações foram causadas pela inserção de elementos de transposição, amostras dos DNAs mutantes foram submetidas à análise dos fragmentos de restrição para o loco am com sondas de fragmentos desse gene. Realizaram o sequenciamento das regiões deste gene, nos casos onde ocorreu a produção de diferentes bandas no gel de eletroforese. Através deste método, foi possível localizar dois elementos transponíveis, cuja inserção causou duplicação de 14 e 17 pb, constituindo uma mutação estável pela inserção na região codificadora de am e, uma segunda mutação instável localizada "upstream" do sítio de início da transcrição de am. O elemento de Transposição foi denominado de Tad. É interessante observar que vários fatos descritos por Newmwyer \& Galeazzi (1977), como quebras na linhagem Dp (IL; IIR) H4250, podem ser devido à recombinação entre elementos de transposição Tad dispersos no genoma. A partir do isolamento do Elemento Tad diversos TEs foram e continuam sendo isolados.

Ainda em N. crassa, Cambareri et al. (1994) clonaram e sequenciaram outro elemento de transposição denominado de Tad-1. A comprovação da atividade do elemento foi feita por meio de observação da sua habilidade de transpor-se em núcleos. O elemento Guest (Yeadon \& Catcheside, 1995), apresenta múltiplas cópias no genoma de $N$. crassa e uma grande homologia com o elemento Tourist de milho (Bureau \& Wessler, 1992). Bibbins et al. (1998) identificaram seqüências repetitivas de DNA em $N$. crassa, estas seqüências pertencem a família de retroelementos degenerados, sendo denominado de $D A B 1$.

Schmid-Berger et al. (1994) isolaram um elemento de transposição altamente repetitivo no genoma do fungo dimórfico Yarrowia lipolytica, o elemento Ylt 1. Este elemento assemelha-se a um retrotransposon encontrado em outros eucariotos. Ele possui cerca de 9,4 kb podendo ser transposto pelo genoma, além disto é flanqueado por uma longa repetição terminal (LTR), o elemento Zeta. Os autores isolaram e sequenciaram diversas cópias do elemento zeta. A seqüência deste elemento é bem conservada e possui cerca de $714 \mathrm{pb}$, sendo flanqueada pelos nucleotídeos 5' - TG .....CA - 3'a qual faz parte de uma pequena seqüência repetida e invertida, uma característica conservada nos LTRs dos retrovírus e retrotransposon. 
Com a descoberta do elemento de transposição Restless em T. inflatum (Kempken et al., 1995; Kempken \& Kück, 1996), observou que eu mecanismo de transposição era muito semelhante ao mecanismo "Activator" em milho, membros desta família de transposons são bem conhecidos em plantas, animais e humanos. Em fungos o elemento Restless apresenta 20 pb de seqüências repetidas, invertidas e terminais (ITRs), além de 8 pb de sítio específico de duplicação ( $h A T$ específico), com tamanho total de $4.1 \mathrm{~kb}$, e esta presente na linhagem ATCC34921 de T. inflatum com o total de 15 cópias espalhadas pelo genoma. Um aspecto muito interessante deste elemento de transposição é a presença de um "splicing" alternativo no intron, mecanismo muito raro em fungos. Kempken \& Kück (1998a) e Kempken et al. (1998b) demonstraram que a atividade Restless em T. inflatum é caracterizada por sítios de integração. Os sítios aparentemente são flanqueados por 8 pb e sua ocorrência está relacionada diretamente com o evento de transposição, além disto são identificados transposons circulares que podem agir como intermediários ou como produtores dos processos de transposição. Kempken \& Kück (2000) utilizaram a técnica de "gene tagging" com Restless, para identificar e caracterizar o gene regulador da nitrato redutase em T. inflatum. Este foi o primeiro exemplo de "gene tagging" em fungos filamentosos. Em N. crassa, processo semelhante foi realizado utilizando a excisão do transposon Restless para provocar processo de metilações em regiões específicas de $N$. crassa (Windhofer et al., 2000).

Maurer et al. (1997) isolaram um elemento de transposição do fungo entomopatogênico Beauveria bassiana, utilizando a técnica de "gene trap" para o gene da nitrato redutase, clonado deste fungo. O elemento foi denominado de Hupfer e apresenta o tamanho total de 3336 pb com 30 pb imperfeitas invertidas nas seqüências terminais.

O fungo fitopatógeno Magnaporthe grisea apresenta um grande número de elementos de transposição. Kachroo et al (1994) clonaram e caracterizaram um elemento de transposição em Magnaporthe grisea, o Pot, esse elemento possui um tamanho de $1857 \mathrm{pb}, 43 \mathrm{pb}$ de perfeitas seqüências terminais repetidas e invertidas (ITRs). O retrotransposon MAGGY (Tosa et al., 1995; Farman et al., 1996a) possui o 
tamanho de aproximadamente 2539 pb, e apresenta 42 cópias distribuídas pelo genoma, sendo que $75 \%$ destas cópias estão em um único local no genoma (Nitta et al., 1997).

Em M. grisea diversas famílias de transposons e retrotransposons tem sido identificadas. Isto inclui ambos retrotransposons que se transpõem completamente por intermédio da transcriptase reversa e os transposons (ITR) que se transpõem diretamente pela transposase, nesta categoria destacam-se Pot2 e Pot3 (Farman et al., 1996a; Kachroo et al., 1994). O genoma de M. grisea contém ambos LTR ("long terminal repeat") e os não-LTR. Três deferentes famílias de não-LTR, incluindo uma LINE ("long interspersed nuclear element") e duas SINEs ("short interspersed nuclear elements”) são identificadas (Hamer et al., 1989; Kachroo et al., 1995; Sone et al., 1993; Valent \& Chumley, 1991). O número de cópias de LINE MGR583 (ou MGL) é extremamente alta nos fungos fitopatógenos, mais de 50 cópias e é muito variada em linhagens não fitopatogênicas (Hamer et al., 1989). A primeira seqüência SINE identificada, MGSR1, apresenta mais de 40 cópias no genoma dos fitopatógenos e apenas 1 seqüência no genoma dos não fitopatógenos. Outra seqüência SINE, Mg-SINE, foi identificada como uma inserção dentro do transposon Pot2 (Kanchroo et al., 1995).

Duas diferentes famílias de LTR retrotransposon, grass-hopper (grh) e MAGGY, pertencente à classe Gypsy, são identificadas em M. grisea (Dobinson et al., 1993; Farman et al., 1996b). A distribuição dos elementos de transposição no genoma de M. grisea é muito variada, mas Kang (2001), descreveu que os elementos Pot2, MgSINE e um novo elemento LTR descrito, o MGLR-3, e estão localizados preferencialmente nas regiões teloméricas de linhagens de $M$. grisea fitopatogênicas, podendo causar quebra e transposição cromossômica.

Nishimura et al. (2000) trabalhando com linhagem de $M$. grisea que apresentavam a seqüência de um retrotransposon tipo LINE, o $M G L$, observaram que este elemento de transposição inseriu-se em um gene estrutural para o desenvolvimento do conidióforo. Realizados o isolamento e o sequenciamento deste gene, verificou uma homologia grande com o gene medusa (med) de A. nidulans, este trabalho foi o primeiro a relatar a influência dos elementos de transposição em genes de desenvolvimento. 
Os Elementos de Transposição do fungo filamentoso e fitopatogênico Fusarium spp são extremamente estudados. O elemento Fot1 foi isolado por Daboussi et al. (1992), esses autores analisaram mutantes niaD instáveis isolados de um transformante de F. oxysporum com o gene da nitrato redutase de A. nidulans. Esse transposon foi identificado como um inserção no gene da nitrato redutase de dois desses mutantes. Fot1 (Daboussi et. al., 2002) possui 1928 pb de comprimento, incluindo ITRs de $44 \mathrm{pb}$. Uma unidade de transcrição foi identificada ocupando a maior parte do elemento. Esse mRNA de 1,6 kb codifica um polipeptídeo de 542 aminoácidos.

O transposon Fot2 foi inicialmente identificado como um inserto de 2,1 kb no gene niaD de uma linhagem sem Fot1 (Daboussi \& Langin, 1994). Mais tarde, usando essa inserção como sonda, Daboussi \& Langin (1994), identificaram seqüências hibridizando Fot2 (em torno de 15 seqüências) em uma linhagem F24 contendo cerca de 100 cópias de Fot1. Sequenciamentos realizados com estes elementos indicam que ele possui ITRs perfeitos que se estendem por pelo menos $66 \mathrm{pb}$ com 25 pb igualando-se aos ITRs do Fot1. Esses autores consideraram que essa similaridade relativa indica que o Fot1 e Fot2 são relacionados.

De acordo com Daboussi \& Langin (1994), os elementos Fot1 e Fot2 (Kimura \& Yamaguchu, 1998), bem como os elementos Impala e Hop, lembram transposons bacterianos, sendo, portanto transposons de Classe II. Esses elementos compartilham a mesma estrutura básica, isto é, duas repetições terminais invertidas (ITRs) de 27 a 96 pb de comprimento, flanqueando uma região central assumida por codificar uma transposase. Eles são flanqueados por uma duplicação direta (2 a 7 pb) da seqüência hospedeira (o sítio alvo). Ainda segundo esses autores, esses elementos devem ser divididos em dois grupos. Os elementos Fot1, Fot2 e Impala (Hua-Van et al., 1998 e 2001) onde se inserem em sítios TA que aparece duplicado após a inserção. Já o elemento Hop possui comportamento completamente diferenciado.

O elemento Impala foi isolado e caracterizado por Langin et al. (1995), este elemento possui $1.280 \mathrm{pb}$ e ITRs de 27 pb. A família Impala está presente em um baixo número de cópias (aproximadamente 6) e são altamente polimórficos, uma situação que não ocorre em Fot1. A cópia Impala-160 seqüenciado parece ser trans- 
defectiva, por causa da presença de dois "frameshifts" requeridos para obter uma proteína completa, entretanto é cis-ativa. O transposon Impala, da mesma forma que Fot1, Fot2 e Hop, foi isolado de um mutante instável para a nitrato redutase.

O elemento Hop possui 3,5 kb com ITRs perfeitos de $96 \mathrm{pb}$, e produz uma duplicação de 7 pb no sítio alvo de inserção no gene niaD (Daboussi \& Langin, 1994; Chalvet et al., 2003).

Anaya \& Roncero (1995), isolaram e caracterizaram um retrotransposon do fungo F. oxysporum f. sp. lycopersici. O elemento, designado skippy (skp) possui 7,8 $\mathrm{kb}$, sendo flanqueado por seqüências terminais longas idênticas (LTR) com 429 pb mostrando características estruturais de retrovírus e retrotransposon LTRs.

Em Fusarium spp, ocorrem também elementos de transposição pertencentes à classe I. O elemento Forest (Julien et al., 1992) é caracterizado por ser um LTR retrotransposon. Este elemento apresenta um pol de genes (transcriptase reversa, protease, ribonuclease $\mathrm{H}$ ). A integrase não é identificada em Forest, demonstrando ser um elemento incompleto (Daboussi e Langin, 1994). O retroelemento Palm, consiste de uma seqüência semelhante a um LTR retrotransposon, este elemento é isolado apenas no genoma de F. oxysporum, fitopatógeno de azeite de dendê (Mouyna et al., 1996).

Glayzer et al. (1995) isolaram um elemento de transposição do fungo $A$. niger (linhagem N402). O elemento foi identificado como uma seqüência inserida na região codificadora do gene da nitrato redutase. Ele estava inserido no sítio TA e duplicou o sítio alvo na inserção. O elemento isolado tinha cerca de 4.798 pb de comprimento e continha $37 \mathrm{pb}$ de imperfeitas repetições terminais invertidas (ITRs). A seqüência central do elemento revelou um quadro de leitura aberto denominado ORF1, que mostrou similaridade, ao nível de aminoácidos para a transposase da classe de transposons DNA TC1 mariner. Uma outra seqüência dentro da região central do elemento mostrou similaridade com a região codificadora 3'e região abaixo não traduzida do gene amyA de A. niger. O elemento Ant 1 está aparentemente presente como uma cópia única na linhagem N402 de A. niger. 
Os elementos de Transposição Tan1 e Vader foram isolados do fungo A. niger var awamori (Amutan et al., 1996; Nyyssönen et al., 1996). Vader foi identificado através do "screening" de mutantes para nitrato redutase. Este elemento apresenta 437 $\mathrm{pb}$, sendo flanqueado por $44 \mathrm{pb}$ repetidas e invertidas, e apresenta aproximadamente $2 \mathrm{a}$ 15 cópias no genoma de A. niger var awamori. O elemento Tan1 foi isolado a partir de uma biblioteca genômica e está presente em uma simples cópia nogenoma. Tan1 apresenta um ORF que codifica uma transposase homologa aos elementos Fot1 de F. oxysporum e Pot2 de M. grisea.

As pesquisas sobre elementos de transposição em A. nidulans tiveram início com os estudos sobre a Instabilidade Mitótica, e pode ser dividida em três linhas de pesquisas. A primeira envolve as aberrações cromossômicas estruturais como a própria causa da instabilidade, a segunda linha que ocorre paralelamente à anterior refere-se as aneuploidias, e a terceira linha teve uma maior abertura a partir de 1970, com os fatores que alteram a instabilidade, para melhor compreender o processo que envolve a chamada "não conformidade mitótica” (Nga \& Roper, 1966).

A instabilidade mitótica de A. nidulans foi estudada inicialmente sob o enfoque das aberrações cromossômicas, especificamente duplicações. Bainbridge \& Roper (1966) foram os primeiros a descrever novas características entre a progênie de cruzamentos de pais morfologicamente normais. Este novo tipo, apresentando menor taxa de crescimento e segregações em proporção constantes foram designadas de “crinkled" (enrugado) e carregava uma duplicação como resultado de uma translocação desigual de um dos parentais. Nga \& Roper (1968a, b), introduziram definitivamente os estudos de instabilidade mitótica em A nidulans, com a descrição de uma linhagem bastante interessante originada do cruzamento I ad bi / I $\rightarrow$ II ad bi X pro paba y, onde foram selecionados recombinantes verdes enrugados com provável genótipo I pro paba y $\mathrm{ad}^{+}$bi / I $\rightarrow$ II y $a d^{+}$bi. Esta linhagem apresenta marcas genéticas no segmento duplicado, tornando fácil a detecção de deleções pela simples observação da coloração dos setores. As colônias de linhagens com duplicação produziram freqüentemente dois tipos de setores. Uma classe de variantes fenotipicamente melhorados e uma segunda classe observada com menor freqüência, com o fenótipo deteriorado. Variantes 
melhorados resultam de prováveis perdidas do segmento duplicado e os variantes deteriorados por novas duplicações em tandem. Para explicar as deleções propuseram um mecanismo de crosssing-over dentro de um laço intracromossomo e, tentativamente como uma fonte de elementos de transposição. Nga \& Roper (1966), com o uso de linhagens normais, translocada e duplicada, demonstraram que o surgimento de setores melhorados era exclusivamente devido à duplicação, uma vez que a normal e translocada não apresentavam setores.

Outro trabalho que associa instabilidade, com efeito de posição foi feito por Clutterbuck (1970a, b), com mutantes para o loco "bristle", onde o conidióforo permanece como uma hifa rígida ao invés de desenvolver uma vesícula, esterígma e conídios. O alelo brl deste loco apresenta um fenótipo variegado, e a análise genética deste variante sugeriu uma translocação, dando a idéia de que o final do cromossomo III é heterocromático e a associação deste com o segmento eucromático do grupo de ligação VIII causa a variegação do loco $b r l$.

Em 1970, surge o primeiro trabalho que utiliza o termo transposição em fungos (Azevedo \& Roper, 1970). Os autores observaram que os setores deteriorados, originados de linhagens duplicadas, poderiam ocorrer devido a novas duplicações em tandem ou à transposição do determinante de deterioração. A proposta de transposição envolve perda de uma mutação de seu sítio original, resultando em várias alterações morfológicas e, em substancial aumento de estabilidade. A maior parte dos variantes deteriorados analisados apresentou mutações em partes não duplicadas do genoma, segregavam como genes simples e foram designados de determinantes de deterioração. Mais uma vez é ressaltado a semelhança desse sistema de instabilidade com os elementos de transposição do milho (Ac/Dc), bactérias e Drosophila. Enfatizando que uma característica comum a esse caso de instabilidade é a conhecida ou possível presença de material genético em duplicata.

Em A. nidulans, várias tentativas tem sido realizadas para encontrar elementos de transposição (Stahl \& Tudzynski, 1992), mas até a década de 1990 nenhum elemento de transposição havia sido relatado. A descoberta do primeiro elemento de transposição em A. nidulans foi realizada pelo sequenciamento de um cosmídio do 
cromossomo VIII, o qual apresentou uma região com características de transposon (Elemento de Classe II), mas inativo (Kupfer et al., 1990).

Nielsen et al (2001) descreveram dois retrotransposons neste fungo, o Dane1 e o Dane2 (ㅁegenerated Aspergillus nidulans element). Este retrotransposon foi isolado próximo a região centromérica do cromossomo IV. O modelo de degeneração que este retrotransposon apresenta, sugere um processo muito similar ao fenômeno RIP (repeat-induced point-mutation).

Gems et al. (1991) estudando um plasmídio (Arp1) que apresentava alta freqüência de transformação, identificaram um fragmento de inserção de aproximadamente $6,1 \mathrm{~kb}$, denominado de $A M A 1$ esta seqüência é derivada de um segmento do cromossomo IV. Este plasmídio, também apresentava alta freqüência de recombinação em outros fungos como A. niger e A. oryzae. Aleksenko \& Clutterbuck (1996 e 1997) isolaram outras seqüências AMA1 de uma biblioteca genômica de $A$. nidulans. Os autores demonstraram que esta seqüência apresenta uma região invertida e duplicada, e com muitas outras cópias espalhadas pelo genoma. Esta seqüência,

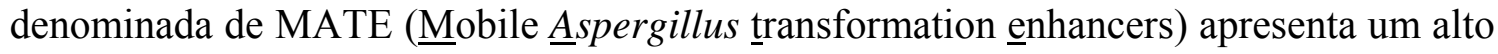
grau de similaridade com seqüências características de elementos de transposição, incluindo uma seqüência potencial Met-tRNA similar a encontrada em retrotransposon do grupo Ty-copia. Esta seqüência de nucleotídeo não é encontrada em toda a extensão de MATE, mas uma pequena seqüência "Spe-motif" é descrita simetricamente e duplicada por toda seqüência MATE. O motivo "Spe" consiste de um sítio de reconhecimento de topoisomerase I, além de apresentar um sítio alvo ilegítimo de eventos de recombinações.

Clutterbuck (2004) isolou cinco elementos MATE de linhagens de $A$. nidulans dos estoques do laboratório de Glasgow. Os elementos isolados foram denominados de MATE 1a e MATE $1 \mathrm{~b}$ encontrados no cromossomo IV, MATE 4 encontrado no cromossomo VI, MATE 5 encontrado no cromossomo I e MATE 9 encontrado no cromossomo VII. O elemento MATE é caracterizado por alguns aspectos: primeiro um sítio alvo de duplicações com 9-10 pb; segundo, é encontrado por todo o elemento alta freqüência de clusters "Spe-motif" com seqüência consenso 
RWCTAGWYNNN (onde $\mathrm{R}=$ purina, $\mathrm{Y}=$ pirimidina; $\mathrm{W}=\mathrm{A}$ ou $\mathrm{T}$ e $\mathrm{N}$ outras bases); terceiro, a seqüência MATE apresenta uma estrutura palíndrome "stem-loop".

Um fato muito importante que ocorre nos elementos MATE, é que não apresentam seqüências características de transposase, sendo seu mecanismo de transposição desconhecido (Clutterbuck, 2004). Supõe-se que as seqüências repetidas "Spe-motif" podem ser reconhecidas como sítios que funcionem como uma transposase durante a duplicação - quebra - transposição das seqüências. Esse modelo de transposição sugere um paralelo com os helitrons (Kapitov \& Jurka, 2001), onde estes transposons não apresentam transposase, seu modo de transposição ocorre por "rolling circle replication". "Rolling-circle" (RC) transposon foi descrito em transposons bacterianos IS91, IS801 e IS1294 (Mendiola et al., 1992; Richter et al., 1998; Tavakoli et al., 2000). Nos transposons "Rolling-circle" (RC) é codificada apenas uma proteína, similar a proteína iniciadora da replicação (REP) também conhecida com RC replicon. Usualmente a replicação de RC replicon é catalizada pela atividade de nucleases e helicases ativadas por REP e são ajudadas pelas DNAs helicases e ssDNA proteínas (SSBs) do hospedeiro. Este tipo de transposição, RC replicons, tem sido relatada em eucariotos com A. thaliana, O. sativa e C. elegans, e foi denominado de transposons helitrons (Kapitov \& Jurka, 2001).

\subsection{Objetivos}

A Instabilidade Genética em fungos tem se tornado cada vez mais freqüente e pode estar relacionada com a presença de material cromossômico em excesso, fatores citoplasmáticos, transposição de segmentos duplicados entre outros. Um caso clássico de Instabilidade Genética em Aspergillus nidulans, gerada por um segmento do cromossomo I duplicado e translocado para o cromossomo II (linhagem A), leva a formação de setores deteriorados e melhorados. Nos setores melhorados ocorre a perda da duplicação, já nos setores deteriorados ocorre a transposição da duplicação para um dos oito grupos de ligação. Este evento de transposição é muito semelhante aos 
descritos em elementos de transposição de bactérias, drosófilas e outros fungos filamentosos. Além disto os setores deteriorados apresentam alterações morfológicas em todo o ciclo de vida de $A$. nidulans.

Em função do exposto, o presente trabalho foi realizado visando ampliar as informações sobre esse tipo de instabilidade objetivando: analisar novos setores deteriorados com a finalidade de localizar geneticamente o determinante de deterioração ou segmento de inserção nos cromossomos; analisar citologicamente as possíveis alterações que podem ocorrer durante as fases iniciais do desenvolvimento, incluindo alterações no ciclo celular e migração nuclear; analisar a linhagem A e seus variantes deteriorados por técnicas moleculares para esclarecer se o determinante de deterioração ou segmento de inserção se trata de um elemento de transposição. 


\section{MATERIAL E MÉTODOS}

\subsection{Linhagens de Aspergillus nidulans utilizadas}

a. Linhagem A - com os marcadores genéticos: pro $\mathrm{A}_{1}, p a b a \mathrm{~A}_{6}$ e o segmento duplicado do cromossomo I e translocado para o cromossomo II (Nga \& Roper, 1968a).

b. Linhagem MSE - com os marcadores genéticos: $w_{3}$, fac $\mathrm{A}_{303}$, gal $_{1}$, $y \mathrm{~A}_{1}$, pyro $\mathrm{A}_{4}, \mathrm{sB}_{3}$, nic $\mathrm{B}_{6}$ e ribo $\mathrm{B}_{2}$ (McCully \& Forbes, 1965).

c. Linhagem $\operatorname{proA}_{1}, \operatorname{paba\mathrm {A}}_{6,}, y \mathrm{~A}_{2}$

d. Variantes deteriorados isolados da linhagem A: V5 (Azevedo \& Roper, 1970) V101, V102, V103 e V104 (Giancoli, 2000), com os marcadores genéticos: proA $_{1}$, paba $_{6}$ e o determinante de deterioração.

e. Linhagem G125 - com os marcadores genéticos bi $\mathrm{A}_{1}$, niaD15

f. G0248 - com os marcadores genéticos: biA 1 , brlA42 (mutante variegado, temperatura sensível - normal a $28^{\circ} \mathrm{C}$ e mutante a $37^{\circ} \mathrm{C}$ (Clutterbuck, 1969) (Anexo A).

As linhagens A e MSE são derivadas da linhagem selvagem de $A$. nidulans, originárias do Departamento de Genética da Universidade de Glasgow, Escócia, e foram cedidas pelo Departamento de Genética da Universidade de Sheffield, Inglaterra. A linhagem G125 foi gentilmente cedida pela Profa. Dra. Nilce Martinez Rossi da Faculdade de Medicina de Ribeirão Preto - USP. A linhagem G0248 foi gentilmente cedida pelo Prof. Dr. A. J. Clutterbuck da Universidade de Glasgow Escócia. Todas essas linhagens fazem parte do estoque de fungos do Laboratório de 
Genética de Microrganismos Prof. Dr. João Lúcio de Azevedo, do Departamento de Genética, ESALQ/USP, Piracicaba, SP.

Tabela 1. Grupos de Ligação e Marcadores Genéticos das linhagens de A. nidulans utilizadas

\begin{tabular}{ccc}
\hline Grupo de Ligação & Sigla do Marcador Genético & Marcador Genético \\
\hline I & suAladE20 & Supressor do mutante adE20 \\
I & proA1 & Requer prolina \\
I & biA1 & Requer biotina \\
I & pabaA6 & Requer ácido $\rho$-aminobenzóico \\
I & yA2 & Conídios amarelos \\
II & ade20 & Requer adenina \\
II & biA1 & Requer biotina \\
II & wA3 & Conídios brancos \\
III & galA1 & Incapacidade de utilizar galactose \\
IV & pyroA4 & Requer piridoxina \\
V & facA303 & Incapacidade de utilizar acetato \\
VI & sB3 & Requer tiossulfato de sódio \\
VII & nicB6 & Requer ácido nicotínico \\
VIII & riboB2 & Requer riboflavina \\
VIII & niaD15 & Incapacidade de utilizar nitrito \\
VIII & MrlA42 & Mutante bristle \\
\hline & & \\
\hline
\end{tabular}

\subsection{Técnicas de Análise Genética}

\subsubsection{Obtenção de heterocários}

Para obtenção de heterocários (análise genética via ciclo sexual e parassexual), foram adicionados conídios das linhagens a serem cruzadas (aproximadamente $10^{7}$ de conídios $/ \mathrm{mL}$ ) em tubos de ensaio, contendo $4 \mathrm{~mL}$ de meio 
mínimo acrescido de $4 \%$ de meio completo. A incubação foi realizada por 72 horas a $37^{\circ} \mathrm{C}$.

\subsubsection{Isolamento de diplóides (Roper, 1952)}

O isolamento dos diplóides foi realizado após a obtenção da película heterocariótica (3.2.1.), que foram transferidas para placa de Petri contendo meio mínimo sendo incubada durante sete dias a $37^{\circ} \mathrm{C}$. Após esse período, os conídios foram coletados com auxílio de uma alça de platina e colocados em um tubo de ensaio com tween 80 , a fim de se obter uma concentração de $1 \times 10^{7}$ conídios $/ \mathrm{mL}$. Essa suspensão de conídios foi diluída várias vezes e semeada em meio mínimo.

Os conídios, que germinaram no meio mínimo eram diplóides ou colônias heterocarióticas. As colônias provenientes de conídios heterocatióticos possuem um fenótipo característico, podendo ser facilmente distinguidas das colônias provenientes de conídios diplóides. Os critérios utilizados para caracterização de diplóides foram: a primeira pela capacidade das colônias diplóides de crescerem em meio mínimo através de susceptíveis repicagens, sendo possível uma vez que as linhagens parentais possuem marcadores auxotróficos complementares; o segundo critério foi à média do diâmetro dos conídios diplóides das linhagens analisadas nos cruzamentos. Segundo Roper (1952), a proporção do tamanho entre conídios haplóides e diplóides é de aproximadamente 1:1,3.

\subsubsection{Haploidização (Pizzirani-Kleiner et al., 1998)}

A obtenção de segregantes a partir de diplóides ocorre espontaneamente durante as susceptíveis repicagens, isto devido a perdas cromossômicas espontâneas que ocorrem durante as divisões mitóticas (Kafer, 1960; Clutterbuck, 1996). Para acelerar o processo de haploidização, diversos agentes químicos e físicos têm sido testados. Os agentes mais utilizados são os químicos, onde se destacam: $\rho$ - fluorfenilalanina ( $\rho$ FA)(Morpurgo, 1961; Lhoas, 1961), benomil (Hastie, 1970), cloroneb (Paccola, 1982) e N-glycosyl polifungin (Bal et al, 1975). Os agentes haploidizantes agem na divisão mitótica, provocando a perda de grupos de ligação das duas linhagens ao acaso. Neste 
trabalho foi utilizado $\rho$ - fluorfenilalanina ( $\rho$-FA) na concentração de $0,08 \mathrm{mg} / 30 \mathrm{~mL}$ de meio de completo. $\mathrm{O} \rho \mathrm{FA}$ foi adicionado à placa de Petri com meio completo, e o diplóide selecionado foi incubado por um ponto central. Os setores haplóides gerados no processo de haploidização foram purificados por estria em meio completo, no mínimo 2 ciclos de incubação à $37^{\circ} \mathrm{C}$ por 5 dias. As colônias haplóides selecionadas foram transferidas para placa mestra com 26 pontos (meio completo) e foram testadas para todos os marcadores genéticos envolvidos na análise mitótica, com auxílio de um replicador multifio (Azevedo et. al., 1976). As leituras da análise genética foram efetuadas após 24,48 e 72 horas de crescimento a $37^{\circ} \mathrm{C}$.

\subsubsection{Análise Meiótica por meio Ciclo Sexual (Pontecorvo et. al., 1953)}

Para indução do ciclo sexual, os heterocários foram preparados como descritos no item 3.2.1., sendo as placas de Petri vedadas com fita adesiva. Após 10 dias de incubação a $37^{\circ} \mathrm{C}$, as placas foram analisadas sob microscópio estereoscópio para verificar a presença de corpos de frutificação, os cleistotécios. Foram selecionados os cleistotécios maiores e mais escuros, os quais foram "rolados" em placa de Petri contendo ágar e água destilada e esterilizada, para a retirada de células adjacentes, as células hülle. Os cleistotécios escolhidos e limpos foram transferidos para tubo de ensaio contendo solução Tween 80 . Os cleistotécios foram esmagados contra a parede do tubo, com ajuda de uma pipeta esterelizada. Os ascósporos em suspensão foram diluídos em 9,0 mL de solução salina e o volume de $0,1 \mathrm{~mL}$ semeado em placas de Petri contendo meio completo. A incubação foi feita por 72 horas. Após esse período, as colônias foram purificadas por estrias e inoculadas em placa mestra com 26 pontos (meio completo), onde foram transferidas com replicador multifio (Azevedo et. al., 1976) para os meios seletivos para testes com marcadores genéticos específicos. As placas mestras foram incubadas a $37^{\circ} \mathrm{C}$ e as leituras foram efetuadas com 24,48 e 72 horas, respectivamente.

Os dados obtidos pela análise do ciclo sexual permitem a organização dos marcadores nos grupos de ligação. Utilizou a fórmula abaixo e o teste de $\mathrm{X}^{2}$ para análise da segregação. 
$\mathrm{C}=\mathrm{R} \times 100 / \mathrm{t}$

onde:

$$
\begin{aligned}
& \mathrm{C}=\text { freqüência de recombinação } \\
& \mathrm{R}=\text { número de colônias recombinante } \\
& \mathrm{t}=\text { número total de colônias analisadas }
\end{aligned}
$$

3.2.5 Meios de Cultura e Soluções

3.2.5.1 Meio Mínimo (Pontecorvo et al., 1953)

$\begin{array}{ll}\mathrm{NaNO}_{3} & 6,0 \mathrm{~g} \\ \mathrm{KH}_{2} \mathrm{PO}_{4} & 1,5 \mathrm{~g} \\ \mathrm{KCl} & 0,5 \mathrm{~g} \\ \mathrm{MgSO}_{4} .7 \mathrm{H}_{2} \mathrm{O} & 0,5 \mathrm{~g} \\ \mathrm{FeSO}_{4} & 0,001 \mathrm{~g} \\ \mathrm{ZnSO}_{4} & 0,001 \mathrm{~g} \\ \mathrm{CuSO}_{4} & 0,001 \mathrm{~g} \\ \mathrm{Glicose} & 10,0 \mathrm{~g} \\ \text { Ágar } & 15,0 \mathrm{~g} \\ \text { Água destilada. } & 1000,0 \mathrm{~mL}\end{array}$

Após o preparo, o $\mathrm{pH}$ foi ajustado $6,8 \mathrm{com} \mathrm{NaOH} 1 \mathrm{~N}$, e autoclavado a 1 atm. por 20 minutos, sendo depois mantido à temperatura ambiente.

3.2.5.2 Meio Completo (Pontecorvo et al., 1953)

Aos componentes do meio mínimo (item 3.2.5.1) foram adicionados:

Peptona 2,0 $\mathrm{g}$

Caseína hidrolisada $\quad 1,5 \mathrm{~g}$

Extrato de levedura $\quad 2,0 \mathrm{~g}$

Solução de Vitaminas $\quad 1,0 \mathrm{~mL}$

Após o preparo, o $\mathrm{pH}$ foi ajustado $6,8 \mathrm{com} \mathrm{NaOH} 1 \mathrm{~N}$, e autoclavado a 1 atm. por 20 minutos, sendo depois mantido à temperatura ambiente. 
3.2.5.3 Meio Completo líquido (Pontecorvo et al., 1953)

Foi preparado seguindo o item 3.2.5.1, mas sem o acréscimo de ágar.

3.2.5.4 Meio Mínimo líquido (Pontecorvo et al., 1953)

Foi preparado seguindo o item 3.2.5.2, mas sem o acréscimo de ágar.

3.2.5.5 Meio Mínimo líquido acrescido de 4\% de Meio Completo

Adicionou ao meio mínimo líquido, $4 \%$ de meio completo líquido.

Distribuiu em tubos de ensaio com 2,5 mL dessa mistura. Após o preparo, o $\mathrm{pH}$ foi ajustado 6,8 com $\mathrm{NaOH} 1 \mathrm{~N}$, e autoclavado a 1 atm. por 20 minutos, sendo depois mantido à temperatura ambiente.

3.2.5.6 Solução de vitaminas

Ácido fólico

$50,0 \mathrm{mg}$

Ácido nicotínico

$100,0 \mathrm{mg}$

Ácido $\rho$-aminobenzóico

$50,0 \mathrm{mg}$

Ácido pantotênico

200,0 mg

Biotina

$2,0 \mathrm{mg}$

Cloreto de colina

200,0 mg

Meso-inositol

$400,00 \mathrm{mg}$

Piridoxina

$50,0 \mathrm{mg}$

Riboflavina

$100,0 \mathrm{mg}$

Tiamina

$50,0 \mathrm{mg}$

Água destilada

$100,0 \mathrm{~mL}$

A água destilada e o frasco escuro foram previamente autoclavados a 1 atm. por 20 minutos. Após o preparo, a solução foi mantida em banho-maria $\left(100^{\circ} \mathrm{C}\right)$ por 20 minutos. A solução foi mantida a $4^{\circ} \mathrm{C}$. 
3.2.5.7 Meio de Galactose (Roberts, 1959)

Foi preparado como o meio mínimo (3.2.5.1), mas substituiu a glicose por igual quantidade de galactose. Após o preparo, o $\mathrm{pH}$ foi ajustado $6,8 \mathrm{com} \mathrm{NaOH} 1 \mathrm{~N}$, e autoclavado a $1 \mathrm{~atm}$. por 20 minutos, sendo depois mantido à temperatura ambiente.

3.2.5.8 Meio de Acetato de Amônio (Apiron, 1962)

Acetato de Amônio

$12,0 \mathrm{~g}$

$\mathrm{NaCl}$

$2,0 \mathrm{~g}$

$\mathrm{MgSO}_{4} \cdot 7 \mathrm{H}_{2} \mathrm{O}$

$0,5 \mathrm{~g}$

$\mathrm{KH}_{2} \mathrm{PO}_{4}$

$3,0 \mathrm{~g}$

$\mathrm{FeSO}_{4}$.

$0,001 \mathrm{~g}$

$\mathrm{ZnSO}_{4}$

0,001

$\mathrm{CuSO}_{4}$

$0,001 \mathrm{~g}$

Ágar

$15,0 \mathrm{~g}$

Água destilada

1000,0 mL

Após o preparo, o $\mathrm{pH}$ foi ajustado $6,8 \mathrm{com} \mathrm{NaOH} 1 \mathrm{~N}$, e autoclavado a 1 atm. por 20 minutos, sendo depois mantido à temperatura ambiente.

\subsubsection{Solução de tween 80}

Tween 80

Água destilada

Após o preparo, a solução foi autoclavada a 1 atm. por 20 minutos, sendo

depois mantido à temperatura a $4^{\circ} \mathrm{C}$

\subsubsection{Solução Salina}

$\mathrm{NaCl}$

Água destilada

Após o preparo, a solução foi autoclavada a $1 \mathrm{~atm}$. por 20 minutos, sendo

depois mantido à temperatura a $4^{\circ} \mathrm{C}$ 
3.2.5.11 Solução de $\rho$ FA (Lhoas, 1961)

$\rho$ FA ( $\rho$-fluorfenilalanina)

$1,0 \mathrm{~g}$

Água destilada

$100,0 \mathrm{~mL}$

A solução foi mantida em banho-maria $\left(100^{\circ} \mathrm{C}\right)$ por 20 minutos. A solução foi mantida a $4^{\circ} \mathrm{C}$.

\subsubsection{Solução de suplementos adicionais para o meio mínimo}

As soluções estoque para cada um dos suplementos foram preparadas em água destilada e levadas ao banho-maria $\left(100^{\circ} \mathrm{C}\right)$ por 20 minutos. As soluções foram mantidas a $4^{\circ} \mathrm{C}$. Durante as análises genéticas foram adicionados os requisitos nutricionais ao meio mínimo.

Tabela 2. Requisitos nutricionais adicionados ao meio mínimo durante as análises genéticas

\begin{tabular}{ccc}
\hline Solução Estoque & $\mathrm{mg} / 100 \mathrm{~mL}$ de $\mathrm{H}_{2} \mathrm{O}$ & $\begin{array}{c}\text { Concentração final no meio de cultura } \\
(\mu \mathrm{g} / \mathrm{mL})\end{array}$ \\
\hline Adenina & 500,00 & 25,00 \\
Ácido Nicotínico & 10,00 & 0,50 \\
Ácido $\rho$-aminobenzóico & 5,00 & 0,25 \\
Biotina & 4,00 & 20,00 \\
Metionina & 1000,00 & 50,00 \\
Piridoxina & 5,00 & 0,25 \\
Prolina & 1000,00 & 50,00 \\
Riboflavina & 10,0 & 0,50 \\
Tiossulfato de Sódio & 2000,00 & 100,00 \\
\hline
\end{tabular}




\subsection{Análise Citológica}

3.3.1 Coloração de Núcleos e Parede Celular com Corante Fluorescente (Pascon et al., 2001)

Os conídios de cada linhagem analisadas foram inoculados em meio completo líquido e incubadas a $37^{\circ} \mathrm{C}$. As amostras foram retiradas em intervalos de tempo pré-determinados: $0,2,4,6,8,12$ e 16 horas. Nos intervalos de tempo 20 e 32 horas, os conídios de cada amostra foram inoculados em meio completo sólido sobre lamínulas e incubados a $37^{\circ} \mathrm{C}$.

Em uma segunda análise, os conídios de cada linhagem foram inoculados em meio completo líquido e incubados à temperatura de $28^{\circ} \mathrm{C}$ (permissiva) e $42^{\circ} \mathrm{C}$ (restritiva). As amostras foram retiradas em intervalos de tempo pré-determinados: 4, $8 \mathrm{e}$ 12 horas. No intervalo de 24 horas, os conídios de cada amostra foram inoculados em meio completo sólido sobre lamínulas e incubados à temperatura de $28^{\circ} \mathrm{C}$ (permissiva) e $42^{\circ} \mathrm{C}$ (restritiva).

Foi retirada uma alíquota $(1 \mathrm{~mL})$ de cada meio em diferentes intervalos de tempo e fixados em lâmina com solução de albumina $(1 \mathrm{~mL})$ mais solução de fixação (1 $\mathrm{mL}$ ) por 30 minutos, após foram lavadas rapidamente com água destilada, o mesmo foi realizado com as lamínulas. A coloração fluorescente foi realizada utilizando $0,2 \mu \mathrm{g} / \mathrm{mL}$ de Calcofluor ("fluorescent brightener 28 - Sigma") e 0,1 $\mu \mathrm{g} / \mathrm{mL}$ 4', 6-diamidino-2phenylindole (DAPI - Sigma), por 15 minutos. As lâminas e lamínulas foram lavadas rapidamente em água destilada, e montadas com Vectashield (Vector). As preparações foram examinadas em luz ultravioleta, utilizando microscópio de fluorescência Axio plan 2 - Zeiss. 
3.3.2 Soluções para Análise Citológica

3.3.2.1 Solução de Fixação

Formaldeído

$4,0 \mathrm{~mL}$

$\mathrm{K}_{2} \mathrm{PO}_{4} \mathrm{pH} 7,050 \mathrm{mM}$

$94,0 \mathrm{~mL}$

Tween

$2,0 \mathrm{~mL}$

A solução foi preparada e mantida a $4^{\circ} \mathrm{C}$.

3.3.2.2 Solução de Albumina 20\%

Foi preparada uma solução com $20 \mathrm{~mL}$ de clara de ovo em $80 \mathrm{~mL}$ de água destilada. A solução foi filtrada e conservada em frasco escuro a $-20^{\circ} \mathrm{C}$.

3.3.2.3 Solução estoque de DAPI (4,6-diamino-2-phenylindol - Sigma)

DAPI

$0,01 \mathrm{~g}$

Água destilada

$10,0 \mathrm{~mL}$

A solução foi mantida em frasco escuro à $4^{\circ} \mathrm{C}$.

3.3.2.4 Solução estoque de calcofluor ("fluorescent brightener 28 - Sigma")

Calcofluor

$0,02 \mathrm{~g}$

Água destilada $20,0 \mathrm{~mL}$

O Calcofluor foi dissolvido em uma gota de $\mathrm{KOH} 1 \mathrm{~N}$, e seu volume foi completado para $20,0 \mathrm{~mL}$ com água destilada. A solução foi mantida em frasco escuro à $4^{\circ} \mathrm{C}$.

\subsubsection{Coloração de Núcleo com Giemsa-HCl (Robinow \& Caten, 1969)}

Esta técnica foi utilizada para contagem dos núcleos no variante deteriorado V5 e das linhagens padrões MSE, PPY, A. As linhagens foram crescidas sobre lamínula em meio completo por 5 dias a temperatura de $28^{\circ} \mathrm{C}, 37^{\circ} \mathrm{C}$ e $42^{\circ} \mathrm{C}$. Após este período procedeu a coloração de Giemsa, com a fixação durante 15 minutos. Em seguida, as lamínulas passaram por uma série alcoólica (etanol 90\%, 70\% e 50\%) com 5 minutos. Foi realizada a hidrolise com $\mathrm{HCl} 1 \mathrm{~N}$ por 15 minutos a $63^{\circ} \mathrm{C}$ em banho-maria. 
As lamínulas foram lavadas em água destilada, por 3 vezes durante 10 minutos. A tamponagem do sistema foi realizada com tampão fosfato $0,2 \mathrm{M} \mathrm{pH} \mathrm{7,0} \mathrm{durante} 1$ hora. A coloração foi feita, adicionando-se 2,0 mL de Giemsa a 10,0 mL de tampão fosfato 0,2 M pH 7,0 durante 15 minutos. Após a coloração, as lamínulas foram lavadas em

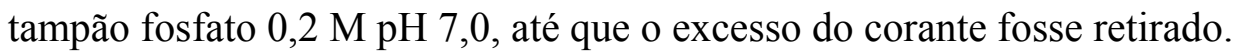

\subsubsection{Tampão Fosfato 0,2 M pH 7,0}

Solução A

$\mathrm{NaH}_{2} \mathrm{PO}_{4}$

$24,0 \mathrm{~g}$

Água destilada

$1000,0 \mathrm{~mL}$

Solução B

$\mathrm{Na}_{2} \mathrm{HPO}_{4} \cdot \mathrm{H}_{2} \mathrm{O}$

$71,6 \mathrm{~g}$

Água destilada

$1000,0 \mathrm{~mL}$

Misturou a solução A com a solução B, até obter o pH 7,0. Conservou solução A e B sob refrigeração a $4^{\circ} \mathrm{C}$. O tampão fosfato é preparado no momento do uso.

\subsubsection{Solução de $\mathrm{KCl}$ 0,6 M pH 7,0}

Colocou 44,7 g de $\mathrm{KCl}$ em cerca de $350 \mathrm{~mL}$ de solução A. Aqueceu até dissolver o $\mathrm{KCl}$, adicionou, então, a solução B até pH 7,0. Acertou o volume próximo a 1000,o mL com o tampão fosfato $0,2 \mathrm{M} \mathrm{pH} \mathrm{7,0.} \mathrm{Ajustou} \mathrm{o} \mathrm{pH}$ final para 7,0 com solução A ou B conforme o caso, até o volume final de 1000,0 mL. A solução foi autoclavada em 1 atm por 20 minutos e conservada em refrigerador a $4^{\circ} \mathrm{C}$.

\subsubsection{Solução de fixação}

Etanol

Ácido acético glacial

Ácido lático
$6,0 \mathrm{~mL}$

$1,0 \mathrm{~mL}$

$1,0 \mathrm{~mL}$

A solução de fixação foi preparada no momento de uso dentro de capela de exaustão. 
3.3.3.4 Solução de $\mathrm{HCl} 1 \mathrm{~N}$

$\mathrm{HCl}$ concentrado

$82,5 \mathrm{~mL}$

Água destilada

1000,0 mL

A solução foi mantida em frasco escuro à temperatura ambiente.

\subsubsection{Solução Estoque Giemsa}

Giemsa em pó

$1,0 \mathrm{~g}$

Glicerina

$66,0 \mathrm{~mL}$

Metanol

$66,0 \mathrm{~mL}$

Misturou o Giemsa com glicerina a $60^{\circ} \mathrm{C}$. Após resfriamento, adicionou o metanol, filtrou a solução e armazenou a temperatura ambiente em frasco escuro.

\subsubsection{Solução Corante}

Tampão fosfato 0,2 M pH 7,0

10,0 mL

Solução de Giemsa

$2,0 \mathrm{~mL}$

Preparar a solução corante apenas no momento do uso.

\subsection{Isolamento de mutantes para nitrato redutase (niaD)}

3.4.1 Metodologia para isolamento de mutantes de A. nidulans resistentes a Clorato de Potássio 0,3 M

Foi utilizada suspensão de conídios da linhagem A de A. nidulans (duplicação cromossômica $\mathrm{I} \rightarrow \mathrm{II}$ ). Foram inoculado $10^{5}$ conídios por $\mathrm{mL}$ de solução Tween, em Meio Mínimo com Glutamato de potássio e mais clorato de potássio 0,3 M. Deste modo foram isolado mutantes espontâneos resistentes ao clorato de potássio.

Após a seleção dos mutantes foram realizados diversos testes em diferentes meio de cultura para selecionar apenas os mutantes niaD. 
3.4.2 Meio de Cultura e Soluções

3.4.2.1 Meio Mínimo sem fonte de Nitrogênio (Cove, 1976a, b)

Solução de sais

Glicose

Água destilada
$20 \mathrm{~mL}$

$10 \mathrm{~g}$

$1000,0 \mathrm{~mL}$

Após o preparo, o pH foi ajustado 6,8 com $\mathrm{NaOH} 1 \mathrm{~N}$, e autoclavado a 1 atm. por 20 minutos, sendo depois mantido à temperatura ambiente.

3.4.2.2 Solução de Sais (Cove, 1976 a, b)

$\begin{array}{ll}\mathrm{KCl} & 26,0 \mathrm{~g} \\ \mathrm{MgSO}_{4} \times 7 \mathrm{H}_{2} \mathrm{O} & 26,0 \mathrm{~g} \\ \mathrm{KH}_{2} \mathrm{PO}_{4} & 76,0 \mathrm{~g} \\ \text { Elementos traços } & 20 \mathrm{~mL} \\ \text { Água destilada } & 1000,0 \mathrm{~mL}\end{array}$

Após o preparo a solução foi mantida a $4^{\circ} \mathrm{C}$.

3.4.2.3 Solução traços (Cove, $1976 \mathrm{a}, \mathrm{b}$ )

$\begin{array}{ll}\mathrm{NaB}_{4} \mathrm{O}_{7} \times 10 \mathrm{H}_{2} \mathrm{O} & 40,0 \mathrm{mg} \\ \mathrm{CuSO}_{4} \times 5 \mathrm{H}_{2} \mathrm{O} & 400,0 \mathrm{mg} \\ \mathrm{FeSO}_{4} \times 2 \mathrm{H}_{2} \mathrm{O} & 800,0 \mathrm{mg} \\ \mathrm{MnSO}_{4} \times 2 \mathrm{H}_{2} \mathrm{O} & 800,0 \mathrm{mg} \\ \mathrm{NaMoO}_{4} \times 2 \mathrm{H}_{2} \mathrm{O} & 800,0 \mathrm{mg} \\ \mathrm{ZnSO}_{4} \times 2 \mathrm{H}_{2} \mathrm{O} & 800,0 \mathrm{mg}\end{array}$

Após o preparo a solução foi mantida a $4^{\circ} \mathrm{C}$.

3.4.2.4 Meio de Cultura para isolamento de mutantes para nitrato redutase

Foi preparado seguindo o item 3.4.2.1, e foi adicionado $10 \mathrm{mM}$ de glutamato de potássio (fonte de nitrogênio) mas 0,3 $\mathrm{M}$ de Clorato de Potássio. 
3.4.2.5 Meios de cultura com diferentes fontes de nitrogênio

Os Meios de Cultura foram preparados como descrito no item 3.4.2.1, sendo que para as análises dos mutantes isolados cada fonte de nitrogênio diferente foi adicionada ao meio de cultura na hora do uso (Tabela 3 ).

Tabela 3. Quantidade de fontes de nitrogênio adicionada ao meio mínimo de cultura Fonte de Nitrogênio Quantidade adicionada em Concentração final no meio $10 \mathrm{~mL}$ de água destilada de cultura $(\mathrm{mM})$

\begin{tabular}{ccc}
\hline Nitrato de sódio 0,07 M & 5,95 & 70,0 \\
Nitrito de sódio 0,01 M & 0,69 & 10,0 \\
Tartarato de amônio 0,01 M & 1,84 & 10,0 \\
Cloreto de amônio 0,01 M & 0,53 & 10,0 \\
Uréia 0,005 M & 0,03 & 5,0 \\
Hipoxantina 0,0007 M & 0,27 & 0,7 \\
\hline
\end{tabular}

As fontes de nitrogênio foram preparadas e cada uma delas mantidas em frascos contendo $10 \mathrm{~mL}$ de água destilada. Após o preparo as soluções foram autoclavada por 20 minutos a $1 \mathrm{~atm}$. e mantidas a $4^{\circ} \mathrm{C}$. Posteriormente $1 \mathrm{~mL}$ de cada solução foi adicionada, separadamente em $100 \mathrm{~mL}$ de meio mínimo sem fonte de nitrogênio.

3.4.3 Isolamento de mutantes para nitrato redutase (niaD) por meio do ciclo sexual de $A$. nidulans

A metodologia utilizada foi à mesma do item 3.4.1., mas foi realizado antes o cruzamento via ciclo sexual, com formação de cleistotécios (ciclo meiótico) entre as linhagens MSE e A de A. nidulans.

Foram selecionados alguns cleistotécios, que foram rompidos em solução tween e diluídos. A suspensão de ascósporos foi semeadas em meio de cultura mínimo contento Nitrito de sódio 0,01 M e Clorato de Potássio 0,45 M. Posteriormente foram feitos testes com meio de cultura mínimos contendo Amônia e Hipoxantina, para 
selecionar apenas mutantes niaD. Este isolamento foi realizado para que os mutantes obtidos não apresentassem as marcas prolina e ácido para-aminobenzóicodo (paba), como ocorrido no primeiro isolamento (item 3.4.1).

3.4.3.1 Meio Mínimo com $10 \mathrm{mM}$ de Nitrito de sódio mais 0,45 M de Clorato de Potássio

O Meio de Cultura foi preparado como descrito no item 3.4.2.1, sendo acrescentado $10 \mathrm{mM}$ de nitrito de potássio mais 0,45 M de Clorato de Potássio.

3.4.3.2 Meio Mínimo com $10 \mathrm{mM}$ de Tartarato e amônia mais $0,45 \mathrm{M}$ de Clorato de Potássio

O Meio de Cultura foi preparado como descrito no item 3.4.2.1, sendo acrescentado $10 \mathrm{mM}$ de Tartarato e amônia mais 0,45 $\mathrm{M}$ de Clorato de Potássio.

3.4.3.3 Meio Mínimo com $10 \mathrm{mM}$ de Cloreto de amônia de sódio mais 0,45 $\mathrm{M}$ de Clorato de Potássio

O Meio de Cultura foi preparado como descrito no item 3.4.2.1, sendo acrescentado $10 \mathrm{mM}$ de Cloreto de amônia mais 0,45 M de Clorato de Potássio.

3.4.3.4 Meio Mínimo com 0,7 mM de Hipoxantina mais 0,45 M de Clorato de Potássio

O Meio de Cultura foi preparado como descrito no item 3.4.2.1, sendo acrescentado 0,7 $\mathrm{mM}$ de hipoxantina mais 0,45 $\mathrm{M}$ de Clorato de Potássio.

\subsubsection{Teste de Reversão}

$\mathrm{O}$ teste de reversão foi utilizado para os mutantes niaD obtidos espontaneamente, nos item 3.4.1 e 3.4.3 Este teste verificou a taxa de reversibilidade espontânea destes mutantes, sendo que os mutantes que apresentarem alta freqüência de reversão serão os prováveis candidatos para estudos moleculares. Para o teste foi utilizado a formula: 


\author{
$\mathrm{n}^{\mathrm{o}}$ de colônias crescidas em MM (nitrato) \\ $\mathrm{FR}^{*}=$ \\ $\mathrm{n}^{\mathrm{o}}$ de colônias crescidas em $\mathrm{MM}$ com nitrito mais $0,45 \mathrm{M}$ de $\mathrm{KClO}_{4} \mathrm{x}$ \\ diluição utilizada
}

\title{
3.5 Análises Moleculares
}

3.5.1 Extração de DNA de fungos filamentosos (Raeder \& Broda, 1985)

Para a extração do DNA micelial as linhagens padrões (MSE e A) foram crescidas em meio completo líquido, a linhagem G125 e os mutantes niaD obtidos foram crescidos em meio mínimo com nitrito, pelo período de 30 horas, sob agitação (150 rpm) à $37^{\circ} \mathrm{C}$. Após este período, o micélio foi filtrado em filtro Büchner e lavado em água destilada esterilizada.

O micélio foi triturado em nitrogênio líquido e distribuído em tubos para microcentrífuga de 2,0 mL. Adicionou 1,0 mL de solução de extração de DNA total de fungos filamentosos, e agitou suavemente por inversão. Esta mistura foi incubada por 1 hora a $65^{\circ} \mathrm{C}$. Após o período de incubação, adicionou-se um volume de fenol (aproximadamente 1,0 mL), misturou as fases e centrifugou-se a $12000 \mathrm{rpm}$ por 10 minutos em microcentrífuga. Desprezou a fase fenólica, e transferiu a fase aquosa para um novo tubo, e acrescentou um volume de clorofane (aproximadamente 1,0 mL). Misturou as fases e centrifugou-se como anteriormente. Desprezou a fase fenólica, e transferiu a fase aquosa para um novo tubo adicionando à fase aquosa um volume de clorofil (aproximadamente 1,0 mL). Misturou as fases e centrifugou. Após a centrifugação, retirou a fase aquosa e adicionou $\mathrm{NaCl} 3 \mathrm{M}$ para uma concentração final de $0,3 \mathrm{M}$. Adicionou dois volumes de etanol absoluto, resfriado a $-20^{\circ} \mathrm{C}$. Misturou vagarosamente até visualizar o DNA precipitado. Os tubos de microcentrífuga contendo o DNA precipitado foram submetidos à centrifugação a $12000 \mathrm{rpm}$ por 15 minutos. O sobrenadante foi desprezado e o pellet formado foi lavado rapidamente com etanol $70 \%$. O etanol foi descartado, sendo o DNA seco a temperatura ambiente. O DNA precipitado foi ressuspendido em tampão TE (aproximadamente $100 \mu \mathrm{L}$ ). 
Os DNAs extraídos foram quantificados e sua integridade verificada em gel de agarose $0,8 \%$. A quantificação foi realizada com o auxílio de diferentes concentrações de DNA do fago lambda de origem comercial.

\subsubsection{Soluções}

3.5.2.1 Tampão de extração de DNA

Tris-HCl $1 \mathrm{M} \mathrm{pH} \mathrm{8,0} \quad 40 \mathrm{~mL}$

$\mathrm{NaCl} 5 \mathrm{M} \quad 10 \mathrm{~mL}$

EDTA $0,5 \mathrm{M} \mathrm{pH} \mathrm{8,0} 10 \mathrm{~mL}$

SDS $10 \% \quad 20 \mathrm{~mL}$

$\mathrm{H}_{2} \mathrm{O}$ destilada esterilizada $\quad 120 \mathrm{~mL}$

A solução foi preparada no momento do uso.

\subsubsection{Tris- $\mathrm{HCl} 1 \mathrm{M} \mathrm{pH} \mathrm{8,0}$}

Trizma base

$121,1 \mathrm{~g}$

$\mathrm{H}_{2} \mathrm{O}$ destilada $1000 \mathrm{~mL}$

$\mathrm{O}$ pH foi ajustado para 8,0 com $\mathrm{HCl}$ concentrado. A solução foi autoclavada e mantida à $4^{\circ} \mathrm{C}$.

3.5.2.3 Solução de $\mathrm{NaCl} 5 \mathrm{M}$

$\mathrm{NaCl}$ $29,22 \mathrm{~g}$

$\mathrm{H}_{2} \mathrm{O}$ destilada $100 \mathrm{~mL}$

A solução foi autoclavada e mantida à $4^{\circ} \mathrm{C}$.

\subsubsection{4 Ácido Etileno - Diamino - Tetracético (EDTA) 0,5 M pH 8,0}

EDTA

$\mathrm{H}_{2} \mathrm{O}$ Milli-Q

$200 \mathrm{~mL}$

$\mathrm{O}$ pH foi ajustado para 8,0 com pastilhas de $\mathrm{NaOH}$. A solução foi autoclavada e mantida à $4^{\circ} \mathrm{C}$. Para o preparo da solução EDTA $50 \mathrm{mM}$, foram feitas diluições apropriadas a partir do estoque EDTA 0,5M. 
3.5.2.5 Dodecil Sulfato de Sódio (SDS) 10\% (p/v)

SDS

$20 \mathrm{~g}$

$\mathrm{H}_{2} \mathrm{O}$ destilada

$200 \mathrm{~mL}$

A solução foi autoclavada e mantida a temperatura ambiente.

\subsubsection{Soluções $\mathrm{NaCl} 3 \mathrm{M}$}

$\mathrm{NaCl}$

$\mathrm{H}_{2} \mathrm{O}$

$100 \mathrm{~mL}$

A solução foi autoclavada e mantida à $4^{\circ} \mathrm{C}$.

\subsubsection{Fenol (Sambrook et al., 1989)}

$\mathrm{O}$ fenol cristalizado (Synth) foi dissolvido em banho-maria a $65^{\circ} \mathrm{C}$ e adicionado um volume de tampão Tris- $\mathrm{HCl}$ 0,5 M pH 8,0. A solução foi submetida a agitação em um agitador magnético por 30 minutos a fim de equilibrar o $\mathrm{pH}$. A fase aquosa foi retirada e o procedimento repetido com Tris- $\mathrm{HCl} 0,1 \mathrm{M} \mathrm{pH} \mathrm{8,0} \mathrm{até} \mathrm{o} \mathrm{pH} \mathrm{da}$ fase fenólica atingir 8,0 (medido com papel de filtro). Em seguida, removeu-se a fase aquosa e adicionaram-se 0,1 volume de Tris- $\mathrm{HCl} 0,1 \mathrm{M} \mathrm{pH} \mathrm{8,0.} \mathrm{O} \mathrm{fenol} \mathrm{foi} \mathrm{estocado} \mathrm{em}$ frasco escuro a $4^{\circ} \mathrm{C}$.

3.5.2.8 Clorofane (Sambrook et al., 1989)

Para o preparo do clorofane misturou-se um volume de fenol com um volume de clorofórmio. O clorofane foi estocado em frasco escuro a $4^{\circ} \mathrm{C}$.

3.5.2.9 Clorofil (Sambrook et al., 1989)

Foram misturados clorofórmio e álcool isoamílico na proporção de 24:1 $(\mathrm{v} / \mathrm{v})$. O clorofil foi estocado em frasco escuro a $4^{\circ} \mathrm{C}$.

\subsubsection{Tampão Tris-EDTA (TE)}

Tris- $\mathrm{HCl} 1 \mathrm{M}$ pH 8,0

$1 \mathrm{~mL}$

EDTA 0,5 M pH 8,0

$0,2 \mathrm{~mL}$ 
Completou-se o volume para $100 \mathrm{~mL}$ com $\mathrm{H}_{2} \mathrm{O}$ destilada. A solução foi autoclavada e mantida à $4^{\circ} \mathrm{C}$.

\subsubsection{Purificação do DNA}

Os DNAs extraídos como descrito no item 3.5.2. foram submetidos a tratamento com RNAse, a um concentração de $50 \mu \mathrm{g}$ de enzima $/ \mathrm{mL}$ por 1 hora a $37^{\circ} \mathrm{C}$. Por fim, os DNAs foram quantificados e sua integridade verificada em gel de agarose 0,8\%. A quantificação foi realizada com o auxílio de diferentes concentrações de DNA do fago-lambda de origem comercial.

\subsubsection{RNAse}

$\begin{array}{ll}\text { RNAse (pancreática) } & 0,01 \mathrm{~g} \\ \text { Tris- } \mathrm{HCl} 0,2 \mathrm{M} \mathrm{pH} \mathrm{8,0} & 0,5 \mathrm{~mL} \\ \mathrm{NaCl} 0,3 \mathrm{M} & 0,05 \mathrm{~mL} \\ \text { Água destilada esterilizada } & 0,45 \mathrm{~mL}\end{array}$

A solução foi aquecida a $100^{\circ} \mathrm{C}$ por 15 minutos e depois de esfriada foi distribuída em alíquotas e estocada a $-20^{\circ} \mathrm{C}$.

3.5.4 Construção dos Primers (Gass \& Donaldson, 1995; Frey et al., 1998)

\subsubsection{Construção dos Primers para o gene niaD}

Os primers para a amplificação do gene niaD (para localização do segmento de inserção) foram construídos utilizando os programa Generunner e Jellyfish, a partir da seqüência M58291.6 do GeneBank - NCBI HomePage (http://www.ncbi.nlm.nih.gov/) (Tabela 4).

3.5.4.2 Construção dos Primers para amplificação do gene bristle

Os primers para a amplificação do gene bristle, foram desenhados por Rocha (1997) (Tabela 4). 


\subsubsection{Construção dos Primers para transposase}

Os primers Fot1.1F e Fot 1.1R, para a amplificação do gene da transposase (para localização do elemento de transposição) foram construídos utilizando o programa de alinhamento de seqüências ClustalW (http://www.ebi.ac.uk/clustalw), a partir das seqüências das transposases dos fungos filamentosos Fusarium oxysporum (Elemento Fot1 - X64799.1), Fusarium solani (Elemento Fot1- AF443562.1), Nectria haematococca (Elemento Nht1 - AF443563.1) e Neocosmospora sp. (Elemento Fot1AF434909.1). Todas as seqüências analisadas estão depositadas no GeneBank - NCBI HomePage (http://www.ncbi.nlm.nih.gov/).

Os primers Fot1 F e Fot1 R, foram construídos por Migheli et al. (1999), sendo seqüências específicas para a amplificação do gene da transposase da família dos Elementos de Transposição Pogo.

Os primers ns5 F e ns3 R, foram construídos por Hua-Van et al. (2001), sendo seqüências específicas para a amplificação do gene da transposase da família dos Elementos de Transposição Ant1 e Tc1, precisamente o elemento Impala (Tabela 4).

\subsubsection{Construção dos Primers para transcriptase reversa}

O primer Gyp F - Gyp R, para a amplificação do gene da transcriptase reversa (para localização do elemento de transposição) foram construídos utilizando o programa de alinhamento de seqüências ClustalW (http://www.ebi.ac.uk/clustalw), a partir das seqüências das transcriptase reversa dos fungos filamentosos Fusarium oxysporum (Elemento Forest - AF076627) e Magnaporthe grisea (Elemento MAGGY L35053). Todas as seqüências analisadas estão depositadas no GeneBank - NCBI HomePage (http://www.ncbi.nlm.nih.gov/) (Tabela 4).

3.5.4.5. Construção dos primers para amplificação do transposons de Aspergillus nidulans MATE

Os primers mateF e mateR, para a amplificação do transposon MATE de A. nidulans (para localização do elemento de transposição) foram construídos utilizando o programa de alinhamento de seqüências ClustalW (http://www.ebi.ac.uk/clustalw), a 
partir das seqüências dos transposons MATE 1b (BK001594) MATE 4 (BK001595) e MATE 9 (BK001592). Todas as seqüências analisadas estão depositadas no GeneBank NCBI HomePage (http://www.ncbi.nlm.nih.gov/). As seqüências analisadas podem, também, ser nos encontradas site http://wwwgenome.wi.mit.edu/annotation/fungi/aspergillus/, dentro de contigs :MATE 1b (conitg 1.122), MATE 4 (contig 1.45) e MATE 9 (contig 1.18) (tabela 4).

Tabela 4. Primers utilizados

\begin{tabular}{|c|c|c|}
\hline Primer & Região Alvo & Seqüências \\
\hline NiaD2 & Gene niaD & F - ATACCCAAGACTCTCAAGACTTCCCAGATCAG \\
\hline NiaD2 & Gene niaD & R - CATCTGTCTCCTCCGACACGCACA \\
\hline NiaD4 & Gene niaD & R - TACTGGTCTGTCCTTGGTATGATGAACAAC \\
\hline NiaDCDS & Gene niaD & F - ACAATGTCTACAACCGTCACACAAGTGC \\
\hline NiaDCDS & Gene niaD & R - CCTTCATTACTTCTAGACGGGTTCGCAT \\
\hline \multirow[t]{2}{*}{$\mathrm{Brl}$} & Gene bristle & F - GGTCGGAGATGAAGAAATG \\
\hline & & R - AGGAATGAAAGAGGGCTAAT \\
\hline \multirow[t]{2}{*}{ ns5F-ns3R } & Transposon & F - CGATGCCTCGAGGCAAGGAA \\
\hline & Ant1 e Tc1 (impala) & R - TCTCTGCCTTCATCAACGCCC \\
\hline \multirow[t]{2}{*}{ Fot 1} & Transposon Pogo & F - AGTCAAGCACCCATGTAACCGACCCCCCC \\
\hline & & R - GGGGGGGTCGGTTACATGGGTGCTTGACT \\
\hline \multirow[t]{2}{*}{ Fot1.1 } & Transposon Pogo & F - TAAATGCTGCGACCCCGGCGAA \\
\hline & & R - AGAAG(A/G)TATTCCTTCCC(T/C)AAA \\
\hline \multirow[t]{2}{*}{ Gyp } & Retrotransposon & F - TGAAACAGATTG(C/A)(C/T)G \\
\hline & Gypsy & R - GGAAGG(A/G)TCGGTCTC(G/C)AG \\
\hline \multirow[t]{2}{*}{ Mate } & Transposon & F - GAGCTAACTCTAAGTCG(A/G)C \\
\hline & MATE & R - GACTAGTCAGT(A/G)ACTAG \\
\hline
\end{tabular}




\subsubsection{Condições para amplificação}

A reação base para amplificação dos PCRs, dos primers utilizados deste trabalho estão na Tabela 5.

Tabela 5. Reação de PCR utilizada

\begin{tabular}{|c|c|c|}
\hline Soluções & 1 reação $(\mu \mathrm{L})$ & Concentração final por reação \\
\hline Tampão10 x & 2,5 & $1 \mathrm{x}$ \\
\hline DNTPs $-2,5 \mathrm{mM}$ & 2,0 & $0,25 \mathrm{mM}$ \\
\hline $\mathrm{MgCl}_{2}-50 \mathrm{mM}$ & 1,5 & $3,4 \mathrm{mM}$ \\
\hline Primer $1-100 \mathrm{mM}$ & 0,1 & $30 \mathrm{mM}$ \\
\hline Primer $2-100 \mathrm{mM}$ & 0,1 & $30 \mathrm{mM}$ \\
\hline TAQ polimerase (Invitrogen) $-5 \mathrm{u} / \mu \mathrm{L}$ & 0,3 & $1,5 \mathrm{u}$ \\
\hline Templete 10 - $15 \eta g$ & 5,0 & $2,5 \eta \mathrm{g}$ \\
\hline $\mathrm{H}_{2} \mathrm{O}$ destilada & 18,5 & $18,5 \mu \mathrm{L}$ \\
\hline Total & 30,0 & $30 \mu \mathrm{L}$ \\
\hline
\end{tabular}

As reações controle foram realizadas com a adição de todos os componentes da reação, exceto o DNA genômico (substituído por água Milli-Q esterilizada). A amplificação foi realizada no termociclador (Perkin-Elmer - Gene Amp PCR System 9700).O programa utilizados para os primers do gene niaD foi:

Ciclo 1 - desnaturação inicial de $94^{\circ} \mathrm{C}$ por 5 minutos;

Ciclo 2 - desnaturação $94^{\circ} \mathrm{C}$ por 30 segundos;

Ciclo 3 - anelamento $64^{\circ} \mathrm{C}$ por 30 segundos;

Ciclo 4 - extensão $72^{\circ} \mathrm{C}$ por 4 minutos;

Ciclo 5 - repetição dos ciclos 2 - 4 por 35 ciclos;

Ciclo $6-72^{\circ} \mathrm{C}$ por 7 minutos.

Para os primers da transposase e transcriptase reversa, foram utilizados como controle de amplificação todos os componentes da reação, exceto o DNA 
genômico (substituído por água Milli-Q esterlizada), foi utilizado como controle positivo o DNA genômico do fungo filamentoso Fusarium oxysporum, que apresenta os Elementos de Transposição.

O programa utilizado para os primers da transposase e transcriptase reversa foi, primeiramente um gradiente de temperatura, realizado no termociclador DNA Engine - Gradient Cycle - PTC - 200 - Peltier thermal Cycler.

Ciclo 1 - desnaturação inicial de $94^{\circ} \mathrm{C}$ por 5 minutos;

Ciclo 2 - desnaturação $94^{\circ} \mathrm{C}$ por 30 segundos;

Ciclo 3 - anelamento $52^{\circ} \mathrm{C}-62^{\circ} \mathrm{C}$ (gradiente de temperatura) por 30 segundos;

Ciclo 4 - extensão $72^{\circ} \mathrm{C}$ por 2 minutos;

Ciclo 5 - repetição dos ciclo 2 - 4 por 35 ciclos;

Ciclo $6-72^{\circ} \mathrm{C}$ por 7 minutos.

As temperaturas testadas pelo gradiente foram: $52^{\circ} \mathrm{C} ; 52,8^{\circ} \mathrm{C} ; 54,8,{ }^{\circ} \mathrm{C}$; $56,3^{\circ} \mathrm{C} ; 58,0^{\circ} \mathrm{C} ; 60,0^{\circ} \mathrm{C} ; 62,0^{\circ} \mathrm{C}$.

O programa utilizado, após o teste de gradiente de temperatura foi:

O programa utilizado para os primers foi:

Ciclo 1 - desnaturação inicial de $94^{\circ} \mathrm{C}$ por 5 minutos;

Ciclo 2 - desnaturação $94^{\circ} \mathrm{C}$ por 30 segundos;

Ciclo 3 - anelamento $58^{\circ} \mathrm{C}$ por 30 segundos;

Ciclo 4 - extensão $72^{\circ} \mathrm{C}$ por 2 minutos;

Ciclo 5 - repetição dos ciclos 2 - 4 por 35 ciclos;

Ciclo $6-72^{\circ} \mathrm{C}$ por 7 minutos.

Para os primers do transposon MATE de A. nidulans foi utilizado como controle de amplificação todos os componentes da reação, exceto o DNA genômico (substituído por água Milli-Q esterilizada). 
Inicialmente foi realizado um teste de gradiente de temperatura (igual para os primers da transposase e transcriptase reversa) no DNA Engine - Gradient Cycle - PTC - 200 - Peltier thermal Cycler.

Após determinar a temperatura o programa utilizado foi de:

Ciclo 1 - desnaturação inicial de $94^{\circ} \mathrm{C}$ por 5 minutos;

Ciclo 2 - desnaturação $94^{\circ} \mathrm{C}$ por 30 segundos;

Ciclo 3 - anelamento $52^{\circ} \mathrm{C}$ por 30 segundos;

Ciclo 4 - extensão $72^{\circ} \mathrm{C}$ por 1,3 minutos;

Ciclo 5 - repetição dos ciclos 2 - 4 por 35 ciclos;

Ciclo $6-72^{\circ} \mathrm{C}$ por 7 minutos.

As amostras, após amplificação, foram misturadas com aproximadamente $5 \mu \mathrm{L}$ do tampão de corrida (6x) e separados por eletroforese, a $3 \mathrm{~V} / \mathrm{cm}$, em gel de agarose a $1 \%$. Após a eletroforese, o gel de agarose foi corado com brometo de etídio e visualizado sobre um transluminador de luz ultravioleta e fotodocumentado.

3.5.5.1 Tampão de corrida para eletroforese (6x concentrado) (Sambrook et al., 1989)

Azul de bromofenol

$250,0 \mathrm{mg}$

Xileno cianol FF $250,0 \mathrm{mg}$

Ficoll $15,0 \mathrm{~g}$

Água destilada $100,0 \mathrm{~mL}$

Após o preparo, o tampão foi dividido em alíquotas de 1,0 mL e estocado a $4^{\circ} \mathrm{C}$.

3.5.5.2 Tampão TAE (Sambrook et al., 1989)

Tris-base

Ácido acético glacial

NaEDTA
$242,0 \mathrm{~g}$

$57,1 \mathrm{~mL}$

$50 \mathrm{mM}$

O volume foi completado para $1000,0 \mathrm{~mL}$ com água destilada. No momento do uso o TAE foi diluído para 1 x com água destilada. 
3.5.5.3 Solução de Brometo de Etídio (Sambrook et al., 1989)

Brometo de Etídio

$1,0 \mathrm{~g}$

Água destilada

$100,0 \mathrm{~mL}$

A solução foi agitada durante 1 hora e estocado a temperatura ambiente em um frasco âmbar. Na hora do uso, $3 \mu \mathrm{L}$ da solução estoque foram adicionados a 100,0 mL de água destilada.

3.5.6 Purificação do produto de amplificação para sequenciamento

A purificação dos produtos de amplificação dos PCRs, foram realizadas com o kit comercial GFX ${ }^{\mathrm{TM}} \mathrm{PCR}$ - DNA and Gel Band Purification Kit - Amersham Biosciesnces, seguindo as recomendações do fabricante.

\subsubsection{Sequenciamento dos produtos de amplificação}

Após a purificação dos produtos de amplificação, foram realizadas as quantificações dos DNAs com fago $\lambda$ integro em gel de agarose $0,8 \%$. A quantificação seguiu as normas do Kit ABI Prism BigDye Terminator Cycle Sequencing Ready Reaction Kits - Original and verson 2.0 - Applied Biosystems. Após a quantificação uma nova reação de PCR para o sequenciamento foi preparada (Tabela 6).

Tabela 6. Reação de PCR para sequenciamento

\begin{tabular}{lc}
\multicolumn{1}{c}{ Soluções } & 1 reação $(\mu \mathrm{L})$ \\
\hline BigDye & 2,0 \\
Tampão - Save money & 2,0 \\
Primer $5 \rho \mathrm{M}$ & 2,0 \\
$\mathrm{X} \mu \mathrm{L}$ de DNA $(0,5-4,0 \eta \mathrm{g})$ & - \\
$\mathrm{X} \mu \mathrm{L}$ de água milli-Q & - \\
\hline Total & 10,0 \\
\hline
\end{tabular}


O programa para o sequenciamento foi realizado no termociclador Perkin-Elmer - (Gene Amp PCR System 9700).

Programa:

Ciclo $1-95^{\circ} \mathrm{C}$ por 20 segundos;

Ciclo $2-50^{\circ} \mathrm{C}$ por 15 segundos;

Ciclo $3-60^{\circ} \mathrm{C}$ por 1 minutos;

Ciclo 4 - repetição dos ciclos 1 - 3 por 30 ciclos.

\subsubsection{Purificação do produto de PCR para o sequenciamento}

A purificação dos produtos de amplificação dos PCRs para o sequenciamento, é realizada acrescentando, $2 \mu \mathrm{L}$ de acetato de sódio 1,5 M pH 4,6 em cada amostra amplificada. O material foi rapidamente agitado e centrifugado por rapidamente. Foi acrescentada a reação $95 \mu \mathrm{L}$ de etanol absoluto e novamente agitado. A placa para o PCR, contendo as reações foi então centrifugada por 45 minutos a 15000 $\mathrm{rpm}$. Após este período o acetato de sódio mais o etanol absoluto foram retirados por um rápido spin com a placa invertida. Adicionou $150 \mu \mathrm{L}$ de etanol $75 \%$ e centrifugou por 15 minutos a $15000 \mathrm{rpm}$. O etanol 75\% foi retirado da placa com o PCR por spin invertido. Após este processo a placa com o PCR foi colocada em estufa a $37^{\circ} \mathrm{C}$ por 1 hora para secagem. Foram adicionados a placa com a reação de PCR purificada $10 \mu \mathrm{L}$ de formanida para o sequenciamento.

O sequenciamento foi realizado pelo seqüenciador 3100 Genetic Analyzer

- Appied Biosystems - Hitachi.

\subsubsection{Solução de Acetato de Sódio}

Acetato de sódio $\mathrm{pH} 4,6$

$\mathrm{O}$ pH foi ajustado para 4,6 e o volume foi completado para $1000 \mathrm{~mL}$ com Água Milli-Q autoclavada. A solução não foi autoclavada e mantida a $4{ }^{\circ} \mathrm{C}$. 
3.5.8.2 Tampão Save money $2,5 \mathrm{x}$

$\begin{array}{ll}\text { Tris } \mathrm{HCl} \text { pH 9,0 } & 200 \mathrm{mM} \\ \mathrm{MgCl}_{2} & 5 \mathrm{mM} \\ \mathrm{MgCl}_{2} 2 \mathrm{M} & 2,5 \mu \mathrm{l} \\ \text { Tris }-\mathrm{HCl} \text { pH 9,0 } & 200 \mu \mathrm{l}\end{array}$

3.5.8.3 Solução estoque de Tris-HCl $1 \mathrm{M} \mathrm{pH} \mathrm{9,0}$

Tris base

$186,1 \mathrm{~g}$

Água Milli-Q autoclavada

$1000 \mathrm{~mL}$

$\mathrm{O} \mathrm{pH}$ foi ajustado para 9,0 com $\mathrm{HCl}$ concentrado, e o volume foi completado para $1000 \mathrm{~mL}$ com Água Milli-Q autoclavada. A solução não foi autoclavada e mantida a $4^{\circ} \mathrm{C}$.

3.5.8.4 Solução de $\mathrm{MgCl}_{2} 2 \mathrm{M}$

$$
\begin{array}{lc}
\mathrm{MgCl}_{2} \text { (Sigma) } & 190,3 \mathrm{~g} \\
\text { Água Milli-Q autoclavada } & 1000 \mathrm{~mL} \\
\mathrm{O} \text { volume foi completado para } 1000 \mathrm{~mL} \text { com Água Milli-Q autoclavada. }
\end{array}
$$

A solução não foi autoclavada e mantida a $4^{\circ} \mathrm{C}$.

\subsubsection{Seqüências}

As seqüências obtidas foram analisadas e depositadas no GeneBank NCBI HomePage http://www.ncbi.nlm.nih.gov/. Os códigos das seqüências encontramse na Tabela 7. 
Tabela 7. Seqüências depositadas no GeneBank - NCBI HomePage

Número da seqüência Seqüências

no NCBI - Gene Bank

AY652421

AY662260

AY662261

AY662262

AY662263

AY662264

AY662265

AY662266

AY662267

AY662268

AY662269

AY662270

AY662271

AY662272

AY662273

AY662274

AY662275

AY662276
Seqüência parcial do gene bristle, variante deteriorado V5

Seqüência parcial do gene niaD, linhagem MSE

Seqüência parcial do gene niaD, mutante $\mathrm{Sx} 11$

Seqüência parcial do gene niaD, mutante $\mathrm{Sx} 12$

Seqüência parcial do gene niaD, mutante $\mathrm{Sx} 12$

Seqüência parcial do gene niaD, mutante Sx16

Seqüência parcial do transposon MATE, linhagem MSE

Seqüência parcial do transposon MATE, linhagem A

Seqüência parcial do transposon MATE, mutante Sx1

Seqüência parcial do transposon MATE, mutante Sx7

Seqüência parcial do transposon MATE, mutante Sx9

Seqüência parcial do transposon MATE, mutante Sx10

Seqüência parcial do transposon MATE, mutante Sx13

Seqüência parcial do transposon MATE, mutante Sx14

Seqüência parcial do transposon MATE, mutante Sx15

Seqüência parcial do transposon MATE, mutante Sx18

Seqüência parcial do transposon MATE, mutante Sx19

Seqüência parcial do transposon MATE, mutante Sx23 


\section{RESULTADOS E DISCUSSÃO}

\subsection{Análise Macroscópica das Colônias}

O isolamento dos setores deteriorados foram realizados por inoculação da linhagem A por um ponto central em placas de Petri, contendo meio completo (item 3.2.5.2) e incubado a $37^{\circ} \mathrm{C}$ por 7 dias.Os variantes deteriorados V101, V102, V103 e V104 foram obtidos por Giancoli (2000) e o variante deteriorado V5 foi obtido por Azevedo \& Roper (1970). Os variantes deteriorados foram numerados de acordo com a nomenclatura seguida por Azevedo \& Roper (1970). As características morfológicas das colônias, como: coloração do micélio e conídios, conidiação, origem e tipos de setores produzidos estão sumarizados na Tabela 8 e na Figura 6.

\subsection{Análise Genética}

Para a análise genética foram utilizados os variantes deteriorados selecionados efetuando-se os cruzamentos com a linhagem testadora MSE, que possui marcadores em todos os grupos de ligação. Inicialmente foi realizado o teste de auxotrofia, para verificação dos marcadores genéticos de cada linhagem (Tabela 9). 
Tabela 8. Descrição morfológica dos variantes deteriorados isolados da linhagem A de A. nidulans

\begin{tabular}{cl}
\hline Variante deteriorado & \multicolumn{1}{c}{ Morfologia } \\
\hline V5 & Borda irregular, micélio avermelhado, esporulação escassa, conídios \\
& verdes e produto de excreção no meio de cultura com coloração \\
& vermelhada. \\
V101 & Borda irregular, micélio marrom muito claro, esporulação escassa, \\
& conídios amarelos. \\
V102 & Borda irregular, micélio avermelhado, esporulação média, conídios \\
& brancos e produto de excreção no meio de cultura com coloração \\
& vermelhada. \\
V103 & Borda irregular, micélio branco, esporulação média, conídios verde. \\
V104 & Borda regular, micélio branco, esporulação escassa, conídios \\
& brancos. \\
\hline
\end{tabular}
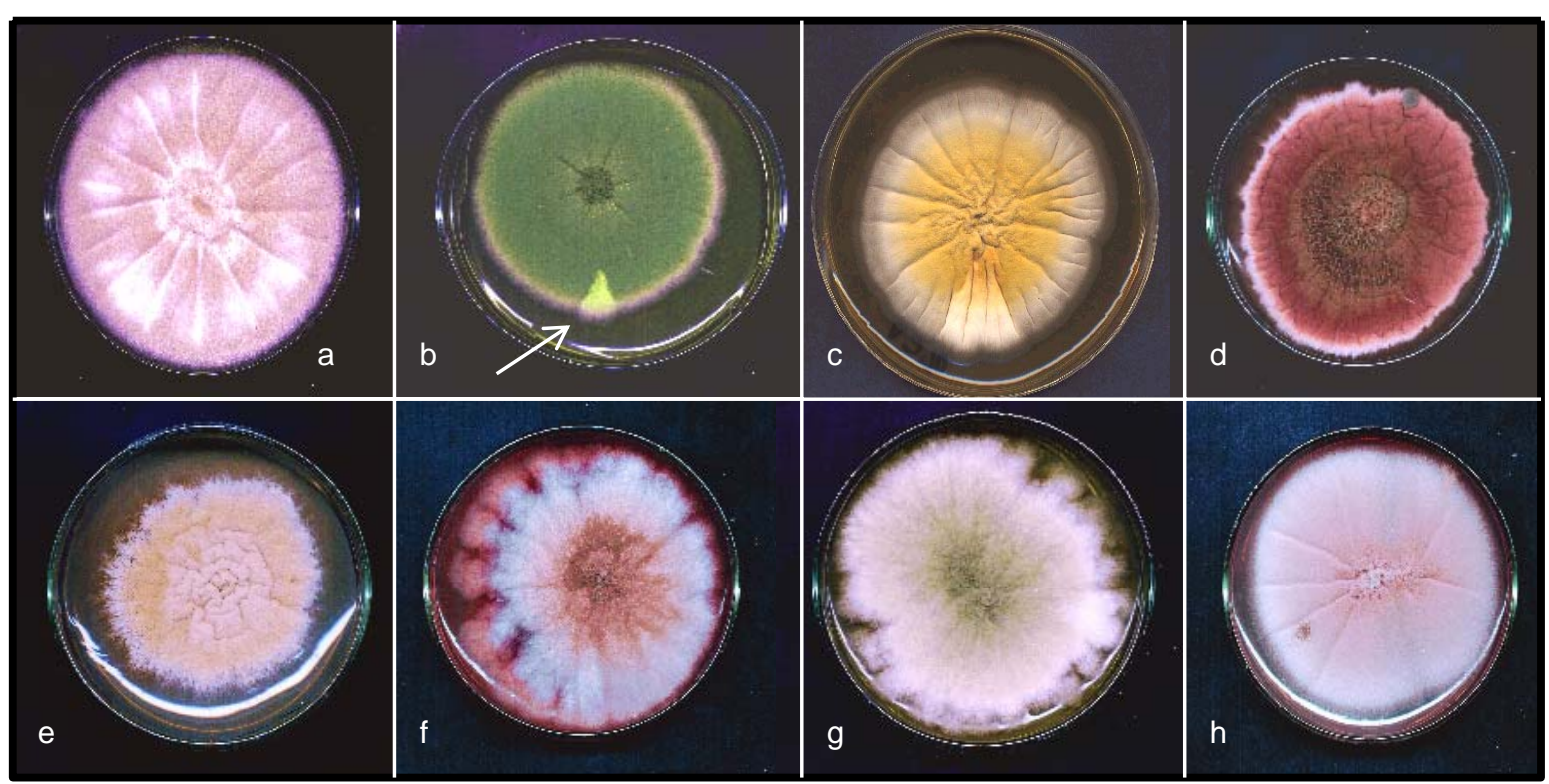

Figura 6 - Fotos das linhagens padrões $(a-c)$ e variantes deteriorados $(d-h)$. a) MSE; b) A; c) PPY; d) V5; e) V101; f) V102; g) V103; h) V104. As linhagens foram crescidas por 7 dias a temperatura de $37^{\circ} \mathrm{C}$. A seta indica um setor melhorado 
Tabela 9. Teste de Auxotrofia dos Variantes deteriorados e das linhagens padrões

\begin{tabular}{cccccccccccc}
\hline Linhagens & pro & paba & gal & fac & pyro & s & nic & ribo & bi & niaD & brl \\
\hline MSE & + & + & - & - & - & - & - & - & + & + & + \\
A & - & - & + & + & + & + & + & + & + & + & + \\
PPY & - & - & + & + & + & + & + & + & + & + & + \\
G125 & + & + & + & + & + & + & + & + & - & - & + \\
G0248 & + & + & + & + & + & + & + & + & - & + & - \\
V5 & - & - & + & + & + & + & + & + & + & + & + \\
V101 & - & - & + & + & + & + & + & + & + & + & + \\
V102 & - & - & + & + & + & + & + & + & + & + & + \\
V103 & - & - & + & + & + & + & + & + & + & + & + \\
V104 & - & - & + & + & + & + & + & + & + & + & + \\
\hline
\end{tabular}

\subsubsection{Análise Mitótica}

Por meio do ciclo parassexual (Roper, 1952), formam obtidos segregantes haplóides utilizando-se $\rho$ - fluorfenilalanina (item 3.2). Os resultados das análises mitóticas se encontram na Tabela 10.

\subsubsection{Análise Meiótica}

Por meio do ciclo sexual (Pontecorvo et al., 1953), foram obtidos os valores de recombinação dos determinantes de deterioração com os marcadores genéticos conhecidos. As placas de Petri com as películas heterocarióticas, para análise meiótica permaneceram incubadas por 12 dias a $37^{\circ} \mathrm{C}$. Após esse período, foi possível observar os cleistotécios (item 3.2), mas nas linhagens deterioradas os cleistotécios apresentam algumas características incomuns, como: menor quantidade de cleistotécios quando comparado com cruzamentos padrões (MSE x PPY), cleistotécios mais frágeis (ruptura muito fácil) e tamanho reduzido.

Os dados da segregação meiótica encontram-se na Tabela 11. A proporção esperada de segregantes normais e variantes deteriorados foi de 1:1, sendo aplicado o teste 
de $\chi^{2}$ para detectar se os desvios encontrados ocorrem ao acaso. Caso essa proporção não fosse seguida, o teste de $\chi^{2}$ seria aplicado à proporção de $2: 1$.

Tabela 10. Análise Mitótica. Localização dos determinantes de deterioração nos grupos de ligação

\begin{tabular}{|c|c|}
\hline & Grupo de Marcadores Genéticos $\mathrm{V}$ \\
\hline
\end{tabular}
Ligação

\begin{tabular}{|c|c|c|c|c|c|c|c|c|c|c|c|}
\hline & & $\mathrm{N}$ & $\mathrm{D}$ & $\mathrm{N}$ & $\mathrm{D}$ & $\mathrm{N}$ & $\mathrm{D}$ & $\mathrm{N}$ & $\mathrm{D}$ & $\mathrm{N}$ & $\mathrm{D}$ \\
\hline \multirow[t]{2}{*}{ I } & pro $^{+}$paba $^{+}$ & 17 & 9 & 19 & 5 & 8 & 5 & 27 & 5 & 12 & 1 \\
\hline & pro $^{-}$paba- & 0 & 0 & 1 & 1 & 5 & 2 & 14 & 3 & 1 & 8 \\
\hline \multirow[t]{2}{*}{ II } & $w^{+}$ & 9 & 9 & 8 & 6 & 4 & 7 & 13 & 17 & 6 & 9 \\
\hline & $w^{-}$ & 7 & 0 & 12 & 0 & 9 & 0 & 19 & 0 & 7 & 0 \\
\hline \multirow[t]{2}{*}{ III } & $g a l^{+}$ & 0 & 2 & 1 & 5 & 0 & 1 & 10 & 5 & 6 & 6 \\
\hline & $\mathrm{gal}^{-}$ & 17 & 7 & 19 & 1 & 13 & 6 & 22 & 12 & 7 & 2 \\
\hline \multirow[t]{2}{*}{ IV } & pyro $^{+}$ & 13 & 7 & 10 & 6 & 1 & 6 & 27 & 11 & 10 & 8 \\
\hline & pyro $^{-}$ & 4 & 2 & 10 & 0 & 13 & 0 & 5 & 6 & 3 & 1 \\
\hline \multirow[t]{2}{*}{$\mathrm{V}$} & $f a c^{+}$ & 3 & 7 & 12 & 5 & 4 & 3 & 15 & 12 & 7 & 5 \\
\hline & $f a c^{-}$ & 14 & 2 & 8 & 1 & 9 & 4 & 17 & 5 & 6 & 4 \\
\hline \multirow[t]{2}{*}{ VI } & $s^{+}$ & 7 & 8 & 18 & 6 & 12 & 7 & 25 & 15 & 10 & 6 \\
\hline & $s^{-}$ & 10 & 1 & 2 & 0 & 1 & 0 & 7 & 2 & 3 & 3 \\
\hline \multirow[t]{2}{*}{ VII } & $\operatorname{nic}^{+}$ & 13 & 9 & 17 & 4 & 9 & 4 & 1 & 14 & 10 & 6 \\
\hline & $n i c^{-}$ & 4 & 0 & 3 & 2 & 4 & 3 & 31 & 3 & 3 & 3 \\
\hline \multirow[t]{2}{*}{ VIII } & $\mathrm{ribo}^{+}$ & 3 & 9 & 17 & 4 & 11 & 4 & 27 & 12 & 11 & 8 \\
\hline & ribo $^{-}$ & 14 & 0 & 3 & 2 & 2 & 3 & 5 & 5 & 2 & 1 \\
\hline Total & & 17 & 9 & 20 & 6 & 13 & 7 & 32 & 17 & 13 & 9 \\
\hline
\end{tabular}


Tabela 11. Resultado das Análises Meióticas

\begin{tabular}{|c|c|c|c|c|c|c|}
\hline Variante & Grupo & Marcador & Segregação & Freqüência de & $\chi^{2}$ & $\chi^{2}$ \\
\hline \multirow[t]{2}{*}{ Deteriorado } & de & Genético & Meiótica & Recombinação & $1: 1$ & $1: 2$ \\
\hline & Ligação & & Normal:Deteriorado & & & \\
\hline \multirow[t]{2}{*}{ V5 } & VIII & ribo & $62: 42$ & 27,88 & $3,9 *$ & $13,0 * *$ \\
\hline & & & & & $\mathrm{n} / \mathrm{s} 1$ & \#\# \\
\hline \multirow[t]{2}{*}{ V101 } & III & gal & $88: 42$ & 13,3 & $13,4 * *$ & $5,41 *$ \\
\hline & & & & & \# & $\mathrm{ns} / 1$ \\
\hline \multirow[t]{2}{*}{ V102 } & IV & pyro & $52: 26$ & 10,25 & $8,6 * \#$ & $2,8^{\mathrm{n} / \mathrm{s}}$ \\
\hline & & & & & & $\mathrm{n} / \mathrm{s} 1$ \\
\hline \multirow[t]{2}{*}{ V103 } & VII & nic & $78: 52$ & 13,38 & $5,2 *$ & $15,6 * *$ \\
\hline & & & & & $\mathrm{ns} / 1$ & $\# \#$ \\
\hline \multirow[t]{2}{*}{ V104 } & I & pro paba & $52: 26$ & 14,10 & $8,6 * \#$ & $2,88^{\mathrm{n} / \mathrm{s}}$ \\
\hline & & & & & & $\mathrm{n} / \mathrm{s} 1$ \\
\hline
\end{tabular}

$\alpha+5 \%$, Gl 1, * significativo, $* *$ altamente significativo, $\mathrm{n} / \mathrm{s}$ não significativo $\alpha+1 \%$, G1 1, ${ }^{\#}$ significativo, ${ }^{\# \#}$ altamente significativo, $\mathrm{n} / \mathrm{s} 1$ não significativo

A formações de setores são típicos de linhagens com duplicação cromossômica, e algumas explicações podem ser colocadas para elucidar este evento, como: deleções terminais, mutações, permuta mitótica, permuta desigual entre cromátides irmãs, inversões, novas duplicações em tandem ou transposição do segmento cromossomo em duplicata (Nga \& Roper, 1966; Nga \& Roper, 1968a, b; Azevedo \& Roper, 1970). Azevedo \& Roper (1970) iniciaram os estudos com os variantes deteriorados originários da linhagem A de A. nidulans, seguindo esta linha de pesquisa diversos autores (Menezes, 1974; Niffinegger e Souza, 1979; Paccola, 1982; Monteiro, 1989; Pascon, 1994; Giancoli, 2000) deram continuidade analisando genética e citologicamente os setores emitidos pela linhagem A.

Atualmente já foram analisados 104 setores deteriorados (nomenclatura segue trabalho de Azevedo \& Roper, 1970), sendo que os determinantes de deterioração dos variantes deteriorados analisados, foram encontrados em todos os oito grupos de ligação 
de A. nidulans, isto comprova que o determinante de deterioração "salta" pelos oitos cromossomos de A. nidulans, apresentando comportamento semelhante aos transposons de bactérias (seqüências de inserção - IS) e a alguns transposons descritos em fungos filamentosos, como o Impala de Fusarium oxysporum (Daboussi \& Capy, 2003).

A análise genética dos variantes deteriorados deste trabalho, V5, V101, V102, V103 e V104, demonstraram que estes apresentam-se relativamente estáveis. Os variantes deteriorados analisados mostraram um único determinante de deterioração, sendo estes, localizados no grupo de ligações VIII, III, IV, VII e I respectivamente.

Por meio do teste de $\chi^{2}$ foi possível demonstrar que ocorrem desvios significativos para as proporções analisadas de 1:1 e 1:2 (Tabela 11). Paccola (1982) e Monteiro (1989), analisando geneticamente variantes deteriorados, obtiveram resultados semelhantes, descrevendo a presença de aberrações cromossômicas heterozigotas nos cruzamentos. Os desvios ocorridos nas proporções esperadas podem ter como conseqüência a produção de ascos com um número inferior a oito, ou ascos contendo vários ou todos os ascósporos defectivos.

O variante deteriorado V5 foi analisado mais detalhadamente. Segundo Azevedo \& Roper (1970), o determinante de deterioração encontra-se no grupo de ligação VIII, com freqüência de recombinação de 29,0 cM da marca ribo. Análises genéticas realizadas por Molina (1993), verificou que o determinante de deterioração do V5 estava envolvimento com o grupo de ligação I com os marcadores pro paba, no referido trabalho não foi verificada a ligação do determinante de deterioração ao marcador ribo, presente no cromossomo no oito. Queiroz et al., (2000) realizaram análises de linhagens duplicadas de variantes deteriorados de A. nidulans, por meio da técnica de eletroforese de campo pulsado, permitindo a separação cromossomos em bandas. Neste trabalho foram analisadas as linhagens com duplicação cromossômica A e B e os variantes deteriorados V5 e V17. O V5 apresentou redução no tamanho do cromossomo I, comprovando a deleção na região duplicada presente neste cromossomo. O tamanho aproximado da deleção foi calculada em $1 \mathrm{Mb}$, sendo esta região translocada para o cromossomo IV. Devido aos resultados obtidos por estes autores, no presente trabalho foi realizado o cruzamento entre o variante deteriorado V5 e a linhagem 
testadora MSE, os resultados da análise genética condizem com os dados de Azevedo \& Roper (1970), isto é, o determinante de deterioração se encontra no cromossomo VIII. Uma provável explicação para as diferenças encontradas nas análises genéticas realizadas pelos autores, é que o variante deteriorado V5 não é totalmente estável, sendo que freqüentemente emite setores, esta instabilidade está relacionada com o determinante de deterioração, que apresenta comportamento característico de elementos de transposição. Para verificar se o determinante de deterioração realmente encontra-se no grupo de ligação VIII, realizou o cruzamento do variante deteriorado V5 com as linhagens G125 e G0248. Durante a análise mitótica V5 // G0248, todos os segregantes haplóides obtidos por $\rho$-fluorfenilalanina apresentavam características morfológicas da linhagem G0248. Alguns segregantes haplóides foram analisados microscopicamente, e todos apresentavam conidióforos característicos de "bristle" brando os quais são muito semelhantes ao conidióforo do variante deteriorado V5 (Figura 7).

Os dados obtidos das Análises Genéticas (cruzamento V5 x G125 e V5 x G0248) (Tabelas 12 e 13) comprovam que o determinante de deterioração se encontra no grupo de ligação VIII, precisamente no gene para desenvolvimento "bristle”.

Tabela 12. Análise Mitótica V5 // G125 (biA 1 , niaD15).

\begin{tabular}{cccc}
\hline Grupo de Ligação & Marcadores Genéticos & $\mathrm{N}$ & $\mathrm{D}$ \\
\hline I & pro $^{+}$paba $^{+}$ & 10 & 3 \\
& pro $^{-}$paba $^{-}$ & 6 & 9 \\
I & biA $_{1}^{+}$ & 10 & 8 \\
& biA $_{1}^{-}$ & 6 & 4 \\
VIII & niaD15 & 12 \\
& niaD15 & 1 & 0 \\
\hline Total & & 15 & 12
\end{tabular}

$$
\begin{aligned}
& \mathrm{N}=\text { normal } \\
& \mathrm{D}=\text { deteriorado }
\end{aligned}
$$


Tabela 13. Resultado das Análises Genéticas

\begin{tabular}{ccccccc}
\hline Variante & Grupo & Marcador & Segregação & Freqüência de & $\chi^{2}$ & $\chi^{2}$ \\
Deteriorado & de & Genético & Meiótica & Recombinação & $1: 1$ & $1: 2$ \\
& Ligação & & Normal:Deteriorado & & & \\
\hline V5 & VIII & niaD15 & $84: 20$ & 16,34 & $36,9,,^{* * \#}$ & $1,3^{\text {n/s n/s1 }}$ \\
V5 & VIII & brlA42 & 72 & 0,0 & - & - \\
\hline
\end{tabular}

$\alpha+5 \%$, G1 1, * significativo, ** altamente significativo, $\mathrm{n} / \mathrm{s}$ não significativo

$\alpha+1 \%$, G1 1, " significativo, ${ }^{\# \#}$ altamente significativo, $\mathrm{n} / \mathrm{s} 1$ não significativo

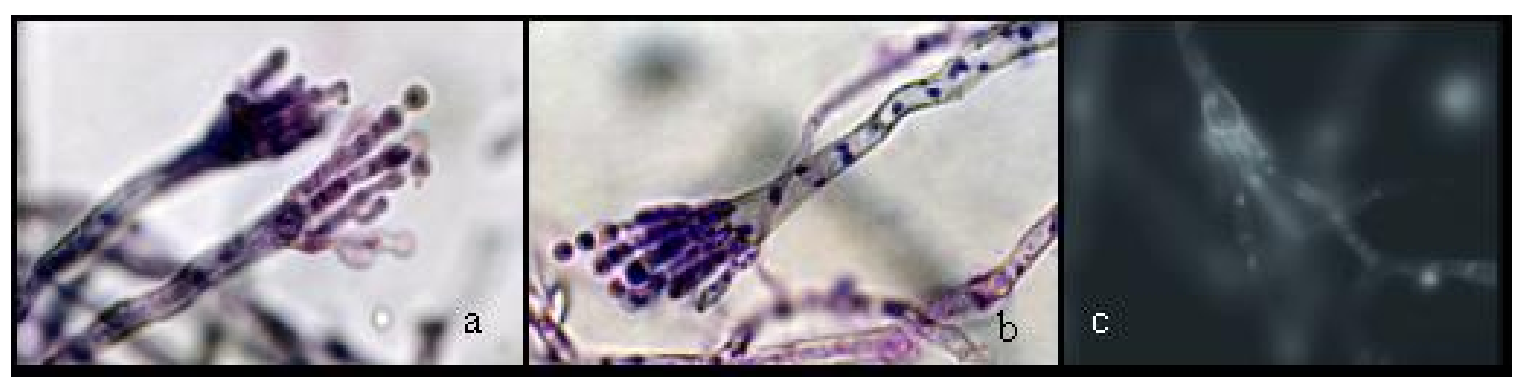

Figura 7 - Micrografia. (a) conidióforo da linhagem G0248 (b - c) conidióforo do variante deteriorado V5. (a - b) coloração de Giemsa, (c) coloração DAPI/calcofluor. Aumento de 1000x.

\subsubsection{Análise Molecular do Variante Deteriorado V5}

Os dados obtidos pela análise genética mostram que o determinante de deterioração do V5 poderia estar inserido no gene para o desenvolvimento do conidióforo bristle. Para tentarmos localizar o segmento de inserção ou determinante de deterioração, foi realizada PCR com primers específicos (item 3.5.4.2) para o gene bristle, e sequenciamento do produto de amplificação.

A comparação da seqüência de nucleotídeos do produto de amplificação do variante deteriorado V5 com a seqüência do alelo selvagem descrita por Adams et al. (1988) não demonstrou qualquer segmento de inserção nesta região (Anexo B e E). 


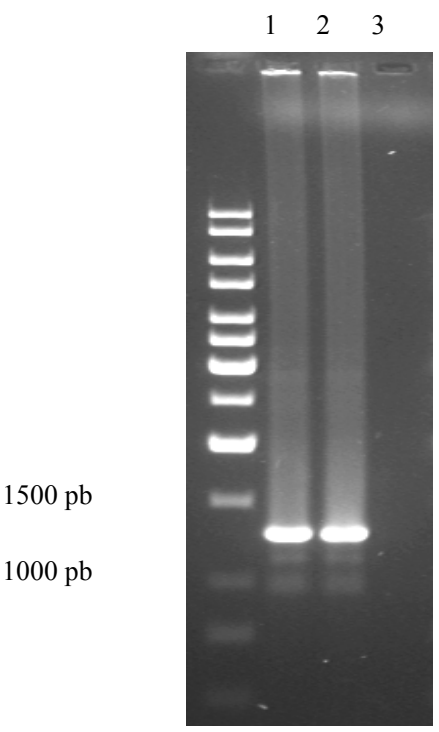

Figura 8 - PCR com primers BrlF - BrlR. (a) MSE, (b) V5, (c) branco. Fragmento com aproximadamente $1300 \mathrm{pb}$

\subsection{Analise Citológica}

\subsubsection{Análise Macroscópica}

O desenvolvimento do ciclo vegetativo do fungo homotálico A. nidulans pode ocorrer por meio de fragmentos de hifas, esporos sexuais e assexuais.

A etapa inicial para este estudo foi a caracterização das linhagens padrões e variantes deteriorados, sob o ponto de vista macroscópico das colônias. As colônias foram inoculadas em meio completo sólido e crescidas a $28^{\circ} \mathrm{C}$ (temperatura permissiva), $37^{\circ} \mathrm{C}$ (temperatura ideal) e $42^{\circ} \mathrm{C}$ (temperatura restritiva) por 5 dias. A. nidulans é capaz de crescer dentro de um amplo espectro de temperaturas que, segundo Eidam (1883) a temperatura ótima está em torno dos $40^{\circ} \mathrm{C}$, enquanto Pontecorvo et al. (1953) recomendaram temperaturas entre $36^{\circ} \mathrm{C}$ e $37^{\circ} \mathrm{C}$, o que é seguido até hoje na maioria dos laboratórios. A temperatura é um fator importante para a germinação, desenvolvimento e conidiogênese, visto que em culturas submersas, a indução da formação de conidióforos 
pode ser induzida por choque de temperatura alta ("heat shock") (Martinelli, 1976). Yager et al. (1982) descreveram muitos mutantes sensíveis a temperatura mais baixa ou permissiva $\left(20^{\circ} \mathrm{C}-28^{\circ} \mathrm{C}\right)$, estas mutações estão relacionadas com as diversas fases de desenvolvimento, temperaturas de $42^{\circ} \mathrm{C}$ ou acima, produzem o efeito de impedir o desenvolvimento de A. nidulans. As variações das temperaturas no crescimento da linhagem A e variantes deteriorados analisados neste trabalho, podem evidenciar mutantes para o ciclo celular e migração nuclear.

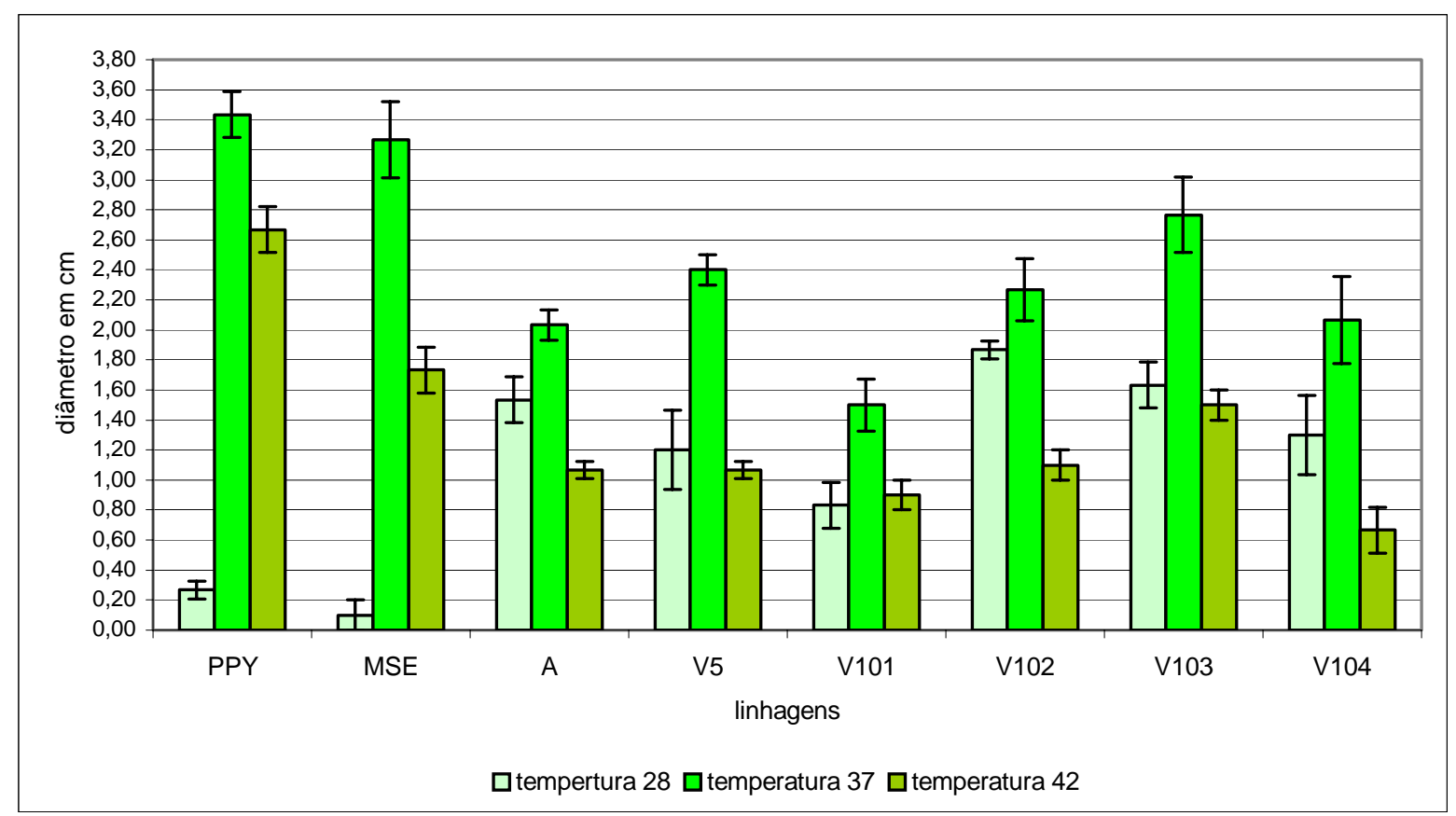

Figura 9 - Análise do crescimento das colônias padrões e variantes deteriorados em diferentes temperaturas $(\mathrm{cm})$. Linhagens padrões PPY, MSE e A; variantes deteriorados V5, V101, V102, V103 e V104. As barras indicam o desvio padrão (média de três repetições)

A maiorias dos estudos realizados com a instabilidade de $A$. nidulans estão voltados para a análise genética, mas a presença de segmentos em duplicata no genoma desta espécies pode acarretar alterações na formação e funcionamento do ciclo e migração celular, além de alterações no desenvolvimento das estruturas relacionadas ao ciclo 
assexual e sexual (Niffinegger e Souza, 1979; Pascon 1994; Giancoli, 2000). Com este objetivo, a linhagem A e os variantes deteriorados, foram analisados (Figura 9) em relação ao seu crescimento em diferentes temperaturas. A temperatura de $37^{\circ} \mathrm{C}$ foi considerada ideal para as linhagens que não apresentam duplicação cromossômica, o mesmo não correu com a linhagem A. Os dados apresentados mostram que a presença da duplicação cromossômica causa alterações na taxa de crescimento, confirmando resultados de Bainbridge \& Roper (1966), Nga \& Roper (1968a, b) e Niffinegger e Souza (1979). Os variantes deteriorados em geral apresentaram taxas de crescimento melhores do que a linhagem A (com exceção do V101), do qual tiveram origem. Em relação às linhagens MSE e PPY (sem duplicação cromossômica) podemos observar que osdeteriorados e alinhagem A têm crescimento superior na temperatura de $28^{\circ} \mathrm{C}$. Os resultados (Figura 9) mostram a ocorrência de variabilidade de crescimento entre os deteriorados, este fato pode ser explicado pela possível perda ou transposição do segmento duplicado, o que acarreta em favorecimento no crescimento dos variantes deteriorados em meio completo a temperatura de $37^{\circ} \mathrm{C}$.

A temperatura permissiva de $28^{\circ} \mathrm{C}$, afetou mais drasticamente as linhagens padrões PPY e MSE (não apresentam duplicação cromossômica). A linhagem A (duplicação cromossômica) não apresentou crescimento tardio drástico, sendo o mesmo observado para os variantes deteriorados. Este evento pode estar relacionado com a duplicação cromossômica presentes nas linhagens. Estudos realizados por Bonatelli \& Azevedo (1977) e Niffinegger e Souza (1979) demonstraram que a temperatura em torno de $30^{\circ} \mathrm{C}$ tende a estabilizar as linhagens portadoras de duplicação cromossômica.

A temperatura restritiva de $42^{\circ} \mathrm{C}$ afetou de modo geral o crescimento das linhagens MSE e PPY, mas não de forma tão drástica como a temperatura de $28^{\circ} \mathrm{C}$, isto comprovam os dados de Eidam (1883) em que temperaturas em torno de $40^{\circ} \mathrm{C}$ podem ser ideais para algumas linhagens de A. nidulans. Para a linhagem A e os variantes deteriorados V5, V102, V103 e V104, esta temperatura bloqueou mais o crescimento do micélio, quando comparado com a temperatura de $28^{\circ} \mathrm{C}$, fato que também pode estar relacionado com a presença e transposição do determinante de deterioração ou segmento de inserção. 


\subsubsection{Germinação do conídio em meio completo líquido}

Este método foi utilizado para estimar o tempo e a capacidade de germinação inicial das linhagens padrões e dos variantes deteriorados em diferentes temperaturas, $28^{\circ} \mathrm{C}$ (temperatura permissiva), $37^{\circ} \mathrm{C}$ (temperatura ideal) e $42^{\circ} \mathrm{C}$ (temperatura restritiva). $\mathrm{O}$ tempo de germinação estipulado foi de 6 horas em meio completo líquido sem agitação, foram inoculados $10^{6}$ conídios $/ \mathrm{mL}$, o padrão estabelecido para análise foi o início da emissão do tubo germinativo. Após o período estipulado, foram retiradas alíquotas das amostras e analisadas ao microscópio. A Figura 10 apresenta os resultados obtidos (média de três repetições).

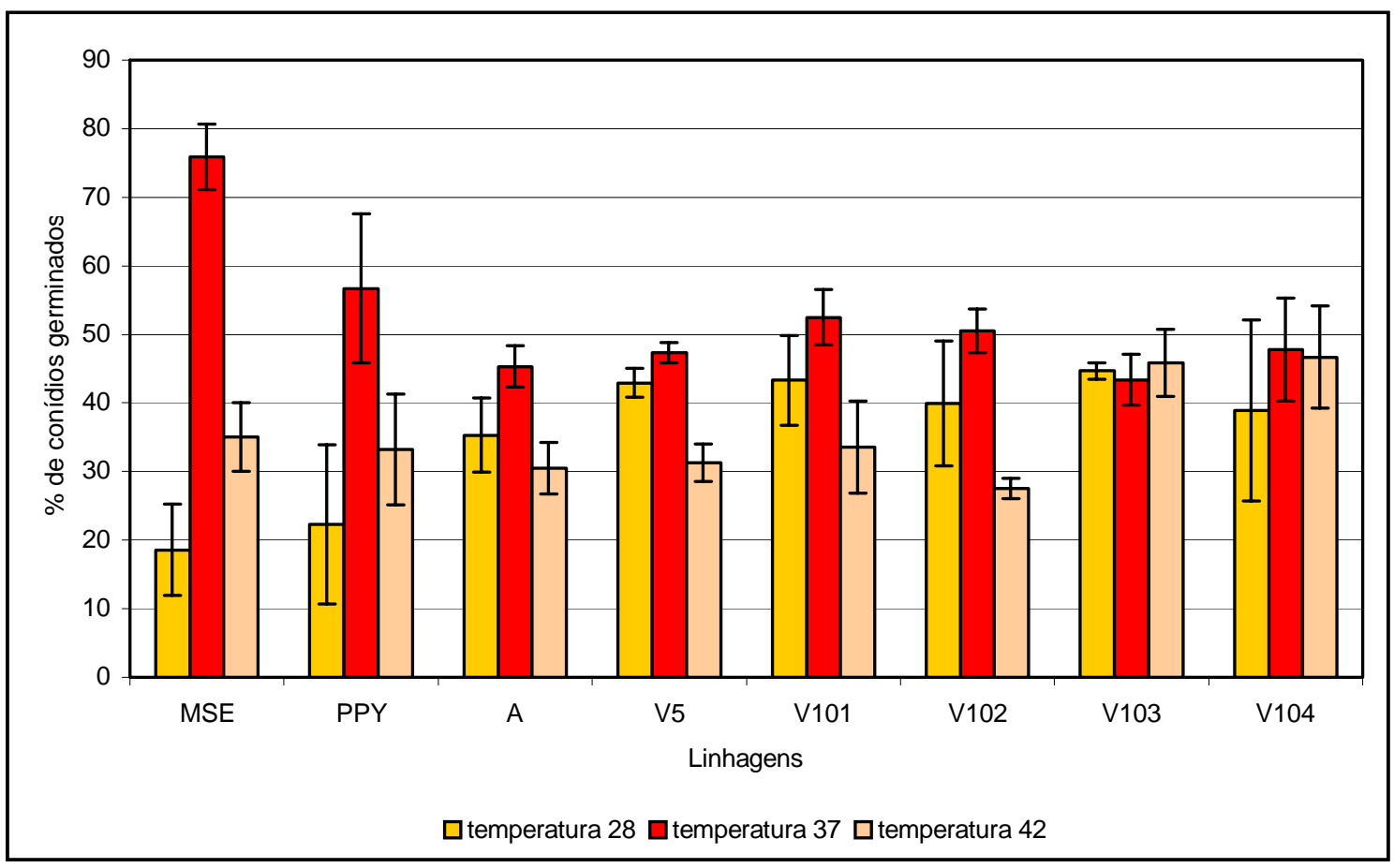

Figura 10 - Análise em porcentagem dos conídios germinados com 6 horas de crescimento em diferentes temperaturas. Linhagens padrões PPY, MSE e A; variantes deteriorados V5, V101, V102, V103 e V104 
Os resultados das análises da germinação dos conídios em diferentes temperaturas (Figura 10) mostraram que, a partir de 6 horas de incubação, nas diferentes temperaturas, os conídios já estavam germinando.

Na temperatura de $37^{\circ} \mathrm{C}$ (ideal) as linhagens MSE e PPY tiveram uma alta porcentagem de germinação. A linhagem A e variantes deteriorados (Figura 9), tiveram uma porcentagem de germinação menor, quando comparados com PPY e MSE. A linhagem A teve a menor porcentagem de germinação dos conídios, isto se deve à presença da duplicação cromossômica que deve bloquear algumas das fases iniciais de germinação. Nos variantes deteriorados a porcentagem de germinação foi um pouco maior, provavelmente devido a translocação do determinante de deterioração.

A temperatura de $28^{\circ} \mathrm{C}$, ocorreu o resultado semelhante ao do experimento de crescimento da colônia, sendo que as MSE e PPY apresentaram germinação inferior. A linhagem A e os determinantes de deterioração apresentaram germinação maior que as linhagens sem duplicação cromossômica, este fato, já mencionado anteriormente, esta relacionado com a presença do determinante de deterioração e com a duplicação cromossômica.

A temperatura de $42^{\circ} \mathrm{C}$, no estado inicial de germinação afetou menos as linhagens MSE e PPY, a linhagem A e os variantes deteriorados V5, V101 e V102, ocorreu uma queda na porcentagem de conídios germinados, quando comparados com as temperaturas de $28^{\circ} \mathrm{C}$ e $37^{\circ} \mathrm{C}$, isto indica que nas fases iniciais de germinação o fator temperatura tende a atuar de forma mais seletiva nestas linhagens.

Fato interessante ocorreu com os determinantes de deterioração V103 e V104, ambos apresentaram porcentagem de germinação (Figura 10) muito próxima nas três temperaturas analisadas, com o período de 6 horas de incubação. Aparentemente a variação de temperaturas analisada neste experimento, não interfere no padrão de germinação destes dois variantes deteriorados, este evento pode estar relacionado com o determinante de deterioração. Para melhor compreender os mecanismos de variação de temperatura seria interessante subdividir este experimento em intervalos de tempo menores, como com períodos de 2, 4, 6, 8 horas de desenvolvimento, estabelecendo uma curva de germinação mais detalhada. Entretanto, como o objetivo do ensaio era tentar correlacionar alterações no 
crescimento (Figura 9) com a capacidade de germinação (Figura 10), os métodos utilizados justificam-se, e demonstram semelhança entre os dois gráficos analisados.

Do exposto, algumas considerações podem ser apresentadas: a presença da duplicação cromossômica interfere tanto na germinação quanto no crescimento da linhagem A e dos variantes deteriorados na temperatura de $37^{\circ} \mathrm{C}$ e $42^{\circ} \mathrm{C}$. Nas temperaturas de $28^{\circ} \mathrm{C}$ ocorre o inverso, a linhagem com duplicação cromossômica e os variantes deteriorados apresentam germinação e crescimento melhor do que as linhagens sem duplicação cromossômica. Apenas os variantes deteriorados V103 e V104 não apresentam grandes alterações, nas três temperaturas analisadas em relação ao inicio da germinação dos conídios (Figura 10), durante o crescimento micelial o variante deteriorado V103 apresenta pouca variação de desenvolvimento nas temperaturas de $28^{\circ} \mathrm{C}$ e $42^{\circ} \mathrm{C}$ (Figura 9), enquanto que no variante deteriorado V104 as duas temperaturas atuam de forma marcante. Com $28^{\circ} \mathrm{C}$ ocorre um desenvolvimento micelial maior, enquanto que a temperatura de $42^{\circ} \mathrm{C}$ bloqueia este crescimento. Podemos levantar a hipótese, que os variantes deteriorados V103 e V104, que não apresentaram variações drásticas durante a germinação dos conídios tanto em temperatura permissiva $\left(28^{\circ} \mathrm{C}\right)$ quanto restritiva $\left(42^{\circ} \mathrm{C}\right)$, devem apresentar expressão diferencial da proteína RAS, a qual é responsável por desencadear o processo MAPK, promovendo todo o desenvolvimento do conídio (germinação, desenvolvimento micelial, divisão e migração nuclear) (Osherov \& May, 2000 e 2001). Para comprovarmos esta hipótese seriam necessários testes moleculares e bioquímicos para estabelecer a expressão de RAS.

\subsubsection{Análise Microscópica}

Durante a execussão deste trabalho, foram caracterizadas as primeiras horas de desenvolvimento das linhagens estudadas, para observar o padrão de germinação e determinar a cinética de divisão nuclear. A parte inicial deste experimento foi conduzida utilizando meio completo líquido e crescimento das linhagens a $37^{\circ} \mathrm{C}$, sem agitação e as amostras para estudos foram coletadas nos tempos zero, $2,4,6,8,12$ e 16 horas. Nos 
intervalos de tempo de 20 e 32 horas, os conídios de cada amostra foram inoculados em meio completo sólido sobre lamínulas e incubados a $37^{\circ} \mathrm{C}$.

Em uma segunda análise, os conídios de cada linhagem foram inoculados em meio completo líquido e incubados à temperatura de $28^{\circ} \mathrm{C}$ (permissiva) e $42^{\circ} \mathrm{C}$ (restritiva). As amostras foram retiradas em intervalos de tempo pré-determinados: 4, 8 e 12 horas, sendo fixadas e coradas segundo a técnica de DAPI/Calcofluor, a qual permite coloração de núcleos, parede celular e septos.

\subsubsection{Análise das linhagens padrões}

As análises da germinação, ciclo celular e migração nuclear iniciaram-se com as linhagens padrões MSE, PPY e A. A linhagem PPY foi utilizada para comparação com a linhagem A, a qual apresenta duplicação cromossômica e as marcas pro paba, e deste modo poderia apresentar alguma alteração no padrão de germinação. Entretanto a linhagem A, apesar de apresentar a duplicação cromossômica, não foi detectada nenhuma alteração estrutural durante as fases iniciais do desenvolvimento (ciclo celular e migração nuclear), mas como visto anteriormente ocorre alteração temporal (atraso) na germinação dos conídios, mas esta alteração não foi observada no desenvolvimento do conidióforo (Giancoli, 2000).

Os resultados da germinação e desenvolvimento das linhagens padrões estão apresentados na Figura 11. As três linhagens MSE, PPY e A apresentam germinação e desenvolvimento semelhantes à temperatura de $37^{\circ} \mathrm{C}$. Inicialmente, entre o período zero e 2 horas ocorre o aumento do volume do esporo. Com aproximadamente 2 horas de germinação foi possível observar as primeiras divisões mitóticas e o desenvolvimento do tubo germinativo com 4 horas de germinação (Figura 11 b, c, d, j, k, n) (Harris, 1997a; Harris \& Hofmann, 1999a; Harris, 2001). A partir de 4 horas de germinação estabeleceu-se o desenvolvimento vegetativo e ocorreram as primeiras divisões mitóticas, sendo este o tempo necessário para a quebra completa da dormência. Após aproximadamente 8 horas de germinação observamos grande aumento do volume citoplasmático, além da emissão do tubo germinativo, com a migração gradual dos núcleos filhos (Figura 11 d, e, 1) (Fiddy \& Trinci, 1976). 
As formações dos tubos germinativos ocorrem nestas linhagens entre os períodos de 4 - 6 horas de germinação, ao mesmo tempo em que ocorre a segunda divisão mitótica. O tubo germinativo apresenta desenvolvimento apical, estabelecimento um eixo de crescimento polarizado na ponta do tubo germinativo, fazendo com que a hifa cresça nesta direção pela deposição de parede celular (Gooday, 1983; Fiddy \& Trinci, 1976). A formação dos septos ocorre entre os períodos de 6 - 8 horas, estes são responsáveis por delimitarem o micélio, e cada célula delimitada apresenta de 2 a 10 núcleos. A delimitação não é completa pela formação de poros que proporcionam a passagem de organelas e núcleos entre as células (Figura $11 \mathrm{~g}, 1)$ (Morris, 1976). Após o desenvolvimento do primeiro tubo germinativo, um segundo tubo é emitido em orientação oposta ao primeiro (Figura $11 \mathrm{f}, \mathrm{o}$ ) (Pontecorvo et al., 1953; Morris et al., 1995).

A partir de 8 horas de germinação ocorre o desenvolvimento e ramificação das hifas dando origem ao micélio vegetativo. Rosenberg \& Kessel (1967) demonstraram que enquanto a hifa se expande na região apical, os núcleos que ficam nos compartimentos distais entram em dormência, isto é, não ocorre divisão mitótica. Porém os núcleos presentes nas pontas das hifas estão mitoticamente ativos, continuando a dividir-se de modo semi-sincrônico e fazendo parte dos compartimentos septados. Os núcleos presentes nos compartimentos distais podem eventualmente, voltar a se dividir para formar as ramificações laterais da hifa, mas primeiro é necessário que se estabeleça um pólo de crescimento. A partir do momento em que o tubo germinativo se ramifica, as pontas da hifa deixam de ser o único sítio de crescimento polarizado e, então, o micélio passa a ter vários pontos de crescimento ativo, e a colônia vai adquirindo o seu aspecto circular quando crescida em meio de cultura sólido (Figura 12 h, i, m, p) (Harris \& Kraus, 1998).

O fungo A. nidulans apresenta grande capacidade de crescer em um amplo espectro de temperaturas, mas segundo Pontecorvo et al. (1953) as temperaturas ideais estão em torno de $36-37^{\circ} \mathrm{C}$. A temperatura é de grande importância para a conidiogênese, visto que pode ser induzida em culturas submersas para a formação precoce ou tardia de conidióforos (Martinelli, 1976). Diversos mutantes sensíveis à 
temperatura foram descritos (Morris, 1976; Lieber, 1976; Sievers et al., 1999), principalmente mutantes para o ciclo celular e migração nuclear.

As análises realizadas com as linhagens padrões MSE e PPY em temperaturas permissiva $\left(28^{\circ} \mathrm{C}\right)$ e restritiva $\left(42^{\circ} \mathrm{C}\right)$, apresentam atraso na germinação do conídio (formação do tubo germinativo após 4 horas de desenvolvimento) e algumas alterações na distribuição dos septos e ramificações da hifa que também ocorrem tardiamente (Figura 12 a - e, i, j). A linhagem A, em ambas temperaturas também apresenta atraso na germinação e na distribuição dos septos. A ramificação da hifa desta linhagem apresenta maior despolarização em relação ao eixo inicial de germinação um fato interessante é que após o desenvolvimento do primeiro tubo germinativo, um segundo tubo deveria ser emitido em orientação oposta ao primeiro, este processo de desenvolvimento não ocorre na linhagem A no período considerado padrão, pois a hifa inicia a ramificação no primeiro tubo germinativo emitido, e durante o período de 12 horas não foi observada a germinação do segundo tubo germinativo (Figura 11f, o) (Pontecorvo et al., 1953; Morris et al., 1995). Estas alterações na linhagem A podem ocorrer devido à duplicação cromossômica, como analisado macroscopicamente neste trabalho e descrito por Bonatelli \& Azevedo (1977), Niffinegger e Souza (1979). Microscopicamente, a variação no crescimento micelial, atraso nas temperaturas de $28^{\circ} \mathrm{C}$ e $42^{\circ} \mathrm{C}$ pode ser explicada pelas alterações que ocorrem na formação e polarização do tubo germinativo, provocando redução no desenvolvimento do micélio. 


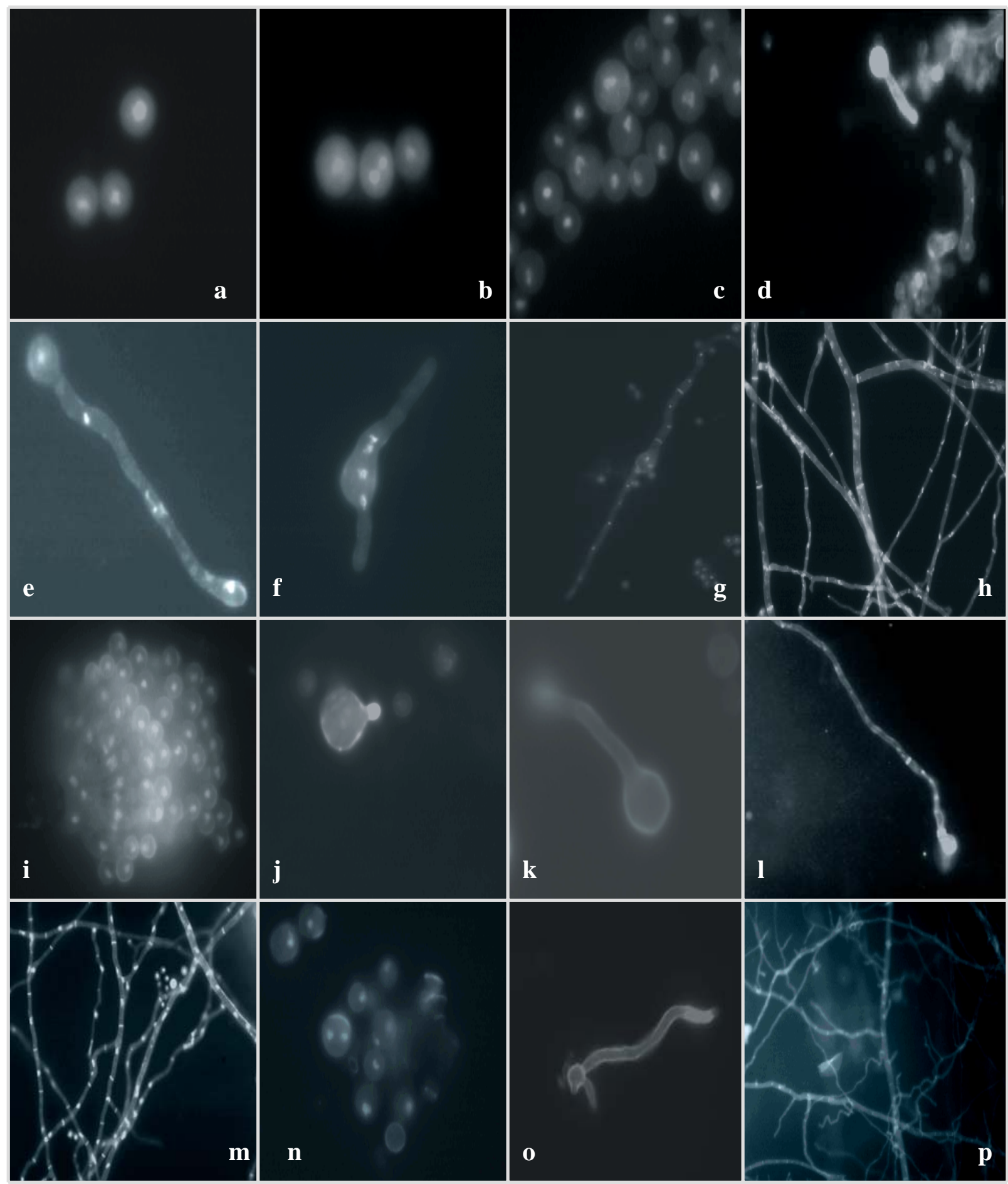

Figura 11 - Germinação dos conídios das linhagens padrões temperatura de $37^{\circ} \mathrm{C}$. Linhagem MSE (a - i) 0, 2, 4, 6, 8, 12, 16, 20 e 32 horas respectivamente. Linhagem A (j - m) 4, 6, 8, 20 horas respectivamente. Linhagem PPY (n p) 2, 16, 20 horas respectivamente. Figuras (a - f, i - k, n - o, aumento de 1000 x; Figuras g, h, 1, m, p, aumento de $400 \mathrm{x}$ 


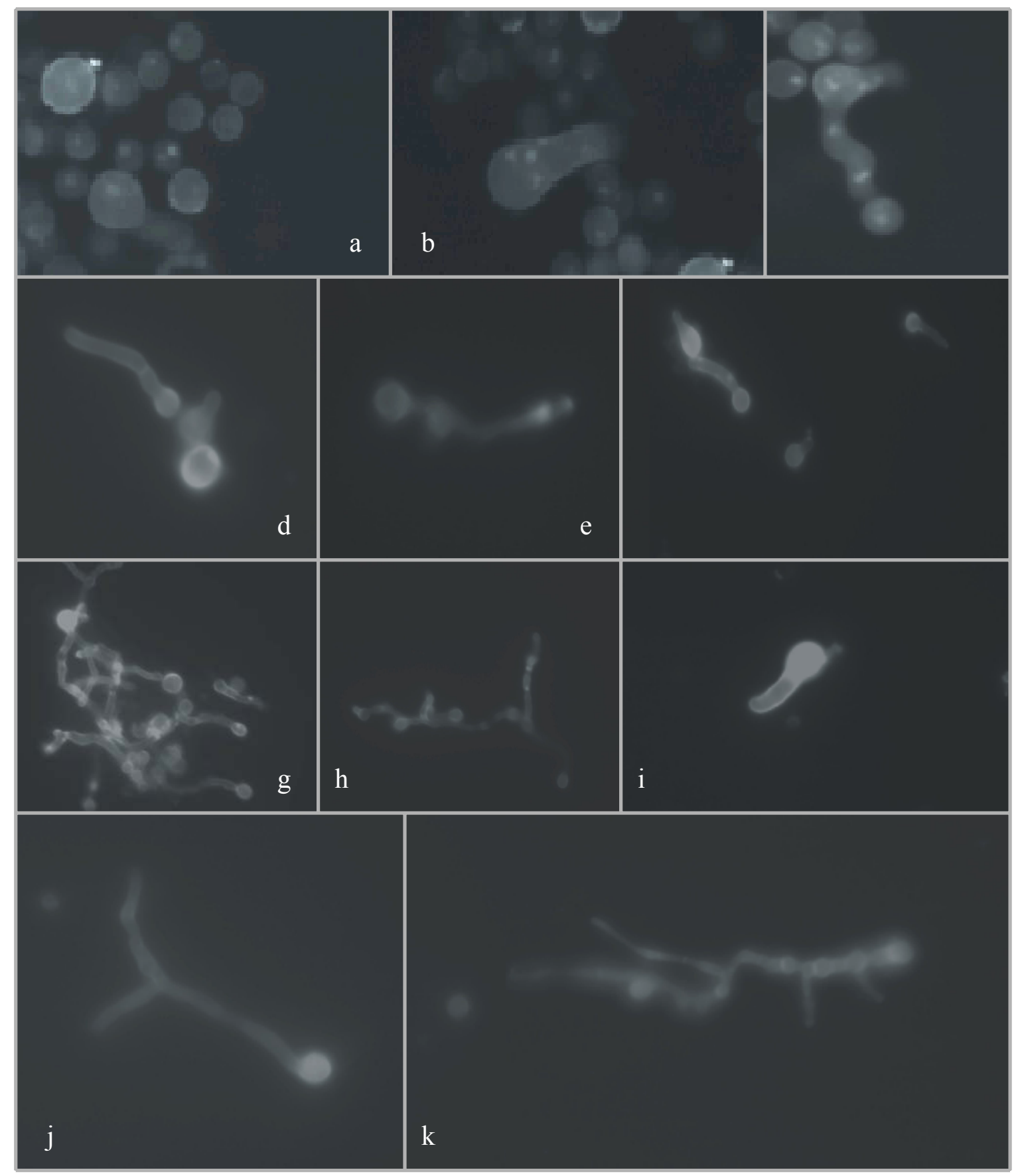

Figura 12 - Germinação dos conídios das linhagens padrões temperatura de $28^{\circ} \mathrm{C}(\mathrm{a}-\mathrm{h})$ e $42^{\circ} \mathrm{C}(\mathrm{i}-\mathrm{k})$. Linhagem MSE (a - c) 4, 8 e 12 horas de desenvolvimento. Linhagem PPY (d - e) 8 e 12 horas. Linhagem A (f - h) 8 e 12 horas, Linhagem MSE (i) 12 horas de desenvolvimento. Linhagem PPY (j) 12 horas. Linhagem A (k) 12 horas. Aumento de 1000 x 


\subsubsection{Análise do Variante Deteriorado V101}

$\mathrm{O}$ variante deteriorado V101, analisado a temperatura de $37^{\circ} \mathrm{C}$, apresentou um pequeno atraso na emissão do tubo germinativo o qual ocorreu em torno de 6 horas, e a emissão do segundo tubo germinativo ocorreu após 16 horas de desenvolvimento, enquanto que o normal seria em torno de 8 - 12 horas. (Figura 13a c). A migração nuclear, aparentemente ocorreu de forma normal. Os septos foram depositados após 8 horas de germinação, e apresentam pequenas anormalidades, isto é, alguns septos delimitam células extremamente longas e outros delimitam células extremamente curtas, mas todas as células apresentam número regular de núcleos (4 - 12 núcleos), outra anormalidade observada está relacionada com a ramificação da hifa, esta não apresentou orientação polarizada, aspecto muito semelhante, observado no mutante rhoA (Guest et al., 2004) (Apêndice) (Figura13 d). O conidióforo do V101, mostrou características anormais, como haste do conidióforo septada e alterações nas estruturas que formam o conidióforo (Giancoli, 2000) (Figura 13e - f).

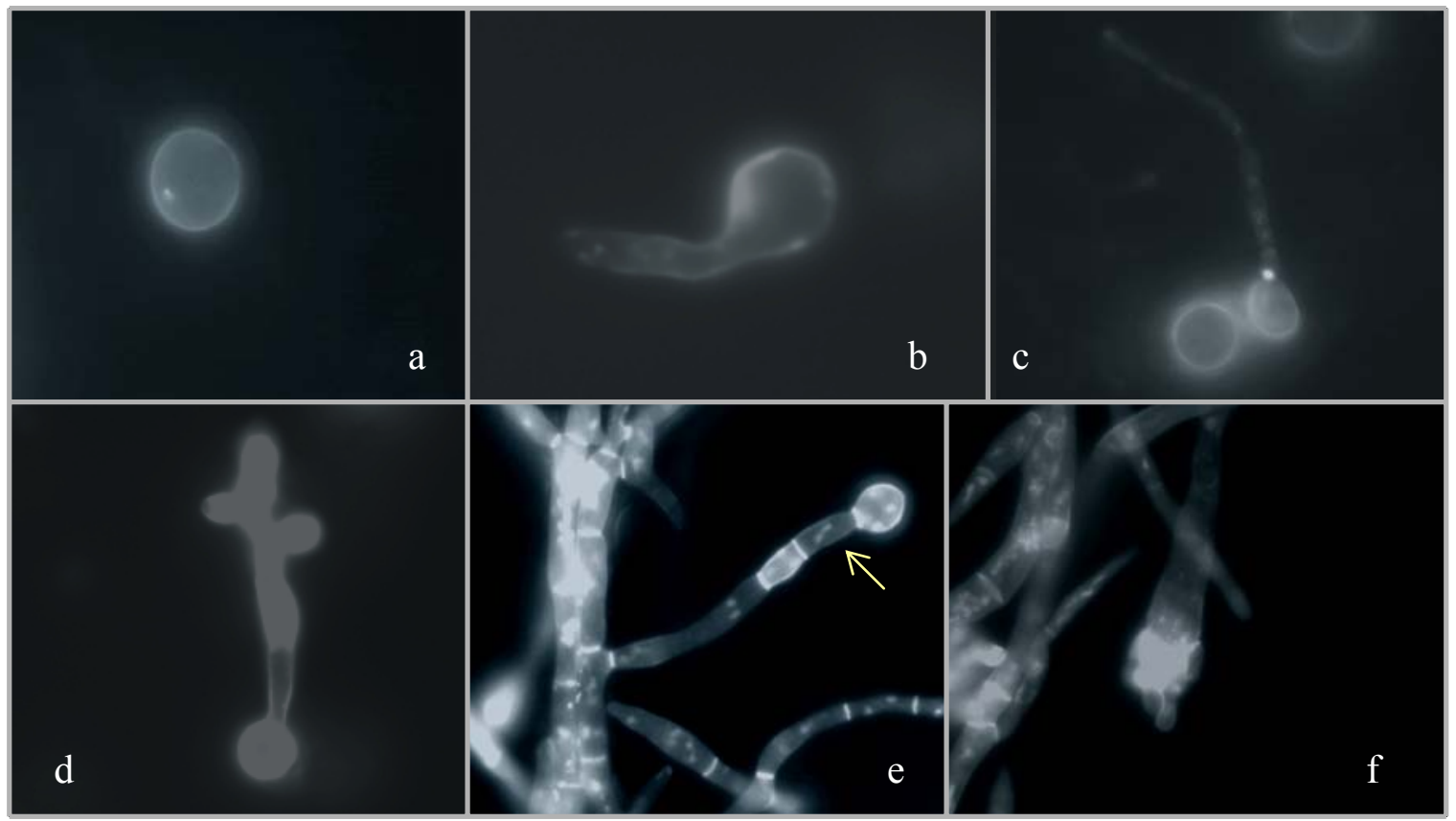

Figura 13 - Variante Deteriorado V101. (a) conídio com o dobro do tamanho 4 horas; (b) conídio com tubo germinativo 8 horas; (c) conídio com extenso tubo germinativo não septado 12 horas; (d) conídio com tubo vegetativo e ramificações anormal não há evidências de septos 16 horas; (e, f) formação de conidióforos anormais 32 horas. Aumento 1000x. A seta indica o final de uma anáfase 
As análises realizadas com V101 nas temperaturas permissiva $\left(28^{\circ} \mathrm{C}\right) \mathrm{e}$ restritiva $\left(42^{\circ} \mathrm{C}\right)$, mostraram atrasos na germinação do conídio (germinação após 4 horas de desenvolvimento) e alterações na distribuição dos septos e ramificações da hifa, esta alterações são muito semelhantes as observadas na linhagem A. (Figura 14).

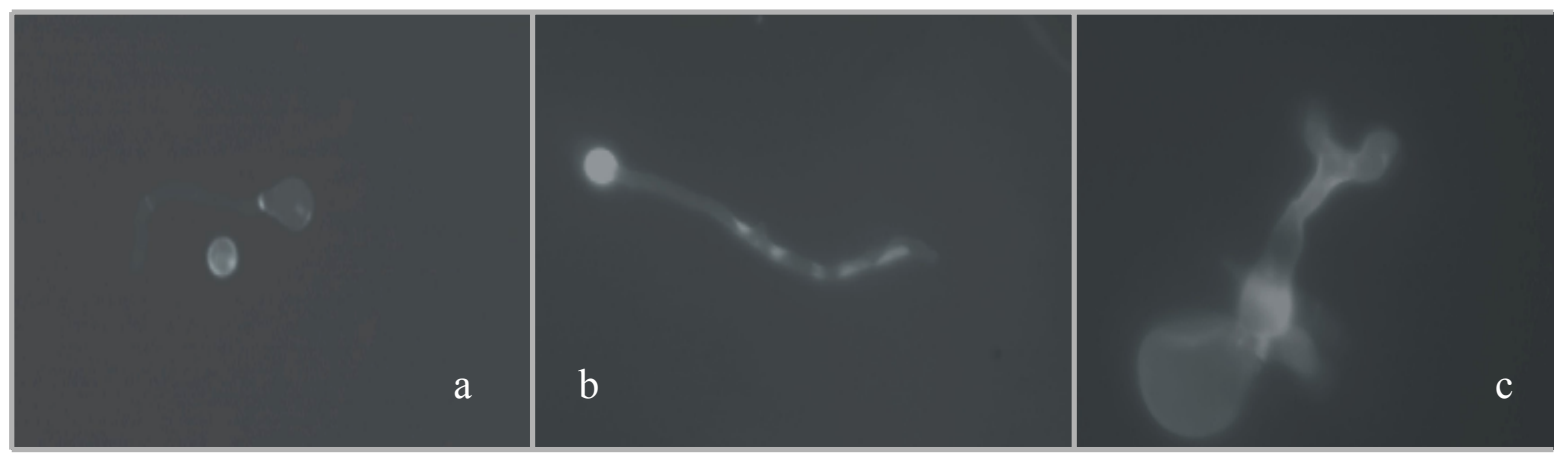

Figura 14 - Variante Deteriorado V101. (a - b) conídios com 6 e 8 horas, temperatura de $28^{\circ} \mathrm{C}$; (c) conídio com tubo germinativo 12 horas, temperatura de $42^{\circ} \mathrm{C}$. Aumento 1000x

\subsubsection{Análise do Variante Deteriorado V102}

$\mathrm{O}$ variante deteriorado $\mathrm{V} 102$, analisado na temperatura de $37^{\circ} \mathrm{C}$, apresentou características muito semelhantes ao V101. Ocorreram pequenos atrasos no seu desenvolvimento, como a formação do tubo germinativo por volta de 4 horas de desenvolvimento (Figura 15a-d). A migração nuclear, aparentemente ocorreu de forma normal. Os septos foram depositados após 8 horas de desenvolvimento, e apresentaram distribuição característica. Com 8 horas de desenvolvimento foram encontradas muitas células "Hülle". As células "Hülle" (células guardas do cleistotécio) são consideradas o primeiro sinal de que o ciclo sexual está se iniciando, estas células são globosas e conectadas ao micélio vegetativo por meio de hifas, suas funções não são muito bem conhecida, mas estão envolvidas na produção de lacase II, um pigmento do conídio e cleistotécio e na proteção do cleistotécio na sua fase inicial de formação. As células "hülle" deveriam desenvolver-se em meio sólido, após um período de aproximadamente 40 horas (Figura 15 e) (Champe et al., 1994). A presença de células hülle pode ser uma 
evidência que esteja ocorrendo alguma mutação em genes envolvidos no ciclo sexual de A. nidulans.

O conidióforo do V101, apresentou características anormais, como haste do conidióforo septada e alterações nas estruturas que formam o conidióforo, como métula e fiálides alongadas (Giancoli, 2000) (Figura 15f - g).

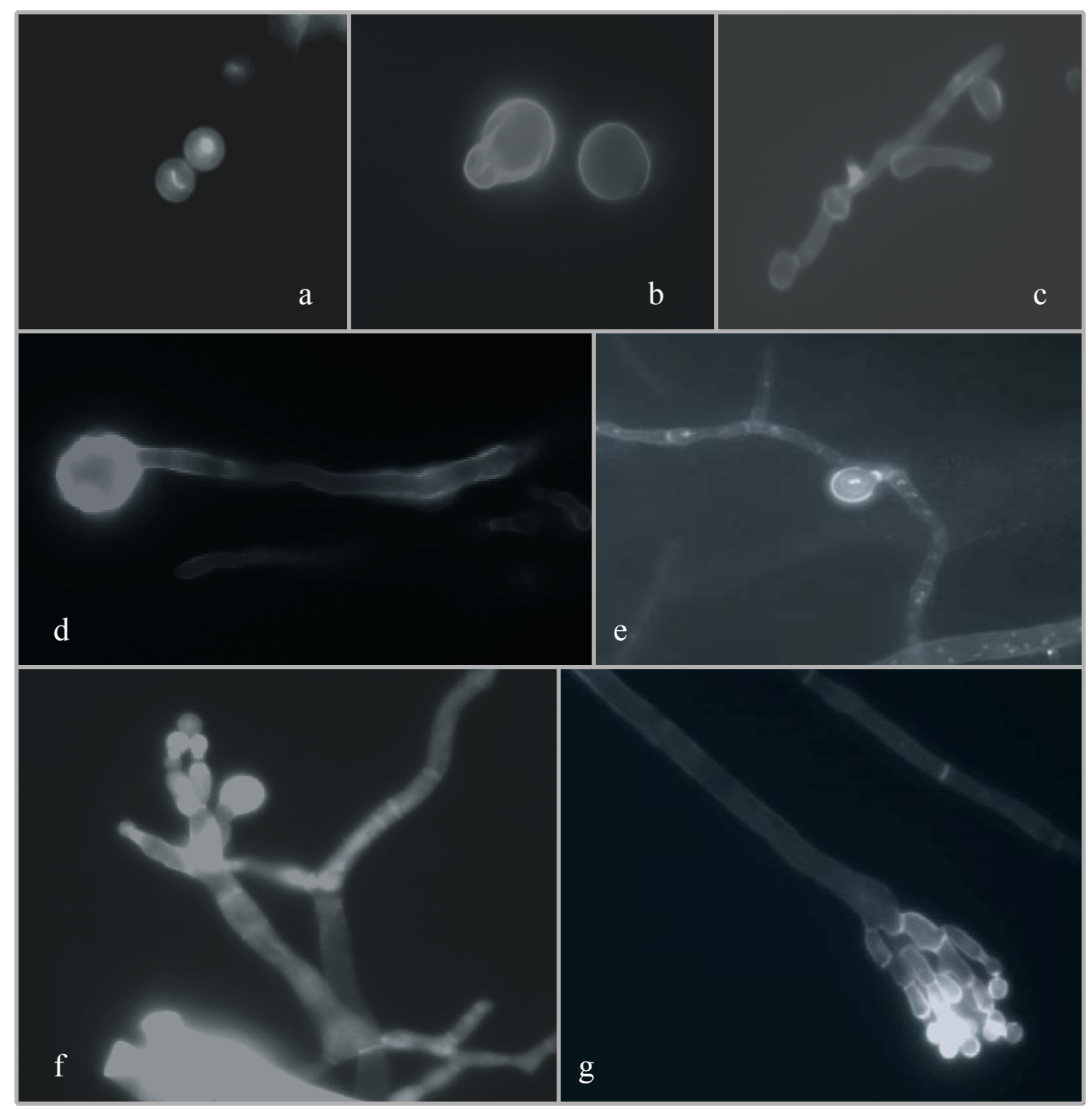

Figura 15 - Variante Deteriorado V102. (a) conídio com 0 hora (b) conídio com inicio da formação do tubo germinativo 4 horas (c) conídio com extenso tubo germinativo 6 horas (d) conídio com tubo vegetativo anormal não há evidências de septos 12 horas; (e) presença de grande quantidade de células hülle, (f, g) formação de conidióforos anormais 32 horas, aumento 1000x 
As análises realizadas com V102 nas temperaturas permissivas $\left(28^{\circ} \mathrm{C}\right) \mathrm{e}$ restritivas $\left(42^{\circ} \mathrm{C}\right)$, mostraram grandes semelhanças com as linhagens A e V101. Ocorrem atrasos na germinação do conídio, e algumas alterações na deposição dos septos e ramificações da hifa. As células hülle continuaram presentes, mas foram observadas em menor quantidades nas duas temperaturas (Figura 16).



Figura 16 - Variante Deteriorado V102. (a - b) conídios com 6 e 8 horas, temperatura de $28^{\circ} \mathrm{C}$; (c) conídio com tubo germinativo 6 horas, temperatura de $42^{\circ} \mathrm{C}$. Aumento 1000x

\subsubsection{Análise do Variante Deteriorado V103}

O Variante deteriorado V103 apresentou atraso no desenvolvimento do tubo germinativo (6 - 8 horas) (Figura 17 b), mas crescimento polarizado das hifas. Em contraste com as linhagens selvagens analisadas, os núcleos do V103 apresentam-se distribuídos de forma irregular ao longo das hifas em formação (Figura 17c), este tipo de irregularidade apresentou semelhança fenotípica com os mutantes bim ("blocked in mitosis") (Morris,1976).

A formação do septo ocorreu tardiamente, além do depósito ao longo da hifa ser irregular, ocasionando distribuição anormal dos núcleos (Figura 17 d), este tipo de irregularidade é muito semelhante os mutantes sep (Harris et al., 1997b; Kaminskyj, 2000).

Os conidióforos observados são anormais, com métulas e fiálides irregulares (Giancoli, 2000). As hastes dos conidióforos são septadas e multinucledas, característica anormal quando comparado com as linhagens padrões (Figura 17e, f). 
As análises realizadas com V103 nas temperaturas permissiva $\left(28^{\circ} \mathrm{C}\right) \mathrm{e}$ restritiva $\left(42^{\circ} \mathrm{C}\right)$, mostraram grandes semelhantes às linhagens $\mathrm{A}, \mathrm{V} 101, \mathrm{~V} 102$, ocorrendo atrasos na germinação dos conídios e alterações na deposição dos septos e ramificações da hifa (Figura 18).

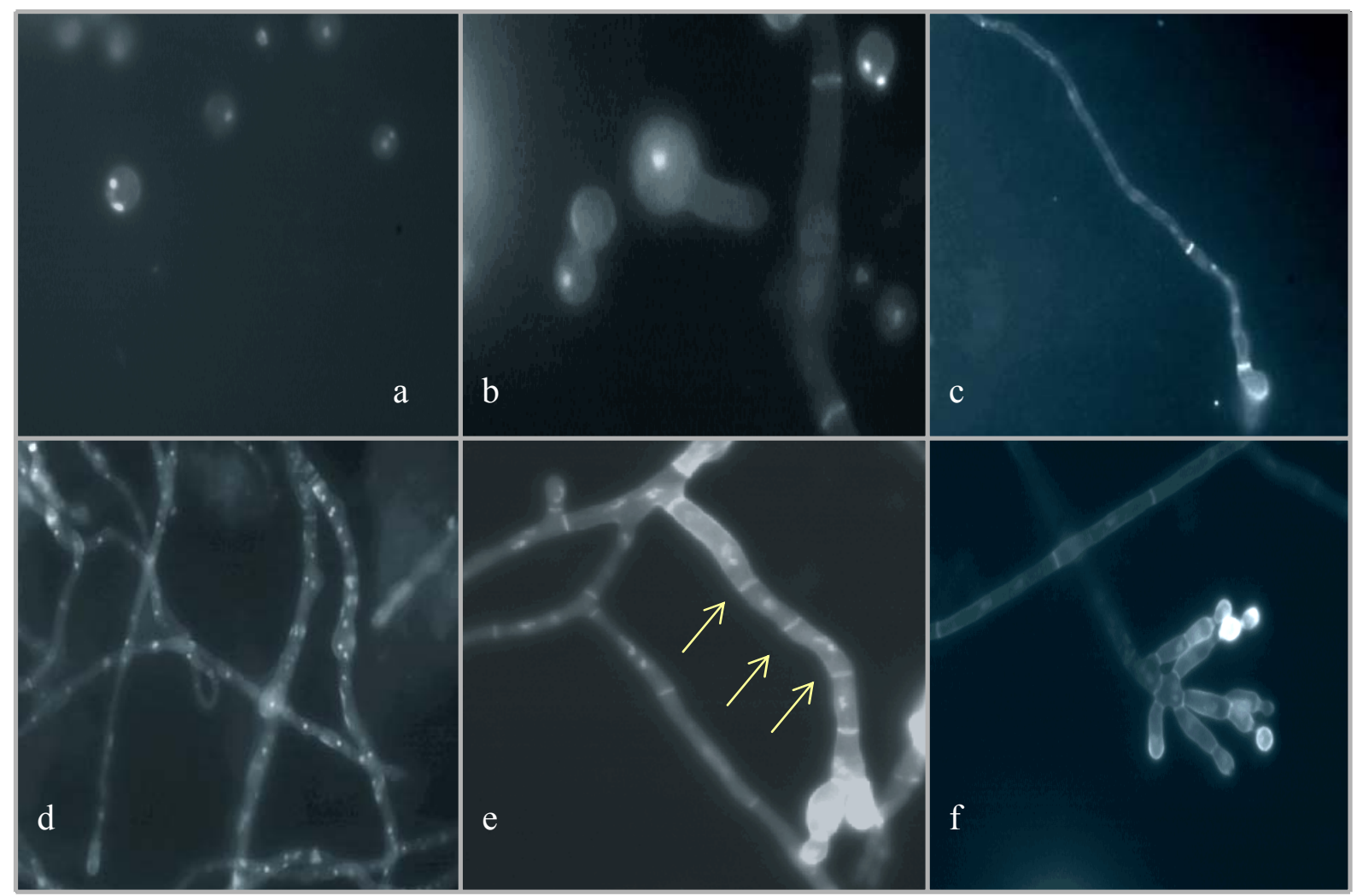

Figura 17 - Variante Deteriorado V103. (a) conídio com 0 hora (b) conídio com inicio da formação do tubo germinativo, 6 horas (c) conídio com extenso tubo germinativo septos com formação irregular, 12 horas (d) formação de hifas ramificadas, 20 horas; (e, f) formação de conidióforos anormais 32 horas, aumento 1000x. As setas indicam a haste do conidióforo septada 


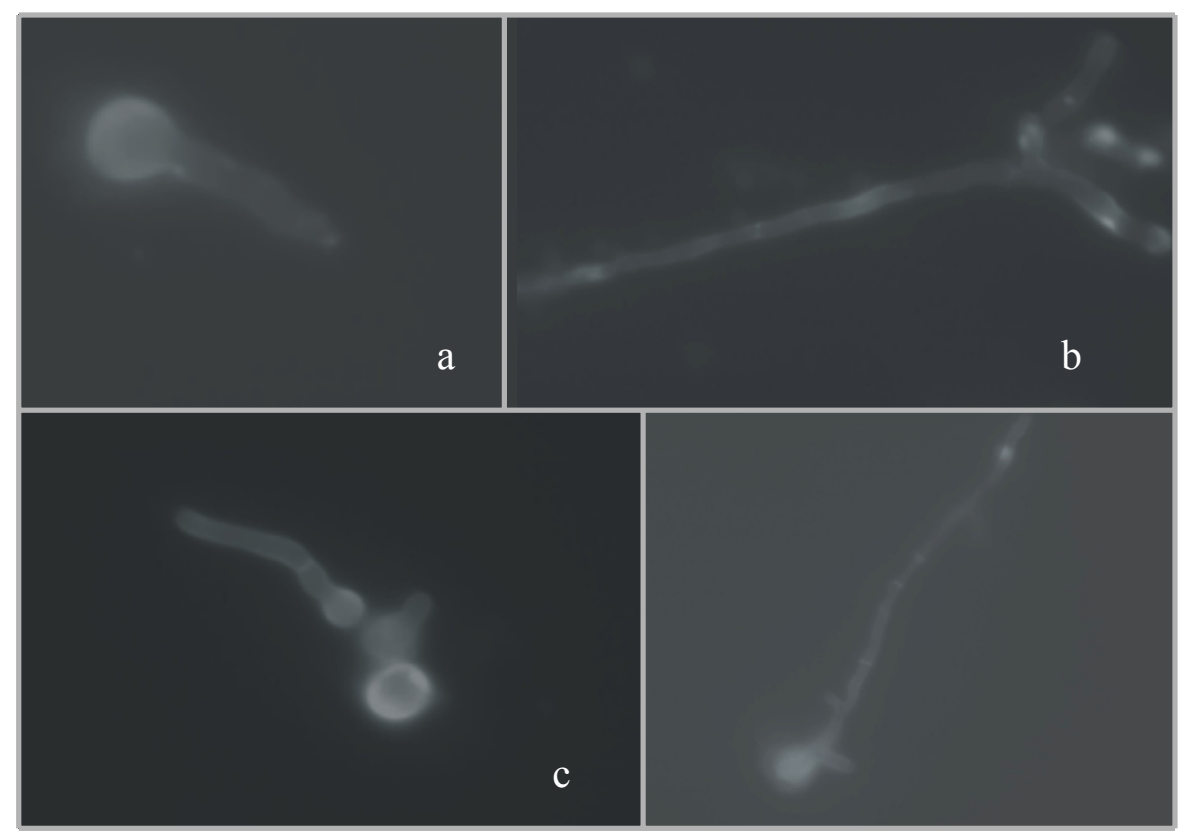

Figura 18 - Variante Deteriorado V103. (a - b) conídios com 6 e 8 horas, temperatura de $28^{\circ} \mathrm{C}$; (c - d) conídio com 6 e 8 horas, temperatura de $42^{\circ} \mathrm{C}$. Aumento $1000 \mathrm{x}$

\subsubsection{Análise do Variante Deteriorado V104}

A análise da microscopia de fluorescência do Variante Deteriorado V104 revelou atraso na germinação dos conídios (Figura 19b, c) assim como atraso na migração nuclear, esta alteração é muito semelhante aos mutantes nud, que estão relacionados com a distribuição nuclear. A mutação nud impede a distribuição correta dos núcleos pelas hifas, este padrão de mutação pode ser observado na Figura 19 (d - f). A anormalidade mais marcante observada no V104, foi relacionada com a formação e distribuição do septo. Os septos apresentam atraso na formação, sendo que estes se formam a partir de 12 horas de germinação (Figura 19d, e, f) e apresentam distribuição irregular. Estas irregularidades são semelhantes às observadas no mutante temossensível sep ("septation deficient") (Morris,1976), que não são capazes de crescer além da terceira divisão nuclear e o seu desenvolvimento fica estagnando logo em seguida durante o período da citocinese; No variante deteriorado V104 as divisões nucleares continuam, assim como o crescimento polarizado, podendo assim ser caracterizado como um tipo de mutante sep 
brando (Harris \& Kraus, 1998). Em relação à formação dos conidióforos, os esterígmas apresentam anormalidades características, como número reduzido e alongamento de métulas (Giancoli, 2000).

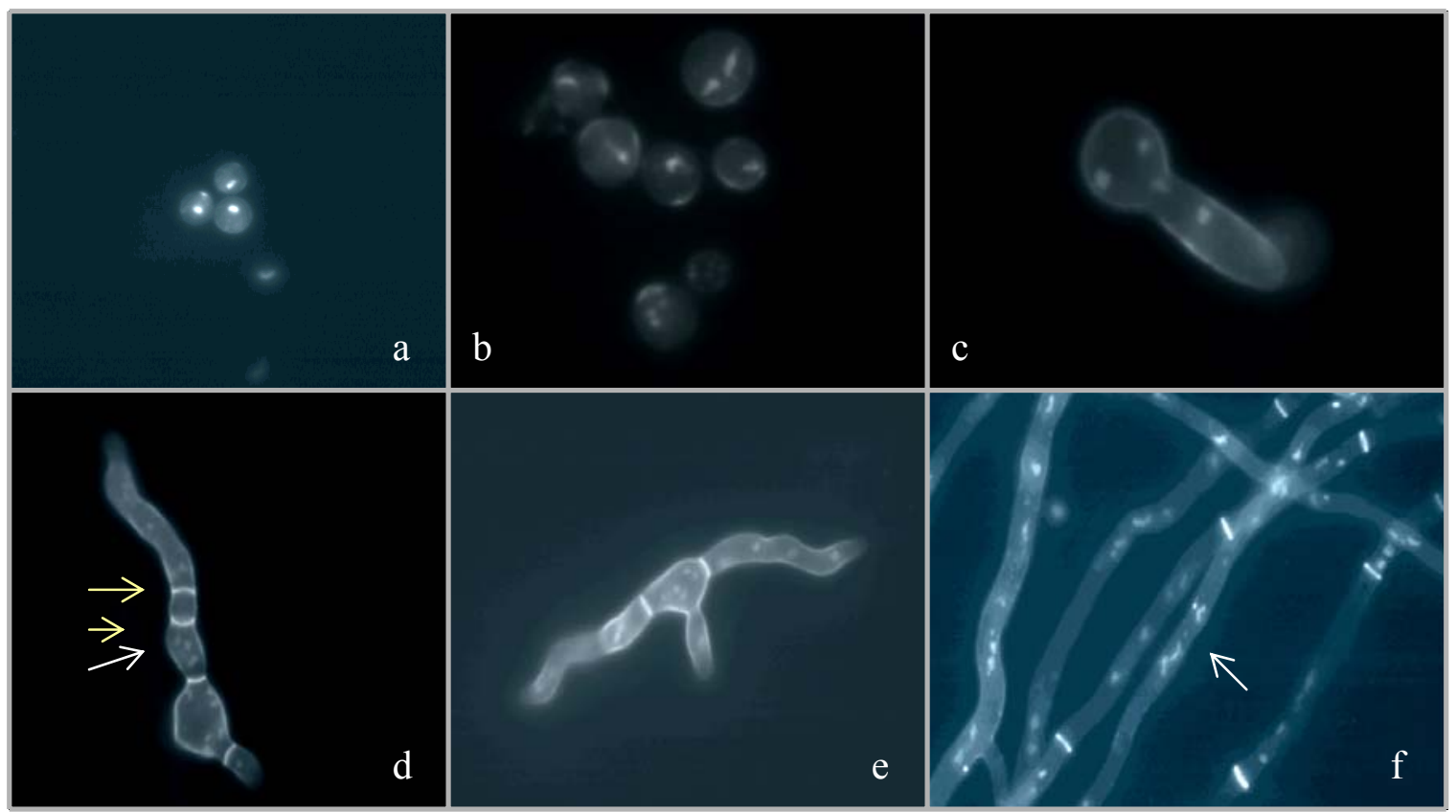

Figura 19 - Variante Deteriorado V104. (a) conídio com 0 hora (b) conídios com o dobro do volume celular, 4 horas (c) conídio com tubo germinativo, 6 horas (d) conídios com tubo germinativo e septação irregular, 12 horas; (e) conídios com tubo germinativo e septação irregular, 16 horas; f) formação do micélio com septação anormal, 20 horas, aumento 1000x. As setas brancas indicam distribuição anormal dos núcleos dentro das hifas; as setas amarelas indicam as alterações na formação de deposição dos septos 
As análises realizadas com V104 nas temperaturas permissiva $\left(28^{\circ} \mathrm{C}\right) \mathrm{e}$ restritiva $\left(42^{\circ} \mathrm{C}\right)$, mostraram grande semelhança a temperatura de $37{ }^{\circ} \mathrm{C}$, ocorrendo atrasos na germinação do conídio, e algumas alterações na deposição dos septos e ramificações da hifa (Figura 20).

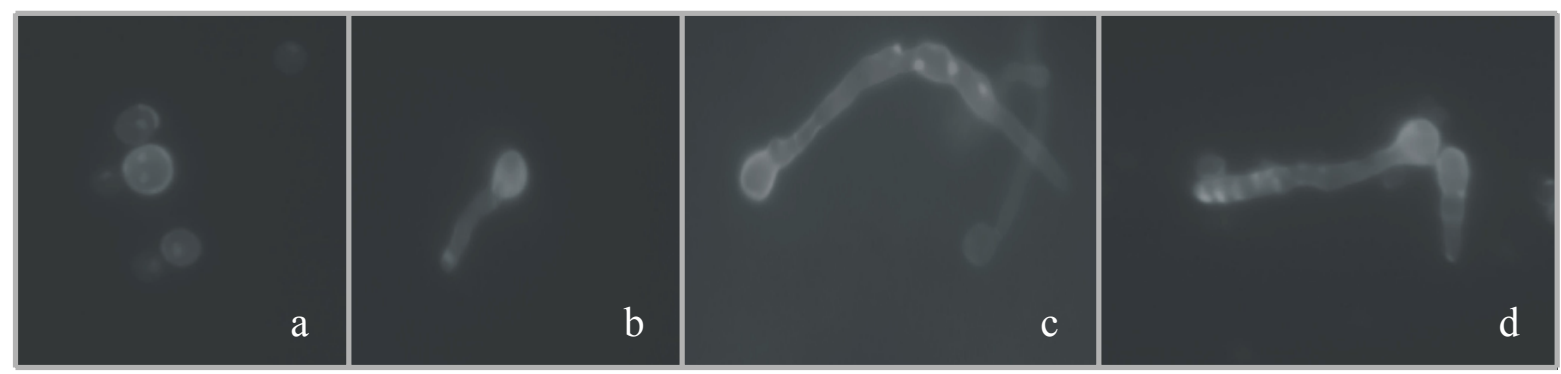

Figura 20 - Variante Deteriorado V104. (a - b) conídios com 4 e 8 horas, temperatura de $28^{\circ} \mathrm{C}$; (c - d) conídio com 12 horas, temperatura de $42^{\circ} \mathrm{C}$. Aumento $1000 \mathrm{x}$

\subsubsection{Análise do Variante Deteriorado V5}

As análises da germinação dos conídios da linhagem V5 na fase inicial são semelhantes às outras linhagens com duplicação cromossômica analisadas (A, V101, V102, V103 e V104), comopodem ser observados na Figura 21. Na temperatura de $37^{\circ} \mathrm{C}$, o variante deteriorado V5 apresenta germinação e desenvolvimento tardio, quando comparado com as linhagens padrões MSE e PPY, a germinação do conídio ocorre após 2 horas de desenvolvimento e o primórdio do tubo germinativo, surge após 4 horas (Figura $21 \mathrm{a}-\mathrm{c}$ ). Com 8 horas de desenvolvimento o tubo germinativo torna-se alongado e com septos, neste período podemos observar a formação do segundo tubo germinativo, sendo emitido em orientação oposta ao primeiro (Figura 21 d). Com 12 horas de desenvolvimento alguns segmentos das hifas sofrem um espessamento da parede celular, além de iniciar a ramificação da hifa (Figura 21 e). Com 20 horas de desenvolvimento o micélio apresenta segmentos de hifas com formação globosa (Figura 21f - h), que contem de 2 a 4 núcleos e estão dispersas por todo micélio do fungo. No último período estabelecido, 32 horas, observaram-se conidióforos anormais (morfologia semelhante a bristle brando) (Clutterbuck, 1969). Alguns conidióforos apresentavam a haste segmentada e em alguns casos ocorreu uma diferenciação em um dos segmentos da haste, formando 
uma estrutura globosa (característica do micélio), este tipo de alteração micelial, hifas globosas intercaladas com hifas normais apresentam muita semelhança aos mutantes com alterações ao nível de parede celular (Bull, 1970; Biagi, 1977; Niffinegger e Souza, 1979), mas estas alterações nunca foram descritas no desenvolvimento do conidióforo, precisamente na haste (Figura 21i).

As análises realizadas com V5 nas temperaturas permissivas $\left(28^{\circ} \mathrm{C}\right) \mathrm{e}$ restritivas $\left(42^{\circ} \mathrm{C}\right)$, mostraram grande semelhança com a temperatura de $37^{\circ} \mathrm{C}$, ocorrendo atrasos na germinação do conídio e algumas alterações na deposição dos septos e ramificações da hifa (Figura 22). Com 12 horas de desenvolvimento foi possível observar a formação das hifas globosas que aparecem abundantemente nas três temperaturas analisadas. (Figura $22 \mathrm{c}$ ). $\mathrm{Na}$ temperatura de $28^{\circ} \mathrm{C}$, pode-se observar irregularidades na distribuição nuclear semelhantes aos mutantes bim. 


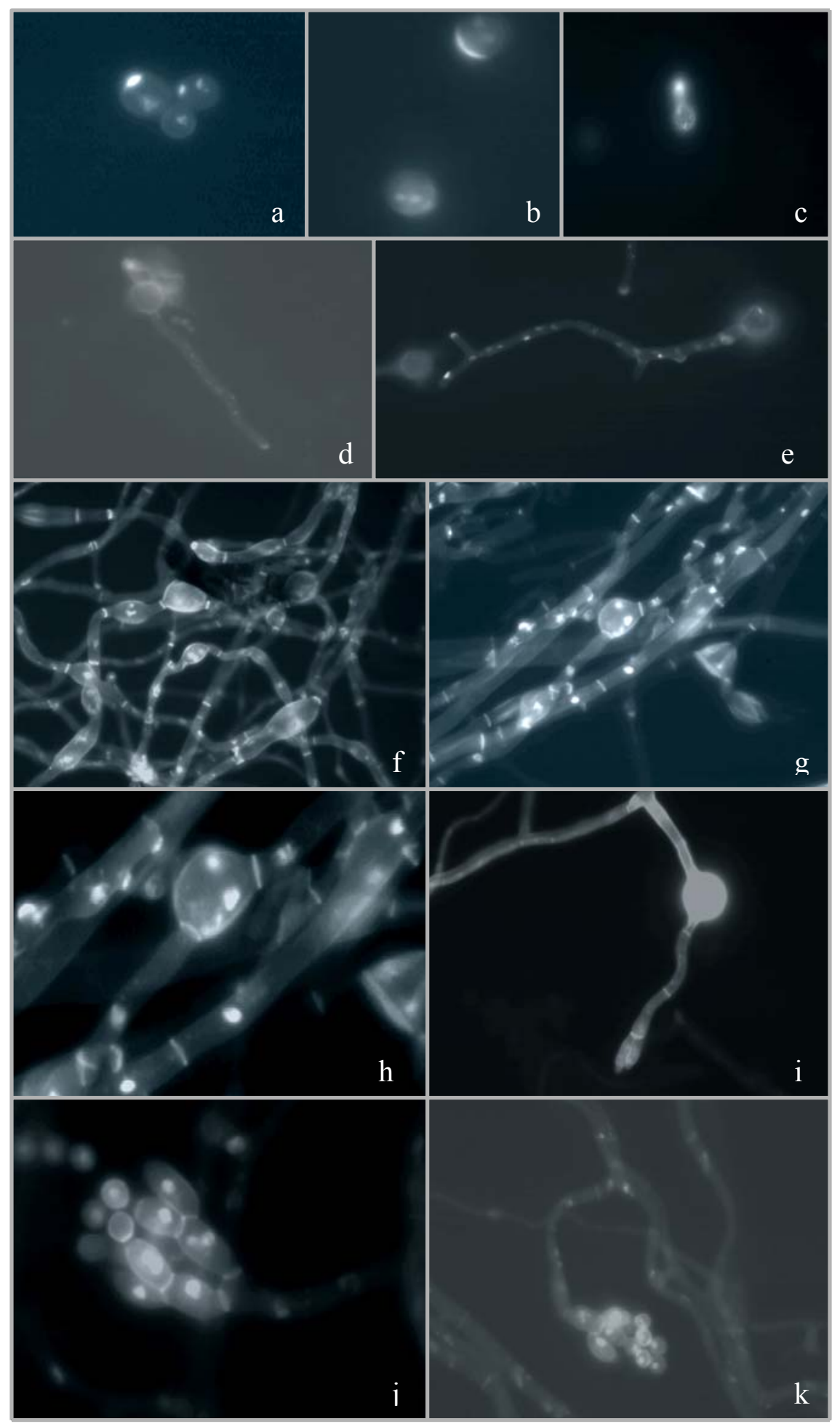

Figura 21 - Variante Deteriorado V5. (a) conídio com 2 horas (b) conídios com o dobro do volume celular, 4 horas (c) conídio com tubo germinativo, 6 horas (d - e) conídios com tubo germinativo e ramificações, 8 - 12 horas; (f - h) hifas globosas, 20 horas; (i) haste do conidióforo segmentada e com estrutura globosa, 20 horas; $(\mathrm{j}-\mathrm{k}$ ) conidióforos anormais. Aumento 1000x 


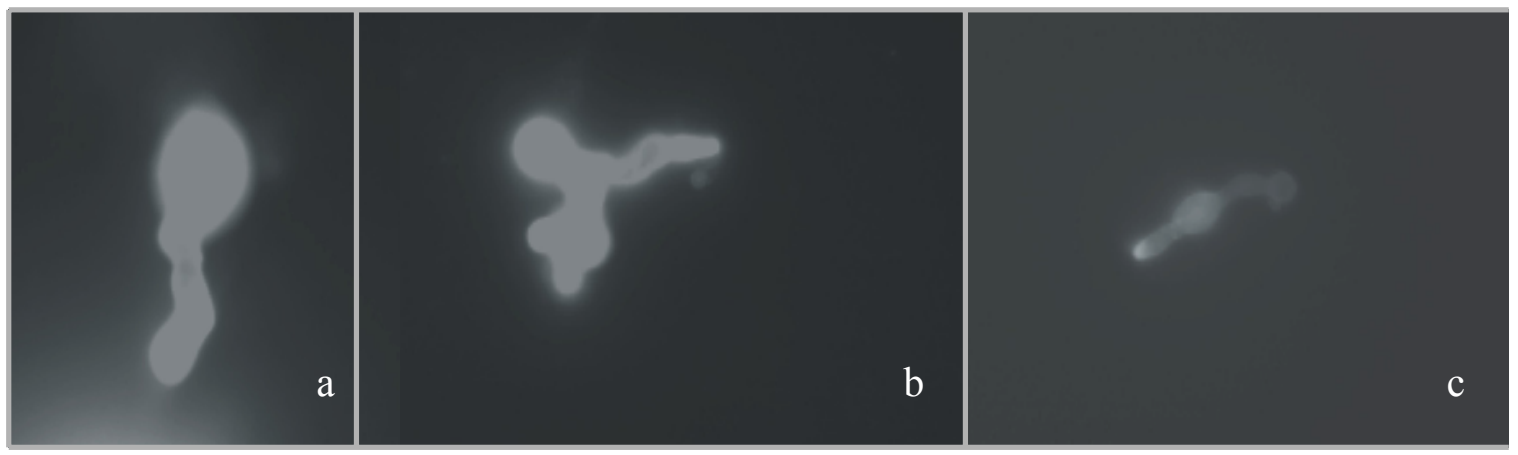

Figura 22 - Variante Deteriorado V5. (a - b) conídios com 8 e 12 horas, temperatura de $28^{\circ} \mathrm{C}$; (c) conídio com 12 horas, temperatura de $42^{\circ} \mathrm{C}$. Aumento $1000 \mathrm{x}$

Estas mutações no desenvolvimento e crescimento, particularmente a formação de hifas globosas, podem estar relacionadas com alterações de proteínas do tipo fosfatase. Kosmidou et al., (2001) descreveram que alterações no gene pphA, responsável pela síntese de um tipo de proteína, a $2 \mathrm{~A}$ fosfatase, que atua na síntese de parede celular e desenvolvimento da hifa, estaria ocasionando crescimento anormal no micélio com: atraso na emissão do tubo germinativo e alterações mitóticas em baixas temperaturas. Outro mutante que apresenta hifas globosas (mas estas são encontradas apenas nas extremidades do micélio) é o phsB4. Este gene é responsável pela estabilização do crescimento em ambientes com pHs variados (ambos pHs, ácidos e/ou alcalinos), mutações neste gene, ocasionam alterações na germinação e desenvolvimento do micélio, além de provocar um atraso no processo mitótico. Nestes mutantes, phsB4, Cuadros et al., (2001) observaram que o desenvolvimento em meio completo líquido leva a lise do micélio e em alguns casos a formação de protoplastos, e que em meio completo sólido ocorria o desenvolvimento anormal de hifa globosas, mas com o desenvolvimento normal do conidióforo. Wilson et al. (2004) demonstraram que outras proteínas também podem ser responsáveis pela produção de hifas globosas, como o ácido $\Delta 9$ - esteárico. $\mathrm{O}$ ácido $\Delta 9$ - esteárico é um importantes constituintes da membrana celular, sendo requerido para o desenvolvimento normal de A. nidulans. Alterações no gene sdeA, leva mutações na formação deste ácido, ocasionando alterações no desenvolvimento e crescimento micelial. 
O variante deteriorado V5 poderia apresentar alguma alteração ao nível de parede celular, como as descritas acima. Para elucidar este evento são necessários mais estudos, principalmente a nível molecular, como o isolamento do determinante de deterioração ou segmento de inserção. Como foi discutido anteriormente, na análise genética, houve dúvidas em relação à correta localização do determinante de deterioração deste variante deteriorado (cromossomo I, IV ou VIII). Podemos supor que neste caso o determinante de deterioração seja um elemento de transposição e que poderia estar distribuído com múltiplas cópias pelo genoma de V5, fato que explicaria as diferenças encontradas nas Análises Genéticas e as diversas alterações encontradas morfologicamente.

Interessante també, observado durante as análises genéticas foi que, apenas no variante deteriorado V5 as hifas globosas eram observadas, nos diplóides (resultantes do cruzamento com V5 e MSE; V5 e G125; V5 e G0248) as hifas apresentaram-se normais. Os setores haplóides obtidos do cruzamento V5 com G0248 apresentavam setores haplóides com hifas normais e setores haplóides com hifas globosas. Esse fato poderia indicar efeito pleiotrópico de gene recessivo.

Foi realizada a contagem do número de núcleos nos segmentos hifais das linhagens MSE, PPY, A e V5, nas diferentes temperaturas $\left(28^{\circ} \mathrm{C}, 37^{\circ} \mathrm{C}\right.$ e $\left.42^{\circ} \mathrm{C}\right)$. Os dados encontram-se na Figura 23. A variação no número de núcleos entre hifas normais e hifas globosas é evidente. Pode-se sugerir que esta diferença esteja relacionada com o volume citoplasmático das hifas, menor volume das hifas globosas em relação às hifas normais e ainda, alterações no processo de migração nuclear.

A quantidade de núcleos por segmento hifal, nas três temperaturas analisadas, variou muito pouco entre as linhagens MSE, PPY e A, demonstrando que a duplicação cromossômica (linhagem A) aparentemente não interfere na distribuição nuclear. O mesmo ocorreu com o variante deteriorado V5, que manteve a média de 3 núcleos por hifa globosa nas três temperaturas analisadas. 


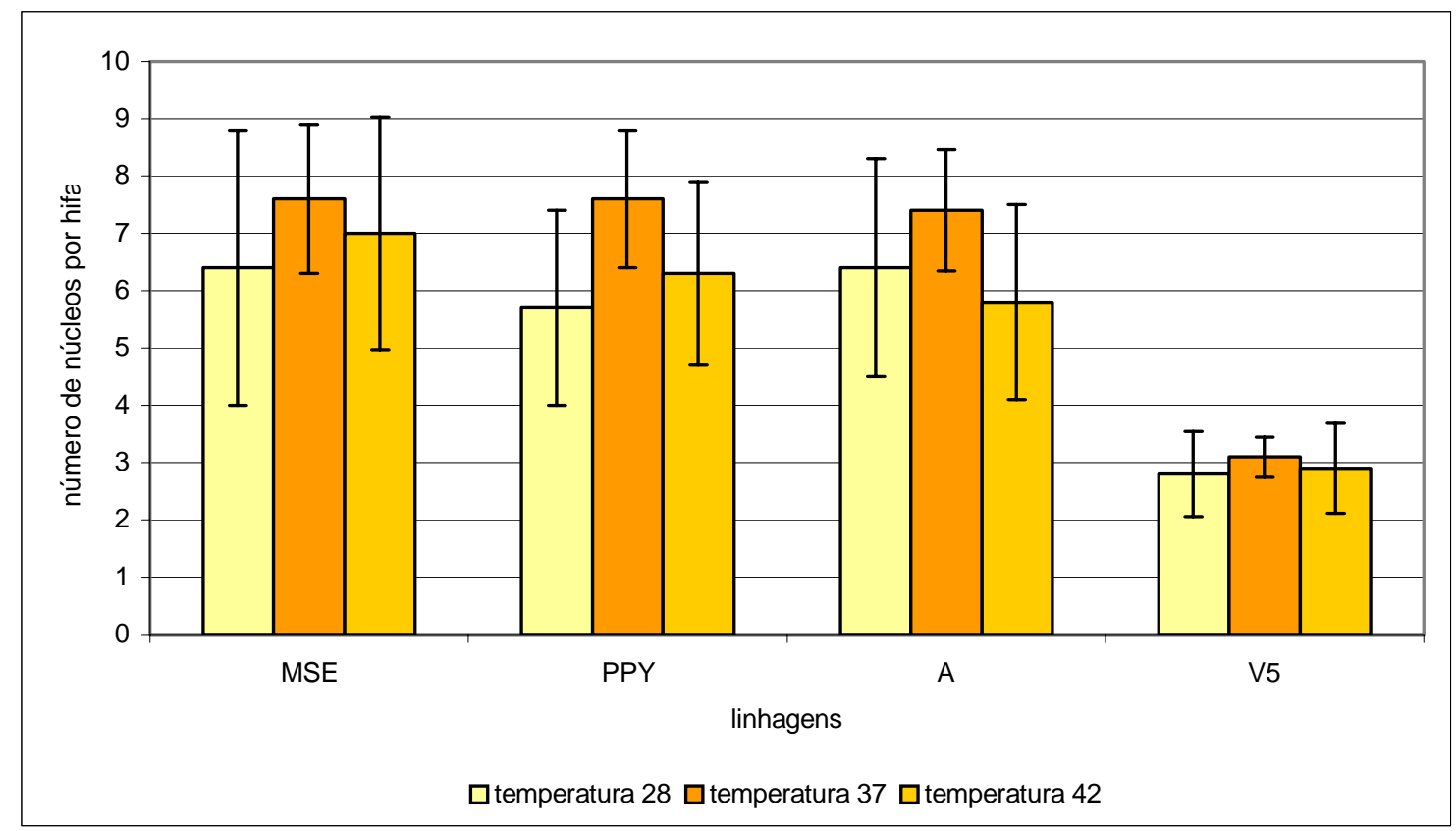

Figura 23 - Número de núcleos nos segmentos hifais nas temperaturas de $28^{\circ} \mathrm{C}, 37^{\circ} \mathrm{C}$ e $42^{\circ} \mathrm{C}$ das linhagens MSE, PPY, A e V5

De uma forma geral, as informações apresentadas durante o estudo da germinação e desenvolvimento da linhagem A (duplicação cromossômica) e dos variantes deteriorados foram muito semelhantes. Na linhagem $\mathrm{A}$ e todos variantes deteriorados foi observado um atraso temporal na germinação (emissão do tubo germinativo) e desenvolvimento da hifa, alterações no padrão de distribuição dos septos e alterações na polaridade e ramificação das hifas. Estas alterações lembram alguns mutantes descritos na literatura, como o mutante sep (Harris et al., 1997a, b), envolvido no processo de citocinese, o mutante pod responsável pela polaridade da hifa (Harris et al. 1999a, b) e o mutante rho (Guest et al., 2004) responsável pela ramificação e síntese da parede celular. Além destas alterações no início do desenvolvimento ocorrem alterações nos conidióforos como, hastes ramificadas e métula e fiálides alongadas.

Estas informações mostram, que as alterações no padrão de desenvolvimento de A. nidulans, ocorre deste a germinação, início do ciclo celular até o desenvolvimento do conidióforo, portanto dever estar ocorrendo uma interação entre 
genes do ciclo e progressão celular com genes do desenvolvimento do conidióforo (Ye, et al., 1999; Schier et al., 2001). Para determinarmos exatamente qual ou quais genes estão envolvidos neste processo, seriam necessárias mais informações de natureza gênica sobre os variantes deteriorados. Uma informação muito valiosa é identificar o determinante de deterioração. A hipótese mais aceita, é que o determinante de deterioração seja um elemento de transposição (Azevedo \& Roper, 1970), este fato fica evidenciado pelo comportamento do determinante de deterioração, que salta pelos oito cromossomos de A. nidulans, além das dificuldades de mapear correta e precisamente a localização dos determinantes de deterioração (Azevedo \& Roper, 1970; Menezes, 1974; Niffinegger e Souza, 1979; Paccola, 1982; Monteiro, 1989; Molina, 1993; Pascon, 1994; Queiroz et al., 2000; Giancoli, 2000; Giancoli, 2004).

\subsection{Isolamento de mutantes para a nitrato redutase gene niaD}

Foi utilizada suspensão de conídios da linhagem A de A. nidulans (duplicação cromossômica I $\rightarrow$ II), sendo inoculados $10^{5}$ conídios por $\mathrm{mL}$ de solução tween, em Meio Mínimo com glutamato de potássio e mais clorato de potássio 0,3 M. Deste modo foram isolado mutantes espontâneos resistentes ao clorato de potássio.

Segundo Cove (1976a, b) o clorato é muito mais tóxico às linhagens em determinadas fontes de nitrogênio, sendo assim o número e o tipo de mutante resistente ao clorato são dependentes da fonte de nitrogênio presente no meio de cultura.

Como a resistência ao clorato está associada com a perda da capacidade regulatória das enzimas nitrato redutase, as quais catalisam a redução de nitrato a amônia (Cove, 1979a, b) a classificação dos mutantes resistentes a clorato é baseada nas respostas de crescimentos dos mutantes em diferentes fontes de nitrogênio, tendo como controle uma linhagem selvagem, a qual utiliza todas as fontes de nitrogênio, mas é sensível a clorato, podemos testar os mutantes obtidos. Os mutantes foram testados em meio mínimo com diferentes fontes de nitrogênio, a fim de classificá-los em niaD, cnx, nir, nii, CRUN (Tabela 14). 
Portanto linhagens clorato resistentes apresentam a perda da capacidade regulatória da cadeia enzimática.

$\begin{array}{cccc}\text { Nitrato } & \rightarrow \quad \text { Nitrito } & \rightarrow & \text { Amônia } \\ 1 & & 2 & \end{array}$

1. Enzima nitrato redutase

2. Enzima nitrito redutase

Tabela 14. Assimilações de fontes de nitrogênio (Cove,1979a, b)

\begin{tabular}{ccc}
\hline Mutante & Não cresce & Cresce \\
\hline niaD & Nitrato & Nitrito, amônia, hipoxantina. \\
$c n x$ & Nitrato & Nitrito e amônia \\
nir, nii & Nitrato e nitrito & Amônia e hipoxantina \\
CRUN & Apresenta fraca resistência ao clorato & Cresce em todas fontes de nitrogênio \\
\hline
\end{tabular}

Segundo Cove (1976a, b), os mutantes nir crescem melhor em relação à linhagem selvagem na presença de histidina, leucina e metionina e são menos resistentes, portanto aparecem em menor freqüência que os mutantes niaD e $c n x$, quando estes estão presentes em outras fontes de nitrogênio como acetamina, alanina, arginina, aspartato, glutamato, glicina, leucina, ornitina, treonina, triptofano e valina. Portanto para se isolar mutantes nir é necessário utilizar ácido úrico como fonte de nitrogênio na qual são mais resistentes ou utilizar doses mais elevadas de fontes de nitrogênio. Os mutantes para nitrato redutase podem apresentar crescimento residual na presença de aminoácidos.

Foram inoculadas o total de 250 placas de Petri, a temperatura de $37^{\circ} \mathrm{C}$ por 8 dias em meio mínimo adicionado de glutamato de potássio e clroato de potássio. Foram obtidos 159 mutantes, os quais foram purificados por estrias, e submetidos aos 
testes com diferentes fontes de nitrogênio, para classificar os diferentes tipos de mutantes para nitrato redutase (Tabela 15). As morfologias das colônias obtidas foram: compactas, com micélio aéreo e em alguns casos colônias com micélio apresentando autólise.

Tabela 15. Mutantes para nitrato redutase isolados em diferentes fontes de nitrogênio

\begin{tabular}{cc}
\hline Mutantes & Isolados \\
\hline niaD & 35 \\
cnx & 23 \\
nir, nii & 23 \\
CRUN & 78 \\
\hline Total & 159 \\
\hline
\end{tabular}

Os 35 mutantes niaD isolados, apresentavam pequeno crescimento (residual) em meio mínimo com nitrato de sódio mais clorato de potássio. Este problema ocorreu devido a presença do aminoácido prolina (colocado no meio mínimo de cultura, devido à auxotrofia da linhagem A para as marcas prolina e ácido $\rho$-aminobenzóico), que funciona como uma fonte de nitrogênio para o desenvolvimento inicial dos mutantes niaD. Devido ao crescimento residual apresentado pelos mutantes nia $\mathrm{D}$, este isolamento foi descartado, e um novo tipo de isolamento realizado.

Para eliminar o problema com a marca auxotrófica prolina presente na linhagem A, foi realizado o cruzamento via ciclo sexual (item 3.2.4) da linhagem A com a linhagem MSE (linhagens com marcas complementares).

Este tipo de isolamento foi feito em decorrência do sucesso evolucionário dos genes, o qual é baseado na reprodução (meiose). Os elementos de transposição podem vencer facilmente a segregação imposta pela meiose, e por meio de processos replicativos podem duplicar-se e transpor-se ao longo dos cromossomos, aumentando 
desta forma sua dispersão pelo genoma (Zeyl \& Bell, 1996 e 1997; Zeyl et al., 1996; Rice \& Chippindale, 2001).

Foram selecionados alguns cleistotécios, que foram rompidos em solução tween e diluídos. A suspensão de ascósporos foi inoculada em meio de cultura mínimo contento nitrito de sódio $0,01 \mathrm{M}$ mais clorato de Potássio 0,45 M. A quantidade de clorato de potássio foi aumentada para certificar a obtenção de mutantes.

Foram inoculadas 120 placas de Petri, as quais foram incubadas a $37^{\circ} \mathrm{C}$ por 7 dias. Foram isolados 162 mutantes resistentes ao clorato de potássio e que se desenvolveram em meio mínimo com nitrito de sódio.

Posteriormente foram feitos testes com meio mínimo contendo separadamente nitrato de sódio, amônia e hipoxantina, para selecionar apenas mutantes niaD. Este isolamento foi realizado para que os mutantes obtidos não apresentassem as marcas prolina e ácido $\rho$-aminobenzóico (paba). Após os testes em diferentes meios de cultura, foram selecionados 81 mutantes niaD, apresentando morfologias variadas: colônias compactas; colônia com micélio aéreo; coloração verde, amarela e branca; muitos apresentavam micélio que sofria autólise, crescimento lento a temperatura de $37^{\circ} \mathrm{C}$ e baixa esporulação

Foi realizado o teste de reversão para os 81 mutantes selecionados. Após o teste foram selecionados 23 mutantes niaD, a seleção dos mutantes foi baseada naqueles que apresentassem a maior taxa de reversão, sendo que estes seriam os possíveis candidatos a possuir o segmento de inserção, os mutantes isolados foram denominados de $\mathrm{Sx} 1, \mathrm{Sx} 2, \ldots . ., \mathrm{Sx} 23$. Os resultados do teste de reversão estão na Tabela 16. Após a seleção destes 23 mutantes, foram realizadas a extração de DNA e as análises moleculares. 
Tabela 16. Teste de reversão de mutantes niaD

\begin{tabular}{cccc}
\hline Mutante & $\begin{array}{c}\text { Freqüência de } \\
\text { Reversão }\end{array}$ & Mutante & $\begin{array}{c}\text { Freqüência de } \\
\text { Reversão }\end{array}$ \\
\hline Sx1 & $3,44 \times 10^{-5}$ & Sx13 & $1,5 \times 10^{-5}$ \\
Sx2 & $3,22 \times 10^{-5}$ & Sx14 & $1,9 \times 10^{-5}$ \\
Sx3 & $6,1 \times 10^{-5}$ & Sx15 & $2,11 \times 10^{-5}$ \\
Sx4 & $5,8 \times 10^{-5}$ & Sx16 & $6,4 \times 10^{-5}$ \\
Sx5 & $5,0 \times 10^{-5}$ & Sx17 & $7,3 \times 10^{-6}$ \\
Sx6 & $9,5 \times 10^{-5}$ & Sx18 & $1,6 \times 10^{-4}$ \\
Sx7 & $2,3 \times 10^{-4}$ & Sx19 & $2,0 \times 10^{-5}$ \\
Sx8 & $9,8 \times 10^{-6}$ & Sx20 & $3,074 \times 10^{-5}$ \\
Sx9 & $8,9 \times 10^{-5}$ & Sx21 & $9,68 \times 10^{-4}$ \\
Sx10 & $2,0 \times 10^{-4}$ & $\mathrm{Sx} 22$ & $3,8 \times 10^{-5}$ \\
Sx11 & $8,9 \times 10^{-5}$ & $\mathrm{Sx} 23$ & $3,3 \times 10^{-5}$ \\
Sx12 & $9,59 \times 10^{-5}$ & - & - \\
\hline
\end{tabular}

\subsubsection{Análise Molecular dos Mutantes niaD}

Tendo como objetivo a clonagem do variante de deterioração (Elemento de Transposição) presente na linhagem A de A. nidulans, e responsável pela formação dos setores deteriorados como o V5, V101, V102, V103 e V104, delineou-se uma estratégia para o isolamento e clonagem.

Seguindo os métodos clássicos para clonagem de transposição, teríamos quatro técnicas para utilizarmos: detecção por sondas heterólogas de Transposons; detecção via PCR, utilizando primers específicos para regiões conservadas da transposase e transcriptase reversa; a terceira técnica seria a utilização de biblioteca genômica do fungo, e por meio de hibridizações diferenciais, localizar regiões altamente repetitivas no genoma; e a quarta técnica o "transposon trap", utilizada na grande maioria dos casos, onde os transposon são identificados como seqüências de inserção em 
um gene, como exemplo do gene da nitrato redutase (niaD). Os mutantes niaD são analisados por Southern blot, após ser realizada a digestão enzimática do DNA com enzimas que cortem unicamente o gene da nitrato redutase, emprego da sonda do gene da nitrato redutase para localizar o fragmento do gene niaD que contenha a inserção do elemento de transposição, o qual é subclonado e seqüenciado.

Inicialmente utilizou-se a técnica do "transposon trap", isolando mutantes niaD, obtidos da linhagem A (item 4.3). Os mutantes isolados foram analisados primeiramente via $\mathrm{PCR}$, com primers específicos do gene niaD (construídos especificamente para este trabalho). O objetivo desta análise foi verificar se o produto de amplificação apresentaria um tamanho maior do que o esperado, confirmando a presença do fragmento de inserção. Posteriormente utilizou-se os mutantes niaD obtidos e os variantes deteriorados V5, V101, V102, V103 e V104, com outros primers específicos, para transposase, transcriptase reversa e transposon MATE (Tabela 4, item 3.5.4). A técnica de Southern blot não foi utilizada devido a motivos técnicos.

\subsubsection{Análise Molecular com primers niaD}

Foram construídos cinco primers do gene niaD, baseado nas seqüência M58291.6 do GeneBank, e que foram planejadas e construídas de forma a estudar e verificar toda a extensão do gene niaD (Figura 24). Os primers niaDF2 e niaDR4 localizam-se dentro da região conservada "oxidoreductase molybdopterin binding domain (oxidored molyb)" e o primer niaDCDSR localiza-se na região conservada "ferric reductase like transmembrane component (NAD binding)" (Figura 25), a construção destes primers em regiões conservadas aumentam as chances de serem amplificados, além de poderem ser utilizados para outras espécies de Aspergillus, como primers específicos para genes conservados (Glass \& Donaldson, 1995).

Os resultados provenientes das PCR não indicaram nenhum fragmento de inserção inserido no gene niaD. (Figuras 26, 27, 28). 
3'

Gene niaD - 3618

NiaDF2 - niaDR4 - 670 pb

NiaDF2 - niaDR2 - 1275 pb

NiaDCDSF - niaDCDSR - 2986 pb

Figura 24 - Esquema da localização dos primers dentro do gene niaD (seqüências de ácidos nucléicos)

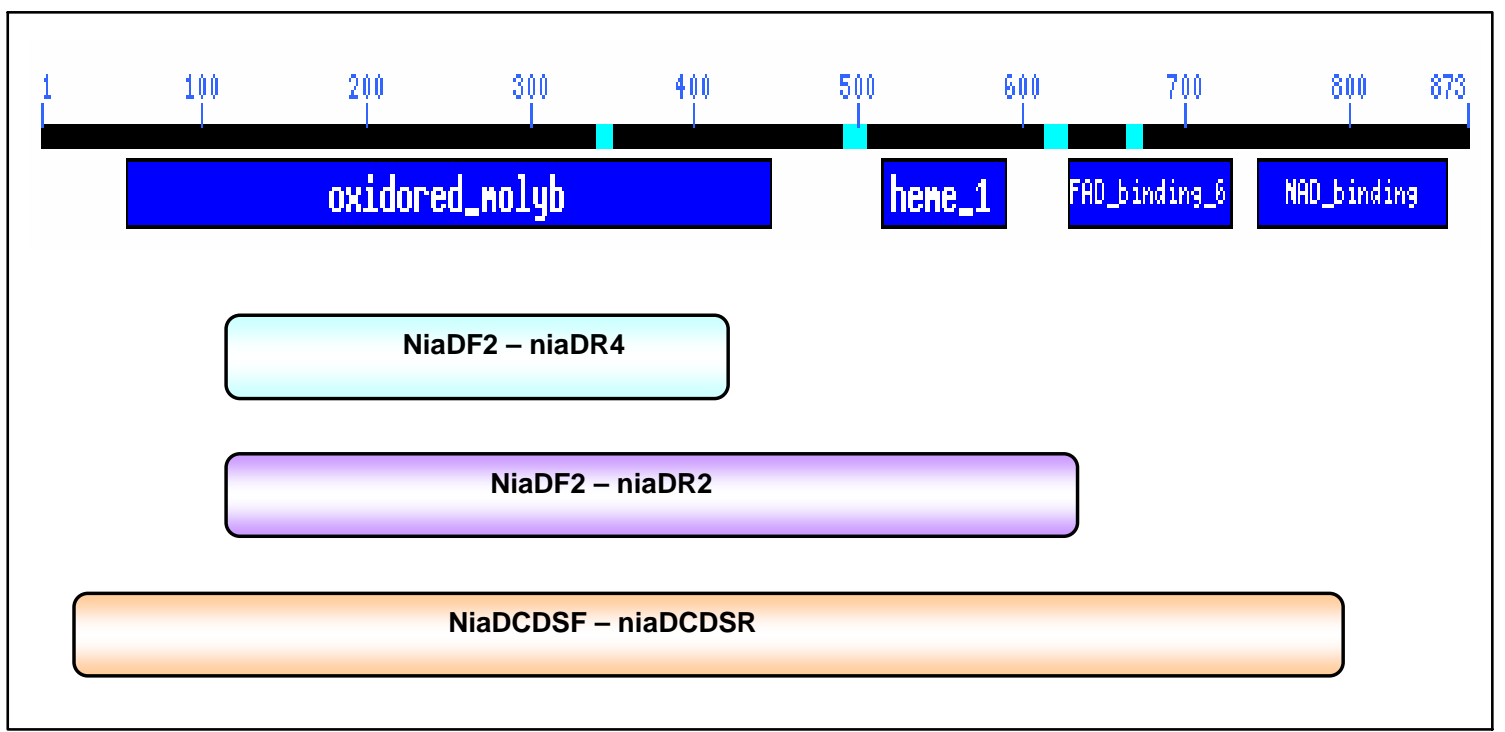

Figura 25 - Esquema da localização dos primers dentro da seqüência de aminoácidos do gene niaD 


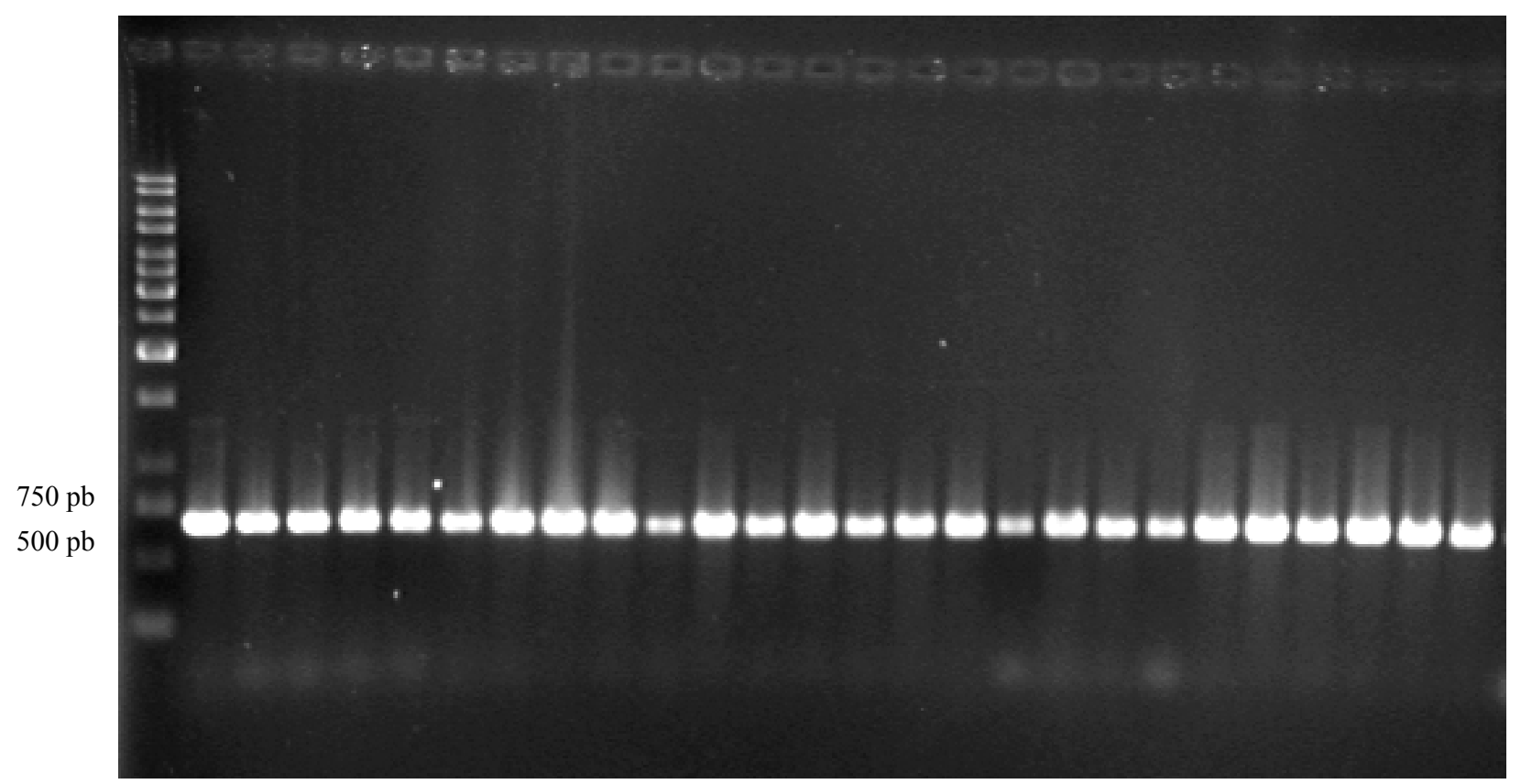

Figura 26 - Primers niaDF2 - niaDR4. (1) marcador $1 \mathrm{~Kb}$, (2) MSE, (3) A, (4) G125, (5) Sx1, (6) Sx2, (7) Sx3, (8) Sx4, (9) Sx5, (10) Sx6, (11) Sx7, (12) Sx8, (13) Sx9, (14) Sx10, (15) Sx11, (16) Sx12, (17) Sx13, (18) Sx14, (19) Sx15, (20) Sx16, (21) Sx17, (22) Sx18, (23) Sx19, (24) Sx20, (25) Sx21, (26) Sx22, (27) Sx23

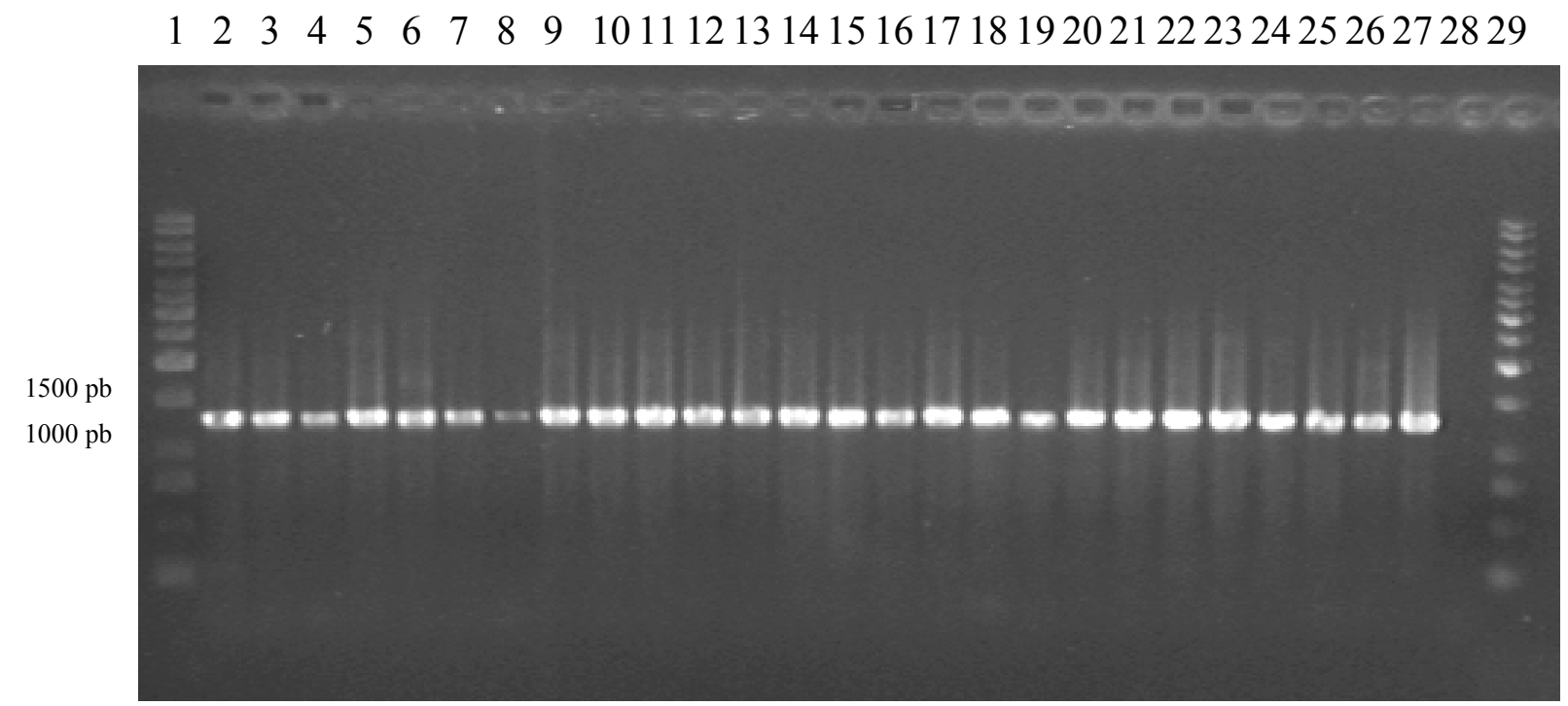

Figura 27 - Primers niadF2 - niaDR2. (1) marcador $1 \mathrm{~Kb}$, (2) MSE, (3) A, (4) G125, (5) Sx1, (6) $\mathrm{Sx}$, (7) Sx3, (8) Sx4, (9) Sx5, (10) Sx6, (11) Sx7, (12) Sx8, (13) Sx9, (14) Sx10, (15) Sx11, (16) Sx12, (17) Sx13, (18) Sx14, (19) Sx15, (20) Sx16, (21) Sx17, (22) Sx18, (23) Sx19, (24) Sx20, (25) Sx21, (26) Sx22, (27) Sx23, (28) branco 
Os primers niaDF2 - niaDR4 e niaDF2 - niaDR2, apresentaram todos os produtos de amplificação com aproximadamente 670 pb e 1200 pb respectivamente. Todos os mutantes niaD analisados não apresentaram nenhum fragmento de inserção inseridos nos mutantes niaD (Figura 24 e 25).

Os primers niaDCDSF - niaDCDSR, apresentaram os produto de amplificação com aproximadamente 2900 pb. Dos 23 mutantes analisados, apenas o mutante Sx2 não apresentou amplificação, as prováveis explicações para este evento podem ser: a primeira, o segmento de inserção poderia ter se inserido dentro da região amplificada do primer niaDCDSF - niaDCDSR, acarretando um produto de amplificação muito extenso, o que não permitiu sua amplificação; a segunda, o segmento de inserção teria se inserido sobre a região do primers niaDCDSF não permitindo o reconhecimento da região e portanto sua amplificação (Figura 26). Testes utilizando o primer niaDCRDF e niaDR4 foram realizados, mas não obteve-se amplificação para o mutante Sx2.

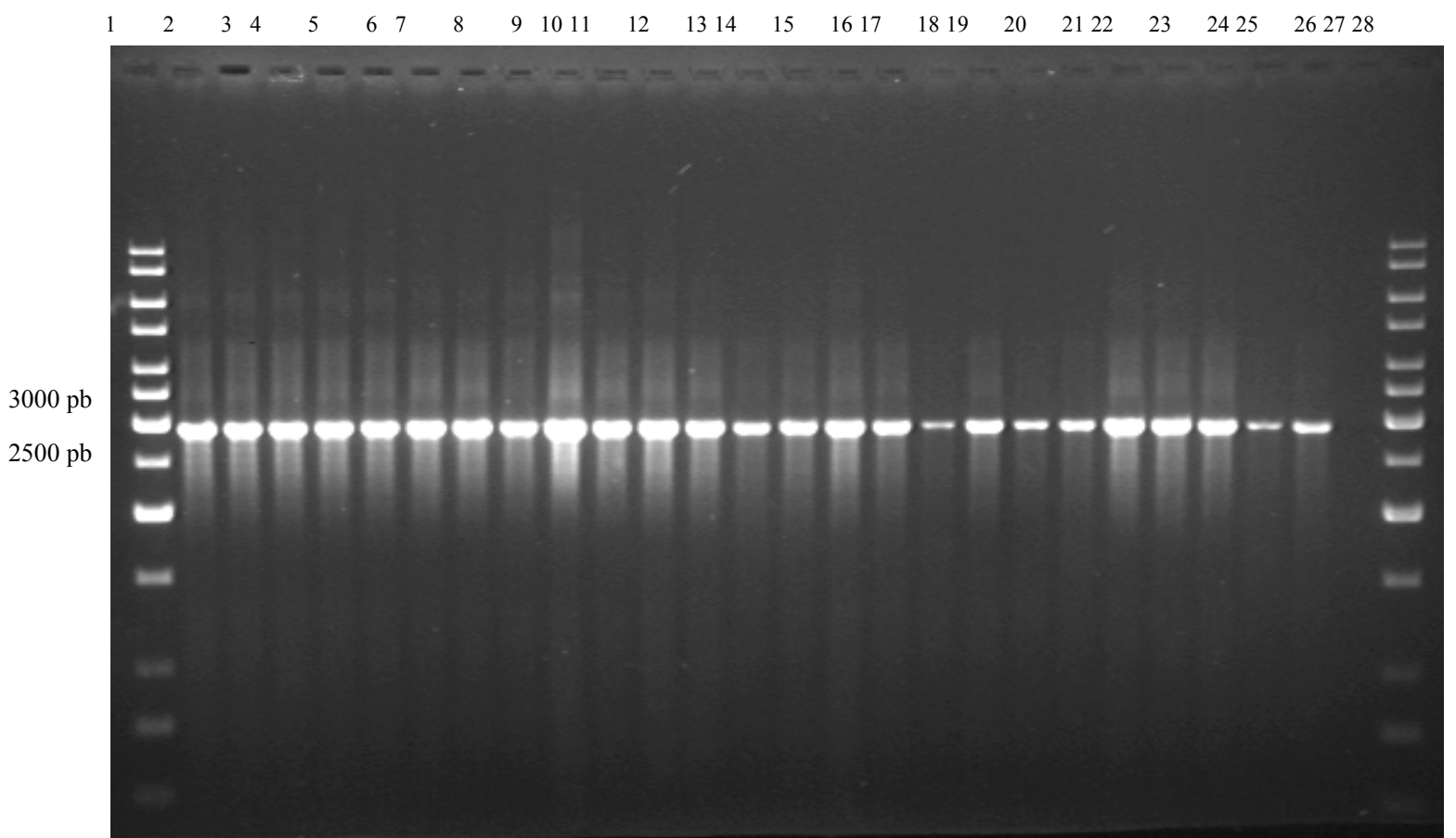

Figura 28 - Primers niaDCDSF - niaDCESR. (1) marcador $1 \mathrm{~Kb}$, (2) MSE, (3) A, (4) G125, (5) $\mathrm{Sx} 1$, (6) Sx2, (7) Sx3, (8) Sx4, (9) Sx5, (10) Sx6, (11) Sx7, (12) Sx8, (13) Sx9, (14) Sx10, (15) Sx11, (16) Sx12, (17) Sx13, (18) Sx14, (19) Sx15, (20) Sx16, (21) Sx17, (22) Sx18, (23) Sx19, (24) Sx20, (25) Sx21, (26) Sx22, (27) Sx23, (28) branco 
A linhagem MSE e os mutantes Sx11, Sx12, Sx13 e Sx16 foram seqüenciados para verificar se o produto de amplificação era pertencente ao gene niaD (Anexos C e E).

\subsubsection{Análise Molecular com primers para transposase e transcriptase reversa}

Os primers Fot1.1F - Fot 1.1R, para a amplificação do gene da transposase (para localização do elemento de transposição) foram construídos utilizando as seqüências da transposase dos fungos filamentosos Fusarium oxysporum (Elemento Fot1 - X64799.1), Fusarium solani (Elemento Fot1- AF443562.1), Nectria haematococca (Elemento Nht1 - AF443563.1) e Neocosmospora sp. (Elemento Fot1AF434909.1). Todas as seqüências utilizadas foramo depositadas no GeneBank - NCBI. Os primers Fot1 F e Fot1 R, foram construídos por Migheli et al (1999), sendo seqüências específicas para a amplificação do gene da transposase da família dos Elementos de Transposição Pogo. Os primers ns5 F e ns3 R, foram construídos por HuaVan et al. (2001), sendo seqüências específicas para a amplificação do gene da transposase da família dos elementos de transposição Ant1 e Tc1, precisamente o elemento Impala. O primer Gyp F - Gyp R, para a amplificação do gene da transcriptase reversa (para localização do elemento de transposição) foram construídos utilizando as seqüências das transcriptase reversa dos fungos filamentosos Fusarium oxysporum (Elemento Forest - AF076627) e Magnaporthe grisea (Elemento MAGGY - L35053).

Nenhum dos primers específicos utilizados, tanto para transposase como para transcriptase reversa, deram resultados positivos, isto é, nenhum deles amplificou, mesmo utilizando temperaturas baixas de anelamento ou diferentes diluições de DNA. Com este resultado foi possível verificar que o segmento de inserção da linhagem A de A. nidulans, não pertence às famílias Pogo e Impala de transposons e nem a família Gypsy de retrotransposons. Estas duas famílias (Pogo e Impala) de transposon e a família (Gypsy) de retrotransposon foram escolhidas para este estudo, pois são de grande ocorrência em diversos fungos filamentosos (Daboussi \& Capy, 2003). 


\subsubsection{Análise Molecular com primers para Transposon MATE}

Em A. nidulans até 1990 nenhum elemento de transposição havia sido descrito. Kupfer et al. (1990) descreveram uma região semelhante a um elemento de transposição no cromossomo VIII, mas este era inativo. Nielsen et al. (2001) descreveram dois retrotransposon neste fungo, o Dane1 e o Dane2 (Degenerated Aspergillus nidulans element), mas estes também eram inativos. Os elementos descritos em A. nidulans apresentavam semelhanças com as famílias Impala e Gypsy, os quais já haviam sido utilizados como primers específicos, dando resultados negativos.

Clutterbuck (2004) descreveu um segmento de inserção, MATE (ㅆobile

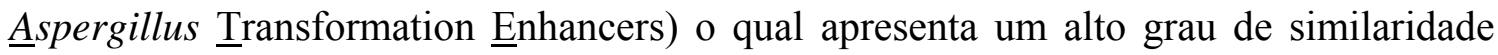
com seqüências características de elementos de transposição, incluindo uma seqüência potencial Met-tRNA similar a encontrada em retrotransposon do grupo Ty-copia. Esta sequiência de nucleotídeo não é encontrada em toda a extensão de MATE, mas uma pequena seqüência "Spe-motif". O motivo "Spe" consiste de um sítio de reconhecimento de toposisomerase I, além de apresentar um sítio alvo ilegítimo de eventos de recombinação.

Por meio dos elementos descritos por Clutterbuck (2004), o MATE 1a e MATE $1 \mathrm{~b}$ encontrados no cromossomo IV, MATE 4 encontrado no cromossomo VI, MATE 5 encontrado no cromossomo I e MATE 9 encontrado no cromossomo VII, foi construído um par de primers, para amplificação dos mutantes niaD isolados (Figura 27) e dos variantes deteriorados V5, V101, V102, V103 e V104 (Figura 28).

A amplificação dos mutantes nia $\mathrm{D}$, foi irregular, sendo que os mutantes Sx11, Sx12, Sx16, Sx17, Sx20, Sx21 e o padrão G125 não amplificaram, mesmo variando as diluições do DNA. Acredita-se que este problema pode estar relacionado com a qualidade do DNA, uma vez que este mutantes apresentam DNA pigmentado. Alguns dos mutantes que amplificaram foram seqüenciados para comprovar se eram segmentos dos transposons MATE (Anexo D e E)

Os variantes deteriorados analisados V5, V101, V102, V103 e V104 foram amplificados, demonstrando a existência da seqüência MATE em seus genomas. 


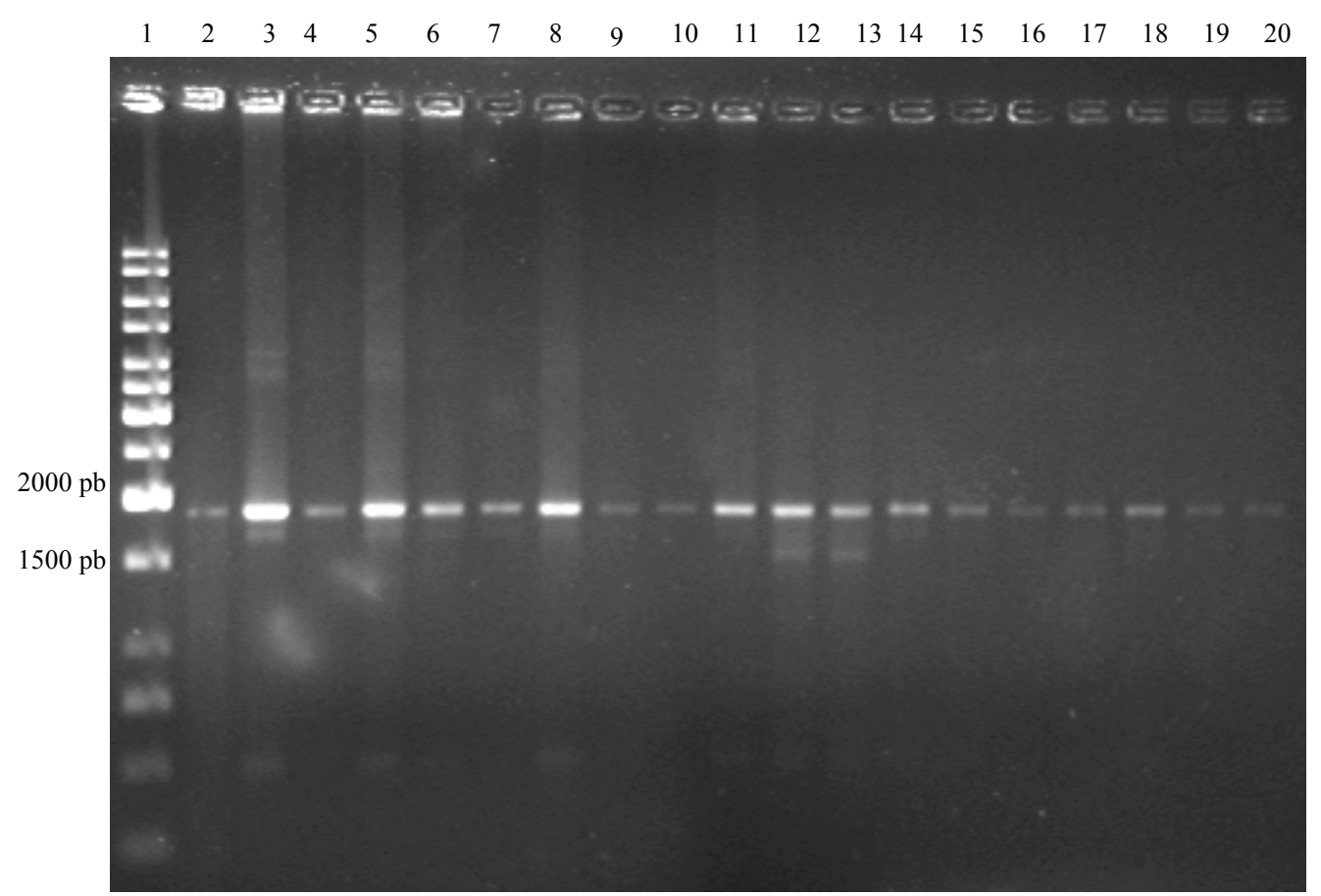

Figura 27 - Primers mateF - mateR. (1) marcador $1 \mathrm{~Kb}$, (2) MSE, (3) A, (4)Sx1, (5) Sx2, (6) Sx3, (7) Sx4, (8) Sx5, (9) Sx6, (10) Sx7, (11) Sx8, (12) Sx9, (13) Sx10, (14) Sx13, (15) Sx14, (16) Sx15, (17) Sx18, (18) Sx19, (19) Sx22, (20) Sx23

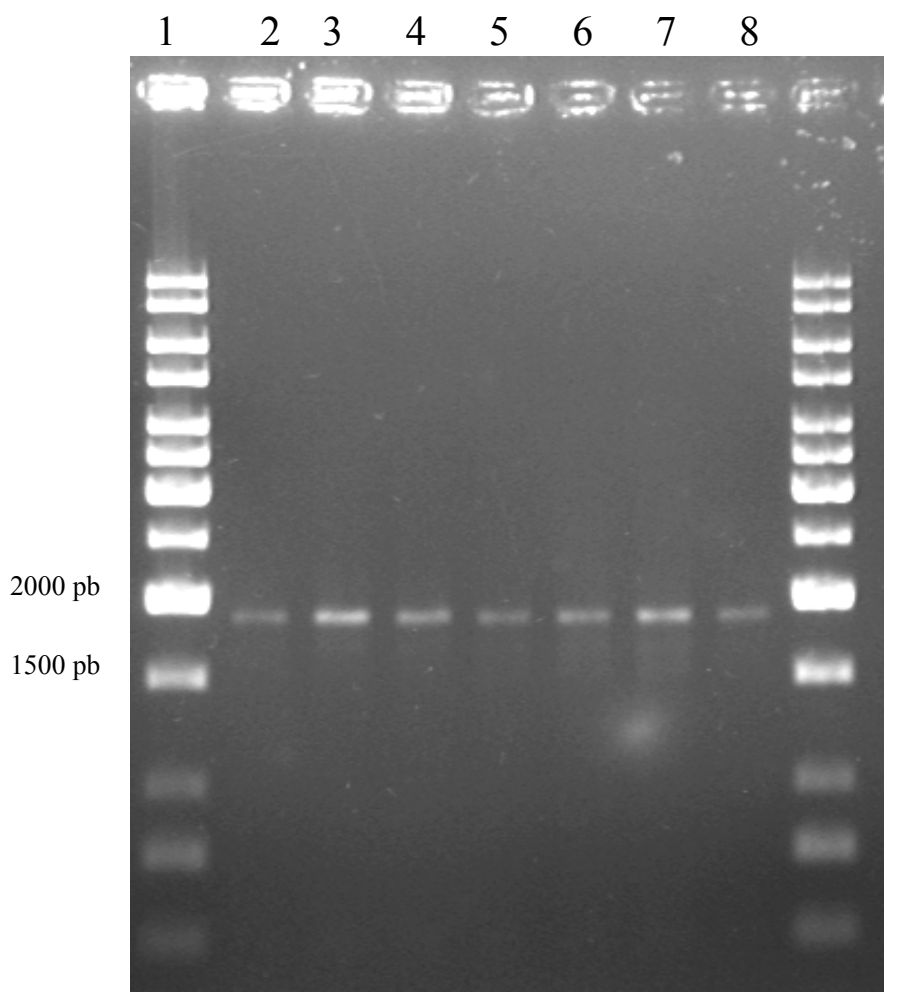

Figura 28 - Primers mateF - mateR. (1) marcador $1 \mathrm{~Kb}$, (2) MSE, (3) A, (4)V5, (5) V101, (6) V102, (7) V103, (8) V104 
$\mathrm{O}$ sequenciamento de alguns dos mutantes niaD, mostrou que as seqüências analisadas apresentam as características descritas por Clutterbuck (2004) como um pequeno segmento da região palíndrome, responsável pela formação de uma estrutura "stem-loop", a qual acredita-se que seja responsável pelo mecanismo de transposição do elemento MATE e várias repetições motivo "Spe-motifs" (RWCTAGWY).

Reunindo as informações disponíveis neste trabalho, sobre os mutantes nia $\mathrm{D}$ e os variantes deteriorados analisados com o primer mateF - mateR, não podemos discernir exatamente se o elemento de transposição MATE exerce sua função de transposon nestas linhagens, principalmente nos variantes deteriorados. Para comprovarmos sua presença e sua atividade seriam necessários as análise por "Southern blot" dos mutantes niaD, clonagem do transposon e sequenciamento. Posteriormente, estando o elemento clonado, seria interessante transformá-lo em um outro fungo filamentosos, para verificar sua atividade (Queiroz \& Daboussi, 2003).

Podemos afirmar, contudo que o elemento MATE esta presente na linhagem $\mathrm{A}$, nos variantes deteriorados e nos mutantes niaD, este dois últimos são originários da linhagem A.

A presença do transposon MATE nos variantes deteriorados, principalmente os analisados neste trabalho (V5, V101, V102, V103 e V104), demonstram as dificuldades que ocorrem para determinar a localização dos segmentos de inserção (transposon MATE) em um dos oito cromossomos de A. nidulans. Como os transposons podem estar presentes em mais de uma cópia no genoma, isto já mostra as dificuldades e variações encontradas durante as análises genéticas para mapear a localização do segmento de inserção nos cromossomos. A presença MATE também explicaria as mutações nos genes de ciclo celular e desenvolvimento do conidióforo, uma vez que o transposon pode estar se inserido em algum gene para o ciclo celular (Nishimura et al., 2000) o que poderia desencadear uma séria de anormalidades até o desenvolvimento do conidióforo.

Interssante no presente trabalho foi a deteç̧ão de MATE na linhagem MSE, a qual não apresenta duplicação cromossômica, sendo uma linhagem estável. 
Clutterbuck (2004) discute a evidência de "repeat-induced point mutation" ("RIP"), o qual consiste no mecanismo de silenciamento de genes. O mecanismo "RIP" foi identificado inicialmente em Neurospora crassa (Selker et al., 1987; Cambareri et al., 1989), este mecanismos consistem em mutações via G:C para A:T em regiões duplicadas, e é altamente regulado ocorrendo em períodos específicos no ciclo sexual, precisamente na fase pré-meiótica (Cogoni, 2001; Ikeda et al., 2002).

Nos elementos MATE 4 e MATE 9 é possível observar substituições de bases, $\mathrm{C} \rightarrow \mathrm{T}$ e $\mathrm{G} \rightarrow \mathrm{A}$, característico do mecanismo RIP. Este mecanismo tipo RIP poderia estar ocorrendo na linhagem MSE uma vez que esta se apresenta estável. Mas somente uma análise mais detalhada da seqüência MATE nesta linhagem MSE poderia explicar a presença do transposon e sua inatividade.

Finalmente, este trabalho apresenta algumas evidências que o transposon MATE pode estar presente e possivelmente ativo na linhagem A, que apresenta duplicação cromossômica, e nos variantes deteriorados, isolados desta linhagem. As evidências para tal suposição baseiam nas análises genéticas que são dificultadas para o mapeamento, dos segmentos de inserção nos cromossomos, nas análises citogenéticas que apresentam anormalidades em todas as fases de desenvolvimento deste fungo e a amplificação de regiões características do elemento MATE, na linhagem A, nos variantes deteriorados e nos mutantes niaD isolados. 


\section{CONCLUSÕES}

As análises genéticas realizadas nos variantes deteriorados mostraram que os determinantes de deterioração podem se inseri em qualquer um dos grupos de ligação independente daqueles envolvidos na duplicação e, na maioria dos casos, apenas um gene está envolvido.

As análises citogenéticas realizadas na linhagem com duplicação cromossômica e nos variantes deteriorados demonstrou que houve alteração na germinação, migração nuclear, deposição de septo e crescimento polarizado da hifa, além de alterações nas estruturas que compõe o conidióforo.

$\mathrm{O}$ estudo realizado via $\mathrm{PCR}$, do segmento de inserção presente na linhagem $\mathrm{A}$, variantes deteriorados e mutantes niaD analisados neste trabalho, são característicos do Elemento de Transposição MATE de Aspergillus nidulans, que apresenta "Spe Motifs" e região palíndrome, responsável pela formação de uma estrutura "stem-loop" responsável pela transposição do elemento MATE. 
ANEXOS 


\section{ANEXO A}

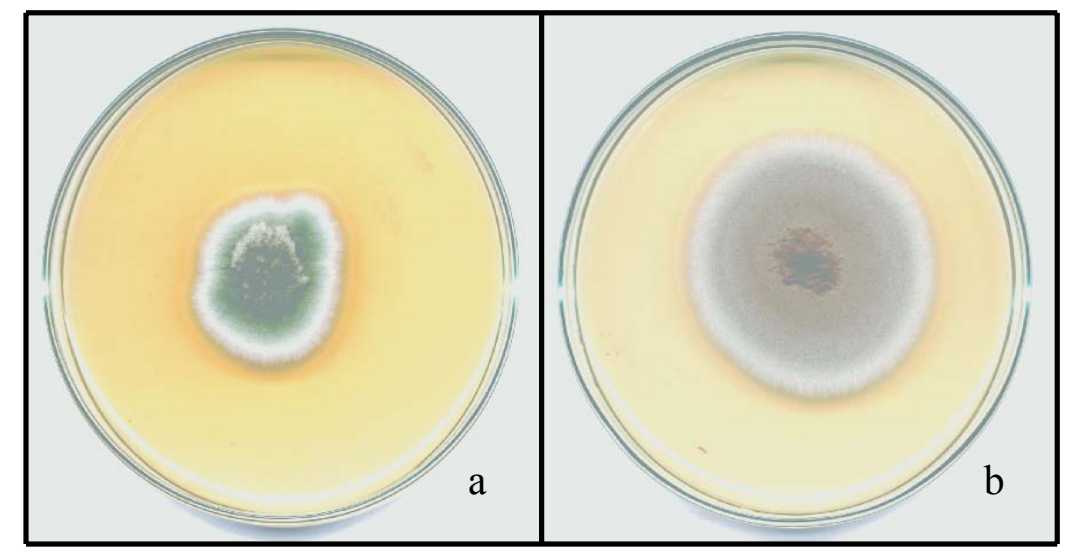

Linhagem G0248 - com os marcadores genéticos: biA 1 , brlA42 (mutante variegado), a. temperatura sensível - normal a $28^{\circ} \mathrm{C}$, b. mutante a $37^{\circ} \mathrm{C}$. 


\begin{abstract}
ANEXO B
Seqüência de nucleotídeos do alelo selvagem brl (L25858 - NCBI)

(Adams et al., 1988). Região grifada, inicio do transcrito $\beta$ e região em itálico e grifada inicio do transcrito $\alpha$. Total de 3411 nucleotídeos.

GGGCCCTGCAGGTTAACAATCGTGGAGCAGGGTCGGTCAATCCTGGTGACGATCCATCTCTATGGGGCGGC AATAATGATTGTGATTCAGATTAGTTCTCCAGGATCGTCATGGAAGCCTAAATGATACAGTACTATCTACT GGACCTAGTTCCAGGCGAGTCTTCTGATACCGAGCAAGCACTCTCTTACGTCGAAGCATTTTTTGCTGAGT TTCGCTTTCTGTCGGGCTCTGGATGGATGGCTCGGAAGTGTTCCAGGTCGTGCATTCCTCAGGGCGATAAA AATAAAGCGTAGTGGTCGGGAGATGAAGAAATGCAGGTCCGGTATCAGCCATTGTGGCCGTCTGTTGGAGC ATGGAGGCCCACCGCAGAAAGGCAGGAAAAAGGAATATTGGCGATAAATTAACCAGGAGAATTAAAATCAA GGCAACGCAAAATAGATTAAGATTCGAAATAATAATCGCACCCTCTCGCCCTCCAGGTTGGCAGACGTGAG GGATGCCACTTTCTCTCTGCTCTGCTCTCCATACAGTGACTCCCTTTTACCACTTTGGGCTTCAGTCGCAG TCTCTTGACCACCCAAGCCATCGATCTGCCTCAAGTGCCAGGGTATATTATCTTTGACCTCCCAACATCTC CATTAACATCATCATCATCATCATCATCATCGTCATCCTCACACCTAAACCACAACCTGCATCATCATCCA GATCCGCCTGAGACATCGGTCCATCCCCGTTGATTCACTTCCATCCCCTTGCTGGCCCTCATCTGATCATC TAGAACGACGTCCCTCTGCAACTGAGACACGAATTACTTTGCTGTCCAGTCAGCCCACTGCATCCTCCTCC AACGCCTCCGATCTACGTGCGGGTTGAGACCCAGGATCCGGACATCGCGTTTAAGGGCGGGTCTATTGAAC CCCTCGACCTCGTTCTTCCCTTCTGCGCAACCCTTCAACGCCTTTTATCCAGAGACACAGGCCTCTCCCGG GAAACAGCTAGTCCAGCCCTCTGTTCACAGTTGTCCAGACCAGGGCAGCTCTGGCGGTTACTCTAGGAACT CGATAGCCTACATTCCTGGCCTTGCTCGGGACCTGGACAGGAACGCGAACGCGCCCCTCCTTCAGCCTTTG CTCTTAGACTCTGGCTGGCACTTCTCCTTTGGGGAAAAGTAATGACTGCCCTCAGTGAGTACGACGATCTT CGAGTTCCTGTTTCTACCCGCCTCCATTTATTCCCTGCGCATTTGTTTATTTCATCCGCCGCTCCTCCTCC ATTCCGGCTCCCCAACCTTCATTCTCTCTCTTCACCAACTCGCTCATTCACTCACTCAATCGTTTCCCTTA CACCCACTCTGGTCTTCATTCTTTTGCTTTGCTCTTCTTCTGCACAGTCTTTTACTGCTGTCGAGATTAGC CCTCTTTCATTCCTTCACTGGCCTCCACTGGCCTCCACCCCACCGGCCTTAGAAGCCATCCCGCTCATTGC TATCCCACATCTTCTGTCTCTCTATCTCATTCAATCATCGCAGCAGATTCTGCAAAGCTTAGGGAACGTAA ACTGAACGGTGCTCTGGCAGGTGAACAAGTCACAGCACCCCTCCAAGAGCGTCGCAGCGCCCCGTCGCTCG AAGACATGCGAAATCAGTCCAGCCTGTCCGATCGTCTGACCGTTGAAGTTGATTGTTCGTCCCTGGGCTCC AACGAGTGCCCGTCTATGACCTCGAGCTTCTCGCCGCTCGAGTCTCCTACACCAACTCCAACAAGTATATA TAGCCAGGGCTCCCTGGAATCACCCGGTTGGCACGGAGCAGGATCACTCCCCAACAACACGTACGAACGAA CTCCTGGTTCTGCTTCGATGCGCAGTGCCTTTCGCCTAGCAGGTATGGCGTCCACGGAGAGTCTGGGACTT CCATACGGTAGCATGGAAGGGCAGGAACGAATGCCTATGCCCGACTTTCTCTCTGGATACGATGAGAATAT TGAACAACTGTGGATGCCCTCAGAAGCACCCAAGTCTTATGATCATGTCGCTCAAGGACTCGCTTACCATC AAGGCATGCATCAGTACCCAACCATGGCGCGCAACACCAACAACAACTACCGTCACCAGGCAGCTGCTTAC CTACCAGAGTCTACGACCAATCCTTGCCTATCACGGTCAATATTCCACCAACCCGAGCGAGTCCCGAGTTC GATGTCTTCGTCCATGTCAATGAATAACATGTTGCCATGGATGAATCTTGGGGACTCGATTGCGCCGCAAA CTATTGCGCCATCACAAGTTGGCCCAGTTACTCCACCACCATCATATACAGACTTTCCGACCTCTCTTAGT GCATTCAAACAACATAGCCCCACTACCCCAATCAGGTCTTGCTCCCTTGGGACAGGGTCAGGGGCCGATAC CCCGCTGAGCCGGCTTTCAGGGGGGCCGTGCGAATACATGGACGATTTCCAGCCCTCGCCAGTCTACCGCG ACGGGTTTCAGAGGCCGCATCGCGTGGCTTCTAGGAAGATGCTCCGACGACAGACCTCTAAGCAAAACTTA ATGCTAGAGAACCTACCACAGGTCATCAAGCAGGTGCAGTTCAAATGCAAAGAGCCTGGTTGCAACGGCCG GTTCAAGAGGCAAGAACACTTGAAGAGACACATGAAGAGCCACTCAAAAGAGAAGCCGCATGTATGTTGGG TACCAGGTTGTCACCGAGCCTTCTCACGGAGTGACAACCTCAACGCCCACTATACGAAGACCCATAGCAAA CGGGGTGGTCGCAATCGATACGTCGCCACGCTGGACGAGAACAGCCCCGACTACGACCCAGAATTCCGCGG GCAGCTGACGCCAGACGGGCGTCCTATCTACGGGTCAAAGCTGGATGACCCCATCCCGGGCGCGGGCGATA TGAGCCTGGACGGCTGGGATGAATGAAACAGAAACAAAGAGGGCTGATCTGCATGGAATCTAATATGATAC CCGCGGGCTCGATCTACGCCAAACTTTCCTTATATCTTTGACTCAGGCAGACCCGGCGCTCTACGGTGTTA ACTTCTACCCGCCTCGGTGTTCTTTTTCCCACCTTTTCTCTTCGCTTTCCTGTAGAACATTACTGGTTTGG ATTCGTCCTGGATCACCCAATGGCTATTTACAAGGTCGAAACAAAATAATCTAATTGCATCAAAACGGGCA
\end{abstract}


GCTGCGCAACAACGGAGTGGGGGAGTCGGGATTCTGTACTGTACAATTGACAGTGACTTGGTTTAACTTTC TGATTTTCTAGTTGATCTATCGATATGTCAACCCCACAAAGCGGGATAATAATAGCTAGCTAGACATGTTC TACGTGTTAGTCTCTTTAGAAATAGGTAGATAAAATGCCACCGCTGGGTGATTTCTTGGTTGTTCCTCGTC GAC

Seqüência de nucleotídeos do variante deteriorado V5. Região e negrito e grifada, inicio do transcrito $\beta$ e região em itálico e grifada inicio do transcrito $\alpha$. Total de 1750 nucleotídeos.

GGGCCCTGCAGGTTAACAATCGTGGAGCAGGGTCGGTCAATCCTGGTGACGATCCATCTCTATGGGGCGGC AATAATGATTGTGATTCAGATTAGTTCTCCAGGATCGTCATGGAAGCCTAAATGATACAGTACTATCTACT GGACCTAGTTCCAGGCGAGTCTTCTGATACCGAGCAAGCACTCTCTTACGTCGAAGCATTTTTTTGCTGAGT TTCGCTTTCTGTCGGGCTCTGGATGGATGGCTCGGAAGTGTTCCAGGTCGTGCATTCCTCAGGGCGATAAA AATAAAGCGTAGTGGTCGGGAGATGAAGAAATGCAGGTCCGGTATCAGCCATTGTGGCCGTCTGTTGGAGC ATGGAGGCCCACCGCAGAAAGGCAGGAAAAAGGAATATTGGCGATAAATTAACCAGGAGAATTAAAATCAA GGCAACGCAAAATAGATTAAGATTCGAAATAATAATCGCACCCTCTCGCCCTCCAGGTTGGCAGACGTGAG GGATGCCACTTTCTCTCTGCTCTGCTCTCCATACAGTGACTCCCTTTTACCACTTTGGGCTTCAGTCGCAG TCTCTTGACCACCCAAGCCATCGATCTGCCTCAAGTGCCAGGGTATATTATCTTTGACCTCCCAACATCTC CATTAACATCATCATCATCATCATCATCATCGTCATCCTCACACCTAAACCACAACCTGCATCATCATCCA GATCCGCCTGAGACATCGGTCCATCCCCGTTGATTCACTTCCATCCCCTTGCTGGCCCTCATCTGATCATC TAGAACGACGTCCCTCTGCAACTGAGACACGAATTACTTTGCTGTCCAGTCAGCCCACTGCATCCTCCTCC AACGCCTCCGATCTACGTGCGGGTTGAGACCCAGGATCCGGACATCGCGTTTAAGGGCGGGTCTATTGAAC CCCTCGACCTCGTTCTTCCCTTCTGCGCAACCCTTCAACGCCTTTTATCCAGAGACACAGGCCTCTCCCGG GAAACAGCTAGTCCAGCCCTCTGTTCACAGTTGTCCAGACCAGGGCAGCTCTGGCGGTTACTCTAGGAACT CGATAGCCTACATTCCTGGCCTTGCTCGGGACCTGGACAGGAACGCGAACGCGCCCCTCCTTCAGCCTTTG CTCTTAGACTCTGGCTGGCACTTCTCCTTTGGGGAAAAGTAATGACTGCCCTCAGTGAGTACGACGATCTT CGAGTTCCTGTTTCTACCCGCCTCCATTTATTCCCTGCGCATTTGTTTATTTTCATCCGCCGCTCCTCCTCC ATTCCGGCTCCCCAACCTTCATTCTCTCTCTTCACCAACTCGCTCATTCACTCACTCAATCGTTTCCCTTA CACCCACTCTGGTCTTCATTCTTTTGCTTTGCTCTTCTTCTGCACAGTCTTTTACTGCTGTCGAGATTAGC ССTСTTTCATTCCTTCACTGGCCTCCACTGGCCTCCACCCCACCGGCCTTAGAAGCCATCCCGCTCATTGC TATCCCACATCTTCTGTCTCTCTATCTCATTCAATCATCGCAGCAGATTCTGCAAAGCTTAGGGAACGTAA ACTGAACGGTGCTCTGGCAGGTGAACAAGTCACAGCACCCCTCCAAGAGCGTCGCAGCGCCCCGTCGCTCG AAGACATGCGAAATCAGTCCAGCCTGTCCGATCGTCTGACCGTTGAAGTTGATTGTTCGTCCCTGGGCTCC AACGAGTGCCCGTCTATGACCTCGAGCTTCTCGCCGCTCGAGTCTC 


\begin{abstract}
ANEXO C
Seqüência de nucleotídeos do alelo selvagem niaD (M58291- NCBI)
\end{abstract}

(Johnstone et al., 1990). Total de 3618 nucleotídeos.

GGATCCAGCATATTGCCTGCTGTCCTTAGAATTAGAAAACGAAAATACTCTGTTTCTCCGAGGCTGAAAGG CAGCGGGCGGCTGCCAACTGTATTTCGTCTTATTTTGTCTCGTTTTGTCTTGATTTGGTCTTATTCCATCT GTTTTCGTCTCATTTCGTCAGATCCCGCCGGCCTTTGTATTTGACGAACTACATATCCCCCACGTCAGCCT GGAGCCAGAACCCGTGCCCTATACTATCTAATCGACCTTGATCTGGCATATCTACCAGTTCATGCCGTGGT CGCTGCGAATTCTTCAGTAATCTGTACCTCTATATTATTTTCCTATCCCATACTCTCACAATGTCTACAAC CGTCACACAAGTGCGGACGGGCTCCATACCCAAGACTCTCAAGACTTCCCAGATCAGGGTCGAAGAGCAAG AGATCACAGAGCTCGATACTGCAGATATTCCTTTACCTCCTCCTTCGAAAGAACCAACCGAGGTTCTAAGT CTAGATAAAACTACACCAGATAGCCATGTCCCCCGAGATCCCCGGCTGATCCGGCTCACTGGCGTTCACCC GTTCAATGTCGAGCCTCCATTGACAGCACTCTTTCAGCAAGGTACGCTCTATGGATCTATGGTATATCCTT ACCTTGTCTTCGAATCGAAAAGCTTACAGTCTTAGGCTTCTTGACGCCTCCTGAGCTATTCTACGTCCGGA ATCATGGCCCAGTGCCCCATGTTCGCGACGAGGACATTCCCAACTGGGAACTCCGCATTGAAGGGTCCGTC AGTCTCGTTTCAGCTTGTGAACTACTCCCTGACAAGTGCTAGACTCGTTGAAAAGCCAATCACCCTCAGCT TCAAGCAGATCCTGCAGAACTATGATCAGATCACAGCTCCTATTACACTAGTATGTGCAGGCAACAGACGG AAAGAGCAAAACACAGTACGGAAATCGAAAGGCTTCTCATGGGGCTCGGCCGCTCTGTCTACTGCGCTCTT CACCGGGCCCATGATGGCCGATATCATAAAGAGCGCCAAGCCCCTGCGAAGAGCAAAGTATGTCTGCATGG AGGGTGCCGATAACTTGGTATGTCCGCGTGAATGAAGCCCTGTCTTAGAGGATCAGGGTTAGTTGATCCGT CTAACGTTTATAGCCGAACGGAAATTACGGGACATCCATCAAACTCAACTGGGCCATGGACCCGAATAGAG GCATTATGCTCGCGCACAAGATGAACGGCGAAGACCTCAGACCAGACCACGGTCGTCCGCTGAGGGCCGTC GTACCGGGCCAGATTGGAGGGCGCAGTGTCAAGTGGCTGAAGAAGCTTATCATCACCGACGCGCCCAGCGA TAACTGGTACCATATTTATGACAACAGGGTGCTACCGTACGTCTCATCTCGTTGACTGTTATTTCTCACTC ATACTAATGGTCTGCAGTACAATGGTCACGCCAGATATGTCGTCCCAAAACCCGTCATGGTGGCGCGATGA ACGCTACGCCATCTACGATCTGAACGTCAATTCCGCCGCCGTCTACCCCCAGCACAAGGAAACCCTGGATC TGGCCGCCGCGAGGCCGTTCTACACAGCAAAAGGGTATGCCTATGCAGGAGGCGGACGAAGAATAACCCGT GTCGAGATCTCGCTGGATAAGGGCAAATGTACGCTTCCTAACTACCAAGCCCATAAATCTGCATCCCGTTG AATCCACTGCTAACATCTTACAGCATGGCGCCTTGCGCGGATCGAATACGCCGAAGACAAATACCGCGACT TCGAAGGTACGCTCTATGGCGGCCGCGTCGACATGGCCTGGCGAGAAGCCTGCTTCTGCTGGTCCTTCTGG TCCCTCGACATTCCCGTCTCGGAACTCGCAAGCAGTGATGCCCTACTCGTCCGCGCAATGGACGAAGCACT TAGTCTCCAACCAAAGGATATGTACTGGTCTGTCCTTGGTATGATGAACAACCCTTGGTTCCGGGTCAAGA TCACCAACGAGAATGGGCGGTTGCTCTTCGAGCATCCGACTGATATCACTGGCTCGAGCGGGTGGATGGAA CAAATCAAGAAAGCAGGAGGCGACTTGACGAATGGGAACTGGGGCGAGAGGCAGGAGGGTGAGGAGCCTGT TGAAGCGGAGCCCGTGGTGGAGGTCAATATGAAGAAAGAGGGCGTGACGAGGATCATTGATCTAGAGGAGT TCAAAAAGAACTCGTCGGACGAGAGGCCCTGGTTCGTCGTTAACGGGGAGGTATATGATGGCACAGCATTC CTAGAGGGACACCCCGGCGGAGCTCAGAGTATCATCTCGGCTGCTGGAACGGATGCTTCTGAGGAGTTCCT CGAAATCCGTAAGTTCTCCAACCCTGGCCCTCTATTATGTCCTTCTAACGTCATGATAGACAGCGAAACCG CCAAAAAGATGATGCCAGACTACCATATCGGCACCCTCGACAAAGCCTCGCTCGAAGCCCTTAGAAAGGGC AACGCAGACACAACAGACTCATCCAGCGATCCCCGCCCTACTTTCCTTACCCCCAAAGCCTGGACAAAAGC TACTCTGACGAAGAAAACATCTGTCTCCTCCGACACGCACATTTTCACTCTCTCCCTTGAGCACCCATCCC AAGCCCTCGGCCTTCCAACGGGCCAGCACCTGATGCTCAAAACCCCCGACCCAAAGTCCTCGAGCTCAGGC AGCATTATCCGCTCGTACACCCCGATATCACCATCCGATCAGCTGGGAATGGTCGACATTCTCATCAAAAT CTACGCCGAGACACCCAGCATCCCCGGCGGCAAGATGACCACAGCCCTAGATACCCTGCCGCTCGGTTCCG TCATCGAATGCAAGGGTCCTACTGGGCGTTTCGAGTATCTAGACCGCGGAAGGGTCCTCATTAGCGGAAAG GAAAGATTTGTCAAGTCTTTCGTCATGATCTGTGGCGGGACGGGCATCACGCCTGTCTTCCAAGTCCTTAG GGCTGTTATGCAAGATGAACAAGATGAAACGAAATGTGTCATGCTTGATGGAAACCGGCTAGAGGAAGACA TTTTGCTGAAGAACGAGCTAGACGAATTCGAGGCTTTGGCCGGGAAGAAAGAGAAGTGCAAAATTGTGCAT ACACTGACGAAGGGGAGTGAAAGTTGGACTGGGCGGAGGGGACGTATTGATGAAGAATTGATTAGGCAGCA 
TGCCGGGACACCGGATAGAGAGACCATGGTTTTGGTTTGCGGGCCTGAGGCGATGGAGAAGGCTTCAAAGA AGATCCTACTGTCGTTGGGATGGAAAGAGGAGAACCTTCATTACTTCTAGACGGGTTCGCATAGGTTTGGG GTTGTATCTTGGCGTTGGGACGGACTGGGTATGGTGTTTCTTTTGGATATATGACATGATATGTACAGGCC GTGAATCTTTAACTTTATATCATTATAGAAATGCACTTGCACATTTCAACACGCTGCGAGCAGAATCTCGA AGATTGTTCCGCAAGTATTAGATCATGAGAGCATTATCATTTCCTTTCAGGCAGTGGGAGTAGGCCATCCT GAAAACAAGGCGGCCACTGTAGACTAGTAATACCTCTTCATATCCAACCTGTACCAGAAGATTGATCC

Seqüência de nucleotídeos do gene niaD da linhagem MSE. Total de 2311 nucleotídeos.

CTTATCATCACCGACGCGCCCAGCGATAACTTGGTACCATATTTATGACAACAGGGTGCTACCGTACGTCT CATCTCGTTGACTGTTATTTCTCACTCATACTAATGGTCTGCAGTACAATGGTCACGCCAGATATGTCGTC CCAAAACCCGTCATGGTGGCGCGATGAACGCTACGCCATCTACGATCTGAACGTCAATTCCGCCGCCGTCT ACCCCCAGCACAAGGAAACCCTGGTATCTGGCCGCCGCGAGGCCGTTCTACACAGCAAAAGGGTATGCCTA TGCAGGAGGCGGACGAANAATAACCCGTGTCGAGATCTCGCTGGATAAGGGCAAATGTACGCTTCCTAACT ACCAAGCCCATAAATCTGCATCCCGTTGAATCCACTGCTAACATCTTACAGCATGGCGCCTTGCGCGGATC GAATACGCCGAAGACAAATACCGCGACTTCGAAGGTACGCTCTATGGCGGCCGCGTCGACATGGCCTGGCG AGAAGCCTGCTTCTGCTGGTCCTTCTGGTCCCTCGACATTCCCGTCTCGGAACTCGCAAGCAGTGATGCCC TACTCGTCCGCGCAATGGACGAAGCACTTAGTCTCCAACCAAAGGATATGTACTGGTCTGTCCTTGGGTAT GATGAACAACCCTTGTGTTCCGGGTCAAGATCACCACGGGTCNGNTTCAANAGGGTCNTCACCCTCNTGCC TTTTGCCCCAGTTCCCATTTGTCAAGTCGCCTCCTGCTTTNTTGATTTGTTCCATCCACCCGCTCGAGCCA GTGATATCAGTCGGATGCTCGAAGAGCAACCGCCCATTCTCGTTGGTGATCTTGACCCGGAACACAAGGGT TGTTCATCATACCCAAGGACAGACCAGTACATATCCTTTGGTTGGAGACTAAGTGCTTCGTCCATTGCGCG GACGAGTAGGGCATCACTGCTTGCGAGTTCCGAGACGGGAATGTCGAGGGACCAGAAGGACCAGCAGAAGC AGGCTTCTCGCCAGGCCATGTCGACGCGGCCGCCATAGAGCGTACCTTCGAAGTCGCGGTATTTGTCTTCG GCGTATTCGATCCGCGCAAGGCGCCATGCTGTAAGATGTTAGCAGTGGATTCAACGGGATGCAGATTTATG GGCTTGGTAGTTAGGAAGCGTACATTTGCCCTTATCCAGCGAGATCTCGACACGGGTTATTNTTCGTCCGC CTCCTGCATAGGCATACCCTTTTGCTGTGTAGAACGGCCTCGCGGCGGCCAGATACCAGGGTTTCCTTGTG CTGGGGGTAGACGGCGGCGGAATTGACGTTCAGATCGTAGATGGCGTAGCGTTCATCGCGCCACCATGACG GGTTTTGGGACGACATATCTGGCGTGACCATTGTACTGCAGACCATTAGTATGAGTGAGAAATAACAGTCA ACGAGATGAGACGTACGGTAGCACCCTGTTGTCATAAATATGGTACCAAGTTATCGCTGGGCGCGTCGGTG ATGATAAGGAGTTTGATGGATGTCCCGTAATTTCCGTTCGGCTATAAACGTTAGACGGATCAACTAACCCT GATCCTCTAAGAACAGGGCTTCATTCACGCGGACATACCAAGTTATCGGCACCCTCCATGCAGACATACTT TGCTCTTCGCAGGGGCTTGGCGCTCTTTATGATATCGGCCATCATGGGCCCGGTGAAGAGCGCAGTAGACA GAGCGGCCGAGCCCCATGAGAAGCCTTTCGATTTCCGTACTGTGTTTTTGGTCTTTCCGTCTGTTGCCTGCA CATACTAGTGTAATAGGAGCTGTGATCTGATCATAGTTCTGCAGGATCTGCTTGAAGCTGAGGGTGATTGG CTTTTCAACGAGTCTAGCACTTGTCAGGGAGTAGTTCACAAGCTGAAACGAGACTGACGGACCCTTCAATG CGGAGTTCCCAGTTGGGAATGTCCTCGTCGCGAACATGGGGCACTGGGCCATGATTCCGGACGTAGAATAG CTCAGGAGGCGTCAAGAAGCCTAAGACTGTAAGCTTTTCGATTCGAAGACAAGGTAAGGATATACCATAGA TCCATAGAGCGTACCTTGCTGAAAGAGTGCTGTCAATGGAGGCTCGACATTGAACGGGTGAACGCCAGTGA GCCGGATCAGCCGGGGATCTCGGGGGACATGGCTATCTGGTGTAGTTTTATCTAGACTTAGAACCTCGGCT TGGTTCTTTCGAAGGAGGAGGTAAAGGAATATCTGCAGTATCGAGCTCTGTGATCTCTTGCTCTTCGATCC CTGATCTGGGAAGTCTTGAGAGTCGTTGGGTATGGAGCC

Seqüência de nucleotídeos do mutante Sx11. Total de 1703 nucleotídeos.

GGGCTCCATACCCAAGACTCTCAAGACTTCCCAGATCAGGGATCGAAGAGCAAGAGATCACAGAGCTCGAT ACTGCAGATATTCCTTTACCTCCTCCTTCGAAAGAACCAAGCCGAGGTTCTAAGTCTAGATAAAACTACAC CAGATAGCCATGTCCCCCGAGATCCCCGGCTGATCCGGCTCACTGGCGTTCACCCGTTCAATGTCGAGCCT CCATTGACAGCACTCTTTCAGCAAGGTACGCTCTATGGATCTATGGTATATCCTTACCTTGTCTTCGAATC GAAAAGCTTACAGTCTTAGGCTTCTTGACGCCTCCTGAGCTATTCTACGTCCGGAATCATGGCCCAGTGCC CCATGTTCGCGACGAGGACATTCCCAACTGGGAACTCCGCATTGAAGGGTCCGTCAGTCTCGTTTCAGCTT GTGAACTACTCCCTGACAAGTGCTAGACTCGTTGAAAAGCCAATCACCCTCAGCTTCAAGCAGATCCTGCA 
GAACTATGATCAGATCACAGCTCCTATTACACTAGTATGTGCAGGCAACAGACGGAAAGAGCAAAACACAG TACGGAAATCGAAAGGCTTCTCATGGGGCTCGGCCGCTCTGTCTACTGCGCTCTTCACCGGGCCCATGATG GCCGATATCATAAAGAGCGCCAAGCCCCTGCGAAGAGCAAAGTATGTCTGCATGGAGGGTGCCGATAACTT GGTATGTCCGCGTGAATGAAGCCCTGTCTTAGAGGATCAGGGTTAGTTGATCCGTCTAACGTTTATAGCCG AACGGAATTACGGGACATCCATCAAACTCANCTGGGCCATGGACCCAAAAGATGATGCCAGANTACCATAT NGGNCCCTTGACAAAGCTCGNTNGAGCCCNTAGAAAGGCAACGCAGACACAACAGACTCATCCAGCGATNC CCNCCCTACTTTTCNTACCCCCAAAGCCTGGACAAAAGCTACTCTGACGAAGAAAACATCTGTCTCCTCCG ACACGCACATTTTCACTCTCTCCCTTGAGCACCCATCCCAAGCCCTCGGCCTTCCAACGGGCCAGCACCTG ATGCTCAAAACCCCCCGACCCAAAGTCCTCGAGCTCAGGCAGCATTATCCGCTCGTACACCCCGATATCAC CATCCGATCAGCTGGGAATGGTCGACATTCTCATCAAAATCTACGCCGAGACACCCAGCATCCCCGGCGGC AAGATGACCACAGCCCTAGATANCCCTGCCGCTCGGTTCCGTCATCGAATGCAAGGGTCCTACTGGGCGTT TCGAGTATCTAGACCGCGGAAGGGTCCTCATTAGCGGAAAGGAAAGATTTGTCAAGTCTTTCGTCATGATC TGTGGCGGGACGGGCATCACGCCTGTCTTCCAAGTCCTTAGGGCTGTTATGCAAGATGAANCAAGATGAAA CGAAATGTGTCATGCTTGATGGAAACCGGCTAGAGGAAGACATTTTGCTGAAGAACGAGCTAGACGAATTC GAGGCTTTGGCCGGGAAGAAAGAGAAGTGCAAAATTGTGCATACACTGACGAAGGGGAGTGAAAGTTGGAC TGGGCGGAGGGGACGTATTGATGAAGAATTGATTAGGCAGCATGCCGGGACACCGGATAGAGAGACCATGG TTTTGGTTTGCGGGCCTGAGGCGATGGAGAAGGCTTCAAAGAAGATCCTACTGTCGTTGGGATGGAAAGA

Seqüência de nucleotídeos do mutante Sx12. Total de 640 nucleotídeos.

CTTATTGTCACCGACGCGCCCAGCGATAACTGGTACCATATTTATGACAACAGGGNTGCTACCGTACGTCT CATCTCGTTGACTGTTATTTCTCACTCATACTAATGGTCTGCAGTACAATGGTCACGCCAGATATGTCGTC CCAAAACCCGTCATGGTGGCGCGATGAACGCTACGCCATCTACGATCTGAACGTCAATTCCGCCGCCGTCT ACCCCCAGCACAAGGAAACCCTGGNATCTGGCCGCCGCGAGGCCGTTCTACACAGCAAAAGGGTATGCCTA TGCAGGAGGCGGACGAANAATAACCCGTGTCGAGATCTCGCTGGATAAGGGCAAATGTACGCTTCCTAACT ACCAAGCCCATAAATCTGCATCCCGTTGAATCCACTGCTAACATCTTACAGCATGGCGCCTTGCGCGGATC GAATACGCCGAAGACAAATACCGCGACTTCGAAGGTACGCTCTATGGCGGCCGCGTCGACATGGCCTGGCG ANAAGCCTGCTTCTGCTGGTCCTTCTGGTCCCTCGACATTCCCGTCTCGGAACTCGCAAGCAGTGATGCCC TACTCGTCCGCGCAATGGACGAAGCACTTAGTCTCCAACCAAAGGATATGTACTGGTCTGTCCTTGGTATG A

Seqüência de nucleotídeos do mutante Sx13. Total de 1998 nucleotídeos.

GATCACAGAGCTCTATCACCGACGCGCCCAGCGATAACTGGTACCATATTTATGACAACAGGGTGCTACCG TACGTCTCATCTCGTTGACTGTTATTTCTCACTCATACTAATGGTCTGCAGTACAATGGTCACGCCAGATA TGTCGTCCCAAAACCCGTCATGGTGGCGCGATGAACGCTACGCCATCTACGATCTGAACGTCAATTCCGCC GCCGTCTACCCCCAGCACAAGGAAACCCTGGNATCTGGCCGCCGCGAGGCCGTTCTACACAGCAAAAGGGT ATGCCTATGCAGGAGGCGGACGAANAATAACCCGTGTCGAGATCTCGCTGGATAAGGGCAAATGTACGCTT CCTAACTACCAAGCCCATAAATCTGCATCCCGTTGAATCCACTGCTAACATCTTACAGCATGGCGCCTTGC GCGGATCGAATACGCCGAAGACAAATACCGCGACTTCGAAGGTACGCTCTATGGCGGCCGCGTCGACATGG CCTGGCGAGAAGCCTGCTTNTGNTGGTCCTTCTGGTCCCTCGACATTCCCGTCTCGGAACTCGCAAGCAGT GATGCCCTACTCGTCCGCGCAATGGACGAAGCACTTAGTCTCCAACCAAAGGATATGTACTGGTCTGTCCT TGGTATGATGAACAACCCTTGGTTCCGGGTCAAGATCACCAACGAGAATGGGCGGTTGCTCTTCGAGCATC CGACTGATATCACTGGCTCGAGCGGGTGGATGGAACAAATCAAGAAAGCAGGAGGCGACTTGACGAATGGG AACTGGGGCGAGAGGCAGGAGGGTGAGGAGCCTGTTGAAGCGGAGCCCGTGGTGGAGGTCAATATGAAGAA AGAGGGCGTGANCGAGGATCATTGATCTAGAGGAGTTCAAAAAGAACTCGTCGGACGAGAGGNCCCTGGTT CGTCGTTAANCGGGGAGGTATATGATGGCACAGCATTCCTAGAGGGACACCCCGGCGGAGCTCAGAGTATC ATCTCGGCTGCTGGAACGGATGCTTCTGAGGAGTTCCTCGAAATCCGTAAGTTCTCCAACCCCTGGCCCTC TATTATGTCCTTCTAACGTCATGATAGACAGCGAAACCGCCAAAAAGATGATGCCAGACTACCATATCGGC ACCCTCGACAAAGCCTCGTCTCGAAGCCCTTAGAAAGGGCAACGCAGACACAACAGACTCATCCAGCGATC CCCGCCCTACTTTCCTTACCCTACTTTCCTTACCCCCAAAGCCTGGACAAAAGNTANTNTGACGAANAAAA CATNTGTCTCNTCCGACACGCACATTTTCACTCTTTCCCTTGAGCACCCATCCCAAGCCNTNGNCNTTCCA ACGGGCCAGCACCTGATGCTCAAAACCCCGACCCAAAGTCCTCGAGCTCAGGCAGCATTATCCGCTCGTAC 
ACCCCGATATCACCATCCGATCAGCTGGGAATGGTCGACATTCTCATCAAAATCTACGCCGAGACACCCAG CATCCCCGGCGGCAAGATGACCACAGCCCTAGATACCCTGCCGCTCGGTTCCGTCATCGAATGCAAGGGTC CTACTGGGCGTTTCGAGTATCTAGACCGCGGAAGGGTCCTCATTAGCGGAAAGGAAAGATTTGTCAAGTCT TTCGTCATGATCTGTGGCGGGACGGGCATCACGCCTGTCTTCCAAGTCCTTAGGGCTGTTATGCAAGATGA ACAAGATGAAACGAAATGTGTCATGCTTGATGGAAACCGGCTAGAGGAAGACATTTTGCTGAAGAACGAGC TAGACGAATTCGAGGCTTTGGCCGGGAAGAAAGAGAAGTGCAAAATTGTGCATACACTGACGAAGGGGAGT GAAAGTTGGACTGGGCGGAGGGGACGTATTGATGAAGAATTGATTAGGCAGCATGCCGGGACACCGGATAG AGAGACCATGGTTTTGGTTTGCGGGCCTGAGGCGATGGAGAAGGCTTCAAAGAAGATCCTACTGTCGTTGG GATGGAAAGA

Seqüência de nucleotídeos do mutante Sx16. Total de 1960 nucleotídeos.

TACTGCATCATCACCGACGCGCCCAGCGATAACTTGGATACCATATTTATGACAACAGGGTGCTACCGTAC GTCTCATCTCGTTGACTGTTATTTCTCACTCATACTAATGGTCTAGCAGTACAATGGTCACGCCAGATATG TCGTCCCAAAACCCGTCATGGTGGCGCGATGAACGCTACGCCATCTACGATCTGAACGTCAATTCCGCCGC CGTCTACCCCCAGCACAAGGAAACCCTGGNATCTGGCCGCCGCGAGGCCGTTCTACACAGCAAAAGGGTAT GCCTATGCAGGAGGCGGACGAANAATAACCCGTGTCGAGATCTCGCTGGATAAGGGCAAATGTACGCTTCC TAACTACCAAGCCCATAAATCTGCATCCCGTTGAATCCACTGCTAACATCTTACAGCATGGCGCCTTGCGC GGATCGAATACGCCGAAGACAAATACCGCGACTTCGAAGGTACGCTCTATGGCGGCCGCGTCGACATGGCC TGGCGANAAGCCTGCTTCTGCTGGTCCTTCTGGTCCCTCGACATTCCCGTCTCGGAACTCGCAAGCAGTGA TGCCCTACTCGTCCGCGCAATGGACGAAGCACTTAGTCTCCAACCAAAGGATATGTACTGGTCTGTCCTTG GGTATGATGAACAACCCTTGGTTCCGGGTCAANATCACCAACGAGAATGGGCGGTTGCTCTTCGAGCATCC GACTGATATCACTGGCTCGAGCGGGTGGATGGAACAAATCAAGAAAGNCAGGAGGCGACTTGACGAATGGG AANCTGGGGCGAGAGGCAGGAGGGTGAGGAGCCTGTTGAAGCGGAGCCCGTGGTGGAGGTCAATATGAAGA AAGAGGGCGTGANCGAGGATCATTGATCTAGAGGAGTTCAAAAAGAACTCGTCGGACGAGAGGNCCCTGGT TCGTCGTTAANCGGGGAGGTATATGATGGCACAGCATTCCTAGAGGGACACCCCGGCGGAGCTCAGAGTAT CATCTCGGCTGCTGGAACGGATGCTTCTGAGGAGTTCCTCGAAATCCGTAAGTTCTCCAACCCTGGCCCTC TATTATGTCCTTCTAACGTCATGATAGACAGCGAAACCGCCAAAAAGATGATGCCAGACTACCATATCGGC ACCCTCGACAAAGCCTCGTCTCGAAGCCCTTAGAAAGGGCAACGCAGACACAACAGAATNATCCAACGATC CCNGCCCTACTTTCNTANCCCCNAAGCNTGGACCAAAGCTATTCTGACGGAAGAAAACANCTGTNTCCTTC CGACACGCAACATTTTCACTCTNTCCCTTGAGCACCCATCCCAAGCCNTCGGCCTTCCAACGGGCCAGCAC CTGATGCTCAAACCCCCGACCCAAAGTCCTCGAGCTAGGCAGCATTATCCGCTCGTACACCCCGATATCAC CATCCGATCAGCTGGGAATGGTCGACATTCTCATCAAAATNTACGCCGAGACACCCAGCATCCCCGGCGGC AAGATGACCACAGCCCTAGATANCCCTGCCGCTCGGTTCCGTCATCGAATGCAAGGGTCCTACTGGGCGTT TCGAGTATCTAGACCGCGGAAGGGTCCTCATTAGCGGAAAGGAAAGATTTGTCAAGTCTTTCGTCATGATC TGTGGCGGGACGGGCATCACGCCTGTCTTCCAAGTCCTTAGGGCTGTTATGCAAGATGAACCAAGATGAAA CGAAATGTGTCATGCTTGATGGAAACCGGCTAGAGGAAGACATTTTGNCTGAAGAACGAGCTAGACGAATT CGAGGCTTTGGCCGGGAAGAAAGAGAAGTGCAAAATTGTGCATACACTGACGAAGGGGAGTGAAAGTTGGA CTGGGCGGAGGGGACGTACTTGATGAAGAATTGATTAGGCAGCATGCCGGGACACCGGATAGAGAGACCAT GGTTTTGGTTTGCGGGCCTGAGGCGATGGAGAAGGCTTTCAAA 


\section{ANEXO D}

Transposon MATE 5, linhagem FGSC A4 de Aspergillus nidulans (Clutterbuck, 2004) (BK001596), localizado no final do cromossomo I. Região repetitiva encontra-se em itálico e verde. Região "stem loop" em vermelho e grifado. Região do motivo "Spe" (RWCTAGWY) em azul. Região repetitiva em rosa. Total de $6317 \mathrm{pb}$.

CTTTTAGGCGAGACCACATGTGACGTGGTAAATGTCGCGAGCTAACTCTAAGTCGGCTATTCCTCTTTTGA GCGCACTAACCCAAAGGAGTAAGGTCAACTTAGAGTTAGCTAAAATATAATACTACTTGTCAGTAATGGAC TTTTCCTCCTTTATTTACCTCAACTTCAATCTGCCAATAAGAAATAGTCTCAGACTAGTCACTGACTAGTT TGCAACTTGCTGCCACCATGTCTACAACTCTGCAAATTCCAGGTGCTATTGACGTTCCAGAACAGGTACAA GACTTCATTTTTCTTACCTAGTTTGTGACTAGTTGCTAACTAGCAGCAGATTGACAGAGTTATTCTTAGCA ATCATCCAACACGTCCTCTAATCACATCTAAACTTGAATACTGCTATATGTTACCTTACTATCCTGAATCT CATCAGAATAGCTATACCTATATTGTCCTACTTGATCCGAACCAGGTAAGGAGCAGGGAAGATAAGGGAAG ACTTATTAAAAATATTTATTCTATAACTAATAAGGGACTAGTTGCTGACTAGTCACAGACTCAATACCATG CTTGCCAGTTGGAGTGTTATAATACTCAATCACCCTATATTCAAGGCAGGGTTACTTAAATACAGTACTAG TATTCAGGCGTTCAAATATACTCTTATCTCTATCCTAACCTTAGAAATATATACTATTACAAGGTTACAGA AGATGACTGGAACTATATCTGACAGGAGCAACAACTTATTAAAGAGACAGAAATAGATCCTAAAAAACAGA AAGCAATCTCATGAGTAACTAGTCTTTATTTAATTAGAGACTAATCAAGGACTAATTATATTTATATAGAC ATTTCTTTGGTGTGCTTTATATATTTAAGAGATATCAAGCTTGTCAGCTGCAACAAGTAGGGTGTGCTCCT AAGATAATACTTGGCAAAGCTGTAAGTACCTTAGGGTAGACTAGTCTGGGTCTAGTTACTAACTAGTCAGC TTCAAATAGGCCATGCTTTATCTTATATATGTTGCTCTAATTCAACACTGGAAACCCGTATATAAACAACA TTTTTTTGATTCTCTTACATTTTGTACAGATACAGATATCCTATATCTAGCTCAATTATTCGAGCAGAGAG GAATTATTGAACCAAAATACTATGCAATGATTGATACAAGCTGGTCAAAGAGAATATACTGTAACTGCAGT AAGTTATACAGCTAGTCTTGGGCTAGTCTTGGACTAATTACTAACTAATTCTTGCTAAGGCTTTCTGCATG GTGATGATATATTACTAATAAAGTCACAACCTTGTACTGCGATCTTTAATATTATGATTCTATTAGACCTA GAGGCCTTTCCCTATTATCTTTTTATATCAACAGGAATATATACTCATCCTCCACCTCCCTCCAGCTAAGA TCCCTGGCGAAATTGCAGATAAAATCTCTTATATTATTTGTGACATGCAGAATCCTGATCTTCAAATTAGT CAGTACTGCTATTAAACTAATCCCTTTCTAATCTATAATTAGTTGCTAACTAGACTAGGCCAACTTATCCA CAGTCCTCAAATACAGGACTTACTCGCGCGATATAATAAGGACTTAATTATAGGCCTTTATCCTGCTCTAG CAAATATTGTTAAGGGACGTATTTAGATGGATCTTCCTATCTAGACGTGCCGTACGTACAAGAAGGAATCG CTAAAGAAGAAATGAGAAAGAAGGATTGTTGTTGCAAGGAAGTCTTGTAGGTGGCTCACCGCCTTCAGGAC AGCGCAGGCCTTGGCCGAGTCACTAAGGTCTAAGGTCCTTGTATAGGCAAAGGACCCATAACAAATATGGA TTAAATACAGGCTCTTATTTACTAGGAGAAGCTTGTATTTTATCCTAATGGCCAAGATCTTAATGCACTAT AACTAGAATACAACCAGAATAAATATCTTAAGGTATGTAAAGATTAGTCCCTATCTAGTTACTGACTAGTC AGGGATTAGTAGATAACATCTAACTAGCATTATATACAAGAAATCTATTATGAAGGTGATATTACAATTAT TATTTGTATATTGCAAGATCAGGCCAAGCTATTTCAAAGCCTATACTTATTTAAAGTTGACATGTCCTTCA AACGTGTACATGAGGGCAGGTTTAACAAGGTTATCTTTGCTGTTTTTTTAGAGGATCATGGAAAAGGTAAG TATAATACTAGTCCTGCTCTAGTCCCAGACTAGTCAATAACTAATCACCTTCTAGTTATCACACTCCTTCA TGTATTTATGAACCAACAAACAGGCCGTGCCTACTATTTTCTATTTAAAAAGGTCTTTGAGATAATTCATG ATCTTTCAGGCCATCTAGTACAGTTTTTCCATCTTCATAGAACCAGCATTGAAACTATCATTGTTAATATA GATAAAGGACAGAGGGACAGTATGTTTTCTTTGTACACTGACTAGTTACCTACTAGTTGCTAACTAGTTAG GTTTGGGAAAATGCCTACAAGAGCTTGATCCAGAACATCATGAACCAGACTGGCAGTTAGAAAGAATTCTT ATCTTCTGCCAGGTTTATTTTATCTGTGGGATTAAGAATATAATTAGCCAGAACCAATGTTATACAGTCTT ATTTAAGGCAATGATTAGTCTTTTATATGCCCCTACCCGAGCCCAGTATATGGATATTTTAGAGCAATTAC TAGGTAAGTCCAGACCATAACTAGTTAGCAACTAGTAACTGATTGATATAGAGGATCCAACTCCAGGCGTG GCAACTTGGGCTGAACATAAGCTATATCTGGTAGTTTCTGCTGGATTAAATAAAGCTTGCTCACAAATCCC 
TGAACAGTATTTTAATCAAACCTGTATATATACCAATATAGGTAAACAAACCCACCAAAAATTATATGCTT TTAGTAGGAAGCACCTACCAATTCTAAAGGCAGTTACTAGGTAAGTTTCTAAGTCAAGACTAGGCTTTGTT TAGACTCTGACTAGTTCTCATAGTACATATTTTCTTGATATACAAGATATGCATCAGTACTCTGTGCAGAT ATATTATAATATTACCTATTCCTATTGGCCAGACAATGAGATCTTAAGAATTACAGAGAATTTAATCAGGG ACTATAAGTCTAGCCTTGACTAGTGCCTAACTGGTTACTAACCAGTATTAGAAAGAAAATGACACTGTAAT CAGGAGATTAAGGAAGAGGAAAATATAGAAGGAGTACTACCTAGAAGAGCACATCCTTCTAGATCTTTCTT ATCCTCTGGATCTCCATGGCCACGCCGCTCCAGGTCTAGTACCAGGGGTAGGAGTTATACTAGAGGAGTAA GCTGAAGTTCTACACCACAGCAGTAAGTTATAAAGGACTAATCTAGGACTAGTTGCTGACTAGTCTAGGTC TCCATCCCTAGCCCAGATTGCTTCTCAGAACTATCGCAATCAGCAGGCTAGCCATGAACAACATATACTTG ATCTTCGTGAGTGCCAAGCACGTCTAGATTAATATAAGGTAGAGACTCGGCTTATGCAGCAGCGTCTACTA CAGCCAACTAGTCCTCAACTAGTTGGTGTAAATCCAGTGCAATATCCACCTCTACCTGGATATTTACTATC TAGTTCACAACTAGTCAACCCGGGCCTAGTATATGTTCCGCAGATAACTAGAGCTCTGCTATATATGCCCT CTCAAGCACTATTTATTCCATCTACAGAGACTAGTCACCAACTAGTCTATCAAGACTTACAGGGTATATTA CTAAGACTAACTAACCAGAGGCAGGGTAGCAGATTAACAGCTCTATCTCCTTTACTTACAAGGTCTATTAA AAGCCCTTTAGCATCACCAAGCAGAGAATAGATTGTTAAGCTTATTTTTTATATACTATTTTGTAATAGTA CAAAGTTTTTCTACAGTATCTTGTTAAAAATATATATTTGTAGCAGGCTTACCTACATCAAATTAATAAGA GACTAATTATAAACTAAACACACAAGCAAGCTACTTTAGGGTAAAAGTTTATAAATACTTTTTAACATATAA ACATTACTTGTATTTATTATTACAATTAAAGGTAGATAGAAAATCTAGAGACTAGTTAGAAACTAATCTCA GGTTTGCATTAAACTAAATCAGAGCCCGAGAGGTTAACAGAACCTAGAAGGGGACTAGATATCCAGGTAGG GAAACAAAAAAAAAAACAAGACAGTCATATATTAGGGAGACTAGTTAGAAGCTAGTTCCAGGACGAGGAAA ATAAAAGACAATAATACTATAGTCTAGTTGACAACTAGATAGATTCTAGATTAAGGCCAAAGTCTCTGAGA TCCAGGTTAGTTGCAACTAATACTAGTTAGTATCTAGTCTCCTATAACTCTGAAGCTAGAATAACTTACTA CTATTATCCTTACTACTATTTAGCTGTGCAAATAGAGTAATTACAAGGTATTCAGAGACTAGTTATTGACT AGTCAGTAACTAGTAATAACTAATAAGGTATTAACCTACTATATCTGTCATCACCCTGTACTTCCTCAGGC TCAGCAGCCTTTTCCTCCTTATTTTTATACTTATTTTCCTTATTTAAGACTGTGACTAGTCAAAGACTAGT CCAGAACCACAAAGGAGAAATATCTTACTACTTTCTTTATTGCTTGTCTCTTTTGCATTATCCATGTCTGC AACTAGTTAGAGTCTAGTTAGTGACTAGTCCAACAAGGACTTGCTTATCTCCAGATTATTGGAGGAACTCT CCAGGGCCTCAAGATCCACAACAGAGCCTTCTAGAAGACTAGTTAATAACTAGTTGGTCTTTGTCTGAGTC TGACTTACAAGGTTACATACTTGCTCCCTTTGCCTTGTCAATTAATAAGAAAAAGCACCAAAACTTGCAAT ATAGCTTTGAACCACATGGTGCTGAGACTAGTTAGAATCTAGTCCCAAACTAGCTTGGATAGCTTACCTTT GCCCTTTGCGTTGCAACAGGTCTTGTAGGGTATAGTTCCTTTCTTACTAGCTGATTTAGCTGCCTTGCTAC CCTCATGGCAGATCTGCATAAAGAGTAGCTAGAGGTTATAAATTAGCACTGATCCTAGGTACAGGGCTGAA TATAACTTGCCTTTCCTTTCTCATCACACGGCAAGACAGGCTTACTCAAATTCCTACCAGTCACAGGGGTA TGCACAGCGTACGGACCACTTGAACTAGTCACAGATTAGTTAGCAACTAGTCTGCATTGAATGGCTGTACT TACAGGCCCTTGCCATTGTCCTGATCATTTCCAGCTTCACCCTCGTTGCTGCAAAGTAGTTAGTGACTAGT TAAGGACTAGTTGAAATGGGAGAAGAAACTTACAAATTCTTGACACCCTTAGTATTGTGGTCCTTGGACTT GGTACTGCTATATATTAGCTAATATACTAGTTAGACTCACAGAAACTTACGCAGCTTGCTTGTGCTTCTTG GTAGGAGTCAGGGTTGGGAGAACAGTGCCTTTAAACAAGCCTTCATACCATGCTACTTGACTAGTCAGGGA CTAGTTACCAAGTAATCTAGATAGGACTTGCCTTTGGCCTCCATCAGTTCCTTTATAGTGGGAGGTCCATT GTGCAATGTAAACTCCATGCCGTAGGAGTTCTTGTCCTTCAAGTACTTGACCAATATGTTTCTGTTGGCAG AGGGAACCTGTCAACTAGTTAATAACTAGTCAGAAACTAGTATAGCAGTAGACTCACTGTATACTTGAGGC ATCCCTTCACTCAGCAGTAGACTTTATATAGATAGATATCAGGCACGCCATTGTCGTCCTGTAGACTAGTC AGTAACTAGGCTTAAAGCTAGTCAGGTCAGCTTACTATCTTGAAATCCGGCAGCATAAGCTCCCTGTCCTT AACTGCCTCGAGATAGTGACAGTACTCTGGGGACTTTCGGAGATTGTTATCACGAATGCTTGGCATACTAA TTGTTGACTAGTCTTGGACTAGTCCCGAGCAAAAAGGATTGGAGGAGGAGGAGGAAGGTAAGAGTGAGACA AAGAGCAAAATAAGAGCTTCAAAGGCTATCTCTAAGCAGTATGAAGGTTAAGTATCTAGTTCTTGACTAGA TTTAAAAGAGATTTCGACTAGTTATGTACCTGGAGTTTGGATATAGGAATGTGTTGTGGTAACAAAATATA AGGGGGAGGAAAGAAAAAGTCGGTCAAGAGGTAACTCTAAGTCGGCTATTCCTTTTTGGGAGGCGCTAACC ATAAACGGCATGGTCAACTTAGAGTTAGCTCAGGGAATTTAGGGAGTTATCTGCGACCACCTTTTAGGC 
Seqüências parciais do Transposon MATE de Aspergillus nidulans seqüências isoladas do primer F. As seqüências de nucleotídeos grifadas são os motivos “Spe", as regiões em negrito e itálico são segmentos da estrutura "stem-loop".

Linhagem MSE, seqüência com 836 nucleotídeos.

TATACGCNTCGCTTCCNTGGCGCACTCAACCCAAAGGACCTAATGGTNNACTTAGAGTTAGCTAAAATATA ATACTACTTGTCAGTAATGGACTTTTCCTCCTTTATTTACCTCAACTTCAATCTGCCAATAAGAAATAGTC TCAGACTAGTCACTGACTAGTTTGCAACTTGCTGCCACCATGTCTACAACTCTGCAAATTCCAGGTGCTAT TGACGTTCCAGAACAGGTACAAGACTTCATTTTTCTTACCTAGTTTGTGACTAGTTGCTAACTAGCAGCAG ATTGACAGAGTTATTCTTAGCAATCATCCAACACGTCCTCTAATCACATCTAAACTTGAATACTGCTATAT GTTACCTTACTATCCTGAATCTCATCAGAATAGCTATACCTATATTGTCCTACTTGATCCGAACCAGGTAA GGAGCAGGGAAGATAAGGGAAGACTTATTAAAAATATTTATTCTATAACTAATAAGGGACTAGTTGCTGAC TAGTCACAGACTCAATACCATGCTTGCCAGTTGGAGTGTTATAATACTCAATCACCCTATATTCAAGGCAG GGTTACTTAAATACAGTACTAGTATTCAGGCGTTCAAATATACTCTTATCTCTATCCTAACCTTAGAAATA TATACTATTACAAGGTTACAGAAGATGACTGGAACTATATCTGACAGGAGCAACAACTTATTAAAGAGACA GAAATAGATCCTAAAAAACAGAAAGCAATCTCATGAGNTACTAGTCTTTATTTAATTAGAGACTAATCAGG GACTAATTATATTTATATAGACNTTTCTTNGGTGTGCTTNATATATTNAAAAGAA

Linhagem A, seqüência com 728 nucleotídeos.

ANANNTTTNATANCGGNNNNCNCNNAGCGCACTAACCCAAAGGACTAAGGTCNCTTAGACGTTAGCTAAAA TATAATACTACTTGTCAGTAATGGACTTTTCCTCCTTTATTTACCTCAACTTCAATCTGCCAATAAGAAAT NGTCTCAGACTAGTCACTGACTAGTTTGCAACTTGCTGCCACCATGTCTACAACTCTGCAAATTCCAGGTG CTATTGACGTTCCAGAACAGGTACAAGACTTCATTTTTCTTACCTAGTTTGTGACTAGTTGCTAACTAGCA GCAGATTGACAGAGTTATTCTTAGCAATCATCCAACACGTCCTCTAATCACATCTAAACTTGAATACTGCT ATATGTTACCTTACTATCCTGAATCTCATCAGAATAGCTATACCTATATTGTCCTACTTGATCCGAACCAG GTAAGGAGCAGGGAAGATAAGGGAAGACTTATTAAAAATATTTATTCTATAACTAATAAGGGACTAGTTGC TGACTAGTCACAGACTCAATACCATGCTTGCCAGTTGGAGTGTTATAATACTCAATCACCCTATATTCAAG GCAGGGTTACTTAAATACAGTACTAGTATTCAGGCGTTCAAATATACTCTTATCTCTATCCTAACCTTAGA AATATATACTATTACAAGGTTACAGAACATGACTGGAACTATATCTGACAGGAGCAACAACTTATTANAGA GACAGAAATAGATCCTAAAAAACAGAAAGCATCTCTGAGNTAACTAGTCTTTATTTAATTANAGACTAATC A

Mutantes Sx1, seqüência com 829 nucleotídeos.

ANAGTNTNATANNCTCCCTANNAGCGCCTACCCAAAGGACTAGGGTCACTTAGAGTTAGCTAAAATATAAT ACTACTTGTCAGTAATGGACTTTTCCTCCTTTATTTACCTCAACTTCAATCTGCCAATAAGAAATAGTCTC AGACTAGTCACTGACTAGTTTGCAACTTGCTGCCACCATGTCTACAACTCTGCAAATTCCAGGTGCTATTG ACGTTCCAGAACAGGTACAAGACTTCATTTTTCTTACCTAGNTTTGTGACTAGTTGCTAACTAGCAGCAGA TTGACAGAGTTATTCTTAGCAATCATCCAACACGTCCTCTAATCACATCTAAACTTGAATACTGCTATATG TTACCTTACTATCCTGAATCTCATCAGAATAGCTATACCTATATTGTCCTACTTGATCCGAACCAGGTAAG GAGCAGGGAAGATAAGGGAAGACTTATTAAAAATATTTATTCTATAACTAATAAGGGACTAGTTGCTGACT AGTCACAGACTCAATACCATGCTTGCCAGTTGGAGTGTTATAATACTCAATCACCCTATATTCAAGGCAGG GTTACTTAAATACAGTACTAGTATTCAGGCGTTCAAATATACTCTTATCTCTATCCTAACCTTAGAAATAT ATACTATTACAAGGNTACAGAAGATGACTGGAACTATATCTGACAGGAGCAACAACTTATTAANGAGACNG AANTAGATCCTANNAAACAGGAANGCAATCNCATGAGTAACTAGTCTTTATTTNATTANAGACTAATCANG GACTAATTATATTATATAGACNTTTCTNGGGGGNGCTTANATATTAA 
Mutante Sx7, seqüência com 828 nucleotídeos.

TAGAGCCAGCNNCNGGNGCACTAACCCAAAGGAGCCAATGGATNCTTAGAGTTAGCTAAAATATAATACTA CTTGTCAGTAATGGACTTTTCCTCCTTTATTTACCTCAACTTCAATCTGCCAATAAGAAATAGTCTCAGAC TAGTCACTGACTAGTTTGCAACTTGCTGCCACCATGTCTACAACTCTGCAAATTCCAGGTGCTATTGACGT TCCAGAACAGGTACAAGACTTCATTTTTCTTACCTAGTTTGTGACTAGTTGCTAACTAGCAGCAGATTGAC AGAGTTATTCTTAGCAATCATCCAACACGTCCTCTAATCACATCTAAACTTGAATACTGCTATATGTTACC TTACTATCCTGAATCTCATCAGAATAGCTATACCTATATTGTCCTACTTGATCCGAACCAGGTAAGGAGCA GGGAAGATAAGGGAAGACTTATTAAAAATATTTATTCTATAACTAATAAGGGACTAGTTGCTGACTAGTCA CAGACTCAATACCATGCTTGCCAGTTGGAGTGTTATAATACTCAATCACCCTATATTCAAGGCAGGGGTTA CTTAAATACAGTACTAGTATTCAGGCGTTCAAATATACTCTTATCTCTATCCTAACCTTAGAAATATATAC TATTACANGGTTACAGAAGATGACTGGAACTATATCTGACAGGAGCAACAACTTATTAAGAGACAGAAATA GATCCTANNAANNGAAAGCAATCTCATGAGTACTAGTCTTATTTAATTAGAGACTANTCANGGACTANTNN ATTTATATAGACNTTTCTTNGGGGTGCTTTANATATTTANAGATATC

Mutante Sx9, seqüência com 821 nucleotídeos.

TTCTACGCTGCGCTNCCAAGCGCACTAACCCAAAGGACNTAATGGTCAACTTAGAGTTAGCTAAAATATAA TACTACTTGTCAGTAATGGACTTTTCCTCCTTTATTTACCTCAACTTCAATCTGCCAATAAGAAATAGTCT CAGACTAGTCACTGACTAGTTTGCAACTTGCTGCCACCATGTCTACAACTCTGCAAATTCCAGGTGCTATT GACGTTCCAGAACAGGTACAAGACTTCATTTTTCTTACCTAGTTTGTGACTAGTTGCTAACTAGCAGCAGA TTGACAGAGTTATTCTTAGCAATCATCCAACACGTCCTCTAATCACATCTAAACTTGAATACTGCTATATG TTACCTTACTATCCTGAATCTCATCAGAATAGCTATACCTATATTGTCCTACTTGATCCGAACCAGGTAAG GAGCAGGGAAGATAAGGGAAGACTTATTAAAAATATTTATTCTATAACTAATAAGGGACTAGTTGCTGANC TAGTCACAGACTCAATACCATGCTTGCCAGTTGGAGTGTTATAATACTCAATCACCCTATATTCAAGGCAG GGTTACTTAAATACAGTACTAGTATTCAGGCGTTCAAATATACTCTTATCTCTATCCTAACCTTAGAAATA TATACTATTACAAGGTTACAGAAGATGACTGGAACTATATCTGACAGGAGCAACAACTTATTAAAGAGACA GAAATAGATCCTANAAAACAGAAAGCATCTCATGAGTACTAGTCTTTATTNATTAGAGACTAATCAGGACT ANTATATTTATATANACATTTCTTNGGTGTGCNTTATNTT

Mutante Sx10, seqüência com 837 nucleotídeos.

CNNNNTTNNNNTNGATCACACCNCCCNCGGCNCGTAACCCAAAGGACCTAANGGGTCGTTCTTAGAGTTAG CTAAAATATAATACTACTTGTCAGTAATGGACTTTTCCTCCTTTATTTACCTCAACTTCAATCTGCCAATA AGAAATAGTCTCAGACTAGTCACTGACTAGNTTTGCAACTTGNCTGCCACCATGTCTACAACTCTGCAAAT TCCAGGTGCTATTGACGTTCCAGAACAGGTACAAGACTTCATTTTTCTTACCTAGTTTGTGACTAGTTGCT AACTAGCAGCAGATTGACAGAGTTATTCTTAGCAATCATCCAACACGTCCTCTAATCACATCTAAACTTGA ATACTGCTATATGTTACCTTACTATCCTGAATCTCATCAGAATAGCTATACCTATATTGTCCTACTTGATC CGAACCAGGTAAGGAGCAGGGAAGATAAGGGAAGACTTATTAAAAATATTTATTCTATAACTAATAAGGGA CTAGTTGCTGACTAGTCACAGACTCAATACCATGCTTGCCAGTTGGAGTGTTATAATACTCAATCACCC $\overline{T A}$ TATTCAAGGCAGGGTTACTTAAATACAGTACTAGTATTCAGGCGTTCAAATATACTCTTATCTCTATCCTA ACCTTAGAAATATATACTATTACAAGGTTACAGAAGATGACTGGAACTATATCTGACAGGAGCAACAACTT ATTAAAGAGACAGAAATAGATCCTANAAAACAGAAAGCATCTCATGAGTAACTAGTCTTATTTAATTAGAN ACTATCAGGACTANTATATTNTATANACATTTCTTNGGNGTGCTTATATATTNAAA

Mutante Sx13, seqüência com 848 nucleotídeos.

ANNNNCTTNTANGCTGCGCTTNNNAGCGCACTAACCCAAAGGACNTAATGGTCAACTTAGAGTTAGCTAAA ATATAATACTACTTGTCAGTAATGGACTTTTCCTCCTTTATTTACCTCAACTTCAATCTGCCAATAAGAAA TAGTCTCAGACTAGTCACTGACTAGTTTGCAACTTGCTGCCACCATGTCTACAACTCTGCAAATTCCAGGT GCTATTGACGTTCCAGAACAGGTACAAGACTTCATTTTTCTTACCTAGTTTGTGACTAGTTGCTAACTAGC AGCAGATTGACAGAGTTATTCTTAGCAATCATCCAACACGTCCTCTAATCACATCTAAACTTGAATACTGC TATATGTTACCTTACTATCCTGAATCTCATCAGAATAGCTATACCTATATTGTCCTACTTGATCCGAACCA GGTAAGGAGCAGGGAAGATAAGGGAAGACTTATTAAAAATATTTATTCTATAACTAATAAGGGACTAGTTG 
CTGANCTAGTCACAGACTCAATACCATGCTTGCCAGTTGGAGTGTTATAATACTCAATCACCCTATATTCA AGGCAGGGTTACTTAAATACAGTACTAGTATTCAGGCGTTCAAATATACTCTTATCTCTATCCTAACCTTA GAAATATATACTATTACAAGGGTTACAGAAGATGACTGGAACTATATCTGACAGGAGCAACAACTTATTAA AGAGACAGAAATAGATCCTNNAAAACAGAAAGCAATCTCATGAGTAACTAGTCTTTATTNATTAGAGACTA ATCANGGACTANTNTATTATATAGACATTTCTTNGGGGGGCTTTATATATTNANNAGATNCANNCTG

Mutante Sx14, seqüência com 710 nucleotídeos.

ANNTCTGNNCACTCNNCNTNNTCGCACTAACCCAAAGGACTTCGGGNTACTTANAGTTAGCTAAAATATAN CTACTACTTGNTCAGTAATGGACTTTTCCTCCTTTATTTACCTCAACTTCAATCTGCCCATAAGAAATAGT CTCAGTCTAGTCACTGACTNGTTTGCAACTTGCTGCCACCATGTCTACAACTCTGCAAATTCCAGGTGCTA TTGACGTTCCAGAACAGGTACAAGACTTCATTTTTCTTACCTAGTTTGTGACTAGTTGCTAACTAGCAGCA GATTGACAGAGTTATTCTTAGCAATCATCCAACACGTCCTCTAATCACATCTAAACTTGAATACTGCTATA TGTTACCTTACTATCCTGAATCTCATCAGAATAGCTATACCTATATTGTCCTACTTGATCCGAACCAGGTA AGGAGCAGGGNAAGATAAGGGAAGACTTATTAAAAATATTTATTCTATAACTAATAAGGGACTAGTTGCTG ACTAGTCACAGACTCAATACCATGCTTGCCAGTTGGAGTGTTATAATACTCAATCACCCTATATTCAAGG $\bar{G}$ CAGGGTTACTTANATACAGTACTAGTATTCAGGCGTTCAAATATACTCTTATCTCTATCCTAACCTTANAA ATATATACTATTACAAGGNTACANAANATGACTGGAACTATATCTGACAGGAGCNACANNTTATTAAGAGA

Mutante Sx15, seqüência com 710 nucleotídeos.

AAAGTCTATTCNCTCANNNGNNTAGCGCCTNNCCAAAGGACCTAAGGNTNNCTTAGAGTTAGCTAAAATAT AATACTACTTGTCAGTAATGGACTTTTCCTCCTTTATTTACCTCAACTTCAATCTGCCAATAAGAAATAGT CTCAGACTAGTCACTGACTAGTTTGCAACTTGCTGCCACCATGTCTACAACTCTGCAAATTCCAGGTGCTA TTGACGTTCCAGAACAGGTACAAGACTTCATTTTTCTTACCTAGNTTTGTGACTAGTTGCTAACTAGCAGC AGATTGACAGAGTTATTCTTAGCAATCATCCAACACGTCCTCTAATCACATCTAAACTTGAATACTGCTAT ATGTTACCTTACTATCCTGAATCTCATCAGAATAGCTATACCTATATTGTCCTACTTGATCCGAACCAGGT AAGGAGCAGGGAAGATAAGGGAAGACTTATTAAAAATATTTATTCTATAACTAATAAGGGACTAGTTGCTG ACTAGTTCACAGACTCAATACCATGGCTTGCCAGTTGGAGTGTTATAATACTCAATCACCCTATATTCAAN GGCAGGGTTACTTAAATACAGTACTAGTATTCAGGGCGTTNCAGATATACTCTTATCTCTATCCTAACCTT AGGAAATATATACTATTACAAGGTTACAGGAAGATGACTGGAACTATATCTTGACAGGGAGGNACNACCTT

Mutante Sx18, seqüência com 822 nucleotídeos.

GNNTCGNNNTTGTNTTTACCNTCCNNCCNGNNTTNGTAANTCTAAAGGTCCCCAGCGGGCCGCNNTTANAG TTAGCTAAAATATAATACTACTTGTCAGTAATGGACNTTTCCTCCTTTATTTACCTCAACTTCAATCTGCC AATAAGAAATAGTCTCAGACTAGTCACTGACTAGNTTTGCAACTTGCTGCCACCATGTCTACAACTCTGCA AATTCCAGGTGCTATTGACGTTCCAGAACAGGTACAAGACTTCATTTTTCTTACCTAGNTTTGTGACTAGT TGCTAACTAGCAGCAGATTGACAGAGTTATTCTTAGCAATCATCCAACACGTCCTCTAATCACATCTAAAC TTGAATACTGCTATATGTTACCTTACTATCCTGAATCTCATCAGAATAGCTATACCTATATTGTCCTACTT GATCCGAACCAGGTAAGGAGCAGGGAAGATAAGGGAAGACTTATTAAAAATATTTATTCTATAACTAATAA GGGACTAGTTGCTGACCTAGTCACAGACTCAATACCATGCTTGCCAGTTGGAGTGTTATAATACTCAATCA CCCTATATTCAAGGCAGGGTTACTTAAATACAGTACTAGTATTCAGGCGTTCAAATATACTCTTATCTCTA TCCTAACCTTAGAAATATATACTATTACAAGGTTACAGAAGATGACTGGAACTATATCTGACAGGAGCAAC AACTTATTANAGAGACAGAAATANATCCTANAAAACAGAAAGCAATCTCATGAGTAACTAGTCTTTATTTA NTTANAGACTAATCANGGACTAATTATATTTATATANACAT 
Mutante Sx19, seqüência com 618 nucleotídeos.

TAATACTACTTGTCAGTAATGGACNTTTCNTCTTTTATTTACCTCAACTTCAATCTGCCAATAAGAAATAG TCTCAGACTAGTCACTGACTAGNTTTGCAACTTGNCTGCCACCATGTCTACAACTCTGCAAATTCCAGGTG CTATTGACGTTCCAGAACAGGTACAAGACTTCATTTTTCTTACCTAGNTTTGTGACTAGTTGCTAACTAGC AGCAGATTGACAGAGTTATTCTTAGCAATCATCCAACACGTCCTCTAATCACATCTAAACTTGAATACTGC TATATGTTACCTTACTATCCTGAATCTCATCAGAATAGCTATACCTATATTGTCCTACTTGATCCGAACCA GGTAAGGAGCAGGGAAGATAAGGGAAGACTTATTAAAAATATTTATTCTATAACTAATAAGGGACTAGTTG CTGACTAGTCACAGACTCAATACCATGCTTGCCAGTTGGAGTGTTATAATACTCAATCACCCTATATTCAA GGCAGGGTTACTTAAATACAGTACTANTATTCACGCGTTCAAATATACTCTTATCTCTATCCTAACCTTAN AAATATATACTATTACAAGGTTACANAANATGANTGGAACTATATCTGAN

Mutante Sx23, seqüência com 821 nucleotídeos.

ATCCNCCTCGGTANGACAGCAATAACCCAAAGGACCAAGGNNTTCTTAGAGTTAGCTAAAATNTAATACTA CTTGTCAGTAATGGACCTTTCNTCCTTTATTTACCTCAACTTCAATCTGCCAATAAGAAATAGTCTCAGAC TAGTCACTGACTAGTTNGCAACTTGCTGCCACCATGTCTACAACTCTGCAAATTCCAGGTGCTATTGACGT TCCAGAACAGGTACAAGACTTCATTTTTCTTACCTAGTTTGTGACTAGTTGCTAACTAGCAGCAGATTGAC AGAGTTATTCTTNNCAATCATCCAACACGTCCTCTAATCACATCTAAACTTGAATACTGCTATATGTTACC TTACTATCCTGAATCTCATCAGAATAGCTATACCTATATTGTCCTACTTGATCCGAACCAGGTAAGGAGCA GGGAAGATAAGGGAAGACTTATTAAAAATATTTATTCTATAACTAATAAGGGACTAGTTGCTGACTAGTCA

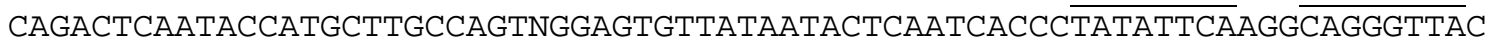
TTAAATACAGTACTAGTATTCAGGGCGTTCAAATATACTCTTATCTCTATCCTAACCTTANAAATATATAC TATTACAAGGTTACAGAANATGACTGGAACTATATCTGACAGGAGCAACANCTTATTNAAGAGACNGAAAT AGATCCTNNNAAACAGAAAGCATCTCNTGAGTANCANNNTTTATTTANTTAGAGACTATCNNGGACTANTT TATNTTNTAGACATNTCTTGGGGGTGCTTANATNTTAANA 


\section{ANEXO E}

Análise de Similaridade (\%) das seqüências isoladas. Análise foi realizada pelo site http://www.ncbi.nlm.nih.gov/BLAST/. Na tabela encontram-se os códigos do NCBI para os genes e elementos de transposons que apresentaram maior similaridade com as seqüências deste trabalho.

\begin{tabular}{|c|c|c|c|c|c|c|c|}
\hline \multirow{2}{*}{$\begin{array}{l}\text { Linhagens } \\
\text { analisadas }\end{array}$} & \multicolumn{7}{|c|}{ Similaridade das seqüências analisadas (\%) } \\
\hline & $\begin{array}{c}b r l \\
25858\end{array}$ & $\begin{array}{c}\text { niaD } \\
\mathrm{M} 58291\end{array}$ & $\begin{array}{l}\text { MATE 1A } \\
\text { BK001593 }\end{array}$ & $\begin{array}{l}\text { MATE 1B } \\
\text { BK001594 }\end{array}$ & $\begin{array}{l}\text { MATE } 4 \\
\text { BK } 01595\end{array}$ & $\begin{array}{l}\text { MATE } 5 \\
\text { BK } 001596\end{array}$ & $\begin{array}{l}\text { MATE } 9 \\
\text { BK } 001592\end{array}$ \\
\hline V5 & 100 & - & - & - & - & - & - \\
\hline MSE & - & 99 & - & - & - & - & - \\
\hline Sx11 & - & 99 & - & - & - & - & - \\
\hline $\mathrm{Sx} 12$ & - & 99 & - & - & - & - & - \\
\hline Sx 13 & - & 99 & - & - & - & - & - \\
\hline Sx 16 & - & 97 & - & - & - & - & - \\
\hline MSE & - & - & 94 & 95 & 95 & 99 & 95 \\
\hline A & - & - & 94 & 94 & 85 & 98 & 94 \\
\hline Sx1 & - & - & 93 & 93 & 94 & 97 & 93 \\
\hline $\mathrm{Sx} 7$ & - & - & 93 & 93 & 94 & 97 & 93 \\
\hline Sx9 & - & - & 94 & 94 & 95 & 98 & 94 \\
\hline $\mathrm{Sx} 10$ & - & - & 94 & 94 & 95 & 99 & 94 \\
\hline $\mathrm{Sx} 13$ & - & - & 94 & 94 & 95 & 98 & 94 \\
\hline $\mathrm{Sx} 14$ & - & - & 92 & 92 & 93 & 96 & 92 \\
\hline $\mathrm{Sx} 15$ & - & - & 94 & 94 & 95 & 98 & 94 \\
\hline $\mathrm{Sx} 17$ & - & - & 91 & 91 & 93 & 94 & 91 \\
\hline Sx 18 & - & - & 93 & 94 & 94 & 98 & 94 \\
\hline Sx19 & - & - & 93 & 93 & 93 & 97 & 93 \\
\hline $\mathrm{Sx} 23$ & - & - & 93 & 93 & 94 & 96 & 93 \\
\hline
\end{tabular}




\section{REFERÊNCIAS BIBIOGRÁFICAS}

ADAMS, T.H.; BOYLAN, M.T.; TIMBERLAKE, W.E. brlA is necessary and sufficient to direct conidiophore development in Aspergillus nidulans. Gene, v.54, p.353-362, 1988.

ADAMS, T.H.; DEISING, H.; TIMBERLAKE, W.E. brlA requires both zinc finger to induce development. Molecular Cellular Biology, v.10, p.1815-1817, 1990.

ADAMS, T.H.; WIESER, J.K.; YU, J.H. Asexual sporulation in Aspergillus nidulans. Microbiology and Molecular Biology Reviews, v.62, p.35-54, 1998.

ALEKSENKO, A.; CLUTTERBUCK, A.J. The plasmid replicator AMA1 in Aspergillus nidulans is an inverted duplication of a low-copy-number dispersed genomic repeat. Molecular Microbiology, v.19, p.565-574, 1996.

ALEKSENKO, A.; CLUTTERBUCK; A.J. Autonomous plasmid replication in Aspergillus nidulans: AMA1 e MATE elements. Fungal Genetics and Biology, v.21, p.373-387, 1997.

AMUTAN, M.; NYYSSÖNEN, E.; STUBBS, J.; DIAZ-TORRES, M.R.; DUNNCOLEMAN. N. Identification and cloning of a mobile transposon from Aspergillus niger var. awamori. Current Genetics, v.29, p.468-473, 1996.

ANAYA, P.; RONCERO, M.I. skippy, a retrotransposn from the fungal plant pathogen Fusarium oxysporum. Molecular and General Genetics, v.249, p.637-674, 1995.

ANAYA, P.; EVANS, S.C.; DAI, C.P. Isolation of the Aspergillus nidulans sudD gene and its human homologue. Gene, v.211, p.323-329, 1998.

APIRION, D. A general system for the automatic selection of auxotrophs from prototrophic and vice versa in micro-organisms. Nature, v.195, p.959-961, 1962.

AXELROD, D.E. Kinetics of differentiation of conidiophores and conidia by colonies of Aspergillus nidulans. Journal of General Microbiology, v.73, p.181-84, 1972

AXELROD, D.E.; GEALT, M.; PASTUSHOK, M. Gene control of developmental competence in Aspergillus nidulans. Developmental Biology, v34, p.9-15, 1973. 
AZEVEDO, J.L.; ROPER, J.A. Mitotic non-conformity in Aspergillus nidulans: successive and transposable genetic change. Genetical Research, v.16, p.79-93, 1970 .

AZEVEDO, J.L.; OLIVEIRA, A.; ROCHA CAMPOS, A.J. Replicador multifio para transferência de esporos de fungos filamentosos. Summa Phytopathologia, v.2, p.237-241, 1976.

BAINBRIDGE, B.W.; ROPER, J.A. Observations on the effects of a chromosome duplication in Aspergillus nidulans. Journal of General Microbiology, v.42, p.417424, 1966.

BALL, C. Chromosome instability related to gene suppression in Aspergillus nidulans. Genetical Research, v.10, p.173-183, 1975.

BALL, C.; AZEVEDO, J.L. A "fluffy" mutant in Aspergillus nidulans. Aspergillus Newsletter, v.5, p.9, 1964.

BECKWITH, S.M.; MORRIS, N.R. Cytoplasmatic dynein is missing at the tip in nudG, a nuclear migration mutant in Aspergillus nidulans. Molecular Biology of the Cell (Suppl.), v.6, p.24-24, 1995.

BERGEN, L.G.; MORRIS, N.R. Kinetics of nuclear division cycle of Aspergillus nidulans. Journal of Bacteriology, v.156, p.155-160, 1983.

BIAGI, C.M.R. Mutantes morfológicos induzidos por 8-metoxipsoraleina e luz ultravioleta em Aspergillus nidulans. Piracicaba, 1977. 150 p. (Mestrado) Escola Superior de Agricultura "Luiz de Queiroz" - Universidade de São Paulo.

BIBBINS, M.; CUMMINGS, N.J.; CONNERTON, I.F. DAB1: a degenerate retrotransposon-like element from Neurospora crassa. Molecular and General Genetics, v.258, p.431-436, 1998.

BONATELLI, J.R.; AZEVEDO, J.L. Effects of ethidium bromide in diploid and duplication strains of Aspergillus nidulans. Experientia, v.33, p.331-312, 1977.

BOYLAN, M.T.; MIRABITO, P.M.; WILLET, C.E.; ZIMMERMAN, C.R.; TIMBERLAKE, W.E. Isolation and physical characterization of three essential conidiation gene from Aspergillus nidulans. Molecular and Cellular Biology, v.7, p.3113-3118, 1987.

BRODY, H.; CARBON, J. Electrophoretic karyotype of Aspergillus nidulans. Proceedings of the National Academy of Sciences USA, v.86, p.6260-6263, 1989. 
BULL, A.T. Chemical composition of wild-type and mutant Aspergillus nidulans cell wall. The nature of polysaccharide and melanin constituents. Journal of General Microbiology, v.63, p.75-94, 1970.

BUREAU, T.E.; WESSLER, S.R. Tourust: a large family of small inverted repeat elements frequently associated with maize genes. Plant Cell, v.4, p.1283-1294, 1992.

BUSBY, B.M.; MILLER, K.Y.; MILLER, B.L. Suppression and enhancement of the Aspergillus nidulans medusa mutation by altered dosage of the bristle and stunted genes. Genetics, v.143, p155-163, 1996.

BUTNICK, N.Z.; YAGER, L.N.; KURTZ, M.B.; CHAMPE, S.P. Genetic analysis of mutants of Aspergillus nidulans blocked at an early stage of sporulation. Journal of Bacteriology, v.160, p.541-545, 1984 b.

BUTNICK, N.Z.; YAGER, L.N.; HERMANN, T.E., KURTZ, M.B.; CHAMPE, S.P. Mutants of Aspergillus nidulans blocked at an early stage of sporulation secrete an unsual metabolite. Journal of Bacteriology, v.160, p.533-345, 1984 a.

CAMBARERI, E.B.; HELBER, J.; KINSEY, J.A. Tad1, an LINE-like element of Neurospora crassa. Molecular and General Genetics, v.242, p.658-665, 1994.

CAMBARERI, E.B.; JENSEN, B.C.; SCHABTACH, E.; SELKER, E.U. Repeatinduced G-C to A-T mutations in Neurospora. Science, v.244, p.1571-1575, 1989.

CASTRO-PRADO, M.A.A.; ROCHA, C.L.S. Cytological and Genetic characterization of a conidiogenesis mutants of Aspergillus nidulans. Cytologia, v. 63, p. 99-106, 1998.

CHALVET, P.; GASPERI, C.; KAPER, F.; LANGIN, T.; DABOUSSI, M.J. Hop, an active Mutator-like element in the genome of the fungus Fusarium oxysporum. Molecular and Biology Evolution, v.20, p.1362-1345, 2003.

CHAMPE, S.P.; NAGLE, D.L.; YAGER, I. Sexual Sporulation. In: MARTINELLI, S.D.; KINGHORN, J.R. (Ed.) Aspergillus 50 years on. 1994.vol. 29, cap. 17, p.429458.

CHAMPE, S.P.; KURTZ, M; YAGER, I.; BUTNICK, N.; AXELROD, D. Spore formation in Aspergillus nidulans: competence and other developmental processes. In.: HOHL, H.R.; TURIN, G. (Ed.). The Fungal Spore Morphogenetic Control. New York. Academic Press; 1981. p.255-276.

CLUTTERBUCK, J.A. A mutational analysis of conidial development in Aspergillus nidulans. Genetics, v.63, p.317-327, 1969. 
CLUTTERBUCK, J.A. A variegated position effect in Aspergillus nidulans. Genetical Research, v.16, p.303-311, 1970a.

CLUTTERBUCK, J.A. Absence of laccase from yellow-spored mutants of Aspergillus nidulans. Journal of General Microbiology, v.70, p.423-435, 1972.

CLUTTERBUCK, J.A. MATE transposable elements in Aspergillus nidulans evidence of repeat-induced point mutation. Fungal Genetics and Biology, v.41, p.308-316, 2004.

CLUTTERBUCK, J.A. Mutants of Aspergillus nidulans deficient in nuclear migration during hyphal growth and conidiation. Microbiology, v.140, p.1169-1174, 1994.

CLUTTERBUCK, J.A. Synchronous nuclear division and septation in Aspergillus nidulans. Journal of General Microbiology, v.60, p.133-135, 1970 b.

CLUTTERBUCK, J.A. The genetics of conidiation pigmentation in Aspergillus nidulans. Journal of General Microbiology, v.136, p.1731-1738, 1990.

CLUTTERBUCK, J.A. The validity of the Aspergillus nidulans linkage Map. Fungal Genetics and Biology, v.21, p.267-277, 1997.

CLUTTERBUCK, J.A.; SPATHAS, D.H. Genetic and environmental modification of gene expression in the brl A12 variegated position effect mutants of Aspergillus nidulans. Genetical Research, v.43, p.123-138, 1984.

COGONI, C. Homology-dependent gene silencing mechanisms in fungi. Annual Review Microbiology, v.55, p.381-406, 2001.

COMFORT, N.C. From controlling elements to transposons: Barbara McClintock and the Nobel Prize. Endeavour, v.25, p.127-130, 2001.

COVE, D.J. Chlorate toxicity in Aspergillus nidulans. Studies of mutants altered in nitrate assimilation. Molecular and General Genetics, v.146, p.147-59, 1976a.

COVE, D.J. Chlorate toxicity in Aspergillus nidulans: the selection and characterisation of chlorate resistant mutants. Heredity, v.36, p.191-203, $1976 \mathrm{~b}$.

CUADROS, S.C.; BRITO, A.G.; MARTINEZ-ROSSI, N.M.; ROSSI, A. The Aspergillus nidulans phsB4 mutation alters colonial and development of the moul at acid $\mathrm{pH}$. Journal of Microbiology and Biotechnology, v.17, p.779-782, 2001.

DABOUSSI, M.J. Fungal transposable elements: generations of diversity and genetic tools. Journal of Genetics, v.75, p.325-339, 1996. 
DABOUSSI, M.J.; CAPY, P. Transposable Elements in filamentous fungi. Annual Review of Microbiology, v.57,p. 275-299, 2003.

DABOUSSI, M.J.; LAGIN, T. Transposable elements in the fungal plant pathologic Fusarium oxysporum. Genetica, v.93, p.49-59, 1994.

DABOUSSI, M.J.; LAGIN, T., BRYGOO, Y. Fot1, a new family of fungal transposable elements. Molecular and General Genetics, v.232, p.12-16, 1992.

DABOUSSI, M.J.; DAVIÈRE, J.M.; GRAZIANI, S.; LAGIN, T. Evolution of the Fot1 transposon in the genus Fusarium: discontinuous distribution end epigenetic inactivation. Molecular Biology Evolution, v. 19, p. 510-520, 2002.

DEKKER, J.; DAVIDSE, L.C. Acquired resistence to benzimidazole derivatives. Enviromental Quality and Safe, Supplement, v.3, p.410-413, 1975.

DENISON, S.; KÄFER, E.; MAY, G. Mitotic in the bimD gene of Aspergillus nidulans confers a coniditional mitotic block and sensitivity to DNA damaging agents. Genetics, v.134, p.1085-1096, 1993.

DeVRIES, L.M.; MOUSLI, A.; WURMSER, A.; FARQUAR, M. Gaip, a protein that specifically interacts with the trimeric $G$ protein Gai3, is a member of a protein family with a highly conserved core domain. Proceedings of the National Academy of Sciences USA, v.92, p.11926-11932, 1995.

DOBINSON, K.F.; HARRIS, R.E.; HAMER, J.E. Grasshopper, a long terminal repeat (LTR) retroelement in the phytopathogenic fungus Magnaporthe grisea. Molecular Plant-Microbe Interactions, v.6, p.114-126, 1993.

DOONAN, J.H. Cell division in Aspergillus. Journal Cell Science, v.103, p.599-611, 1992.

DOONAN, J.H.; MACKINTOSH, C.; OSMANI, S.; COHEN, O.; BAI, G. A cDNA encoding rabbit muscle protein phosphatase 1 alpha complements the Aspergillus nidulans cell cycle mutation, bimG11. Journal of Biological Chemistry, v.266, p.18889-18894, 1991.

DÖRING, H.P.; STARLINGER, P. Molecular genetics of transposable elements in plants. Annual Review Genetics, v.20, p.175-200, 1986.

DOSHI, P.; BOSSIE, C.A.; DOONAN, J.H.; MAY, G.S.; MORRIS, N.R. Two Ktubulin genes of Aspergillus nidulans encode divergent proteins. Molecular and General Genetics, v.225, p.129-141, 1991. 
DUTTON, J.R.; JOHNS, S.; MILLER, B. stuA is a sequence-specific transcription factor that regulation developmental complexity in Aspergillus nidulans. The EMBO Journal, v.16, p.5710-5721, 1997.

DYNESEN, J.; NIELSEN, J. Branching is coordinated with mitoses in growing hyphae of Aspergillus nidulans. Fungal Genetics and Biology, v.40, p.15-24, 2003.

EIDAM, E. Zur Kenntniss der entwicklung ber den Ascomyceten III. Sterigmatocystis nidulans n. sp. Cohn Bieth Biol, v.3, p.392-411, 1883.

ENOS, A.P.; MORRIS, N.R. Mutation of a gene that encodes a kinesin-like protein blocks nuclear division in Aspergillus nidulans. Cell, v.97, p.169-184, 1990.

EVANS, R.M.; HOLLENBERG, S.M. Zinc finger: gilt by association. Cell, v.52, p.1-3, 1988.

FARMAN, M.L.; TAURA, S.; LEONG, S.A. The Magnaporthe grisea DNA fingerprinting probe MGR586 contains the 3' end of an inverted repeat transposon. Molecular and General Genetics, v.251, p.675-681, 1996a.

FARMAN, M.L.; TOS, Y.; NITTA, N.; LEONG, S.A. MAGGY, a retrotransposon in the genome of rice blast fungus, Magnaporthe grisea. Molecular and General Genetics, v.251, p.665-674, 1996 b.

FESCHOTTE, C.; WESLLER, S.R. Treasures in the attic: Rolling circle transposons discovered in eukaryotic genomes. Proceedings of the National Academy of Science, USA, v.98, p.8923-8924, 2001.

FESCHOTTE, C.; JIANG, N.; WESLLER, S.R. Plant transposable elements: where genetics meets genomics. National Review Genetics, v.3, p.329-336, 2002.

FIDDY, C.; TRINCI, A.P. Mitosis, septation, branching and the duplication cycle in Aspergillus nidulans. Journal of General Microbiology, v.97, p.169-184, 1976.

FINNEGAN, D.J. Transposable elements in eukaryotes. International Review in Cytology, v.93, p.281-326, 1985.

FISCHER, R. Nuclear movement in filamentous fungi. FEMS Microbiological Reviews, v.23, p.39-69, 1999.

FISCHER, R.; TIMBERLAKE, W.E. Aspergillus nidulans apsA (anucleate primary sterigmata) encodes a coiled-coil protein necessary for nuclear positioning and completion of asexual development. Journal of Cell Biology, v.128, p.485-498, 1995. 
FOREMAN, P.K.; DAVIS, R.W. CDP1, a novel Saccharomyces cerevisiae gene required for proper nuclear division and chromosome segregation. Genetics, v.144, p.1387-1397, 1996.

FREY, M.; STETTNER, C.; GIERL, A. A general method for gene isolation in tagging approaches: amplification of insertion mutagenised sites (AIMS). The Plant Journal, v.13, p.717-721, 1998.

GALAS, D.J.; CHANDLER, M. Bacterial insertion sequences. In.: BERG, D.E.; HOWE, M.M (Ed). Mobile DNA, Washington, D.C.: American Society for Microbiology. 1989. p.109-162.

GEMS, D.; JOHNSTONE, I.L.; CLUTTERBUCK, A.J. An autonomously replication plasmid transforms Aspergillus nidulans at high frequency. Gene, v.98, p.61-67, 1991.

GIANCOLI, A.C.H. Caracterização citológica e genética de linhagens de Aspergillus nidulans portadoras de duplicação cromossômica e do gene bncA1. Piracicaba, 2000. 103p. (Mestrado) - Escola Superior de Agricultura "Luiz de Queiroz" Universidade de São Paulo.

GIANCOLI, A.C.H.; PIZZIRANI-KLEINER, A.A. Conidiogenesis of deteriorated variant of the strain of Abnc of Aspergillus nidulans. Scientia Agricola, no prelo. Vol. 61, no. 4.

GIBSON, T.J.; HYVOËNEN, M.; MUSACCHIO, A.; SARASTE, M. PH domain: the first anniversary. Trends Biochemical Sciences, v.19, p.349-353, 1994.

GIERL, A.; SAEALER, H.; PETERSON, P.A. Maize transposable elements. Annual Review of Genetics, v.23, p.71-85, 1989.

GIMENO, C.J.; FINK, G.R. Induction of pseudohyphal growth by overexpression of PHD1, Saccharomyces cerevisiae gene related to transcriptional regulators of fungal development. Molecular of Cell Biology, v.14, p.2100-2112, 1994.

GIMENO, C.J.; LJUNDGAHL, P.; STYLES, C.A.; FINKS, G.R. Unipolar cell divisions in the yeast Saccharomyces cerevisiae lead to filamentous growth: regulation by starvation and Ras. Cell, v.68, p.1077-1090, 1992.

GLASS, N.L.; DONALDSON, G.C. Development of primer sets designed for use wuth PCR to amplify conserved genes from filamentous Ascomycetes. Applied and Environmental Microbiology, v.61, p.1323-1330, 1995. 
GLAYZER, D.C.; ROBERTS, I.N.; ARCHER, D.B.; OLIVER, R.P. The isolation of Ant1, a transposable element from Aspergillus niger. Molecular and General Genetics, v.249, p.432-438, 1995.

GOLDMAN, G.H.; MORRIS, N.R. Extragenic suppressors of a dynein mutation that blocks nuclear migration in Aspergillus nidulans. Genetics, v.139, p.1223-1232, 1995.

GOODAY, G.W. The hyphae tip. In: SMITH, J.E. Fungal Differentiation. A Contemporary Synthesis. New York: Dekker, 1983. p.315-356.

GRAIG, N.L.; GRAIGIE, R.; GELLERT, M.; LAMBOWITZ. A.M. Mobile DNA II, Washington, DC: ASM, 2002. p.1204.

GUEST, M.G.; XIAORONG, L.; MOMANY, M. Aspergillus nidulans rhoA is involved in polar growth branching, and cell wall synthesis. Fungal Genetics and Biology, v.41, p.13-22, 2004.

HAMER, J.E.; FARRALL, L.; ORBACH, M.J.; VALENT, B.; CHUMLEY, F.C. Host species-specific conservation of a family of repeated DNA sequences in the genome of a fungus pathogen. Proceedings of the National Academy of Science USA, v.86, p.9981-9985, 1989.

HAMER, L. From genes to genomes: Sequencing of filamentous fungal genomes. Fungal Genetics and Biology, v.21, p.8-10, 1997.

HAN, S.; NAVARRO, J.; GREVE, R.A.; ADAMS, T.H. Translation repression of brlA expression prevents premature developmental in Aspergillus. The EMBO Journal, v.12, p.2439-2448, 1993.

HARRIS, S.D. Septum formation in Aspergillus nidulans. Current Opinion in Microbiology, v.4, p.736-739, 2001.

HARRIS, S.D. The duplication cycle in Aspergillus nidulans. Fungal Genetics and Biology, v.22, p.1-12, 1997a.

HARRIS, S.D.; HAMER, J.E. sepB: an Aspergillus nidulans gene involved in chromosome segregation and the initiation of cytokinesis. The EMBO Journal, v.14, p.5244-5257, 1995.

HARRIS, S.D.; HOFMANN, A.F. Tedford for hyphae morphogenesis in the filamentous fungus Aspergillus nidulans. Genetics, v.151, p.1015-1025, 1999a.

HARRIS, S.D.; KRAUS, P. Regulation of septum formation in Aspergillus nidulans by a DNA damages checkpoint pathway. Genetics, v. 148, p. 1055-1567. 1998. 
HARRIS, S.D.; MORRELL, J.L.; HAMER, J.E. Identification and characterization of Aspergillus nidulans mutants defective in cytokinesis. Genetics, v.136, p.517-532, 1994.

HARRIS, S.D.; HAMER, L.; SHARPLESS, K.E.; HAMER, J.E. The Aspergillus nidulans sepA gene encodes an FH12 protein involved in cytokinesis and the maintenance of cellular polarity. The EMBO Journal, v.16, p.3474-3483, 1997b.

HARRIS, S.D.; HOFMANN, A.F.; TEDFORF, H.W.; LEE, M.P. Identification and characterization of gene required for hyphal morphogenesis in the filamentous fungus Aspergillus nidulans. Genetics, v.151, p.1015-1025, $1999 \mathrm{~b}$.

HARTWELL, L.H. Saccharomyces cerevisiae cell cycle. Bacteriology Reviews, v.38, p.164-198, 1974.

HARTWELL, L.H.; KASTAN, M.B. Cell cycle control and cancer. Science, v.266, p.1821-1828, 1994.

HASTIE, A.C. Benlate-induced instability of Aspergillus nidulans diploids. Nature, v.226, p.771, 1970.

HIROKAWA, N. Kinesin and dynein superfamily proteins and the mechanism of organelle transport. Science, v.279, p.519-526, 1998.

HOLMES, I. Transcendent Elements: Whole-genome transposon screens and open evolutionary questions. Genome Research, v.12, p.1152-1155, 2002.

HOLT, C.L.; MAY, G.S. An extragenic suppressor of the mitosis-defective bimD6 mutation of Aspergillus nidulans codes for a chromosome scaffold protein. Genetics, v.142, p.777-787, 1996.

HOLZBAUR, E.L.F.; VALLEE, R.B. Dyneins: Molecular Structure and Cellular Function. Annual Review and Cell Biology, v.10, p.339-372, 1994.

HUA-VAN, A.; LANGIN, T.; DABOUSSI, M.J. Evolucionary history of the impala transposon in Fusarium oxysporum. Molecular Biology Evolution, v.18, p.19591969, 2001.

HUA-VAN, A.; HÉRICOURT, F.; CAPY, M.J.; DABOUSSI, M.J.; LANGIN, T. Three highly divergent subfamilies of the impala transposable element coexist in the genome of the fungus Fusarium oxysporum. Molecular and General Genetics, v.259, p.354-362, 1998. 
IKEDA, K.I.; NAKAYASHIKI, H.; KATAOKA, T.; TAMBA, H.; HAHIMOTO, Y.; TOSA, Y.; MAYAMA, S. Repeat-induced point mutation (RIP) in Magnaporthe grisea: implications for its sexual cycle in the natural field context. Molecular Microbiology, v.45, p.1355-1364, 2002.

JOHNSTONE, I.L.; HUGHES, S.G.; CLUTTERBUCK, A.J. Cloning an Aspergillus nidulans developmental gene by transformation. The EMBO Journal, v.4, p.1307$1312,1985$.

JOHNSTONE，I.L.; MCCABE，P.C.; GREAVES，P.; GURR，S.J.; COLE，G.E.; BROW, M.A.; UNKLES, S.E.; CLUTTERBUCK, A.J.; KINGHORN, J.R.; INNIS, M.A. Isolation and characterization of the crnA-niiA-niaD gene cluster for nitrate assimilation in Aspergillus nidulans. Gene, v.90, p.181-192, 1990.

JULIEN, J.; POIRIER-HAMON, S.; BRYGOO, Y. Forest1, a reverse transcriptase-like sequence in the filamentous fungus Fusarium oxyporum. Nucleic Acids Research, v.20, p.3933-3937, 1992.

KACHROO, P.; LEONG, S.A.; CHATTOO, B. Mg-SINE: A short interspersed nuclear element from the rice blast fungus, Magnaporthe grisea. n, v.92, p.11125-11129, 1995.

KACHROO, P.; LEONG, S.A.; CHATTOO, B. Pot2, an inverted repeat transposon from the rice blast fungus Magnaporthe grisea. Molecular and General Genetics, v.245, p.339-348, 1994.

KÄFER, E. High frequency of spontaneous and induced somatic segregation in Aspergillus nidulans. Nature, v.186, p.619-620, 1960.

KÄFER, E. The process of spontaneous recombination on in vegetative e nuclei of Aspergillus nidulans. Genetics, v.46, p.1581-1509, 1961

KAMINSKYJ, S.G.W. Septum position is marked at the tip of Aspergillus nidulans hyphae. Fungal Genetics and Biology, v.31, p.105-113, 2000.

KAMINSKYJ, S.G.W.; HAMER, J.E. hyp loci controls cell pattern formation in the vegetative mycelium of Aspergillus nidulans. Genetics, v.148, p.669-680, 1998.

KANG, S. Organization and distribution pattern of MGLR-3, a novel retrotransposon in the rice blast fungus Magnaporthe grisea. Fungal Genetics and Biology, v.32, p.1119, 2001.

KAPITONOV, W.V.; JURKA, J. Rolling-circle transposons in eukaryotes. Proceedings of the National Academy of Science USA, v.98, p.8714-8719, 2001. 
KAROS, M.; FISCHER, R. Aspergillus nidulans hymA encodes an evolutionarily highly conserved and a highly expressed protein. Molecular and General Genetics, v.260, p.510-521, 1999.

KAROS, M.; FISCHER, R. hymA (hypha-like metulae), a new developmental mutant of Aspergillus nidulans. Microbiology, v.142, p.3211-3218, 1996.

KEMPKEN. F. Fungal transposons: from mobile elements towards molecular tools. Applied Microbiology Biotechnology, v.52, p.756-760, 1999.

KEMPKEN, F.; KÜCK, U. Evidence for circular transposition derivatives from the fungal hAT-transposon Restless. Current Genetics, v.34, p.200-203, 1998a.

KEMPKEN, F.; KÜCK, U. Restless, an active Ac-like transposon from the fungus Tolypocladium inflatum: structure, expression, and alternative RNA splicing. Molecular and Cell Biology, v.16, p.6563-6572, 1996.

KEMPKEN, F.; KÜCK, U. Tagging of a nitrogen pathway-specific regulator gene in Tolypocladium inflatum by the transposon Restless. Molecular and General Genetics, v.263, p.302-308, 2000.

KEMPKEN. F.; JACOBSEN, S.; KÜCK, U. Distribution of the fungal transposon Restless: full-length and truncated copies in closely related strains. Fungal Genetics Biology, v.25, p.110-118, 1998b.

KEMPKEN, F.; SCHREINER, C.; SCHÖRGENDORFER, K.; KÜCK, U. A unique repeated DNA sequence in the cyclosporin-producing strain of Tolypocladium inflatum (ATCC 34921). Experiential Mycologyst, v.19, p.305-313, 1995.

KIMURA, M.; YAMAGUCHI, I. Convergent transcription units and their promoters at both ends of Pot2, and inverted repeat transposon from the rice blast fungus. Journal of Biochemistry, v.124, p.268-273, 1998.

KINSEY, J.A.; HELBER, J. Isolation of a transposable element from Neurospora crassa. Proceeding of the National Academy of Science USA, v.86, p.1929-1933, 1989.

KIRK, K.E.; MORRIS, N. The tub-B alfa tubulin gene is essential for sexual development in Aspergillus nidulans. Genes and Development, v.5, p.2014-2023, 1991.

KORMANEC, J.; SCHAAFI-GERSTENSCHLAË, G.E.R.; ZIMMERMANN, R.K.; PERECKO, D.; KUËNTZEL, H. Nuclear migration in Saccharomyces cerevisiae is controlled by the highly repetitive $313 \mathrm{kDa}$ NUM1 protein. Molecular and General Genetics, v.230, p.277-287, 1991. 
KOSMIDOU, E.; LUNES, P.; DONAN, J.H. A type 2A phosphatase gene from Aspergillus nidulans is involved in hyphal morphogenesis. Current Genetics, v.39, p.25-34, 2001.

KRONSTAD, J.W.; STABEN, C. Mating types in filamentous fungi. Annual Review of Genetics, v.31, p.245-276, 1997.

KRUËGER, M.; FISCHER, R. Isolation of two aspA suppressor strains in Aspergillus nidulans. Genetics, v.144, p.533-540, 1996.

KUPFER, D.M.; REECE, A.; CLIFTON, S.W.; ROE, B.A.; PRADE, R.A. Multinucear Ascomycetous fungal genomes contain more than 8000 genes. Fungal Genetics and Biology, v.21, p.364-372, 1997.

LANGIN, T.; CAPY, P.; DABOUSSI, M.J. The transposable element impala, a fungal member of the Tc1-mariner superfamily. Molecular General Genetics, v.246, p.19$28,1995$.

LAW, D.J.; TIMBERLAKE, W.E. Developmental regulation of lacase level in Aspergillus nidulans. Journal of Bacteriology, v.144, p.509-517, 1980.

LEDBETTER, S.A. Microdeletions of chromosome $17 \mathrm{p} 13$ as a cause of isolated lissencephaly. American Journal of Human Genetics, v.50, p.182-189, 1992.

LEE, B.N.; ADAMS, T.H. Overexpression of flbA, an early regulator of Aspergillus asexual sporulation leads to activation of brlA and premature initiation of development. Molecular Microbiology, v.14, p.323-334, 1994a.

LEE, B.N.; ADAMS, T.H. The Aspergillus nidulans fluG gene is required for production of an extracelular developmental signal. Genes and Development, v.8, p.641-51, 1994b.

LEMMON, M.A.; FERGUSON, K.M.; SCHLESSINGER, J. PH domains: Diverse sequences with a common fold recruit signaling molecules to the cell surface. Cell, v.85, p.621-624, 1996.

LEVENTER, R.; PILZ, D.; MATSUMOTO, N.; LEDBETTER, D.; DOBYNS, W. Lissencephaly and subcortical band heterotopia: molecular basis and diagnosis. Molecular Medicine Today, v.6, p.277-284, 2000

LEW, D.J.; KORNBLUTH, S. Regulatory roles of cyclin dependent kinase phosphorylation in cell cycle control. Current Opinion in Cell Biology, v.8, p.795804, 1996. 
LHOAS, P. Mitotic haploidization by treatments of Aspergillus niger with $\rho$ fluorfenilalanina. Nature, v.190, p.744, 1961.

LIEBER, M.M. The effects of temperature on genetic instability in Aspergillus nidulans. Mutation Research, v.34, p.93-122, 1976.

LIES, C.M.; CHENG, J.; JAMES, S. W.; MORRIS, N.R.; O'CONNELL, M.J. BIMAAPC3, a component of the Aspergillus anaphase promoting complex / cyclosome, is required for a $\mathrm{G} 2$ checkpoint blocking entry into mitosis in absence of NIMA function. Journal of Cell Science, v.111, p.1453-1465, 1998.

MAHILLON, J.; CHANDLER, M. Insertion Sequences. Microbiology and Molecular Biology Reviews, v.62, p.725-774, 1998.

MARHOUL, J.F.; ADAMS, T.H. Aspergillus fabM encodes an essential product that is related to poly(A)-binding proteins and activates development when overexpressed. Genetics, v.144, p.1463-1470, 1996.

MARSHALL, M.A.; TIMBERLAKE, W.E. Aspergillus nidulans wetA regulates sporespecific gene expression. Molecular and Cellular Biology, v.11, p.55-62, 1991.

MARTINELLI, S.D. Conidiation of Aspergillus nidulans in submerged culture. Heredity, v.29, p.130, 1976.

MARTINELLI, S.D.; CLUTTERBUCK, A.J. Quantitative survey conidiation mutants in Aspergillus nidulans. Journal of General Microbiology, v.69, p.261-268, 1971.

MATSUMOTO, N.; LEDBETTER, D.H. Molecular cloning and characterization of the human NUDC gene. Human Genetics, v.104, p.498-504, 1999.

MAURER, P.; RÉJASSE, A.; CAPY, P.; LANGIN, T.; RIBA, G. Isolation of the transposable element hupfer from the entomopathogenic fungus Beauveria bassiana by insertion mutagenesis of the nitrate reductase structural gene. Molecular and General Genetics, v.256, p.195-202, 1997.

McCLINTOCK, B. Chromosome organization and genetic expression. Cold Spring Harbor Symposium Quantitative Biology, v.16, p.13-19, 1951 b.

McCLINTOCK, B. Mutable loci in maize. Carnegie Institute Washington Yearb, v.51, p.212-219, 1951a.

McCLINTOCK, B. Some parallels between gene control systems in maize and in bacteria. American Naturalist, v.95, p.265-277, 1961. 
McCLINTOCK, B. Suppresor-Mutator system of control of gene action in maize. Carnegie Institute Washington Yearb, v.57, p.415-429, 1958.

McCLINTOCK, B. The origin and behavior of mutable loci in maize. Proceedings of the National Academy of Science USA, v.36, p.344, 1950.

McCULLY, K.S.; FORBES, E. The use of p-fluorphenilalanine with "master" strain of Aspergillus nidulans form assigning gene of to linkage groups. Genetical Research, v.6, p.352-359, 1965.

McGOLDRICK, C.A.; GRUVER, C.; MAY, G.S. myoA of Aspergillus nidulans encodes an essential myosin I required for secretion and polarized growth. Journal of Cell Biology, v.128, p.577-587, 1995.

MELIN, P.; SCHNÜRER, J.; WAGNER, E.G.H. Characterization of phiA, a gene essential for phialide development in Aspergillus nidulans. Fungal Genetics and Biology, v.40, p.187-194, 2003.

MENDIOLA, M.V.; BERNALES, I.; La CRUZ, F. Differential roles of the transposon termini in IS91 transposition. Proceedings of the National Academy of Science USA, v.91. p.1922-1926, 1994.

MENEZES, E.M. Analise genética de variantes deteriorados e suas reversões em Aspergillus nidulans. Piracicaba, 1974. 114 p. (Mestrado) - Escola Superior de Agricultura "Luiz de Queiroz" - Universidade de São Paulo.

MIGHELI, Q.; LAUGE, R.; DAVIERE, J.M.; GERLINGER, C.; KAPER, F.; LANGIN, T.; DABOUSSI, M.J. Transposition of the autonomous Fot 1 element in the fialmentous fungus Fusarium oxysporum. Genetics, v.151, p.1005-1013, 1999.

MILLER, B.L. The developmental genetics of asexual reproduction in Aspergillus nidulans. Developmental Biology, v.1, p.207-219, 1990.

MILLER, B.L. The medA gene of Aspergillus nidulans. Journal of Cellular Biochemistry, v.17, p.44, 1993.

MILLER, K.Y.; WU, J.; MILLER, B.L. Stu A is required for cell pattern formation in Aspergillus. Genes and Development, v.6, p.1770-1782, 1992.

MILLER, B.L.; MILLER, K.Y.; TIMBERLAKE, W.E Direct and indirect gene replacements in Aspergillus nidulans. Molecular Cellular Biology, v.5, p.1714$1721,1985$. 
MILLER, K.Y.; TOENNIS, T.M.; ADAMS, T.H.; MILLER, B.L. Isolation and transcriptional characterization of a morphological modifier the Aspergillus nidulans stunted (stuA) gene. Molecular and General Genetics, v.227, p.285-292, 1991.

MIMS, C.W.; RICHARDSON, E.A.; TIMBERLAKE, W.E. Ultrastructural analysis of conidiophore development in the fungus Aspergillus nidulans using freezesubstitution. Protoplasma, v.144, p.132-141, 1988.

MIRABITO, P.M.; OSMANI, S.A. Interactions between the developmental program and cell cycle regulation of Aspergillus nidulans. Seminars in Developmental Biology, v.5, p.139-145, 1994.

MIRABITO, P.M.; ADAMS, T.H.; TIMBERLAKE, W.E. Interactions of three sequentially expressed genes control temporal and spatial specificity in Aspergillus development. Cell, v.57, p.859-868, 1989.

MIZUUCHI, K. Transpositional recombination: Mechanistic insights from studies of $M u$ and other Elements. Annual Review Biochemistry, v.61, p.1011-1051, 1992.

MOLINA, M.G.M. Estudos de fenocópias em variantes com determinante de deterioração em Aspergillus nidulans. Piracicaba, 1993. 274p. (Mestrado - Escola Superior de Agricultura "Luiz de Queiroz" - Universidade de São Paulo.

MOMANY, M.; WESTFALL, P.J.; ABRAMOWSKY, G. Aspergillus nidulans swo mutants show defects in polarity establishment, polarity maintenance and hyphae morphogenesis. Genetics, v.151, p.557-567. 1999.

MONTEIRO, C.B. Avaliação da instabilidade mitótica de Aspergillus nidulans através de técnicas genéticas clássicas e fusão de protoplastos. Piracicaba, 1989. 135p. (Mestrado) - Escola Superior de Agricultura "Luiz de Queiroz" - Universidade de São Paulo.

MOONEY, J.L.; YAGER, L.N. Light is required of conidiation in Aspergillus nidulans. Genes and Development, v.4, p.1473-482, 1990.

MORPURGO, G. Research in Aspergillus nidulans genetics. Genetica, v.94, p.283-289, 1994.

MORPURGO, G. Somatic segregation induced by p-fluorophenylalanine. Aspergillus News Letter, v.2, p.10, 1961.

MORRIS, N.R. Mitotic mutants of Aspergillus nidulans. Genetical Research, v.26, p.237-254, 1976. 
MORRIS, N.R.; ENOS, A.P. Mitotic gold in a mold: Aspergillus genetics and the biology of mitosis. Trends in Genetics, v.8, p.32-37, 1992.

MORRIS, N.R.; XIANG, X.; BECKWITH, S.M. Nuclear migration advances in fungi. Trends Cellular Biology, v.5, p.278-282, 1995.

MORRIS, N.R.; OSMANI, S.; ENGLE, D.B.; DOONAN, J.H. The genetic analysis of mitosis in Aspergillus nidulans. Bioassays, v.10, p.196-201, 1989.

MORRIS, S.M.; ANAYA, P.; XIANG, X.; MORRIS, N.R.; MAY, G.S.; YU-LEE, L. A prolactin-inducible $\mathrm{T}$ cell gene product is structurally similar to the Aspergillus nidulans nuclear movement protein NUDC. Molecular Endocrinology, v.11, p.229236, 1997.

MOUYNA, I.; RENARD, J.L.; BRYGOO, Y. DNA polimorphism among Fusarium oxysporum $\mathrm{f}$. sp. elaeidis populations from oil palm, using a repeated and dispersed sequence "Palm". Current Genetics, v.30, p.174-180, 1996.

MUSACCHIO, A.; GIBSON, T.; RICE, P.; THOMPSON, J.; SARASTE, M. The PH domain: a common piece in the structural patchwork of signaling proteins. Trends in Biochemical Sciences, v.18, p.343-348, 1993.

NASMYTH, K. At the heart of the budding yeast cell cycle. Trends in Genetics, v.12, p.405-412, 1996.

NAVARRO, R.E.; STRINGER, M.A.; HANSBERG, W.; TIMBERLAKE, W.E.; AGUIRRE, J. catA, a new Aspergillus nidulans gene encoding a developmentally regulated catalase. Current Genetics, v.29, p.352-359, 1996.

NEWMEYER, D.; GALEAZZI, D.R. The instability of Neurospora duplication Dp (ILIR) H4250, and its genetic control. Genetics, v.85, p.461-487, 1977.

NGA, B.H.; ROPER, J.A. A system generation spontaneous intrachromosomal change a t mitosis in Aspergillus nidulans. Genetical Research, v.14, p.63-70, 1966.

NGA, B.H.; ROPER, J.A. Mitotic instability in duplication strains of Aspergillus nidulans: lethal deletions. Heredity, v.23, p.626-627, 1968b.

NGA, B.H.; ROPER, J.A. Quantitative intrachromosomal changes arising at mitosis in Aspergillus nidulans. Genetics, v.58, p.193-209, 1968a.

NIELSEN, M.L.; HERMANSEN, T.D.; ALEKESENKO, A. A family of DNA repeats in Aspergillus nidulans has assimilated degenerated retrotransposon. Molecular Genetics Genomics, v.265, p.883-887, 2001. 
NIFFINEGGER E SOUZA, D.R. Aspectos genéticos e citogenéticos da instabilidade mitótica em Aspergillus nidulans. Piracicaba, 1979. 244p. (Mestrado) - Escola Superior de Agricultura "Luiz de Queiroz" - Universidade de São Paulo.

NIGRO, C.L.; CHONG, C.S.; SMITH, A.C.; DOBYNS, W.B.; CARROZZO, R.; LEDBETTER, D.H. Point mutations and an intragenic deletion in LIS1, the lissencephaly causative gene in isolated lissencephaly sequence and Miller-Dieker syndrome. Human Molecular Genetics, v.6, p.157-164, 1997.

NISHIMURA, M.; HAYASHI, N.; JWA, N.S.; LAU, G.W.; HAMER, J.E. Insertion of the LINE retrotransposon MGL cause a conidiophore pattern mutation in Magnaporthe grisea. Molecular Plant-Microbe Interactions, v.13, p.892-894, 2000 .

NITTA, N.; FARMAN, M.L.; LEONG, S.A. Genome organization Magnaporthe grisea: integration of genetic maps, clustering of transposable elements and identification of genome duplications and rearrangements. Theoretical and Applied Genetics, v.95, p.20-32, 1997.

NURSE, P. Genetic control of cell size at cell division in yeast. Nature, v.256, p.457451, 1975.

NYYSSÖNEN, E.; AMUTAN, M.; ENFIELD, L.; STUBBS, J.; DUNN-COLEMAN, N.S. The transposable element Tan1 of Aspergillus niger var. awamori, a new member of the Fot1 family. Molecular and General Genetics, v.253, p.50-56, 1996.

O'CONNELL, C.E.; OSMANI, A.H.; MORRIS, N.R.; OSMANI, S.A. An extra copy of nimEcyclinB elvates pre-MPF level and partially suppresses mutation of nimTcdc 25 in Aspergillus nidulans. The EMBO Journal, v.11, p.2139-2149, 1992.

O'DONNELL, K.L.; OSMANI, A.H.; OSMANI, S.A.; MORRIS, N.R. bimA encodes a member of the tetratricopeptide repeat family of proteins and is required for the completion of mitosis in Aspergillus nidulans. Journal of Cell Science, v.99, p.711$719,1991$.

O'HARA, E.B.; TIMBERLAKE, W.E. Molecular characterization of the Aspergillus nidulans yA locus. Genetics, v.121, p.249-254, 1989.

OAKLEY, C.E.; OAKLEY, B.R. Identification of gamma-tubulin, a new member of the tubulin superfamily encoded by mipA gene of Aspergillus nidulans. Nature, v.338, p.662-664, 1989.

OAKLEY, B.R.; OAKLEY, C.E.; YOON, Y.; JUNG, K.M. Q-Tubulin is a component of the spindle pole body in Aspergillus nidulans. Cell, v.61, p.1289-1301, 1990. 
OLIVER, P.T. Conidiophore and spore developmental in Aspergillus nidulans. Journal of General Microbiology, v.73, p.45-54, 1972.

OSHEROV, N.; MAY, G.S. Conidial germination in Aspergillus nidulans requires RAS signaling and protein synthesis. Genetics, v.155, p.647-656, 2000.

OSHEROV, N.; MAY, G.S. The molecular mechanisms of conidial germination. FEMS Microbiology Letters, v. 199, p.153-160, 2001.

OSMANI, A.H.; OSMANI, S.A.; MORRIS, N.R. The molecular cloning and identification of a gene product specifically required for nuclear movement in Aspergillus nidulans. Journal of Cell Biology, v.111, p.543-551, 1990.

OSMANI, A.H.; VAN PEIJ, N.; MISCHKE, M.; O’CONNELL, M.J.; OSMANI, S. A single p34cdc2 protein kinase (encoded by nimXcdc2) is required at G1 and G2 in Aspergillus nidulans. Journal of Cell Science, v.107, p.1519- 1528, 1994.

OSMANI, S.A.; MIRABITO, P.M. The early impact of genetics on our understanding of cell cycle regulation in Aspergillus nidulans. Fungal Genetics and Biology, v.41, p.401-410, 2004.

OSMANI, S.A.; YE, X.S. Cell cycle regulation in Aspergillus by two protein kinases. Biochemical Journal, v.317, p.633-641, 1996.

OSMANI, S.A.; MAY, G.S.; MORRIS, N.R. Regulation of the mRNA levels of nimA, a gene required for the G2-M transition in Aspergillus nidulans. Journal of Cell Biology, v.104, p.1495-1504, 1987.

PACCOLA, L. Estudos genéticos e citogenéticos em variantes deteriorados de Aspergillus nidulans. Piracicaba, 1982. 131p. (Mestrado) - Escola Superior de Agricultura "Luiz de Queiroz" - Universidade de São Paulo.

PASCON, R.C. Análise genética, citológica e molecular de mutantes que afetam a morfogênese em Aspergillus nidulans. Piracicaba, 1998. 135p. (Doutorado) - Escola Superior de Agricultura "Luiz de Queiroz" - Universidade de São Paulo.

PASCON, R.C. Isolamento e caracterização de setores deteriorados da linhagem Abnc de Aspergillus nidulans. Piracicaba, 1994. 140p. (Mestrado) - Escola Superior de Agricultura "Luiz de Queiroz" - Universidade de São Paulo.

PASCON, R.C.; PIZZIRANI-KLEINER, A.A.; MILLER, B.L. The Aspergillus nidulans bncA1 mutation causes defects in the cell division cycle nuclear, movement and development morphogenesis. Molecular and General Genetics, v.264, p.546-554, 2001. 
PASTUSHOK, M.; AXELROD, D.E. Effect of glucose, ammonium and medium maintenance initiation by colonies of Aspergillus nidulans. Journal of General Microbiology, v.94, p.221-224, 1976.

PILAR, G.B.; BERNALES, M.; MENDIOLA, M.V.; La CRUZ, F. Single-stranded DNA intermediates in IS91 rolling-circle transposition. Molecular Microbiology, v.39, p.494-501, 2001.

PIZZIRANI-KLEINER, A.A.; AZEVEDO, J.L. Characterization and genetical analysis of an Aspergillus nidulans strain that produces mutinucleate conidia. Transaction of the British Mycological Society, v.86, p.123-130. 1986a.

PIZZIRANI-KLEINER, A.A.; AZEVEDO, J.L. Effect of the bncA gene on the instability of Aspergillus nidulans. Genetical Research, v.48, p.145-150, 1986 b.

PIZZIRANI-KLEINER, A.A.; PEREIRA, J.O.; AZEVEDO, J.L. Genética de Fungos Filamentosos. Série Fundamentos de Biotecnologia. Manaus: Editora da Universidade do Amazonas, 1998, 138p.

PONTECORVO, G. Non random distribution of multiple mitotic crossing-over among nuclei of heterozygous diploid Aspergillus. Nature, v.170, p.204, 1952.

PONTECORVO, G.; TAN-GLOOR, E; FORBES, E. Analysis of mitotic recombination in Aspergillus nidulans. Journal of Genetics, v.52, p.226-37, 1954.

PONTECORVO, G.; ROPER, J.A.; HEMMONS, L.M.; MacDONALD, K.D.; BUFTON, A.W.J. The genetics of Aspergillus nidulans. Advances in Genetics, v.5, p.141-238, 1953.

POULTER, R.M.; GOODWIN, T.J.D.; BUTLER, M.I. Vertebrete heletrons and other novel Helitrons. Gene, v.313, p.201-212, 2003.

PRADE, R.; TIMBERLAKE, W.E. The Aspergillus nidulans brlA regulatory locus consists of two overlapping transcription units that are individually required for conidiophore development. The EMBO Journal, v.12, p.2439-2447, 1993.

PU, R.T.; OSMANI, S.A. Mitotic destruction of the cell cycle regulated NIMA protein kinase of Aspergillus nidulans is required for mitotic exit. The EMBO Journal, v.14, p.995-1003, 1995.

QUEIROZ, M.V.; AZEVEDO, J.L. Characterization of an Aspergillus nidulans mutant with abnormal distribution of nuclei in hyphae, metulae, phialides and conidia. FEMS Microbiology Letters, v.166, p.49-55, 1998. 
QUEIROZ, M.V.; DABOUSSI, M.J. Impala, a tranposon from Fusarium oxysporum, is active tne genome of Penicillium griseoroseum. FEMS Microbiology Letters, v.218, p.317-321, 2003.

QUEIROZ, M.V.; PIZZIRANI-KLEINER, A.A.; AZEVEDO, J.L. Eletrophoretic characterization of Aspergillus nidulans strain with chromosomal duplication. Genetics and Molecular Biology, v.23, p.293-297, 2000.

RAEDER, U.; BRODA, P. Rapid preparation of DNA from filamentous fungi. Letters of Applied Microbiology, v.1, p.7-20, 1985.

RASMUSSEN, C.D.; MEANS, R.L.; LU, K.P.; MAY, G.S.; MEANS, A.R. Characterization and expression of the unique calmodulin gene Aspergillus nidulans. Journal of Biological, v.265, p.13767-13775, 1990.

REGALADO, C.M. Roles of calcium gradients in hyphal tip growth: a mathematical model. Microbiology, v.144, p.2771-2782, 1998.

REINER, O.; CARROZZO, R.; SHEN, Y.; WEHNERT, M.; FAUSTINELLA, F.; DOBYNS, W.B.; CASKEY, C.T.; LEDBETTER, D.H. Isolation of a Miller-Dieker lissencephaly gene containing $G$ protein L-subunit-like repeats. Nature, v.364, p.717-721, 1993.

RICE, W.R.; CHIPPINDALE, A.K. Sexual recombination and the power of natural selection. Science, v.294, p.555-559, 2001.

RICHTER, G.Y.; BJÖRKLÖF, F.; ROMANTSCHUK, M.; MILIS, D. Insertion specificity and trans-activation of IS801. Molecular General Genetics, v.5, p.381387, 1998.

ROBERTS, C.F. A replica plating technique for the isolation of nutritionally is exacting mutants of a filamentous fungus (Aspergillus nidulans). Journal of General Microbiology, v.20, p.540-48, 1959.

ROBINOW, C.F.; CATEN, C.E. Mitosis in Aspergillus nidulans. Journal of Cell Science, v.5, p.403-431, 1969.

ROBSON, G.D.; PREBBLE, E.; RICKERS, A.; HOSKING, S.; DENNING, D.W.; TRINCI, J.; ROBERTSON, W. Polarized growth of fungi hyphae is defined by an alkaline pH gradient. Fungal Genetics Biology, v.20, p.289-298, 1996.

ROCHA, C.L.M.S.C. Caracterização citológica, genética e molecular de um mutante para conidiogenese em Aspegillus nidulans. Piracicaba, 1997. 202p. (Doutorado) Escola Superior de Agricultura "Luiz de Queiroz" - Universidade de São Paulo. 
ROPER, J.A. Production of heterozygous diploids in filamentous fungi. Experientia, v.8, p.14-15, 1952.

ROSENBER, R.F.; KESSEL, M. Synchrony of nuclear replication in individual hyphae of Aspergillus nidulans. Journal of Bacteriology, v.94, p.1464-1471, 1967.

SALIM, K.; BOTTOMLEY, M.J.; QUERFURTH, E. Distinct specificity in the recognition of phospoinositides by the pleckstrin homology domains of dynamin and Bruton's tyrosine kinase. The EMBO Journal, v.15, p.6241-6250, 1996.

SAMBROOK, J.; FRISTCH; E.F.; MANIATIS, T. Molecular cloning: a laboratory manual. Cold Spring Harbor: Cold Spring Harbor Laboratory Press, 1989, v.3.

SANCHEZ-GARCIA, I.; RABBITTS, T.H. The LIM domain: a new structural motif found in zinc-finger-like proteins. Trends in Genetics, v.10, p.315-320, 1994.

SCHIER, N.; LIESE, R.; FISCHER, R. A Pcl-like cyclin of Aspergillus nidulans is transcriptionally activated by developmental regulators and is involved in sporulation. Molecular and Cellular Biology, v.21, p.4075-4088, 2001.

SCHMID-BERGER, N.; SCHMID, B.; BARTH, G. Ylt1, a highly repetitive retrotransposon in the genome of the dimorphic fungus Yarrowia lipolytica. Journal of Bacteriology, v.176, p.2477-2482, 1994.

SELKER, E.U. DNA methylation and chromatin structure: a view from below. Trends Biochemistry Science, v.15, p.103-107, 1990.

SELKER, E.U.; CAMBARERI, E.B.; JESEN, B.C.; HAACK, K.R. Rearrangement of duplicated DNA in specialized cells of Neurospora. Cell, v.51, p.741-752, 1987.

SEWALL, T.C.; MIMS, C.W.; TIMBERLAKE, W.E. aba A control phialides differentiation in Aspergillus nidulans. Plant Cell, v.2, p.731-739, 1990.

SHAW, B.D.; MOMANY, C.; MOMANY, M. Aspergillus nidulans swoF encodes an Nmyristoyl Trasnsferase. Eukaryotic Cell, v.1, p.241-248, 2002.

SHI, X.; SHA, Y.; KAMINSKYJ, S.G.W. Aspergillus nidulans hypA regulates morphogenesis through the secretion pathway. Fungal Genetics and Biology, v.41, p.75-88, 2004.

SIEVERS, N.; BERTSCH, E.; FISCHER, R. Isolation of nuclear migration mutants of Aspergillus nidulans using GFP expressing strains. Mycological Research, v.103, p.961-966, 1999. 
SONE, T.; SUTO, M.; TOMITA, F. Host species-specific repetitive DNA sequence in the genome of Magnaporthe grisea, the rice blast fungus. Biotechnology Biochemistry, v.57, p.1228-1230, 1993.

STAHL, U.; TUDZYNSKI, P. Molecular biology of filamentous fungi. Weinheim; New York, ACADEMIC Press, 1992, p.276.

SUELMANN, R.; SIEVERS, N.; FISCHER, R. Nuclear traffic in fungal hyphae: In vivo study of nuclear migration and positioning in Aspergillus nidulans. Molecular Microbiology, v. 25, p. 757-769, 1997.

SUELMANN, R.; SIEVERS, N.; GALETZKA, D.; ROBERTSON, L.; TIMBERLAKE, W.E.; FISCHER, R. Increased nuclear traffic chaos in hyphae of apsB mutants of Aspergillus nidulans: Molecular characterization of apsB and "in vivo" observation of nuclear behavior. Molecular Microbiology, v. 30, p. 831-842, 1998.

TAMAME, M.; SANTOS, E. Demonstration of 5 methyl cytosine occurrence in the genome of Aspergillus nidulans. Cellular Biochemistry, v. 13, p. 214, 1988.

TAMAME, M.; ANTIQUERA, F.; VILLANUEVA, J.R.; SANTOS, T. High-frequency conversion o a "fluffy" developmental phenotype in Aspergillus nidulans by 5azacytidine treatment: evidence for involvement of a single nuclear gene. Molecular and Cellular Biology, v. 3, p. 2287-2297, 1983.

TAVAKOLI, N.; COMANDUCCI, A.; DODD, H.M.; LETT, M.C.; ALBIGER, B.; BENNET, P. IS1294, a DNA element that transposes by RC transposition. Plasmid, v. 44, p. 66-84, 2000.

TIMBERLAKE, W.E. Molecular genetics of Aspergillus nidulans development. Annual Review of Genetics, v. 24, p. 5-36, 1990.

TIMBERLAKE, W.E.; CLUTTERBUCK, A.J. Genetic Regulation of Conidiation. In: MARTINELLI, S.D.; KINGHORN, J.R. Aspergillus 50 years on. 1994. v. 29, cap. 16, p.383-427.

TOSA, Y.; NAKAYASHIKI, H.; HYODO, H.; MAYAMA, S.; KATO, H.; LEONG, S.A. Distribution of retrotransposon MAGGY in Pyricularia species. Annual Phytopathology Society Japan, v. 61, p. 549-554, 1995.

VALENTE, B.; CHUMLEY, F.G. Molecular genetic analysis of the rice blast fungus, Magnaporthe grisea. Annual Review Phytopathology, v. 29, p. 443-467, 1991.

VIERULA, P.J.; MAIS, J.M. A gene required for nuclear migration in Neurospora crassa codes for a protein with cysteine-rich, LIM/RING-like domains. Molecular Microbiology, v. 24, p. 331-340, 1997. 
VOYTAS, D.F.; CUMMINGS, M.P.; KONICZNY, A.; AUSUBEL, F.M.; RODERMEL, S.R. Copia-like retrotransposon are ubiquitous among plants. Proceedings of the National Academy of Sciences USA, v. 89, p. 7124-4128, 1992.

WESSEL, J.G.H. Cell wall synthesis in apice hyphal growth. International Review of Cytology, v. 104, p. 37-79, 1986.

WIESER, J.; LEE, B.N.; FONDON, J.W.; ADAMS, T.H. Genetic requirements for initiating asexual development in Aspergillus nidulans. Current Genetics, v. 27, p. 62-69, 1994.

WILSON, R.A.; CHANG, P.K.; DOBRZYN, A.; NTAMBI, J.M.; ZARNOWSKI, R.; KELLER, N.P. Two $\Delta 9$-steric acid desaturases are required for Aspergillus nidulans growth and development. Fungal Genetics and Biology, v. 41, p. 501-509, 2004.

WINDHOFER, F.; CATCHESIDE, D.E.A.; KEMPKEN, F. Methylation of the foreign transposon Restless in vegetative mycelia of Neurospora crassa. Current Genetics, v. 37, p.194-199, 2000.

WOLKOW, T.D.; HARRIS, S.D.; HAMER, J.E. Cytokinesis in Aspergillus nidulans is controlled by cell size, nuclear position and mitosis. Journal of Cell Science, v. 109, p. 2179-2188, 1996.

WU, L.; OSMANI, S.A.; MIRABITO, P.M. A role for NIMA in nuclear localization of cyclin B in Aspergillus nidulans. The Journal of Cell Biology, v. 141, p. 1575$1587,1998$.

XIANG, X.; MORRIS, N.R. Hyphal tip growth and nuclear migration. Current Opinion in Microbiology, v. 2, p.636-640, 1999.

XIANG, X.; BECKWITH, S.M.; MORRIS, N.R. Cytoplasmic dynein is involved in nuclear migration in Aspergillus nidulans. Proceedings of the National Academy of Sciences USA, v.91, p.2100-2104, 1994

XIANG, X.; ROGHI, C.; MORRIS, N.R. Characterization and localization of the cytoplasmic dynein heavy chain in Aspergillus nidulans. Proceedings of the National Academy of Sciences USA, v.92, p.9890-9894, 1995 b.

XIANG, X.; OSMANI, A.H.; OSMANI, S.A.; XIN, M.; MORRIS, N.R. nudF, a nuclear migration gene in Aspergillus nidulans, is similar to the human LIS-1 gene required for neuronal migration. Molecular and Biology of the Cell, v.6, p.297-310, 1995 a. 
XIONG, M.; CHEN, H.J.; PRADE, R.A.; WANG, Y.; GRIFFITH, J. On the consistency of phisical mapping method to reconstruct in vitro. Genetics, v.142, p.267-284, 1996.

YAGER, L.N. Early developmental events during asexual and sexual sporulation in Aspergillus nidulans. In.: BENNETT, J.W.; KLEIN, M.A. Aspergillus: Biology and Industrial Applications. Slonehom, Butterwourth - Heinemann, 1982. p.19-41.

YE, X.S.; LEE, S.L.; WOLKOW, T.D.; McGUIRE, S.L.; HAMER, J.E.; WOOD, G.C.; OSMANI, S.A. Interaction between development and cell cycle regulators is required for morphogenesis in Aspergillus nidulans. The EMBO Journal, v.18, p.6994-7001, 1999.

YE, X.S.; XU, G.; PU, R.T.; FINCHER, R.R.; OSMANI, A.H.; OSMANI, S.A. Analysis of cell cycle regulation using Aspergillus nidulans. Canadian Journal Botany, v.73, p.359-363, 1995.

YEADON, P.J.; CATCHESIDE, D.E. Guest: a 98 bp inverted repeat transposable element in Neurospora crassa. Molecular and General Genetics, v.247, p.105-109, 1995.

YU, J.H.; WIESER, J.; ADAMS, T.H. The Aspergillus FlbA RGS domain protein antagonizes G-protein signaling to block proliferation and allow development. The EMBO Journal, v.15, p.5184-5190, 1996.

ZEYL, C.; BELL, G. Symbiotic DNA in the eukaryotic genome. Trends in Ecology and Evolution, v.11, p.10-15, 1996.

ZEYL, C.; BELL, G. The advantage of sex in evolving yeast population. Nature, v.388, p.465-468, 1997.

ZEYL, C.; BELL, G.; GREEN, D.M. Sex and the spread of retrotransposon Ty3 in experimental population of Saccharomyces cerevisiae. Genetics, v.143, p.1567$1557,1996$. 


\section{APÊNDICE}



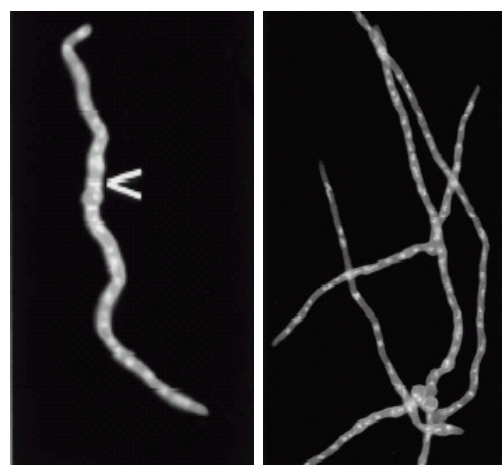

Mutantes sep, Harris, S. Genetics, v. 148, p. 1055 - 1067, 1998.
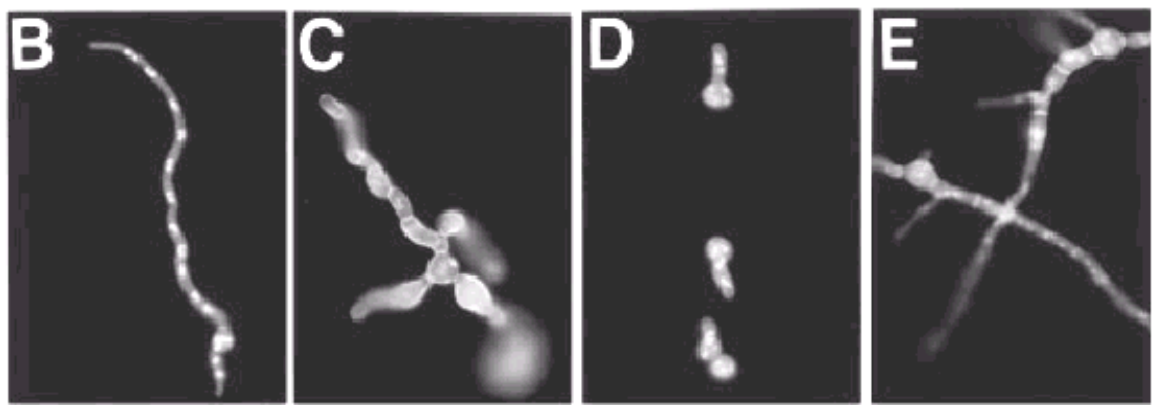

Mutantes pod, Harris, S. Genetics, v. 151, p. 1015 - 1025, 1999.

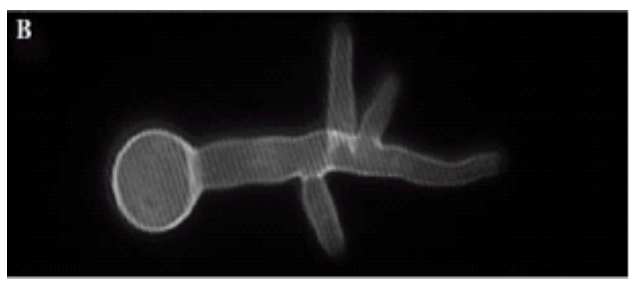

Mutantes rho, Guest, G. Fungal and Genetics Biology, v. 41, p. 13-22, 2004.

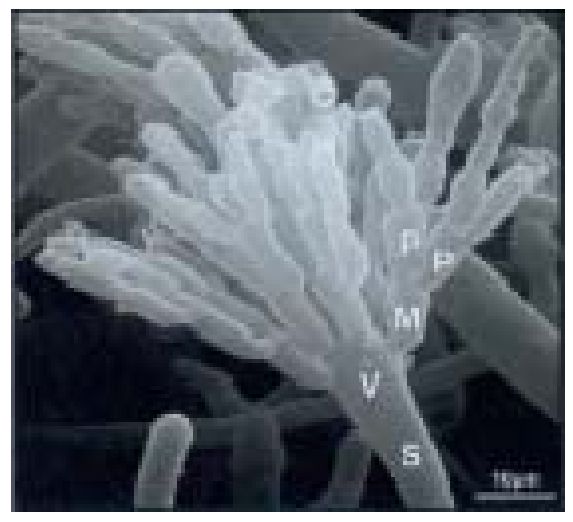

Mutante brl brando. Adams, Microbiology and Molecular Biology Reviews, v. 62, p. 35 - 54, 1998. 